\title{
Detailed Study of Selenium and Other Constituents in Water, Bottom Sediment, Soil, Alfalfa, and Biota Associated with Irrigation Drainage in the Uncompahgre Project Area and in the Grand Valley, West-Central Colorado, 1991-93
}

by David L. Butler, Winfield G. Wright, and Kathleen C. Stewart, U.S. Geological Survey

Barbara Campbell Osmundson and Richard P. Krueger,

U.S. Fish and Wildlife Service, and

Daniel W. Crabtree, Bureau of Reclamation

\section{U.S. GEOLOGICAL SURVEY}

Water-Resources Investigations Report 96-4138

U.S. GEOLOGICAL SURVEY

U.S. FISH AND WILDLIFE SERVICE

BUREAU OF RECLAMATION

BUREAU OF INDIAN AFFAIRS 


\title{
U.S. DEPARTMENT OF THE INTERIOR BRUCE BABBITT, Secretary
}

\author{
U.S. GEOLOGICAL SURVEY
}

Gordon P. Eaton, Director

The use of firm, trade, and brand names in this report is for identification purposes only and does not constitute endorsement by the U.S. Geological Survey.

For additional information write to:

Copies of this report can be purchased from:

District Chief

U.S. Geological Survey

Box 25046, Mail Stop 415

Denver Federal Center

Denver, CO 80225-0046
U.S. Geological Survey

Branch of Information Services

Box 25286

Denver, CO 80225-0286 


\section{CONTENTS}

Abstract.

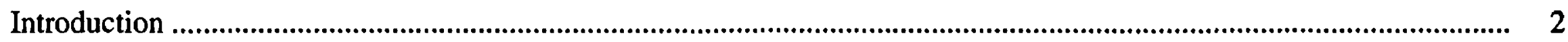

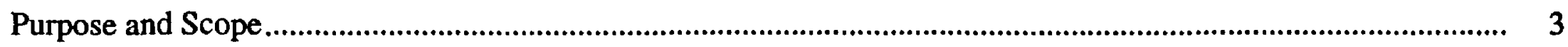

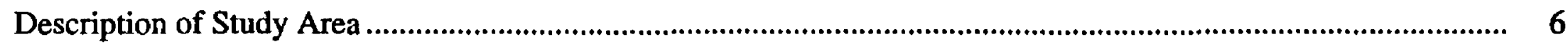

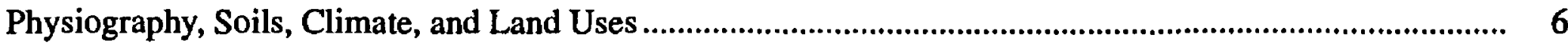

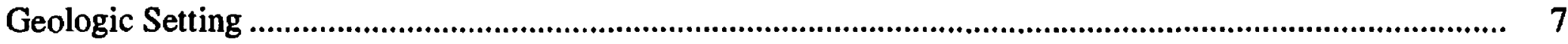

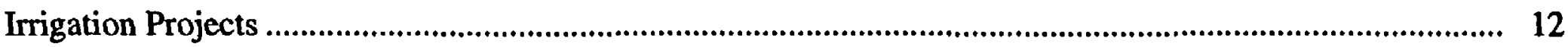

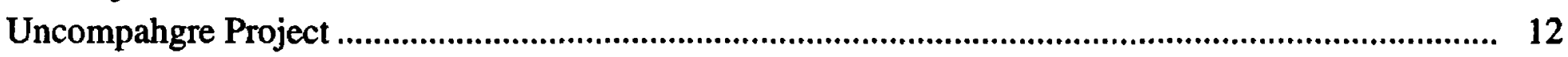

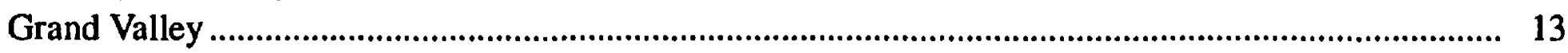

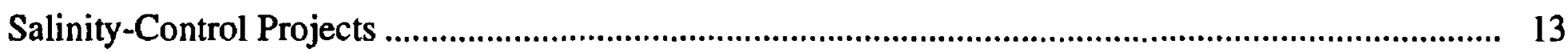

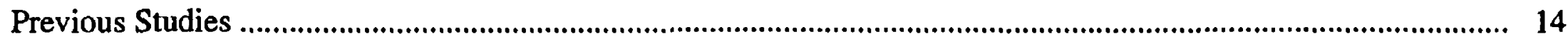

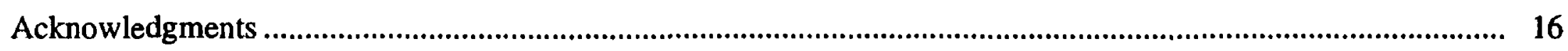

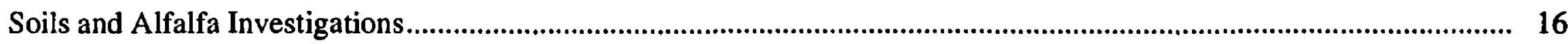

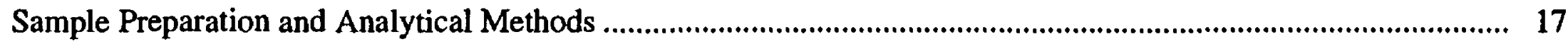

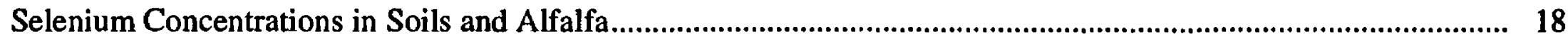

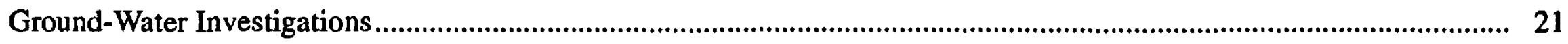

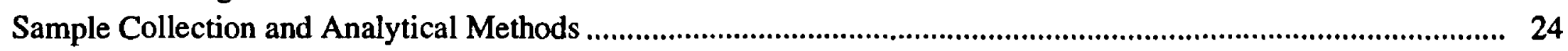

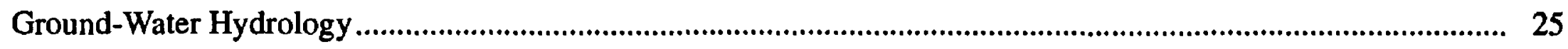

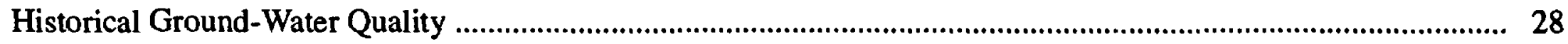

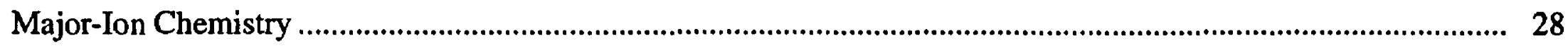

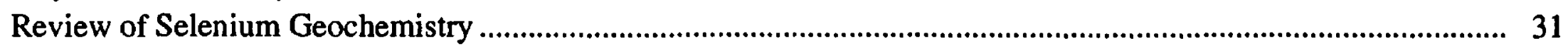

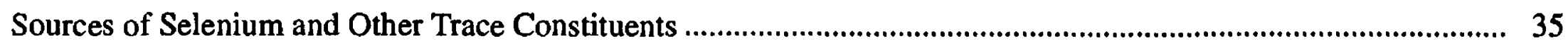

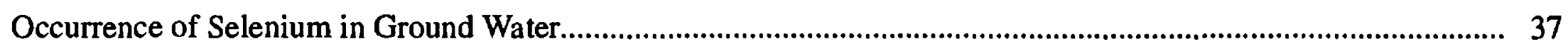

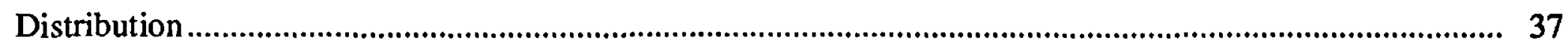

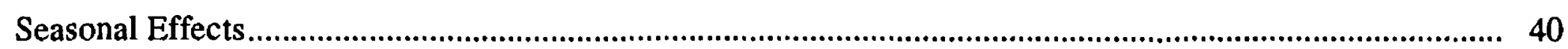

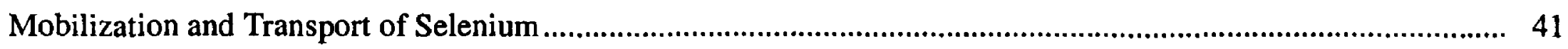

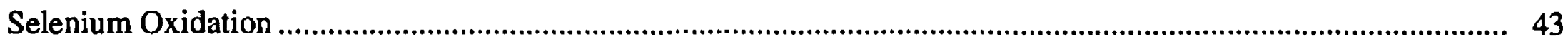

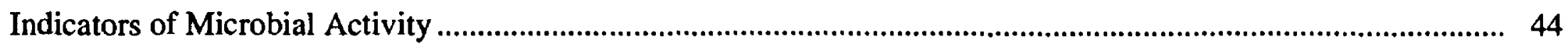

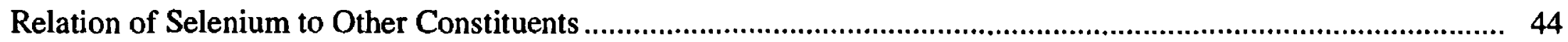

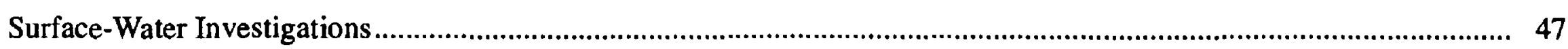

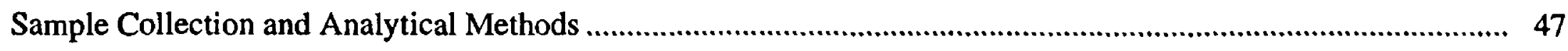

Selenium Concentrations and Loads in the Gunnison and Colorado Rivers................................................48

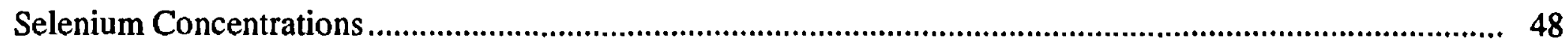

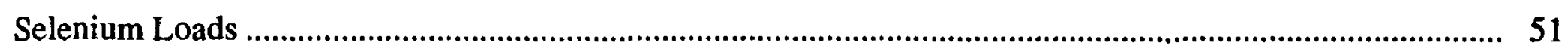

Distribution, Magnitude, and Variation of Selenium Concentrations .............................................................. 54

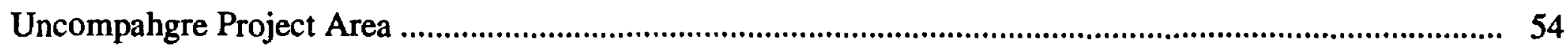

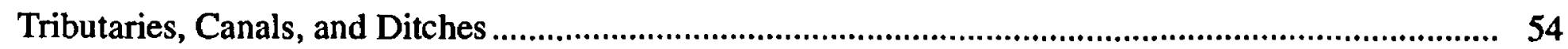

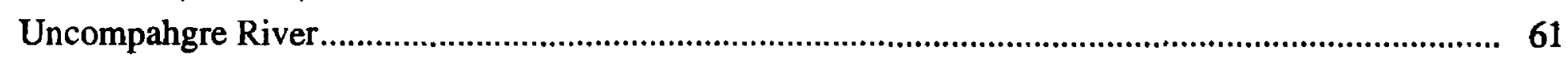

Adjacent Areas in the Lower Gunnison River Basin ............................................................ 61

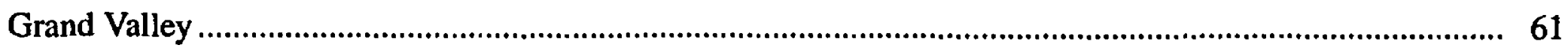

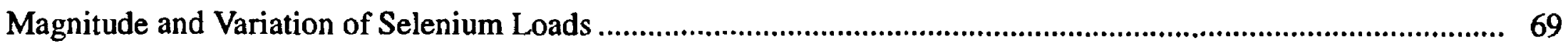

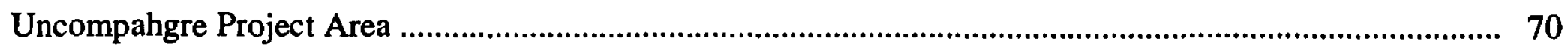

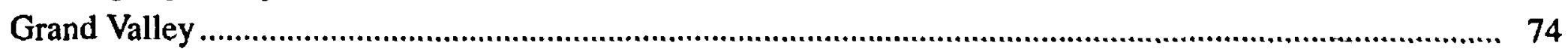


Dissolved Solids and Major Constituents and Relations to Selenium ......................................................... 77

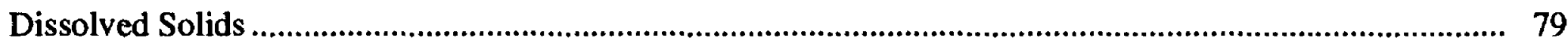

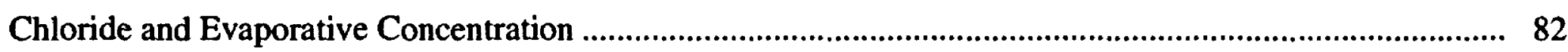

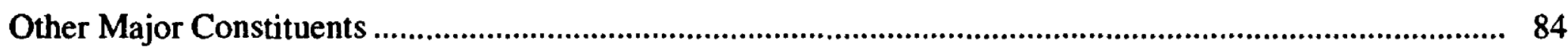

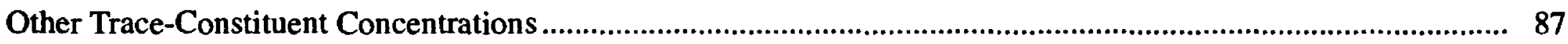

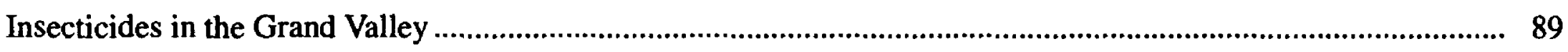

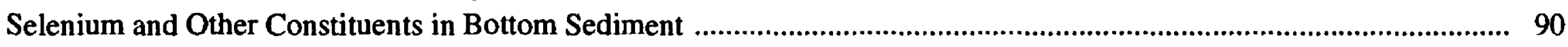

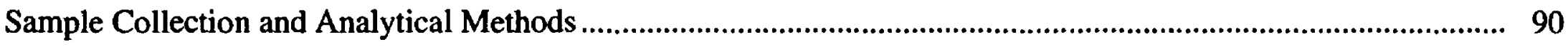

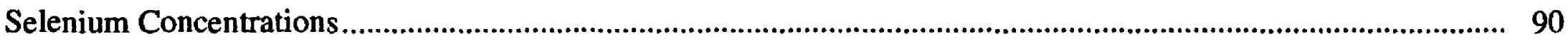

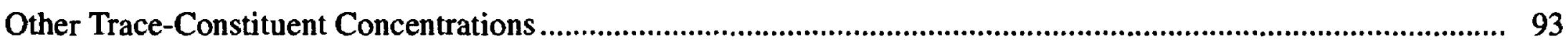

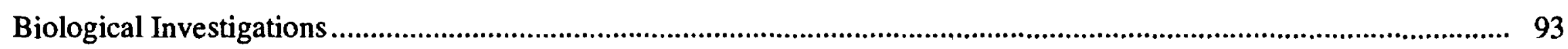

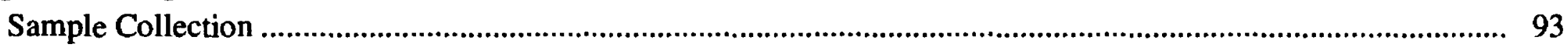

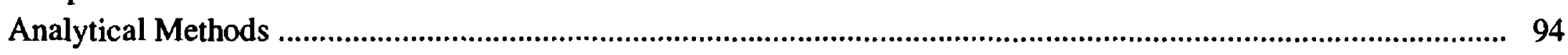

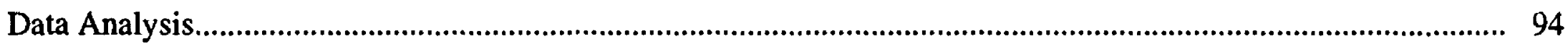

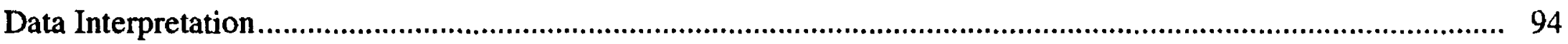

Selenium Concentrations in Fish Samples and Their Food Items in Irrigated Areas ............................................ 95

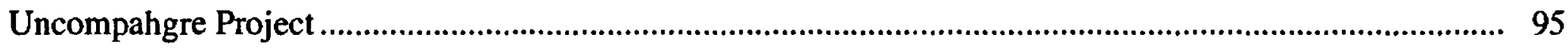

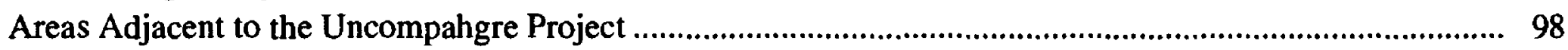

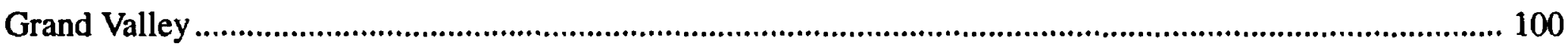

Selenium Concentrations in Fish Samples from Mainstem Rivers ................................................................ 104

Risk Assessment for Endangered Fish from Selenate and Selenite .................................................................. 107

Other Trace-Constituent Concentrations in Fish Tissues and Fish Food Items in Irrigated Areas ............................. 108

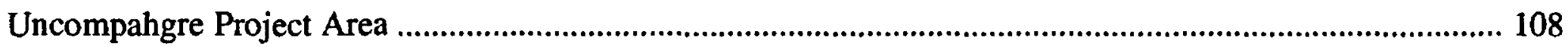

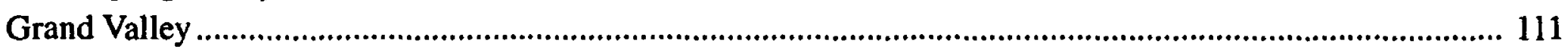

Other Trace-Constituent Concentrations in Fish Tissues and Fish Food Items from Mainstem Rivers .................... 112

Risk Assessment for Endangered Fish from Four Trace Constituents .......................................................... 113

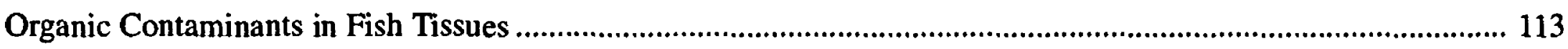

Selenium Concentrations in Migratory Birds and Their Food Items ............................................................... 115

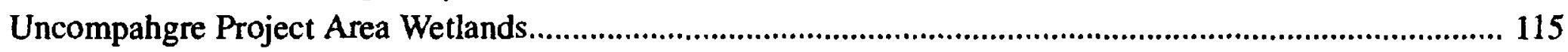

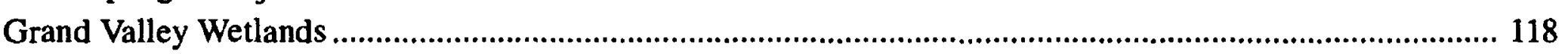

Other Trace-Constituent Concentrations in Birds and Their Food Items ......................................................... 118

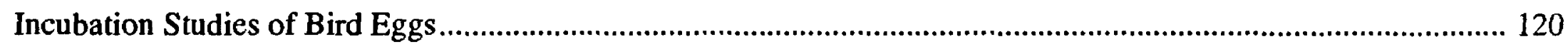

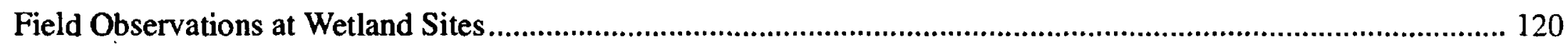

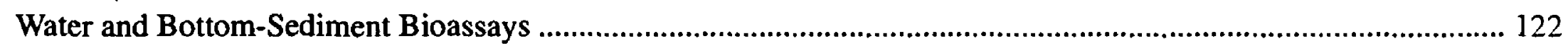

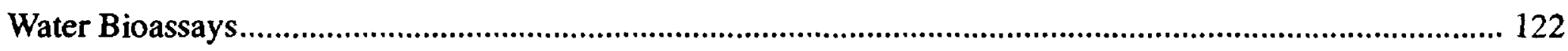

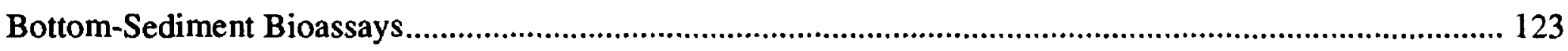

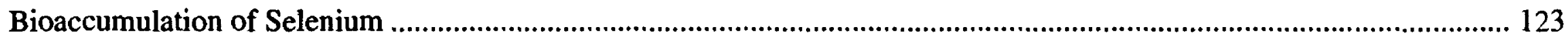

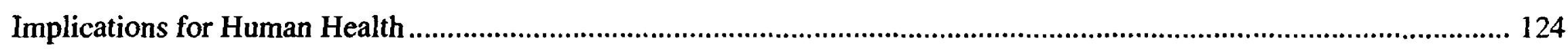

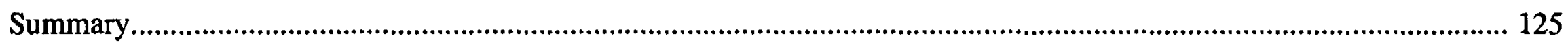

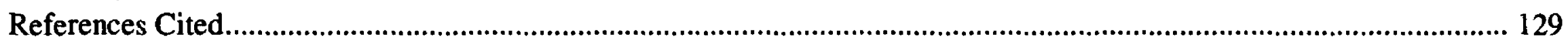

FIGURES

1-6. Maps showing:

1. Location of the Uncompahgre Project area, the Grand Valley, and selected water-sampling sites on major streams

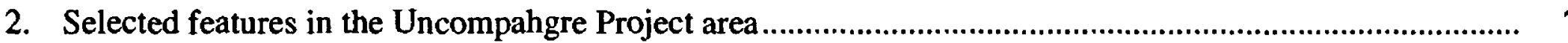

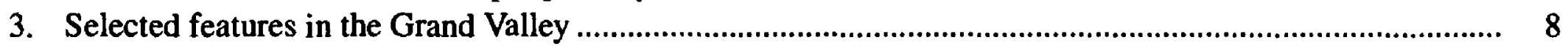

4. Generalized surficial geology of the Uncompahgre Project ................................................................ 9 
5. Grand Valley geology: $(A)$ surficial geology, $(B)$ generalized extent of the cobble aquifer, and

(C) generalized geologic section

6. Distribution of soil-sampling sites within townships in irrigated areas of the Uncompahgre Project ........... 17

7. Graph showing percent of variance in selenium concentrations in soils and alfalfa for different levels in the sampling design.

8. Map showing locations of type areas and locations of wells and springs in the Uncompahgre Project area where samples were collected for chemical analysis

9. Map showing location of type area and wells in the Grand Valley where samples were collected for chemical analysis.

10. Schematic showing hydrogeologic setting and ground-water flow in $(A)$ Reed Wash type area and

$(B)$ Dry Creek type area.

11. Graph showing water-level altitude and specific conductance of water in well 143N0, Grand Valley, March 1992-March 1993

12. Graphs showing historical water-level altitudes and dissolved-solids concentrations in water from wells $125 \mathrm{Q} 5$ and 208K0 located in the Grand Valley

13. Trilinear diagram showing percentages of major ions in water from selected wells during the irrigation season in the Uncompahgre Project area and in the Grand Valley...

14. Graphs showing oxygen and hydrogen stable isotope values in water from selected wells, streams, and rivers in the Uncompahgre Project area and in the Grand Valley.

15. Stability-field diagram for selenium species in natural waters and data points calculated from seleniumspeciation data collected for this study

16. Schematic showing conceptual model of the occurrence of selenium in Mancos Shale, shale residuum, alluvium, and ground water in the Uncompahgre Project area and in the Grand Valley

17. Graph showing platinum-electrode potential and concentrations of dissolved selenium in water from wells in Mancos Shale residuum.

18. Graph showing dissolved selenium in water from wells in shale residuum and alluvium during the irrigation season and nonirrigation season.

19. Graphs showing correlation of dissolved solids and dissolved selenium in water from wells in alluvium and shale residuum

20. Scanning-electron photomicrograph of framboidal pyrite collected on 0.45 -micrometer water-filter paper from a well located outside the irrigated Grand Valley area, October 1991

21. Graphs showing correlations of dissolved selenium with various dissolved constituents in water from wells in the Uncompahgre Project area and in the Grand Valley

22. Graph showing dissolved-selenium concentrations and the LOWESS smoothed curves of selenium concentrations for the Gunnison River at Whitewater and the Colorado River near the Colorado-Utah State line, 1975-92.

23. Schematic diagram showing the lower Gunnison River Basin and relative locations of selected surface-

24. Graph showing selenium loads in the Gunnison River at Whitewater and the Colorado River near the

Colorado-Utah State line, July 1991-August 1992, and the residual loads.

25. Schematic diagram showing the southern part of the Uncompahgre Project, relative locations of surfacewater-sampling sites, and selenium concentrations in samples collected during synoptic surveys, January-March 1992

26. Schematic diagram showing the northern part of the Uncompahgre Project, relative locations of surfacewater-sampling sites, and selenium concentrations in samples collected during synoptic surveys, January-March 1992

27-29. Graphs showing:

27. Selenium concentrations in samples from Dry Creek at site DRY1, Cedar Creek at site CD1, Loutsenhizer Arroyo at sites LZAM and LZA1, and an unnamed drainage at site RD1, July 1991-August 1992

28. Selenium concentrations in the Uncompahgre River at Delta, 1987-92.

29. Selenium concentrations in the Uncompahgre River, February 19-20, 1992 
30. Schematic diagram showing the western part of the Grand Valley, relative locations of surfacewater-sampling sites, and selenium concentrations in samples collected during synoptic surveys, February-March 1992

31. Schematic diagram showing the eastern part of the Grand Valley, relative locations of surfacewater-sampling sites, and selenium concentrations in samples collected during synoptic surveys, February-March 1992

32-43. Graphs showing:

32. Mean selenium concentrations in irrigation-drainage samples collected in March 1991 and in

February and March 1992 at the 20 reconnaissance sites in the Grand Valley.

33. Selenium concentrations in samples from Salt Creek at site SC, Reed Wash at site RW1, and Leach Creek at site LC1, March 1991-August 1992.

34. Selenium loads in the Uncompahgre River, February 19-20, 1992

35. Seasonally weighted mean selenium loads for 12 sites in the Uncompahgre Project, 1991-92

36. Mean selenium loads of three sets of samples collected in 1991-92 for 20 sites in the Grand Valley.

37. Selenium loads in Salt Creek at site SC, Reed Wash at site RW1, Big Salt Wash at site BSW1, and Leach Creek at site LC1, March 1991-August 1992

38. Relation of seasonally weighted mean selenium load to drainage-basin area within the irrigated area for 20 basins in the Grand Valley

39. Relations of selenium concentration to specific conductance for Loutsenhizer Arroyo and Reed Wash.

40. Relations of selenium load to dissolved-solids load for Loutsenhizer Arroyo (site LZA1) and Reed Wash (site RW1)

41. Relation of estimated selenium yield based on sampling during 1991-92 to estimates of dissolved-solids yield by the Bureau of Reclamation for 15 basins in the Grand Valley

42. Selenium and chloride concentrations in irrigation-drainage samples from the Grand Valley, November 1991-March 1992, and the estimated evaporative-concentration line.

43. Relations of selenium to nitrite-plus-nitrate concentrations in water samples collected during the nonirrigation season from streams and ditches on the eastern side of the Uncompahgre Project and in the Grand Valley north of the Colorado River, 1991-92

44-47. Maps showing:

44. Location of 1991 biota sampling sites on tributary streams in the Uncompahgre Project 96

45. Location of 1991 biota sampling sites adjacent to the Uncompahgre Project

46. Location of 1991 biota sampling sites on tributary streams in the Grand Valley

47. Location of sampling sites on major rivers where fish samples were collected in 1992

48-51. Graphs showing:

48. Mean selenium concentrations in four fish-trophic groups in the Colorado, North Fork of the Gunnison, Gunnison, and Uncompahgre Rivers

49. Mean selenium concentrations in three fish-trophic groups collected from four sites on the Colorado River.

50. Mean selenium concentrations in three fish-trophic groups collected from four sites in the Gunnison River Basin

51. Mean selenium concentrations in three fish-trophic groups collected from three sites on the Uncompahgre River

52. Map showing location of sampling sites at wetlands in the Uncompahgre Project area

53. Map showing location of sampling sites at wetlands in the Grand Valley.

\section{TABLES}

1. Distribution of soil-sampling sites by geologic units in townships of the Uncompahgre Project area

2. Geometric mean and observed range of total- and water-extractable selenium concentrations in soil and total-selenium concentrations in alfalfa for all samples from the Uncompahgre Project area, by geologic unit. 
3. Geometric mean concentrations of arsenic, molybdenum, uranium, and zinc in soils from alluvium overlying Mancos Shale in the Uncompahgre Project area and in soils from the Western United States

4. Hydrogeologic settings of the ground-water-flow systems affected by irrigation in the Uncompahgre Project area and in the Grand Valley.

. Results of thermodynamic speciation calculations for water from wells in the Uncompahgre Project area and from the Grand Valley.

Evaporite mineral species and salt efflorescence associated with the Mancos Shale and shale residuum in the Grand Valley

7. Semiquantitative clay and bulk mineralogy of Mancos Shale bedrock core, shale residuum, alluvium, and ground-water-filter residuum.

8. Element and organic-carbon concentrations in soil and rock samples from the Uncompahgre Project area and from the Grand Valley....

. Geochemical environments of the ground-water-flow systems, hydrogeologic settings, and ranges of dissolved-selenium concentrations in Mancos Shale residuum and alluvium in the irrigated Uncompahgre Project area and in the Grand Valley .

. Concentrations of dissolved redox-active constituents, water properties, and hydrogeologic setting of water from wells in alluvium and shale residuum in the Uncompahgre Project area and in the Grand Valley.

11. Speciation of dissolved selenium in selected ground-water samples from the Uncompahgre Project area and from the Grand Valley.

Speciation of extractable selenium in alluvial-aquifer-sediment samples from the Grand Valley.

13. Energies of reaction for oxidation of selenium by oxygen and nitrate.

14. Sulfur-isotope data for water from selected wells in shale residuum and alluvium...

15. Summary of selenium concentrations in the Gunnison and Colorado Rivers and Plateau Creek and the number of samples exceeding aquatic-life criteria of the U.S. Environmental Protection Agency.....

6. Summary of selenium concentrations in irrigated areas of the Uncompahgre Project in 1991-92 and the number of samples that exceeded aquatic-life criteria of the U.S. Environmental Protection Agency .

17. Summary of selenium concentrations in samples collected during the synoptic surveys of the Uncompahgre Project, January through March 1992.

18. Summary of selenium concentrations in irrigated areas in the Grand Valley and the number of samples that exceeded aquatic-life criteria of the U.S. Environmental Protection Agency...

19. Summary of selenium concentrations in samples collected during the synoptic surveys of the Grand Valley, February and March 1992.

20. Concentrations of dissolved selenium, selenate, and selenite in water samples collected from five streams in the Grand Valley, March 24, 1992.

1. Pearson correlation coefficients of selenium concentration to specific conductance and to dissolved-solids, major-ion, boron, and uranium concentrations for the Uncompahgre Project and the Grand Valley .....

22. Summary of dissolved trace-constituent concentrations in surface-water samples from the Uncompahgre

23. Concentrations of selenium, uranium, total carbon, and organic carbon in bottom-sediment, salt-crust, and soil samples

24. Concentrations of total, soluble, and adsorbed selenium and the percent selenite in bottom-sediment samples from eight streams, March 1992

25. Statistical summary of selenium concentrations in selected biota samples collected in 1991 in the Uncompahgre Project area.

Number of whole-body fish samples collected in the Uncompahgre Project area that exceeded the 1984 National Contaminant Biomonitoring Program 85th-percentile concentrations for seven trace constituents

27. Statistical summary of selenium concentrations in selected biota samples collected during 1991 from the Grand Valley

28. Number of whole-body fish samples collected in the Grand Valley that exceeded the 1984 National Contaminant Biomonitoring Program 85th-percentile concentrations for seven trace constituents .. 
29. Number of whole-body fish samples collected in 1992 from the Colorado, North Fork of the Gunnison, Gunnison, and Uncompahgre Rivers that exceeded the 1984 National Contaminant Biomonitoring Program 85th-percentile concentrations for seven trace constituents. 107

30. Concentrations of selenate and selenite selenium causing acute toxicity to Colorado squawfish and razorback suckers

31. Hazard assessment of selenate and selenite selenium in water samples collected in March 1992 from five streams in the Grand Valley to three life stages of Colorado squawfish and razorback suckers.

32. Concentrations of boron, uranium, vanadium, and zinc causing acute toxicity to Colorado squawfish and razorback suckers

33. Hazard assessment of boron and uranium in water samples collected from five streams in the Grand Valley to three life stages of Colorado squawfish and razorback suckers

34. Hazard assessment of vanadium and zinc in water samples collected from five streams in the Grand Valley to three life stages of Colorado squawfish and razorback suckers.

35. Geometric mean and maximum concentrations of the 1984 National Contaminant Biomonitoring Program for selected organochlorine pesticides and polychlorinated biphenyls

36. Statistical summary of selenium concentrations in selected bird-food and bird-tissue samples collected during 1991-92 from wetlands in the Uncompahgre Project, wetlands adjacent to the Uncompahgre Project, and wetlands in the Grand Valley

37. Geometric mean selenium concentrations in water, bottom-sediment, and biota samples from wetlands in the Uncompahgre Project, wetlands adjacent to the Uncompahgre Project, and wetlands in the Grand Valley

38. Selenium concentrations in fish-fillet and bird-breast samples from the Uncompahgre Project area and the Grand Valley, and the quantity of each sample that could be consumed without exceeding the maximum recommended daily quantity for an adult human 


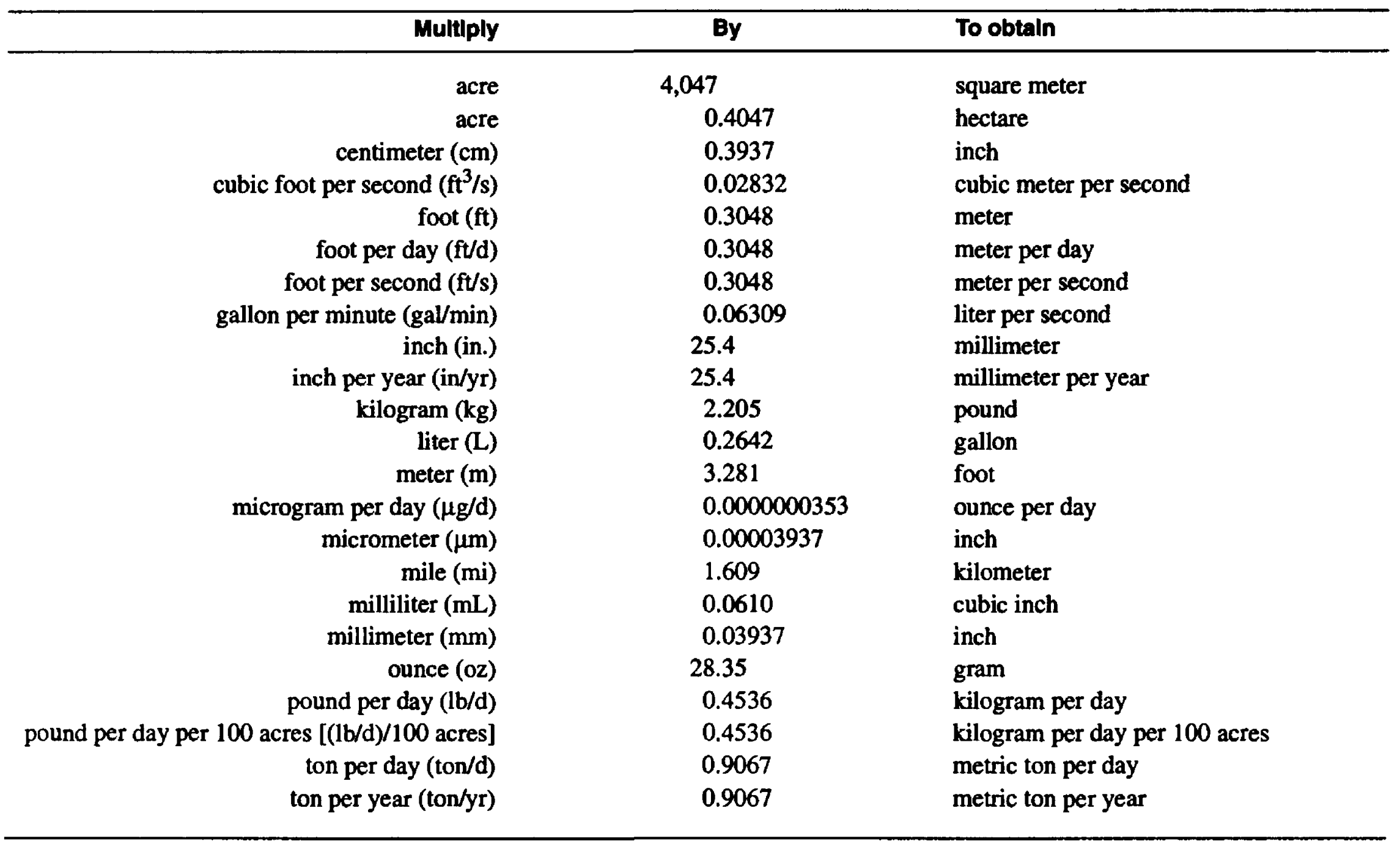

Degree Celsius $\left({ }^{\circ} \mathrm{C}\right)$ may be converted to degree Fahrenheit $\left({ }^{\circ} \mathrm{F}\right)$ by using the following equation:

$$
{ }^{\circ} \mathrm{F}=9 / 5^{\circ} \mathrm{C}+32
$$

Degree Fahrenheit $\left({ }^{\circ} \mathrm{F}\right)$ may be converted to degree Celsius $\left({ }^{\circ} \mathrm{C}\right)$ by using the following equation:

$$
{ }^{\circ} \mathrm{C}=5 / 9\left({ }^{\circ} \mathrm{F}-32\right)
$$

The following terms and abbreviations also are used in this report:

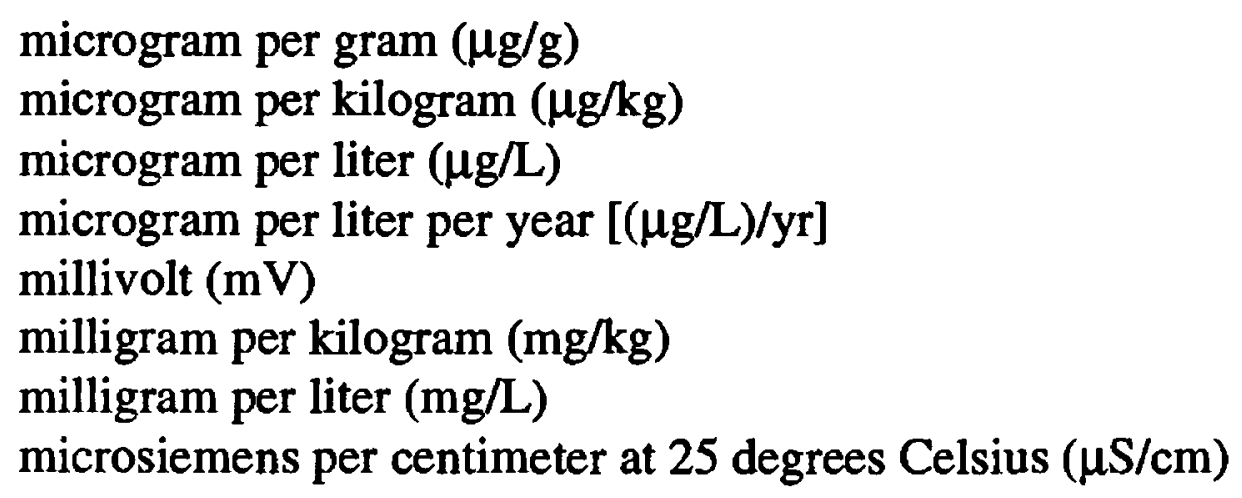

Sea level: In this report, "sea level" refers to the National Geodetic Vertical Datum of 1929 (NGVD of 1929)-a geodetic datum derived from a general adjustment of the first-order level nets of both the United States and Canada, formerly called Sea Level Datum of 1929.

For those who wish to convert dry-weight concentrations to wet-weight concentrations for biological samples, the equation is:

$$
\text { wet } \text { weight }=\text { dry weight }[1-(\text { percent moisture/100) }]
$$




\title{
Detailed Study of Selenium and Other Constituents in Water, Bottom Sediment, Soil, Alfalfa, and Biota Associated with Irrigation Drainage in the Uncompahgre Project Area and in the Grand Valley, West-Central Colorado, 1991-93
}

\author{
by David L. Butler, Winfield G. Wright, Kathleen C. Stewart, Barbara Campbell Osmundson, \\ Richard P. Krueger, andDaniel W. Crabtree
}

\section{Abstract}

In 1985, the U.S. Department of the Interior began a program to study the effects of irrigation drainage in the Western United States. These studies were done to determine whether irrigation drainage was causing problems related to human health, water quality, and fish and wildlife resources. Results of a study in 1991-93 of irrigation drainage associated with the Uncompahgre Project area, located in the lower Gunnison River Basin, and of the Grand Valley, located along the Colorado River, are described in this report. The focus of the report is on the sources, distribution, movement, and fate of selenium in the hydrologic and biological systems and the effects on biota. Generally, other traceconstituent concentrations in water and biota were not elevated or were not at levels of concern.

Soils in the Uncompahgre Project area that primarily were derived from Mancos Shale contained the highest concentrations of total and water-extractable selenium. Only 5 of 128 alfalfa samples had selenium concentrations that exceeded a recommended dietary limit for livestock. Selenium data for soil and alfalfa indicate that irrigation might be mobilizing and redistributing selenium in the Uncompahgre Project area.

Distribution of dissolved selenium in ground water is affected by the aqueous geochemical environment of the shallow ground-water system. Selenium concentrations were as high as 1,300 micrograms per liter in water from shallow wells. The highest concentrations of dissolved selenium were in water from wells completed in alluvium overlying the Mancos Shale of Cretaceous age; selenium concentrations were lower in water from wells completed in Mancos Shale residuum. Selenium in the study area could be mobilized by oxidation of reduced selenium, desorption from aquifer sediments, ion exchange, and dissolution. Infiltration of irrigation water and, perhaps nitrate, provide oxidizing conditions for mobilization of selenium from alluvium and shale residuum and for transport to streams and irrigation drains that are tributary to the Gunnison, Uncompahgre, and Colorado Rivers.

Selenium concentrations in about 64 percent of water samples collected from the lower Gunnison River and about 50 percent of samples from the Colorado River near the Colorado-Utah State line exceeded the U.S. Environmental Protection Agency criterion of 5 micrograms per liter for protection of aquatic life. Almost all selenium concentrations in samples collected during the nonirrigation season from Mancos Shale areas exceeded the aquatic-life criterion. The maximum selenium concentrations in surface-water samples were 600 micrograms per liter in the Uncompahgre Project area and 380 micrograms per liter in the Grand Valley. 
Irrigation drainage from the Uncompahgre Project and the Grand Valley might account for as much as 75 percent of the selenium load in the Colorado River near the Colorado-Utah State line. The primary source areas of selenium were the eastern side of the Uncompahgre Project and the western one-half of the Grand Valley, where there is extensive irrigation on soils derived from Mancos Shale. The largest mean selenium loads from tributary drainages were 14.0 pounds per day from Loutsenhizer Arroyo in the Uncompahgre Project and 12.8 pounds per day from Reed Wash in the Grand Valley. Positive correlations between selenium loads and dissolved-solids loads could indicate that salinitycontrol projects designed to decrease dissolvedsolids loads also could decrease selenium loads from the irrigated areas. Selenium concentrations in irrigation drainage in the Grand Valley were much higher than concentrations predicted by simple evaporative concentration of irrigation source water. Selenium probably is removed from pond water by chemical and biological processes and incorporated into bottom sediment. The maximum selenium concentration in bottom sediment was 47 micrograms per gram from a pond on the eastern side of the Uncompahgre Project.

Selenium concentrations in some aquatic plants and aquatic invertebrates exceeded a dietary guideline of 3 micrograms per gram dry weight for protection of fish and wildlife resources. More than 75 percent of wholebody fish samples collected from rivers and tributaries throughout the study area had selenium concentrations that exceeded the 1984 National Contaminant Biomonitoring Program 85th-percentile concentration of 0.73 microgram per gram wet weight. Whole-body fish samples from the Gunnison River had significantly higher geometric mean selenium concentrations than fish samples from the Uncompahgre and Colorado Rivers.

Based on a risk assessment using selenium data for five Grand Valley streams, the selenate form of selenium could be a moderate risk to the swim-up life stage (less than 99 days old) of the endangered Colorado squawfish and to three tested life stages of the endangered razorback sucker. Zinc concentrations in Adobe Creek, Leach Creek, and Indian Wash were in the highrisk category for the swim-up life stage of Colorado squawfish.

Selenium concentrations in food items of migratory birds collected at wetlands in the Uncompahgre Project area exceeded the dietary guideline for protection of consumer wildlife. Fathead minnows from ponds had high selenium concentrations, and the maximum concentration was 110 micrograms per gram dry weight. Selenium concentrations in bird eggs and livers generally were in the range of uncertainty regarding biological risk; however, some samples from the Uncompahgre Project area had selenium concentrations in the high-risk category. Of 65 bird eggs incubated, only one had any visual deformity. Five recently hatched birds and two embryos that were found dead at two ponds in the Uncompahgre Project area had selenium concentrations ranging from 19 to 43 micrograms per gram dry weight, but no abnormalities or deformities were observed.

Toxicity tests on irrigation-drainage water from five Grand Valley streams indicated no significant toxicity differences between control and test samples, except for the test on fathead minnows exposed to water from Leach Creek. Bioaccumulation of selenium from water to biota was significant in the study area, and the highest bioaccumulation factor was about 20,900 from water to bird livers. Selenium accumulates in fish and birds in the study area to levels that would limit human consumption if eaten on a daily basis. It is unlikely that fish and birds taken in the study area are consumed by humans on a daily basis.

\section{INTRODUCTION}

High concentrations of selenium have been detected in irrigation drainage in the San Joaquin Valley in California. In 1983, incidences of mortality, abnormalities, and reproductive failure in waterfowl 
were discovered by the U.S. Fish and Wildlife Service (FWS) at the Kesterson National Wildlife Refuge in the western San Joaquin Valley, California, where irrigation-drainage water was impounded. Because of the concern that problems related to selenium or other trace inorganic or organic constituents in irrigation drainage might not be limited to the Kesterson Reservoir area, the U.S. Department of the Interior (DOI) began a program in 1985 to determine whether irrigation-related problems existed at other DOI constructed or managed irrigation projects, national wildlife refuges, or other wetland areas for which the DOI has responsibility. About 600 irrigation projects and major wildlife resource areas have been constructed or are managed in 17 Western States by DOI bureaus. The program evolved into five phases (Deason, 1986): (1) Site identification, (2) reconnaissance investigations, (3) detailed studies, (4) planning, and (5) remediation. Activities in the first three phases are conducted by study teams consisting of scientists from the U.S. Geological Survey (USGS), the FWS, the Bureau of Reclamation (BOR), and the Bureau of Indian Affairs. A USGS scientist heads each study team. Phase 4 and phase 5 of the program are headed by the BOR.

The reconnaissance investigations are designed to determine whether irrigation drainage (1) has caused or has the potential to cause harmful effects on human health or on fish and wildlife or (2) might limit the suitability of water for beneficial uses. The duration of the reconnaissance investigations was about 2 years. Detailed studies were initiated if the reconnaissance investigations indicated that potentially serious water-quality problems were related to irrigation drainage. The purpose of detailed studies is to gather sufficient information to provide the scientific understanding needed for development of reasonable alternatives to mitigate or resolve identified problems. The purpose of planning is to develop coordinated action with appropriate Federal, State, and local agencies and water users for remediation of problem areas. The final phase involves implementation of remedial actions developed during planning.

A reconnaissance investigation of the Gunnison and Uncompahgre River Basins and of Sweitzer Lake (fig. 1) documented elevated concentrations of selenium in some water, bottom-sediment, and biota samples collected in 1987-88 (Butler and others, 1991). The reconnaissance report indicated that irrigation drainage from the Uncompahgre Project, a BOR irrigation project, might be a primary source of selenium, dissolved solids, and other constituents to the Gunnison and Uncompahgre Rivers and to Sweitzer Lake. The extent of the irrigated area served by the Uncompahgre Project is shown in figure 1. The Uncompahgre Project area is defined as the irrigated area served by the Uncompahgre Project plus adjacent areas in the lower Gunnison River Basin, such as the Smith Fork, North Fork, and Tongue Creek Basins (fig. 1). Because of the limited scope of the reconnaissance studies, source areas and distribution of selenium in the Uncompahgre Project area were not determined, nor were effects to biota documented. Also, trace-element data for water and biota were not collected in other irrigated areas in the lower Gunnison River Basin. Because of these factors, a detailed study of the Uncompahgre Project area was initiated in 1991.

The Grand Valley was included with the Uncompahgre Project area in the detailed study. There are similarities of climate, physiography, agricultural crops, and geology between the Grand Valley and the Uncompahgre Project area. Also, the BOR identified irrigation drainage in the Grand Valley (fig. 1) as a large source of dissolved solids (salinity) to the upper Colorado River (Bureau of Reclamation, 1978). A marine shale, the Mancos Shale, was identified as the primary source of the salinity, and selenium problems have been documented in other Western States where marine shales are irrigated (See and others, 1992; Stephens and others, 1992). Historical selenium data for the Colorado and Gunnison Rivers also indicated that the Grand Valley might be a source area of selenium.

\section{Purpose and Scope}

This report describes results of the detailed study of the Uncompahgre Project area and of the Grand Valley during 1991-93. The general objectives of the detailed study are (1) to determine the sources, distribution, movement, and fate of contaminants in the hydrologic and biologic systems; and (2) to measure contaminant concentrations, determine exposure pathways, and document effects on biota. 


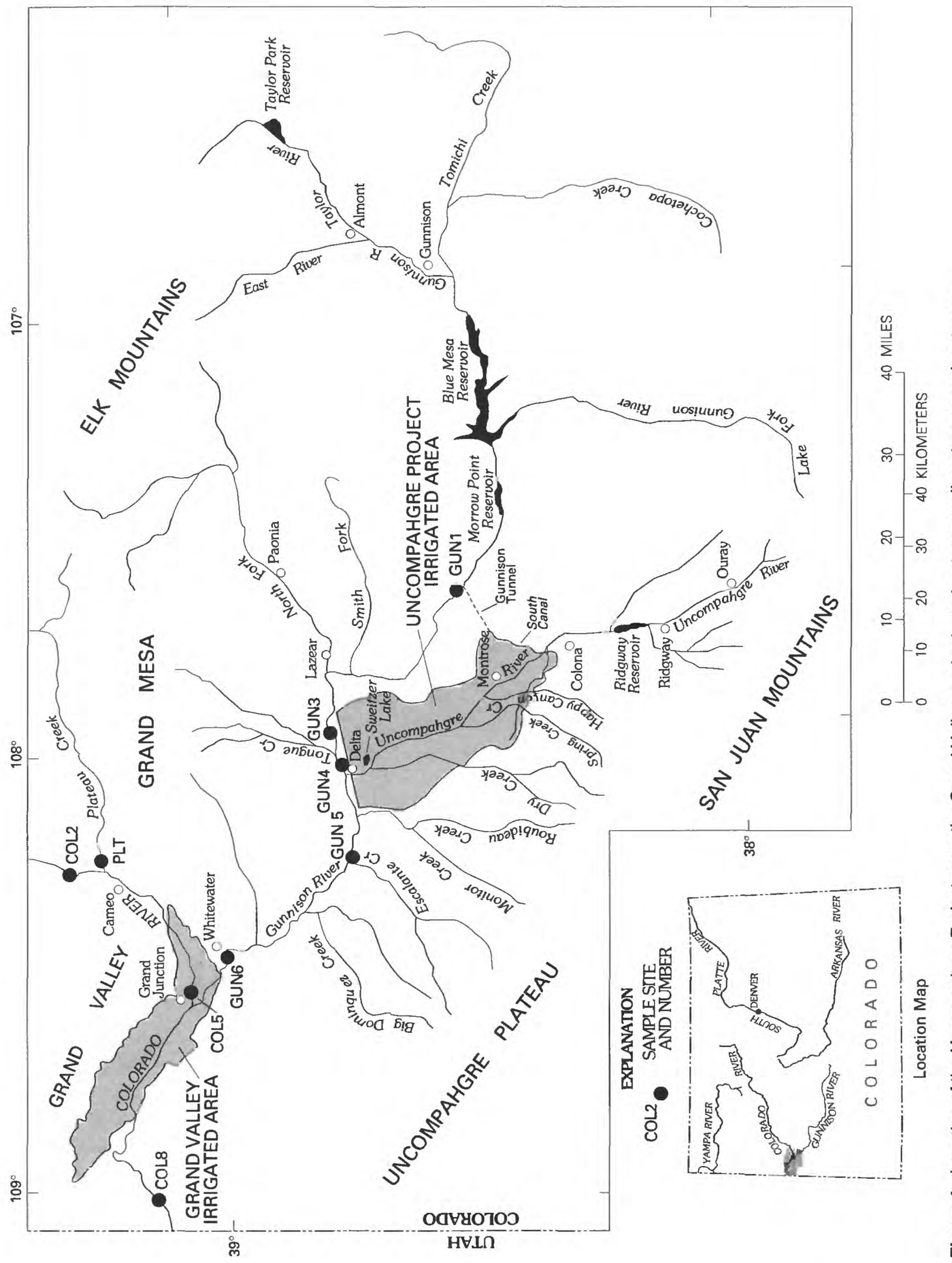


Specific objectives of this report are to:

1. Describe concentrations and distribution of selenium and other trace constituents in soil and in alfalfa in irrigated areas of the Uncompahgre Project.

2. Describe the concentrations and distribution of selenium and other trace constituents in ground water in the Uncompahgre Project area and in the Grand Valley and the hydrochemical processes affecting selenium release and mobilization in ground water in irrigated areas on Mancos Shale terrain.

3. Discuss selenium concentrations and loads in the Gunnison and Colorado Rivers.

4. Describe distribution and variability of selenium concentrations in surface water and in bottom sediment in irrigated areas in the Uncompahgre Project area and in the Grand Valley.

5. Discuss selenium loads in streams, washes, and drains in the Uncompahgre Project area and in the Grand Valley and identify areas that are major sources of selenium to the Gunnison, Uncompahgre, and Colorado Rivers.

6. Describe concentrations and distribution of dissolved solids, major constituents, and selected trace constituents in surface water in the Uncompahgre Project area and in the Grand Valley and the relations of selenium to dissolved solids and selected constituents.

7. Describe concentrations and distribution of selenium and other trace constituents in fish, aquatic plants, and aquatic invertebrates in tributary streams and washes draining the Uncompahgre Project area and the Grand Valley.

8. Describe concentrations and distribution of selenium and other trace constituents in fish from the Gunnison, Uncompahgre, and Colorado Rivers and the potential effects of selenium on threatened and endangered fish.

9. Describe concentrations and distribution of selenium and other trace constituents in waterfowl and their effects on waterfowl reproduction in the Uncompahgre Project area and in the Grand Valley.

10. Discuss food-chain bioaccumulation of selenium.

11. Discuss implications of selenium concentrations to human health.
Soil, alfalfa, ground-water, mineralogic, surface-water, bottom-sediment, and biota samples were collected from March 1991 to August 1992 in the Uncompahgre Project area and in the Grand Valley. Selenium was the trace constituent of primary concern. Some water, bottom-sediment, and aquifersediment samples were analyzed for selenate and selenite selenium. Other trace elements were analyzed in water and biota samples collected in 1991. Also, streams and reservoirs outside the irrigated land served by the Uncompahgre Project (fig. 1) were sampled to determine if selenium and other traceconstituent concentrations were of concern in other irrigated areas in the lower Gunnison River Basin.

Soil and alfalfa samples were collected in irrigated areas of the Uncompahgre Project in June 1991. Soil samples were analyzed for total and extractable selenium, and trace constituents and alfalfa samples were analyzed for total selenium. Groundwater samples were collected in February and March 1992 to define ground-water quality during the nonirrigation season. Some ground-water samples were analyzed for hydrogen, oxygen, and sulfur isotopes. Samples of bedrock core, shale residuum, alluvium, and ground-water filtrate were collected for semiquantitative analyses of clay and bulk mineralogy.

Reconnaissance-level sampling of streams was done in 1991 in the Uncompahgre Project area and in the Grand Valley. Detailed synoptic sampling of streams, washes, and ditches draining irrigated areas in the Uncompahgre Project and in the Grand Valley was done during January through March 1992. Constituents analyzed in synoptic samples were selenium, boron, nitrite plus nitrate, dissolved solids, and major constituents. Selenium data were collected at selected surface-water sites in 1993 and were used for analyses of selenium distribution and loads in the study area. Bottom-sediment samples were collected from selected streams and ponds in 1992.

Biota samples collected in 1991 included aquatic plants and invertebrates, fish, birds, and bird eggs. Sample collection from March to September 1991 was designed to determine if other trace constituents or pesticides were of concern in the Uncompahgre Project and in the Grand Valley. Fish samples were collected from the Gunnison, Uncompahgre, and Colorado Rivers during March and April 1992 for selenium and selected trace-constituent analyses. Wetland sites were monitored for bird usage and nesting from April through July 1992. Birds and 
bird-food items were collected at wetland sites. Bird eggs were collected and incubated. Bioassay samples were collected in March 1992 from five of the major streams in the Grand Valley and analyzed by the

U.S. Environmental Protection Agency.

Water-quality, bottom-sediment, hydrogeologic, mineralogic, and biota data collected for the detailed study are listed in a report by Butler and others (1994). Selenium and other traceconstituent data for the soil and alfalfa samples collected in the Uncompahgre Project area are in a report by Crock and others (1994). Water-extractable data for selenium and other constituents for soil samples are discussed in Stewart and others (1993).

\section{Description of Study Area}

The Uncompahgre Project area and the Grand Valley are located in west-central Colorado (fig. 1). The Uncompahgre Project is located along the Uncompahgre River in the lower Gunnison River Basin. The Uncompahgre Project extends about $34 \mathrm{mi}$ between the towns of Colona and Delta (fig. 2). The irrigated part of the Grand Valley is located along the Colorado River, centered around Grand Junction (fig. 3). The confluence of the Gunnison and Colorado Rivers is at Grand Junction (fig. 3). Other communities in the Grand Valley include Palisade and Clifton, east of Grand Junction, and Fruita and Loma, west of Grand Junction.

\section{Physiography, Soils, Ciimate, and Land Uses}

The Uncompahgre River Valley principally is an agricultural area where irrigation water is supplied by diversion from the Gunnison River through the Gunnison Tunnel (fig. 1) and by water from the Uncompahgre River and its tributaries. About two-thirds of the 86,000 irrigated acres of the Uncompahgre Project is located west of the Uncompahgre River on a series of terraces separated by small valleys that were eroded by tributaries of the Uncompahgre River. The terraces consist of stream deposits and outwash remnants that have relatively low soluble salt content (Bureau of Reclamation. 1984). Irrigated areas east of the Uncompahgre River compose about 34 percent of the project area and consist of soil formed primarily from weathered Mancos Shale. Soils derived from Mancos Shale commonly are referred to as adobe soils and are high in salt content. Alluvial deposits derived primarily from Mancos Shale compose parts of the Cedar Creek and Loutsenhizer Arroyo Basins (fig. 2). Elevation of irrigated areas in the Uncompahgre Project ranges from about 4,900 ft at Delta to about 5,900 ft near Colona.

The approximately 70,000 acres of irrigated land in the Grand Valley are served by Federal and by private irrigation systems. The Federal system serves about 38,000 acres, and the remainder of the irrigated acreage is served by private systems. About 30,000 acres served by the Federal system is located on soils derived from Mancos Shale or from alluvium overlying Mancos Shale between the Colorado River and the Government Highline Canal (fig. 3). The remainder of the Federal system serves irrigated land on Orchard Mesa, a low alluvial terrace located in the southeast part of the Grand Valley (fig. 3). The Grand Valley is relatively flat and gradually slopes upward to the northeast to the Book Cliffs, which are about $1,500 \mathrm{ft}$ above the valley floor. Elevation of irrigated areas in the Grand Valley ranges from about 4,400 to $4,800 \mathrm{ft}$. Numerous small streams and washes dissect the valley and discharge into the Colorado River.

The Uncompahgre Project area and the Grand Valley have an arid to semiarid climate characterized by cool to occasionally cold winters and hot summers. Annual precipitation ranges from about 8 in. at Grand Junction and Delta to 13 in. at Colona. Annual evaporation in both areas is about 50 to 70 in. In most years, snowfall is less than $30 \mathrm{in.}$

The length of the growing season is quite variable in the study area because of local climate variability. The growing season ranges from about 112 to 148 days in the Uncompahgre Project area and from about 150 to 190 days in the Grand Valley. Major crops produced are alfalfa, feed corn, hay, small grains, potatoes, beans, onions, fruit, sweet corn, melons, and soybeans. Cattle are wintered at many farms, and there are numerous small cattlefeeding operations and dairies.

Urban and residential areas in the Uncompahgre Project area are centered around Montrose, Olathe, and Delta. Considerable urban and residential areas are in the Grand Valley in the vicinity of Grand Junction and Clifton. Some agricultural land in both areas has been sold for rural-residential and commercial development. The conversion of agricultural land to nonagricultural uses has been increasing in the study area. 

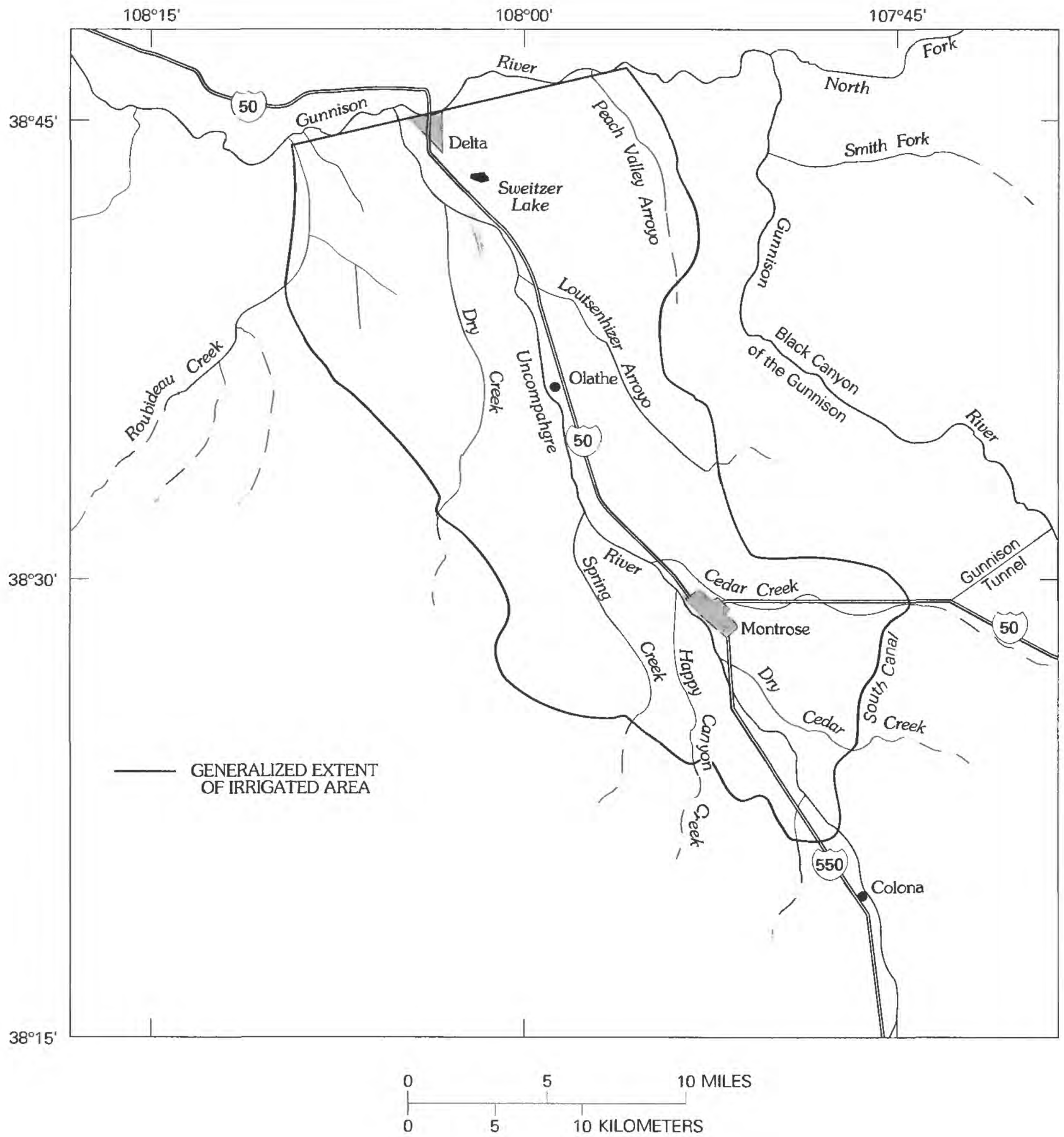

Figure 2. Selected features in the Uncompahgre Project area.

\section{Geologlc Settling}

Rocks exposed in the study area range in age from Precambrian to Upper Cretaceous. The Mancos Shale, the terrace deposits on the western side of the Uncompahgre Project, the valley-fill deposits in the eastern end of the Grand Valley (the cobble aquifer), and the alluvium overlying the Mancos Shale are the primary geologic units affected by irrigation in the study area. Other rocks in the study area primarily are exposed on the outer edges of the irrigated valleys. The following descriptions of the geology of the study area were derived from Meeks (1950), Williams (1964), Lohman (1965), Craig (1971), Schneider (1975), Tweto and others (1976), Schwochow (1978), Cashion (1973), Bureau of Reclamation (1986a), and Steven and Hail (1989). Geologic maps of the irrigated parts of the study area are shown in figures 4 and 5 . 


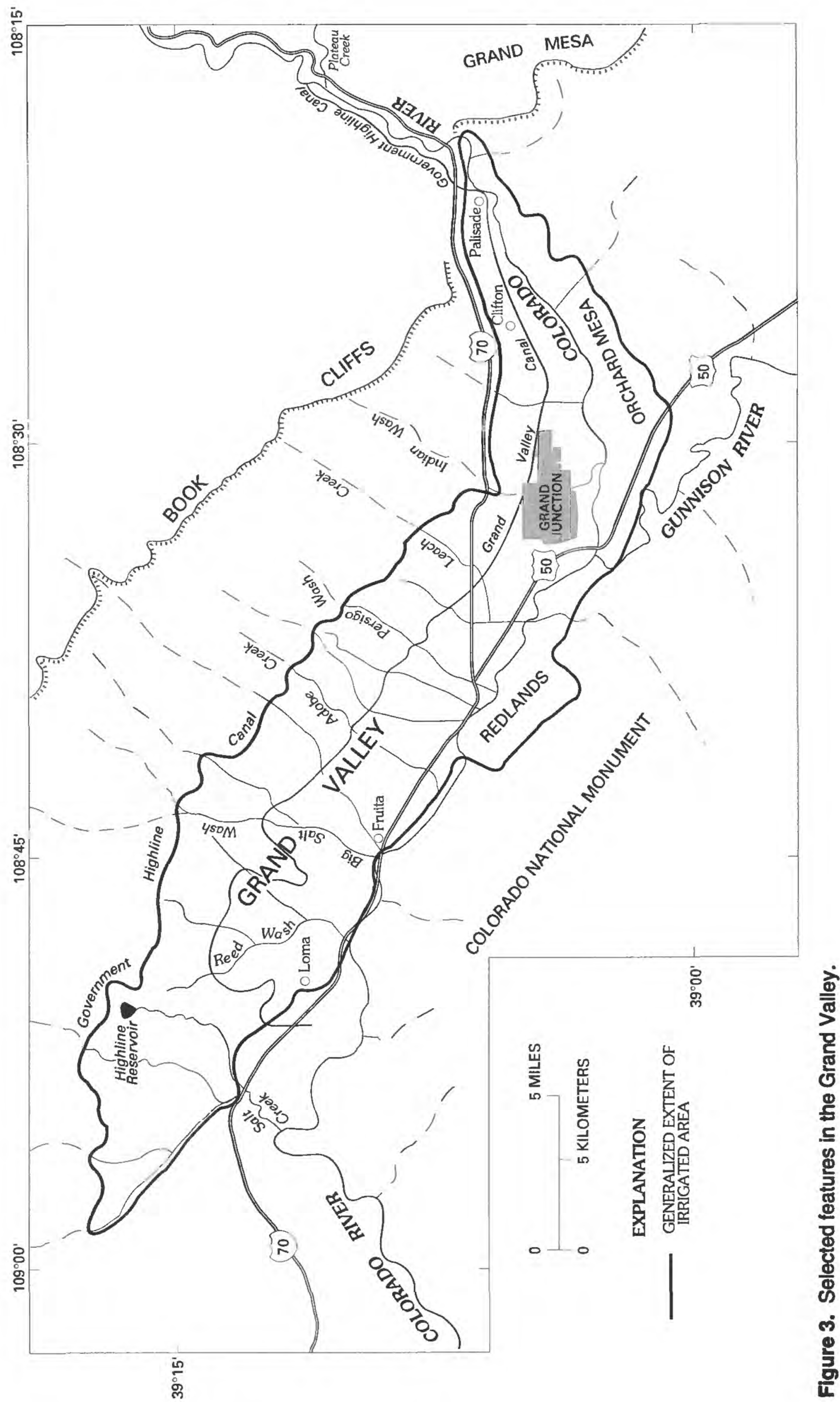



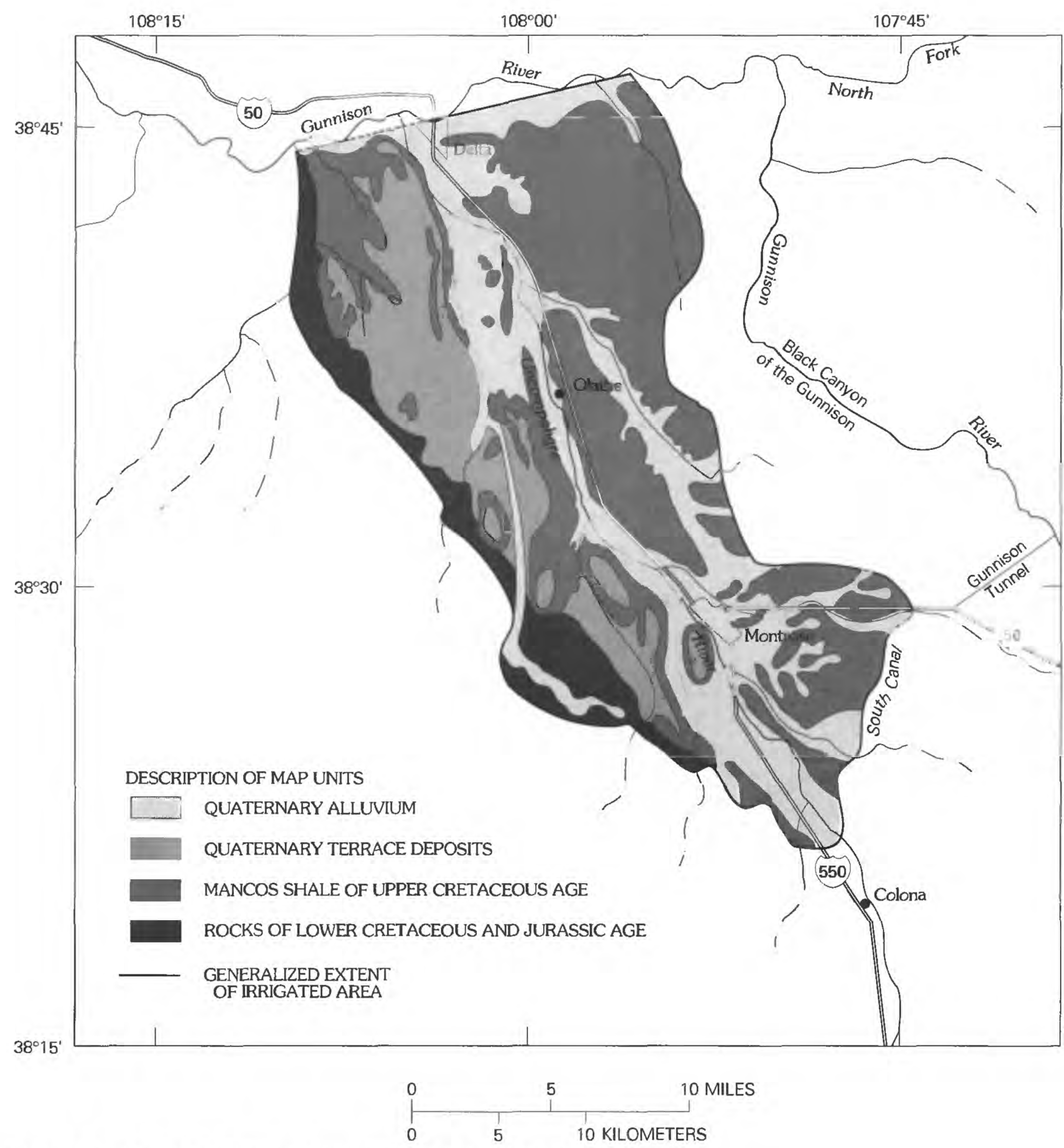

Figure 4. Generalized surficial geology of the Uncompahgre Project

The Mancos Shale of Upper Cretaceous age underlies almost all of the Grand Valley, underlies the eastern one-half and part of the western one-half of the Uncompahgre Project area (figs. 4, 5A), and outcrops in many areas throughout western Colorado and Utah. The formation ranges in thickness from 2,000 to $3,000 \mathrm{ft}$ and consists of massive, fossiliferous marine shale that contains interbedded sandstone, siltstone, and volcanic-ash layers. The Mancos Shale is the lateral equivalent of the Niobrara Formation, Cody Shale, and Pierre Shale in Montana, Nebraska, South Dakota, and Wyoming.

The Mancos Shale is a regressive prodeltaplume complex genetically related to the deltaic systems active along the western interior seaway of Cretaceous age and is divided into the lower shale member, the Ferron Sandstone Member (or the Juana Lopez Member), the Mancos B Member, and the Buck Tongue Member (Cashion, 1973; Gill and Hail, 1975; Cole and Young, 1991). 


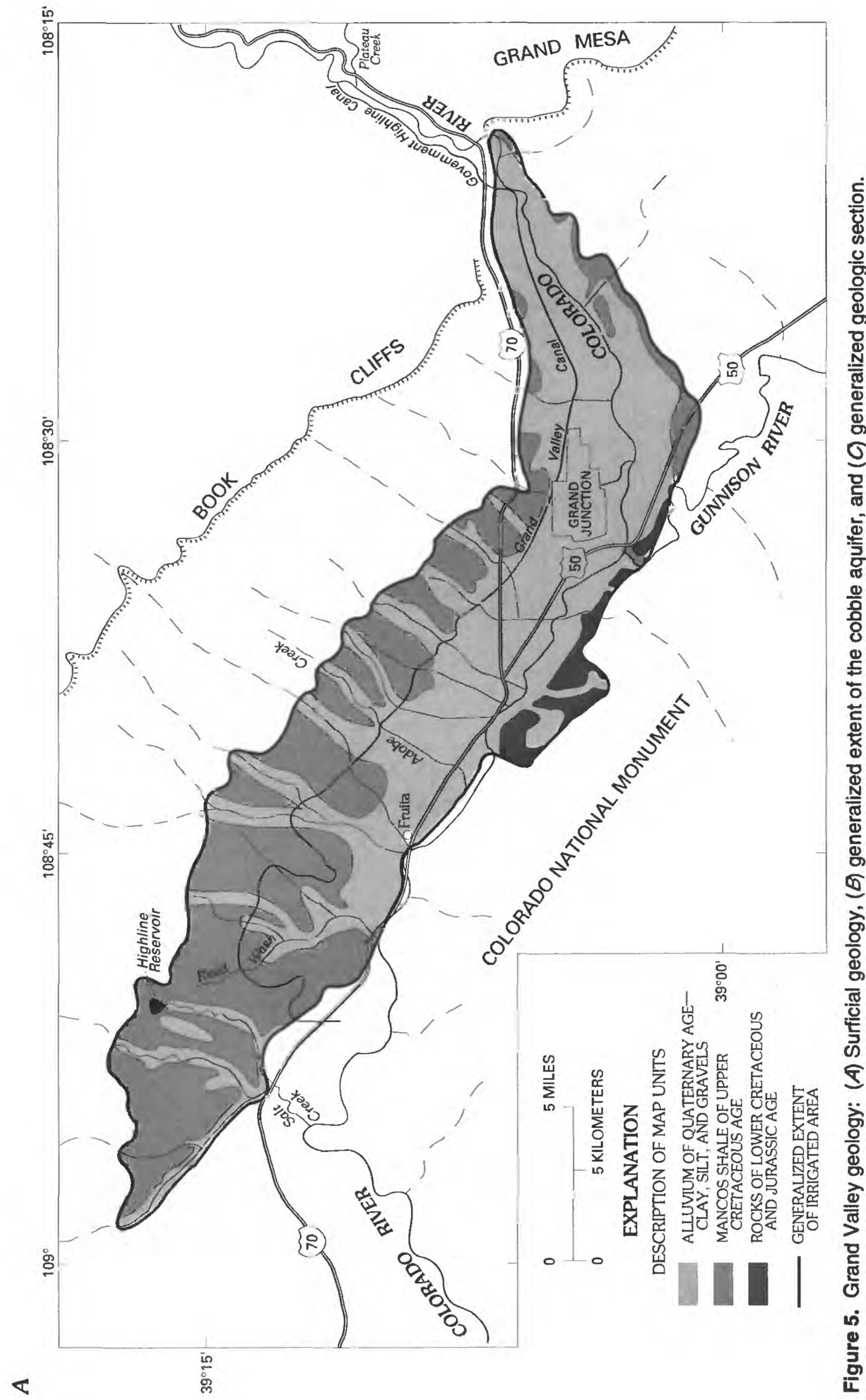

10 Detalled Study of Selenium and Other Constituents in Water, Bottom Sediment, Soll, Alfalfa, and Biola Associated with irrigation Drainage in the Uncompahgre Project Area and in the Grand Valley, West-Central Colorado, 1991-93 
$\boldsymbol{B}$

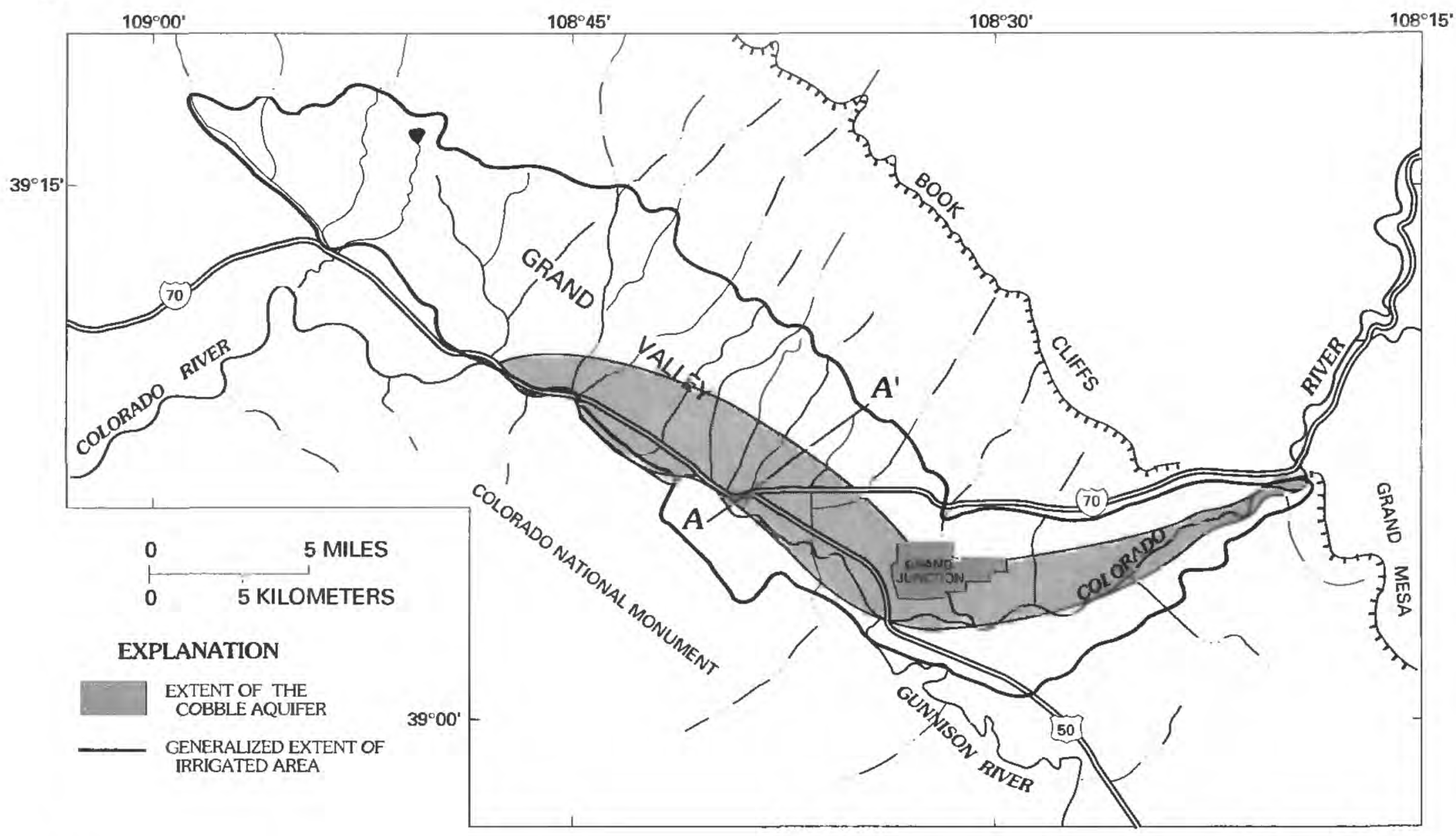

C

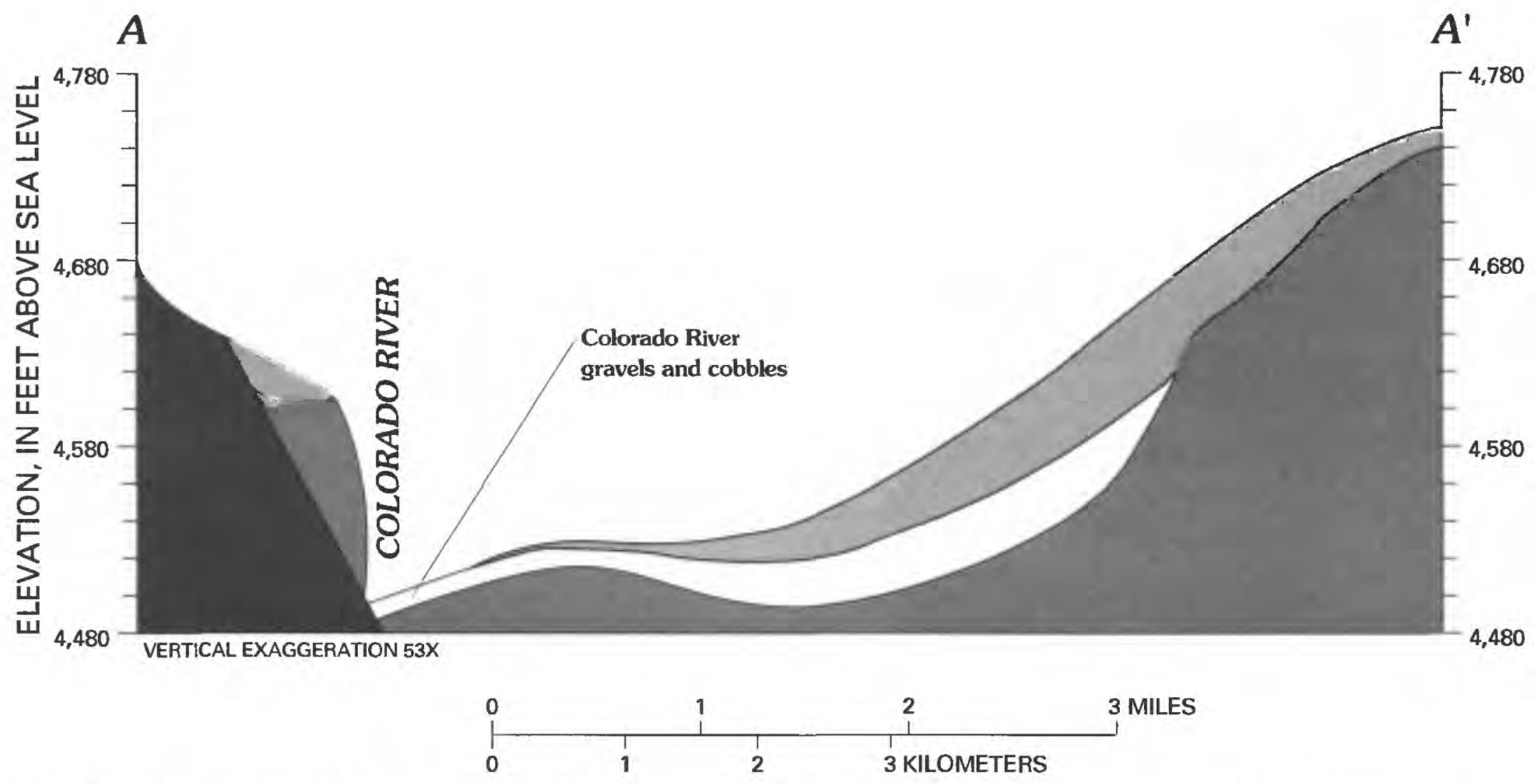

Figure 5. Grand Valley geology: ( $A$ ) Surficial geology, $(B)$ generalized extent of the cobble aquifer, and (C) generalized geologic section-Continued. 
The lower shale member contains massive and laminated silty-mudstone and sandy-siltstone parasequences that contain disseminated pyrite, lenticular kerogen and coal, and pyrite minerals associated with ash beds. Little information is available on the Ferron Sandstone Member. The Mancos B Member (called the Prairie Canyon Member by Cole and Young, 1991) is characterized by lenticular, cyclic, upward parasequences that range in thickness from 6 to $90 \mathrm{ft}$ and consists of five main lithofacies: silty claystone, sandstone-claystone, sandy siltstone, bioturbated muddy sandstone, and sandy dolomite (as beds and concretions). Volcanicash layers occur as interbeds throughout the Mancos Shale and range in thickness from less than 1 in. to $2 \mathrm{ft}$. The ash layers in the study area could have originated from the Sevier Orogeny in central Utah. Volcanic ash could be the source of selenium and other trace constituents in the Mancos Shale.

The Mesaverde Formation of Upper Cretaceous age overlies the Mancos Shale (fig. 5) and forms the caprock for the Book Cliffs that border the northern edge of the Grand Valley. The formation consists of massive sandstone, gray shale, and coal, and ranges in thickness from 60 to $100 \mathrm{ft}$ near the Book Cliffs, but is about 2,300 ft thick in areas north of the Grand Valley. The Mesaverde Formation has been eroded away and is not present in the Uncompahgre Project area.

Terrace deposits on the western side of the Uncompahgre Project area (fig. 4) consist of glacial outwash derived from the San Juan Mountains. These deposits range in thickness from 5 to $60 \mathrm{ft}$ and are poorly sorted materials consisting of fine rock flour, sand, gravel, cobbles, and boulders. The parent material of terrace deposits generally consists of granite, rhyolite, and welded tuff mixed with weathered and transported detritus from the Dakota Sandstone and the Mancos Shale.

Valley-fill deposits in an ancient valley of the Colorado River are in the central and eastern parts of the Grand Valley (fig. $5 B$ ). The deposits were named the "cobble aquifer" (Bureau of Reclamation, 1986a), although the ground-water quality is poor and unacceptable for domestic, agricultural, and industrial uses. The cobble aquifer is late Holocene to Pleistocene in age, ranges in thickness from 10 to $65 \mathrm{ft}$, and consists of well-sorted pebbles, cobbles, and boulders in a sandy matrix. Alluvium and eolian sand may locally cover the gravels (part of the Quaternary clay, silt, and gravels shown in fig. 5A). Mudflows of
Mancos Shale mixed with detritus from the Mesaverde Formation overlies the cobble aquifer in some locations (part of the Quaternary clay, silt, and gravels shown in figure $5 A$ ).

Alluvium overlying the Mancos Shale consists of clay, silt, and gravel deposits of Holocene age. Alluvial deposits commonly are a combination of fluvial sediments and mudflows of Mancos Shale residuum. In the Grand Valley, the alluvium consists of Mancos Shale residuum mixed with detritus weathered from the Mesaverde Formation that forms the caprock for the Book Cliffs (fig. 5). In the Uncompahgre Project area, alluvium overlying the Mancos Shale in the eastern and southeastern parts of the area consists of Mancos Shale residuum mixed with detritus from the Dakota Sandstone, weathered ash-flow tuff, and andesite from the mountains east of the Uncompahgre Project area.

Mineral resources are rich in the areas surrounding the Uncompahgre Project area and the Grand Valley; however, little mineral resource development has occurred in the irrigated areas, except for limited natural gas exploration. Uranium and vanadium have been mined from the Morrison Formation west of the Uncompahgre Plateau; oil shale has been developed in the Green River Formation north and northeast of the Grand Valley; coal has been mined in the Mesaverde Formation and Dakota Sandstone; isolated deposits of copper, gold, molybdenum, beryllium, and titanium have been mined from granitic rocks near Unaweep Canyon south of the Grand Valley; bentonitic clays have been mined from the Morrison Formation; sulfur has been extracted from the Mancos Shale and alunite from the Morrison Formation in the upper Gunnison River Basin; and gypsum, halite, and potash have been mined in the Paradox and Sinbad Valleys along the southwestern edge of the Uncompahgre Plateau. Selenium occurs with many of these mineral deposits; however, the mineral resources development has not affected the irrigated areas on a large scale.

\section{Irrigation Projects}

\section{Uncompahgre Project}

Irrigation began in the 1880's in the Uncompahgre Valley, and by 1890 about 30,000 acres of land were irrigated by private systems that used water from five small diversion 
dams along the Uncompahgre River. In 1901, the State of Colorado began building the 5.8-mi-long Gunnison Tunnel from the Gunnison River to supply more water to the Uncompahgre Valley. Because of insufficient funding, the State could not complete the tunnel, and the BOR completed construction of the Gunnison Tunnel in 1909 (fig. 1) and a diversion dam on the Gunnison River in 1912. The Uncompahgre Project, as it was called, included existing and new canals and laterals. Taylor Park Reservoir (fig. 1) was built in 1937 to supply the project with a dependable water supply. Operation and maintenance of the Uncompahgre Project was transferred to the Uncompahgre Valley Water Users Association in 1932.

The Uncompahgre Project supplies water for irrigation of about 86,000 acres in the lower Gunnison River Basin (figs. 1 and 2). About two-thirds of the irrigated land is west of the Uncompahgre River, where soils are more conducive to agriculture. Historically, diversion of water from the Gunnison River accounted for about two-thirds of the irrigation water for the project, and water from the Uncompahgre River accounted for the remainder of the irrigation water. The Gunnison Tunnel discharges into the South Canal near Highway 50 east of Montrose (fig. 1). Some water from the South Canal is used to irrigate land southeast of Montrose, but most of the water discharges into the Uncompahgre River to augment flows for downstream canal diversions. The irrigation season normally is from early April through October. Historically, water was diverted from the Uncompahgre River into canals during winter (hereinafter referred to as winter water) to provide water for livestock.

A part of the subsurface-irrigation drainage and surface-return flow discharges into the Uncompahgre River upstream from Delta. Much of the water diverted by canals downstream from Montrose consists of return flows (subsurface and surface) from upstream irrigated areas. Between Peach Valley Arroyo and Roubideau Creek (fig. 2), irrigation drainage and return flows from Uncompahgre Project land discharge into the Gunnison River through natural drainage pathways or manmade ditches. There is considerable irrigated land in the lower Gunnison River Basin upstream from Delta, such as in the Smith Fork, North Fork, and Tongue Creek Basins (fig. 1).

\section{Grand Valley}

Settlement began in the Grand Valley in 1881, and the private Grand Valley Canal (fig. 3) was completed prior to 1910. The Grand Valley Canal irrigates approximately the southern one-half of the Grand Valley that is north of the Colorado River between Palisade and Loma (fig. 3). The Government Highline Canal (the Grand Valley Project) was completed in 1917. The Federal system provides water to areas between the Government Highline Canal and the Grand Valley Canal, to Orchard Mesa, and to some areas between Clifton and Palisade. The Grand Valley Water Users Association operates and maintains the Federal system north of the Colorado River, which serves about 30,000 acres. The remainder of the valley north of the Colorado River is served by the private Grand.Valley Irrigation Company. Orchard Mesa is served by the Orchard Mesa Irrigation District, and the Redlands area (fig. 3) is served by the private Redlands Water and Power Company.

The Colorado River is the source of all irrigation water for the Grand Valley, except for the Redlands area, which uses water from the Gunnison River that is diverted about $2 \mathrm{mi}$ upstream from the mouth of the Gunnison River. The Government Highline Canal diverts water from the Colorado River immediately upstream from the confluence with Plateau Creek (fig. 3), and the Grand Valley Canal diverts water near Palisade. Much of the subsurfaceirrigation drainage and surface-return flow discharges into natural streams and washes that dissect the Grand Valley (fig. 3) and discharge into the Colorado River. In addition to natural drains, there is about $600 \mathrm{mi}$ of man-made surface drains, many of which are in the private irrigation system.

\section{Salinity-Control Projects}

In 1974, the Colorado River Basin Salinity Control Act (Public Law 93-320) was passed by the U.S. Congress. That law authorized various investigations and construction of projects with the objective of decreasing the salt (dissolved-solids) loading to the Colorado River. The Uncompahgre Project and the Grand Valley have been included in the salinitycontrol program.

The Lower Gunnison Basin Unit of BOR's Colorado River Water Quality Improvement Program includes the Uncompahgre Project and 
other irrigated areas in the lower Gunnison River Basin. The BOR $(1982,1984)$ estimated that about 360,000 tons/yr of salt from irrigation-induced sources in the Uncompahgre Project is conveyed to the Uncompahgre and Gunnison Rivers, and the salt ultimately is discharged to the Colorado River. The salt loading is attributed to conveyance-system losses, on-farm seepage, and deep percolation of irrigation water into weathered and fractured shale of the Mancos Shale and into alluvium derived from shale. As this irrigation-induced ground water flows through the shale, salt is picked up and eventually is discharged to drains and rivers and, thus, into the Colorado River system.

The Winter Water Replacement Program of the Lower Gunnison Basin Unit (Bureau of Reclamation, 1987 ) provides a replacement winter-water supply for livestock operators who depended on Uncompahgre Project canals and laterals for their livestock watering needs during the winter. Winter canal flows were terminated, and replacement water supplies were provided by expanding the existing rural domesticwater systems. The replacement program was expected to decrease salt loading to the Colorado River by 74,000 tons/yr. As of October 1994, the replacement program was 95 percent complete.

The East Side Lateral Program of the Lower Gunnison Basin Unit is planned to replace about $195 \mathrm{mi}$ of earthen irrigation laterals and about $7 \mathrm{mi}$ of small canals east of the Uncompahgre River with underground pipeline. That program is planned to decrease salt loading from the Uncompahgre Project to the Colorado River by about 65,000 tons/yr. Implementation of the program was scheduled to begin in fiscal year 1995; however, as of early 1996, this project has not been started.

The Grand Valley Unit is a salinity-control project that consists of the Colorado River Valley between Palisade and the Colorado-Utah State line. The Grand Valley Unit contributes an estimated 580,000 tons/yr of salt to the Colorado River through deep percolation of water from canals, laterals, and on-farm irrigation (Bureau of Reclamation, 1983, 1985). Between 1980 and 1982, the BOR lined $7 \mathrm{mi}$ of canal and placed $34 \mathrm{mi}$ of earthen laterals in underground pipeline in the Reed Wash Basin (fig. 3) for a test program known as Stage One (Bureau of Reclamation, 1978). Post-construction monitoring indicated that Stage One improvements decreased the annual salt loading to the Colorado River by 21,900 tons. The Stage Two program of the Grand Valley Unit presently (1996) is under construction and completion is scheduled in 1998 (Bureau of Reclamation, 1985, 1986b). Stage Two is planned to replace about $320 \mathrm{mi}$ of laterals with underground pipeline and to line about $40 \mathrm{mi}$ of canals, decreasing the salt loading to the Colorado River by an estimated 151,000 tons/yr.

The Natural Resources Conservation Service (NRCS), formerly the Soil Conservation Service of the U.S. Department of Agriculture, is conducting the on-farm parts of the salinity-control program in the Lower Gunnison Basin Unit and in the Grand Valley Unit. The total irrigated area in the Lower Gunnison Basin Unit that was studied by NRCS was 171,000 acres, which includes the Uncompahgre Project. The estimated total salt loading from irrigation sources in the Lower Gunnison Basin Unit (the 171,000 irrigated acres) was about 640,000 tons/yr (Bureau of Reclamation, 1984). The NRCS is improving the private on-farm irrigation water delivery and application systems through a volunteer cost-share program. Those improvements include leveling of irrigation land, underground and gated pipelines, sprinkler and drip-application systems, concrete-lined ditches, and associated irrigation watermanagement practices. The NRCS estimates that the total salt decrease attributed to on-farm improvements to be about 166,000 tons/yr in the Lower Gunnison Basin Unit and about 132,000 tons/yr in the Grand Valley Unit (Hedlund, 1994).

\section{Previous Studies}

Much of the water-quality data collected in the study area were for salinity studies. As a result, traceconstituent data often were not collected; however, a few studies provide selenium concentrations in water, soil, plants, and biota in the Uncompahgre Project area and the Grand Valley. Selenium data were collected as early as 1934-36 in the Uncompahgre Project area and in the Grand Valley (Anderson and others, 1961). These data were for the Gunnison and Colorado Rivers in the Grand Junction area, for the Uncompahgre River, for a few drains in irrigated areas of the Uncompahgre Valley and Grand Valley, and for soil and salt-crust samples. Anderson and others (1961) reported a selenium concentration of 
$2,680 \mu \mathrm{g} / \mathrm{L}$ in a new (when the sample was collected in the 1930's) drain near Mack in the Grand Valley. The USGS has collected selenium and other traceconstituent data since 1975 for the Gunnison and Colorado Rivers. These selenium data are summarized later in this report in the "Selenium Concentrations and Loads in the Gunnison and Colorado Rivers" section. The U.S. Department of Energy (1986) collected trace-constituent data, including selenium, from some wells near a uranium mill-tailings pile in Grand Junction.

Because of a suspected problem concerning human consumption of fish that had high levels of selenium, the Colorado Division of Wildlife collected selenium data for fish from Sweitzer Lake near Delta in 1974 and 1977 (Colorado Division of Wildlife, written commun., 1987). A summary of the data is in Butler and others (1991). Because of results of the fish sampling, a sign was posted in 1977 at Sweitzer Lake that warned about high selenium concentrations in fish in the lake.

A reconnaissance investigation of the Gunnison and Uncompahgre Rivers and Sweitzer Lake (Butler and others, 1991) was done in 1988-89 to determine if irrigation drainage from the Uncompahgre Project was affecting water, fish, and wildlife resources. Butler and others (1991) reported high selenium concentrations in some water, bottom-sediment, and biota samples and that the Uncompahgre Project was a significant source of selenium, dissolved solids, and sulfate to the Uncompahgre River. The maximum selenium concentration in water samples was $320 \mu \mathrm{g} / \mathrm{L}$ from the Garnet Canal diversion into Sweitzer Lake. A bottomsediment sample from Sweitzer Lake had $41 \mu \mathrm{g} / \mathrm{g}$ of selenium. Selenium concentrations in wholebody fish samples from Sweitzer Lake ranged from 15.2 to $50.0 \mu \mathrm{g} / \mathrm{g}$ dry weight. There also were large selenium concentrations in some of the bird samples collected from Sweitzer Lake and from the Escalante State Wildlife Area, which is along the Gunnison River downstream from Delta (fig. 1). However, the reconnaissance investigation did not document adverse effects of selenium on fish and birds.

Selenium concentrations in soil, water, vegetables, and field crops in irrigated areas of the Uncompahgre Project and the Grand Valley were reported in Follett and others (1990). Sampling was limited to a few sites in each area. Follett and others
(1990) reported low selenium concentrations in vegetables (broccoli and sweet corn) and in field crops (alfalfa and wheat).

Considerable dissolved-solids and majorconstituent data were collected in the study area for salinity studies and other studies related to agriculture. A study of irrigation-return-flow water quality in the Grand Valley was done by Duke and others (1976). Salinity data collected for a salinitycontrol demonstration project in the Grand Valley were reported by Binder and others (1978). The BOR has done several investigations concerning salinity studies in the Uncompahgre Project (Bureau of Reclamation, 1984, 1987) and in the Grand Valley (Bureau of Reclamation, 1978, 1983, 1985). The report by the BOR (1983) described a detailed water budget for the Grand Valley. The USGS collected dissolved-solids and major-ion data for several streams and washes in the Grand Valley between 1973 and 1983 for the salinity investigations. Whittig and others (1983) did a salinity investigation in the West Salt Creek Basin, located west of irrigated areas in the Grand Valley.

An early survey of soils in the Uncompahgre Valley was done in 1910 by the U.S. Department of Agriculture (Nelson and Kolbe, 1912). A more recent soil survey of the Uncompahgre Project area was done by Cline and others (1967). A study of soil in saline areas of the Grand Valley was done by Fireman and others (1951). Spears and Kleven (1978) did a soil survey of Mesa County, which includes the Grand Valley. Lusby (1978) described results of a longterm study of grazing effects on sediment runoff in a nonirrigated area in the western end of the Grand Valley.

Meeks (1950) investigated geology and ground water in the irrigated areas of the Uncompahgre Valley. Another investigation of ground water in the Uncompahgre Valley was done by Craig (1971). A reconnaissance study of ground-water resources in the lower Gunnison River Basin was described by Brooks and Ackerman (1985). Lohman (1965) described the geology and hydrology of artesian aquifers in the Grand Valley. Uranium and selenium-indicator plants that were used for uranium prospecting in the Colorado Plateau are described by Cannon (1954).

The BOR did several water-resource and hydrogeologic investigations of the Uncompahgre Project and the Grand Valley as part of the salinitycontrol projects in each area. A report by the BOR 
(1977) contains ground-water reconnaissance and well-inventory information for the Uncompahgre Project (Lower Gunnison Basin Unit). The report also has some water-quality data, including data for arsenic and boron concentrations in ground water. Information about land and water resources, the irrigation system, water quality, and hydrogeology for the Uncompahgre Project is in two BOR reports (1982, 1984). Hydrogeologic investigations related to irrigation in the Grand Valley were reported in three BOR reports $(1978,1986 a, b)$. The report from 1978 describes a detailed hydrogeologic investigation of the Reed Wash Basin for the Stage One salinity project. Geologic logs and salt-loading information for the cobble aquifer in the Grand Valley are in a BOR report (1986a).

Studies have been done since the early 1980's concerning threatened and endangered fish species in the Upper Colorado River Basin, and part of that work was done in the Grand Valley area. Most of the studies in the Grand Valley area concerned the Colorado River squawfish and the razorback sucker. Behnke and Benson (1983) and Archer and others (1985) described population, habitat, and reservoir effects on endangered fish in the Upper Colorado River Basin. A study of bonytail chub was described in Kaeding and others (1986), and a study of Colorado squawfish and razorback suckers in a reach of the Colorado River in the Grand Valley was described by Osmundson and Kaeding (1989). Concentrations of trace constituents in Colorado squawfish were described by Krueger (1988). Concentrations of organochlorine pesticides and trace constituents in endangered fish were described in Kurey (1985a, b).

\section{Acknowledgments}

The authors thank the numerous property owners for allowing access to their property for collection of samples. We also thank Jack Cunningham and Kenneth Weston (BOR) for compilation of historical ground-water and aquifer-test data, Roger Fujii (USGS) for selenium-speciation analysis and for his insights concerning selenium geochemistry, David Wolny for his interpretation and valuable information on the local geology, and Jeffery Foster (USGS) for assistance with collection of surfacewater and ground-water data. The authors also thank Larry Fukui of RUST Geotech, Inc., in Grand Junction, Colo., for mineralogic analysis, and Dorothy Hahn and Carol Burns for assistance with biota sampling and data compilation. Bioassay tests on water and bottom sediment were done with the help of the following employees of the U.S. Environmental Protection Agency: Loys Parrish and Bill Schroeder in Denver, Colo., and Mark Smith in Cincinnati, Ohio.

\section{SOILS AND ALFALFA INVESTIGATIONS}

An unbalanced, four-level, stratified random sampling design was used to define sources, distribution, and variability of selenium and other traceconstituent concentrations in the soils and associated alfalfa among and within geologic units in the Uncompahgre Project area. As part of the soilsampling scheme, geologic units were mapped and described based on earlier geologic maps and soilsurvey maps of the project area (Marshall, 1959; Williams, 1964; Cline and others, 1967; Tweto and others, 1976; Steven and Hail, 1989). Soils derived from five geologic units were sampled: Upper Cretaceous Dakota Sandstone (Kd); Upper Cretaceous Mancos Shale (Km); Quaternary deposits in ancient terraces and alluvial fans $(\mathrm{Qt})$; Quaternary (Holocene) alluvium overlying Mancos Shale (Qm); and Quaternary (recent) flood-plain alluvium deposited by the Uncompahgre River and other streams (Qr). In the Uncompahgre Project area, most of the soils of unit Qm were derived from Mancos Shale. One site was sampled on Quaternary alluvium derived from Dakota Sandstone (Qd).

Fifteen townships were included in the study area, and the distribution of soil-sampling sites is shown in figure 6. All soil samples were collected in irrigated areas. Random sections were selected in each township until all geologic units in a township had been selected, in triplicate, for soil and alfalfa sampling (fig. 6). The sample distributions by geologic unit from the randomly selected sections are listed in table 1. Township 4 had four sites for the geologic unit $\mathrm{Km}$; geologic unit Qd was sampled only in township 13 (table 1). If a preselected site was unacceptable in the field because of irrigation or absence of alfalfa, a new site was selected in an adjacent section as close as possible to the original site. To assess variability within a section, two samples about $100 \mathrm{~m}$ apart were collected in 14 randomly selected sections. 


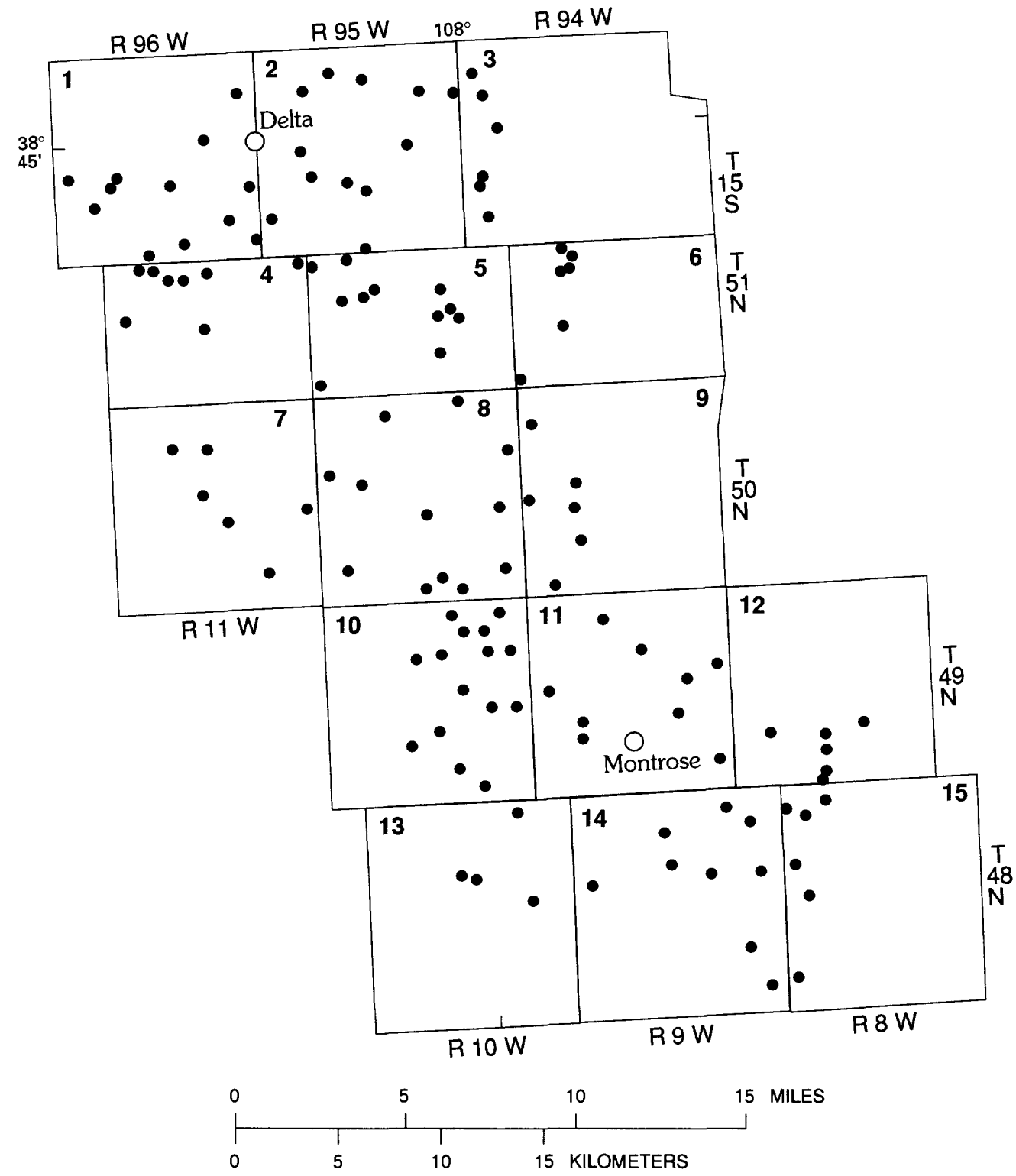

Figure 6. Distribution of soil-sampling sites within townships in irrigated areas of the Uncompahgre Project.

Soil cores of $1 \mathrm{~m}$ were removed using a 9-cm bucket auger, and the entire core was homogenized by mixing in a plastic container. A $1-\mathrm{kg}$ portion of the 1-m core mixture was placed in a paper bag for transport to the laboratory. The top $20 \mathrm{~cm}$ of several alfalfa plants (Medicago sativa L.) at 10-percent bloom stage were sampled within a few meters of the auger bore, composited, placed in paper bags, and air dried. At several sites, alfalfa could not be obtained, and only the soil cores were taken.

\section{Sample Preparation and Analytical Methods}

Soil samples were air dried in the laboratory at ambient room temperature (about $20^{\circ} \mathrm{C}$ ), disaggregated using a mechanical mortar and pestle, and sieved to pass a 2-mm screen (10 mesh). A split of this material was ground to less than 100 mesh using a ceramic-plate grinder. The split was used for total analysis; the unground, 2-mm fraction was used for extractions. Field-dried alfalfa samples were washed 
Table 1. Distribution of soil-sampling sites by geologic units in townships of the Uncompahgre Project area

[Numbers under geologic unit indicate the number of sites in each unit within each township; geologic units are defined as follows: Kd, Upper Cretaceous Dakota Sandstone; Km, Upper Cretaceous Mancos Shale; Qt, Quaternary terrace and alluvial-fan deposits; Qm, Quaternary (Holocene) alluvium overlying Mancos Shale; Qr, Quaternary (recent) flood-plain alluvium deposited by the Uncompahgre River and other streams; Qd, Quaternary alluvium derived from Dakota Sandstone; --, no samples]

\begin{tabular}{|c|c|c|c|c|c|c|c|c|}
\hline \multirow{2}{*}{$\begin{array}{l}\text { Township } \\
\text { number } \\
\text { (fig. 6) }\end{array}$} & \multirow{2}{*}{ Township } & \multirow{2}{*}{$\begin{array}{c}\text { Range } \\
\text { (all west) }\end{array}$} & \multicolumn{6}{|c|}{ Geoiogic unit } \\
\hline & & & Kd & Km & $\mathbf{Q t}$ & Om & Qr & Qd \\
\hline 1 & 15 south & 96 & -- & 3 & 3 & 3 & 3 & -- \\
\hline 2 & 15 south & 95 & -- & 3 & 3 & 3 & 3 & .- \\
\hline 3 & 15 south & 94 & -- & 3 & -- & 3 & -- & -- \\
\hline 4 & 51 north & 11 & -- & $1_{4}$ & 3 & - & -- & -- \\
\hline 5 & 51 north & 10 & -- & 3 & 3 & 3 & 3 & -- \\
\hline 6 & 51 north & 09 & -- & 3 & 3 & -- & -- & -- \\
\hline 7 & 50 north & 11 & 3 & -- & 3 & -- & -- & -- \\
\hline 8 & 50 north & 10 & - & 3 & 3 & 3 & 3 & -- \\
\hline 9 & 50 north & 09 & - & 3 & -- & 3 & -- & -- \\
\hline 10 & 49 north & 10 & 3 & 3 & 3 & 3 & 3 & -- \\
\hline 11 & 49 north & 09 & - & 3 & -- & 3 & 3 & -- \\
\hline 12 & 49 north & 08 & -- & 3 & -- & 3 & -- & -- \\
\hline 13 & 48 north & 10 & 3 & -- & -- & -- & -- & $2_{1}$ \\
\hline 14 & 48 north & 09 & -- & 3 & -- & 3 & 3 & -- \\
\hline 15 & 48 north & 08 & -- & 3 & -- & 3 & -- & -- \\
\hline
\end{tabular}

using tap water, rinsed several times in demineralized water, redried at ambient room temperature, and ground to pass a 2-mm screen in a Wiley mill. Each ground sample was mixed and split, and a part was ashed at $450^{\circ} \mathrm{C}$ in a muffle furnace for 24 hours.

Soils and plant ash were decomposed using a low-temperature mixed acid digestion (Crock and others, 1983). Solutions were analyzed simultaneously for 40 constituents using inductively coupled plasma atomic-emission spectroscopy (ICP-AES) (Crock and others, 1983). Soils and dried plant material for arsenic and selenium determinations were decomposed by mixed acids and hydrogen peroxide (Crock and others, 1994). Determinations were made by hydride-generation atomic absorption spectroscopy (HGAAS) (Crock and Lichte, 1982; Sanzolone and Chao, 1987).

Extractions on soils were done using deionized water (one part soil to five parts water, by weight) by agitation for 16 hours on a horizontal reciprocating shaker (Stewart and others, 1990). Solutions were clarified by centrifugation and filtration $(0.45-\mu \mathrm{m}$ filter). Conductivity, $\mathrm{pH}$, and anion concentrations were determined in solution by conductivity meter, standard combination $\mathrm{pH}$ electrode, and ion chromatograph (Wilson and others, 1987; Stewart and others, 1990). A part of each solution was predigested to oxidize organic matter, according to a modification developed by Presser and Barnes (1985), prior to arsenic and selenium determination by HGAAS.

\section{Selenium Concentrations in Soils and Alfalfa}

The geometric means and ranges for total selenium in all soil samples from the Uncompahgre Project area and in soil samples from each geologic unit (Crock and others, 1994) are listed in table 2. Total-selenium concentrations in the 142 soil samples ranged from 0.1 to $8.6 \mu \mathrm{g} / \mathrm{g}$ (table 2). The geometric mean selenium concentration for all soil samples was $1.4 \mu \mathrm{g} / \mathrm{g}$, compared to a geometric mean of $0.23 \mu \mathrm{g} / \mathrm{g}$ for Western soils (Shacklette and Boerngen, 1984). 
Residual soils derived from Mancos Shale $(\mathrm{Km})$ and alluvium overlying Mancos Shale (Qm) contained the highest geometric mean selenium concentrations of 2.2 and $2.9 \mu \mathrm{g} / \mathrm{g}$ (table 2). These values are 10 to 13 times the geometric mean for Western soils. The geometric mean total-selenium concentrations in soils derived from the Quaternary terrace deposits $(\mathrm{Qt})$, recent flood-plain alluvium $(\mathrm{Qr})$, and Dakota Sandstone $(\mathrm{Kd})$ were lower than the geometric mean concentrations in soils derived from Mancos Shale $(\mathrm{Km})$, but exceeded the geometric mean for Western soils.

The geometric mean concentrations of waterextractable selenium for the soil samples, grouped by geologic unit, are listed in table 2. Concentrations ranged from 0.005 to $1.8 \mu \mathrm{g} / \mathrm{g}$ dry weight. As with the results of total-selenium analysis, the geometric mean concentration of water-extractable selenium was higher in alluvium overlying Mancos Shale (Qm) than in the residual soils derived from Mancos Shale (Km). The percent of total selenium that was water extractable was uniformly low for all geologic units and ranged from 1.5 to 2.7 percent.

Total-selenium concentrations in 128 alfalfa samples from the Uncompahgre Project area ranged from less than 0.03 to $9.5 \mu \mathrm{g} / \mathrm{g}$ dry weight (table 2).
Data for individual samples are listed in Crock and others (1994). The geometric mean selenium concentration of $0.33 \mu \mathrm{g} / \mathrm{g}$ (table 2) for all alfalfa samples exceeded the recommended minimum for cattle feed of $0.1 \mu \mathrm{g} / \mathrm{g}$ (Fisher and others, 1987). Only five alfalfa samples exceeded the recommended dietary tolerance limit of $4 \mu \mathrm{g} / \mathrm{g}$ (Byers, 1935). The alfalfa data from the Uncompahgre Project area indicates lower selenium concentrations compared to the Kendrick Reclamation Project area in Wyoming, where 15 percent of alfalfa samples from irrigated fields exceeded the tolerance limit (See and others, 1992). As with total and water-extractable selenium in soil, the highest geometric mean selenium concentrations in alfalfa were in plants growing on alluvium overlying Mancos Shale (Qm).

Selenium concentrations in alfalfa do not show the same trend as selenium concentrations in soil when the geometric means for the geologic units are compared. Residual soils derived from Mancos Shale (Km) and Quaternary terrace deposits $(\mathrm{Qt})$ contained higher total-selenium concentrations in soil than did recent flood-plain alluvium (Qr), but selenium concentrations in alfalfa from units $\mathrm{Km}$ and Qt were significantly lower (significance level 0.05 ) than the concentrations in alfalfa from unit $Q$ r.

Table 2. Geometric mean and observed range of total- and water-extractable selenium concentrations in soil and totalselenium concentrations in alfalfa for all samples from the Uncompahgre Project area, by geologic unit

[Selenium concentrations in soil and alfalfa, in micrograms per gram; geologic units are defined as follows: Kd, Upper Cretaceous Dakota Sandstone; Km, Upper Cretaceous Mancos Shale; Qt, Quaternary terrace and alluvial-fan deposits; Qm, Quaternary (Holocene) alluvium overlying Mancos Shale; Qr, Quaternary (recent) flood-plain alluvium deposited by the Uncompahgre River and other streams; <, less than; analytical duplicates not included; data for all samples includes one sample for geologic unit Qd, Quaternary alluvium overlying Dakota Sandstone]

\begin{tabular}{|c|c|c|c|c|c|c|}
\hline Statistic & All samples & Kd & $\mathbf{K m}$ & Qt & $\mathbf{Q m}$ & $\mathbf{Q r}$ \\
\hline \multicolumn{7}{|c|}{ SOIL, TOTAL SELENIUM ${ }^{1}$} \\
\hline Detection ratio & 142:142 & $11: 11$ & 43:43 & $28: 28$ & $36: 36$ & $23: 23$ \\
\hline Geometric mean & 1.4 & .5 & 2.2 & 1.0 & 2.9 & .6 \\
\hline Observed range & $.1-8.6$ & $.3-.6$ & $.3-7.5$ & $.3-3.4$ & $.9-8.6$ & $.1-2.9$ \\
\hline \multicolumn{7}{|c|}{ SOIL, WATER-EXTRACTABLE SELENIUM ${ }^{2}$} \\
\hline Detection ratio & $128: 128$ & 9:9 & $40: 40$ & $24: 24$ & $33: 33$ & $21: 21$ \\
\hline Observed range & $.005-1.8$ & $.005-.019$ & $.005-1.8$ & $.005-.062$ & $.008-.86$ & $.005-1.0$ \\
\hline \multicolumn{7}{|c|}{ ALFALFA, TOTAL SELENIUM ${ }^{1}$} \\
\hline Detection ratio & 118:128 & $10: 11$ & $31: 35$ & $25: 26$ & $30: 34$ & $21: 22$ \\
\hline Geometric mean & .33 & .12 & .28 & .25 & .56 & .48 \\
\hline Observed range & $<.03-9.5$ & $<.03-.69$ & $<.03-1.6$ & $<.03-1.8$ & $<.03-6.3$ & $<.03-9.5$ \\
\hline
\end{tabular}

${ }^{1}$ Data from Crock and others (1994). Site duplicates were considered independent samples.

${ }^{2}$ Data from Stewart and others (1993). Site duplicates were averaged to obtain one value for each site. 
Selenium in alfalfa from unit Qr was not significantly different from selenium concentrations in alfalfa from alluvium overlying Mancos Shale (Qm), although the flood-plain alluvial soils contained only about 21 percent of total selenium and about 38 percent of the water-extractable selenium as did the soils on alluvium overlying Mancos Shale. In addition, the correlation of total selenium in alfalfa with water-extractable selenium in soils on unit $\mathrm{Qr}$ is 0.77 , which is much higher than the same correlation for all samples of 0.47 (Stewart and others, 1993).

Results from analysis of variance (ANOVA) indicate that selenium distribution in the Uncompahgre Project is not uniform among geologic units or within geologic units. The percent of the variance for total and water-extractable selenium in soil and total selenium in alfalfa that are accounted for by each of the four levels in the ANOVA sampling design (Stewart and others, 1993; Crock and others, 1994) are shown in figure 7. The ANOVA results in figure 7 show the variance among geologic units and the variance within geologic unit at the township, section, and within section scale. Fifty-seven percent of the variance in total selenium in soil was accounted for by geologic units. By contrast, only 30 percent of the total variance in water-extractable selenium in soil is accounted for by geologic units; differences among sections in the same geologic unit accounted for more of the total variance in water-extractable selenium than did differences among geologic units.

Ranges of selenium concentration were much greater in alfalfa from the alluvial units Qm (soils overlying Mancos Shale) and Qr (soils on recent flood-plain alluvium) than the ranges for the other geologic units-Kd (soils derived from Dakota Sandstone), $\mathrm{Km}$ (soils derived from Mancos Shale,

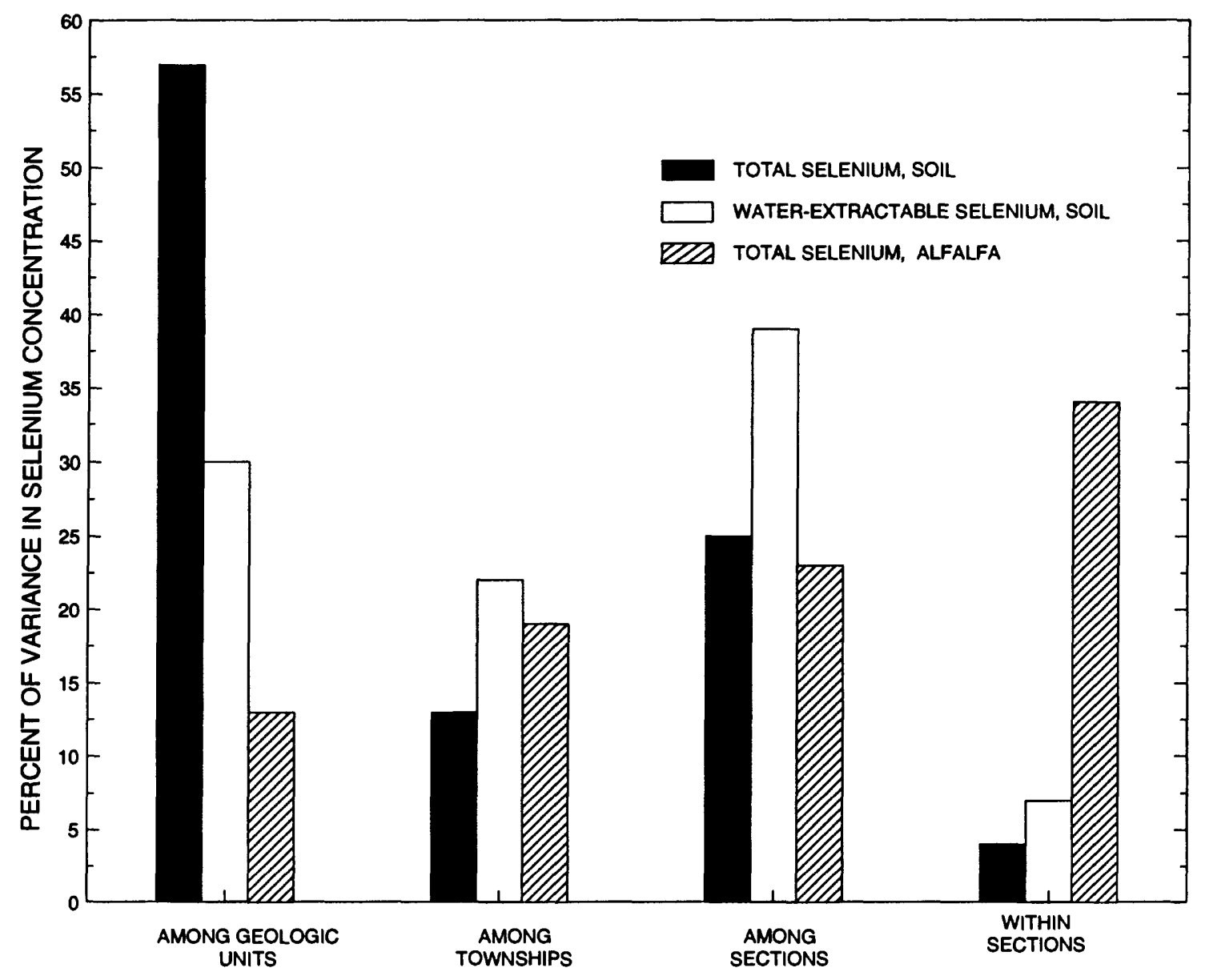

Figure 7. Percent of variance in selenium concentrations in soils and alfalfa for different levels in the sampling design. 
and Qt (soils derived from terrace and alluvial-fan deposits) (table 2). Only 13 percent of the total variation in selenium concentration in alfalfa was attributed to differences among geologic units. About one-third of the total variation resulted from concentration differences within sections, indicating high variability between samples collected in close proximity within the same geologic unit. Similar large variations in selenium concentrations in alfalfa collected in close proximity on the same parent geologic unit were reported for alfalfa in the Kendrick Reclamation Project area in Wyoming (See and others, 1992) and in native vegetation from seleniferous soils in South Dakota (Moxon and others, 1938; Olson and others, 1942).

The results indicate that selenium is mobilized from Mancos Shale and redistributed downslope in the Uncompahgre Project area by irrigation. The ANOVA results and the high correlations of selenium in alfalfa with water-extractable soil selenium, especially in alluvial soils, indicate that the forms of selenium have changed from immobile selenides incorporated in sulfide minerals and selenites sorbed to other iron minerals in the residual shale (Lakin, 1961; Elrashidi and others, 1989) to a higher proportion of the more mobile selenate in the alluvium (Geering and others, 1968; Balistrieri and Chao, 1987). This change in chemical species might occur because of increased exposure to ground water and of changing redox conditions in geographically lower elevations and could be expected to occur under the alkaline soil conditions that are present in the project area. Displacement of selenium downslope from a source area and an increase in content of dissolved species in contact with ground water was reported for the San Joaquin Valley in California (Tidball and others, 1989) and for the Kendrick Reclamation Project area in Wyoming (See and others, 1992). Because the Uncompahgre Project area generally is well drained, selenium does not accumulate to the levels that were reported in soils and alfalfa from the Kendrick Reclamation Project area (See and others, 1992), where irrigation drainage was evaporated in a closed basin.

Other trace constituents of environmental interest that had higher concentrations in soils of the Uncompahgre Project area than in soils in the Western United States were arsenic, molybdenum, uranium, and zinc. Concentrations of these trace constituents were highest in soils from alluvium overlying Mancos Shale (unit Qm), and the geometric means for unit $\mathrm{Qm}$ are listed in table 3. Alfalfa from three of the five geologic units had mean copper to molybdenum ratios of less than $2: 1$. A minimum ratio of $2: 1$ in livestock feed is considered necessary to prevent symptoms of molybdenuminduced copper deficiency in cattle (Miltmore and Mason, 1971; Erdman and others, 1978).

Table 3. Geometric mean concentrations of arsenic, molybdenum, uranium, and zinc in soils from alluvium overlying Mancos Shale in the Uncompahgre Project area and in soils from the Western United States

[Concentrations, in micrograms per gram; data for Western United States soils from Shacklette and Boerngen (1984)]

\begin{tabular}{lcccc}
\hline \multicolumn{1}{c}{ Area } & Arsenic & Molybdenum & Uranlum & Zinc \\
\hline $\begin{array}{l}\text { Uncompahgre Project- } \\
\text { Alluvium from }\end{array}$ & 9 & 5 & 5 & 110 \\
$\begin{array}{l}\text { Mancos Shale } \\
\text { (unit Qm) }\end{array}$ & & & & \\
Western United States & 6 & .9 & 3 & 55 \\
\hline
\end{tabular}

\section{GROUND-WATER INVESTIGATIONS}

The objectives of the ground-water investigations were to describe concentrations and distribution of selenium and other trace constituents in ground water in the Uncompahgre Project area and in the Grand Valley and to describe the hydrochemical processes affecting selenium release and mobilization in ground water in irrigated areas on Mancos Shale terrain. The approach was collection of geologic and ground-water-quality data from type areas that were representative of the hydrogeology of the whole area. Selection of type areas was based on the availability of historical ground-water data, existing wells, and geologic information. The type areas include:

1. Sweitzer Lake area in the eastern part of the Uncompahgre Project area-representing terrane on Mancos Shale residuum (fig. 8);

2. Dry Creek Basin in the western part of the Uncompahgre Project area-representing terrane on Quaternary terrace deposits (fig. 8); and,

3. Reed Wash Basin in the Grand Valleyrepresenting terrane on Mancos Shale residuum and alluvium overlying Mancos Shale (fig. 9).

Hydrogeologic characteristics of the type areas are described in the "Ground-Water Hydrology" section. 

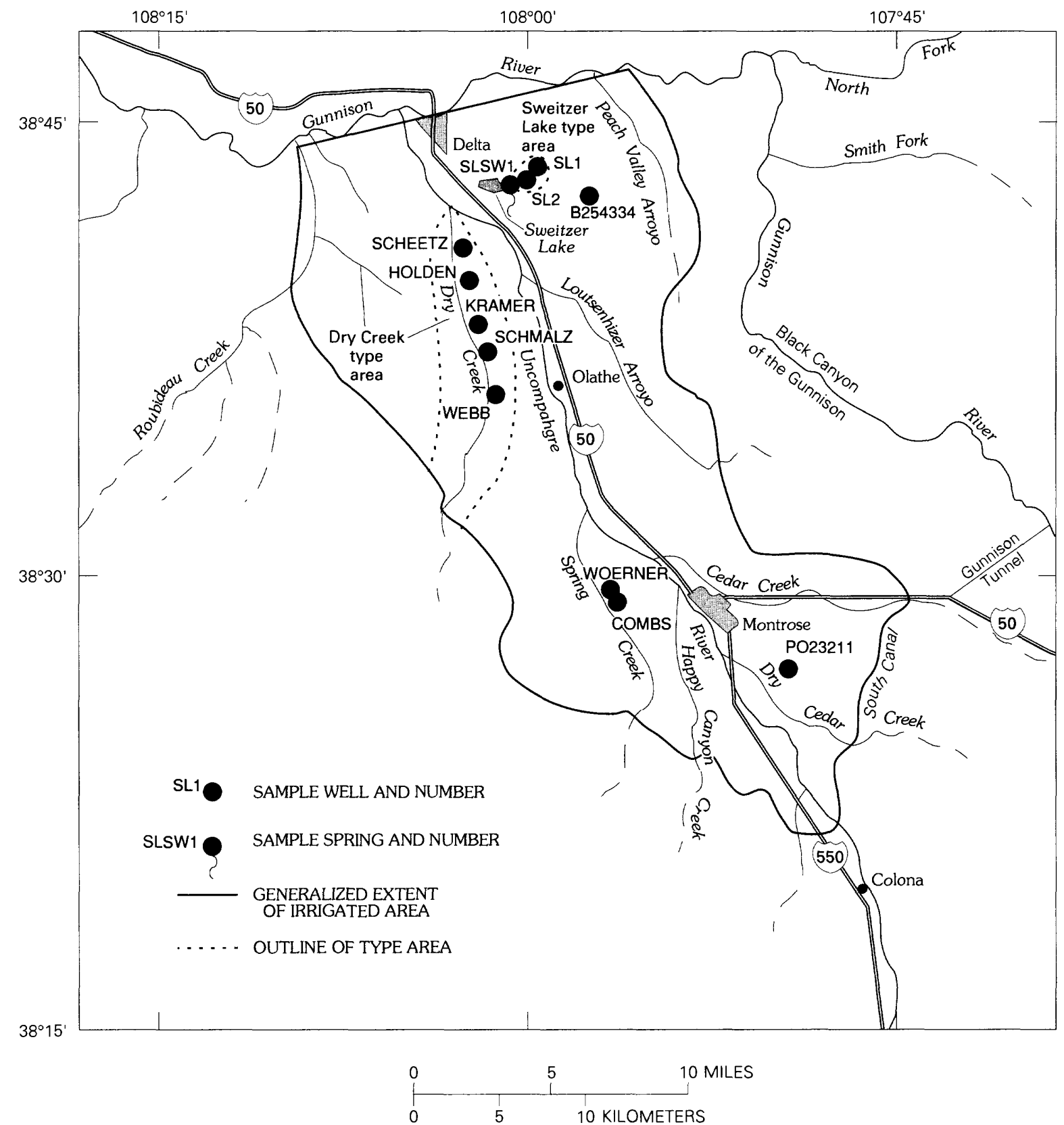

Figure 8. Locations of type areas and locations of wells and springs in the Uncompahgre Project area where samples were collected for chemical analysis.

In the type areas, existing wells were inventoried and historical ground-water data were compiled, wells were installed where needed to supplement the existing wells, sediment-core samples were collected from boreholes, geologic information was compiled, and a data logger was installed in one well. In addition to the type-area investigations, wells were inventoried and ground-water samples were collected over a wide area to describe the areal distribution of selenium and other trace constituents. Deep wells (privately owned) were inventoried and sampled to describe the boundary conditions for possible traceconstituent migration into the study area from deep aquifers. Where available, wells were inventoried and sampled outside the irrigated areas to describe natural or nonirrigated conditions. Samples of Mancos Shale bedrock were collected from cores archived at the USGS Core Research Center in Denver, Colo. Historical ground-water data, aquifer-test results, and digital-map data were compiled by the BOR. 


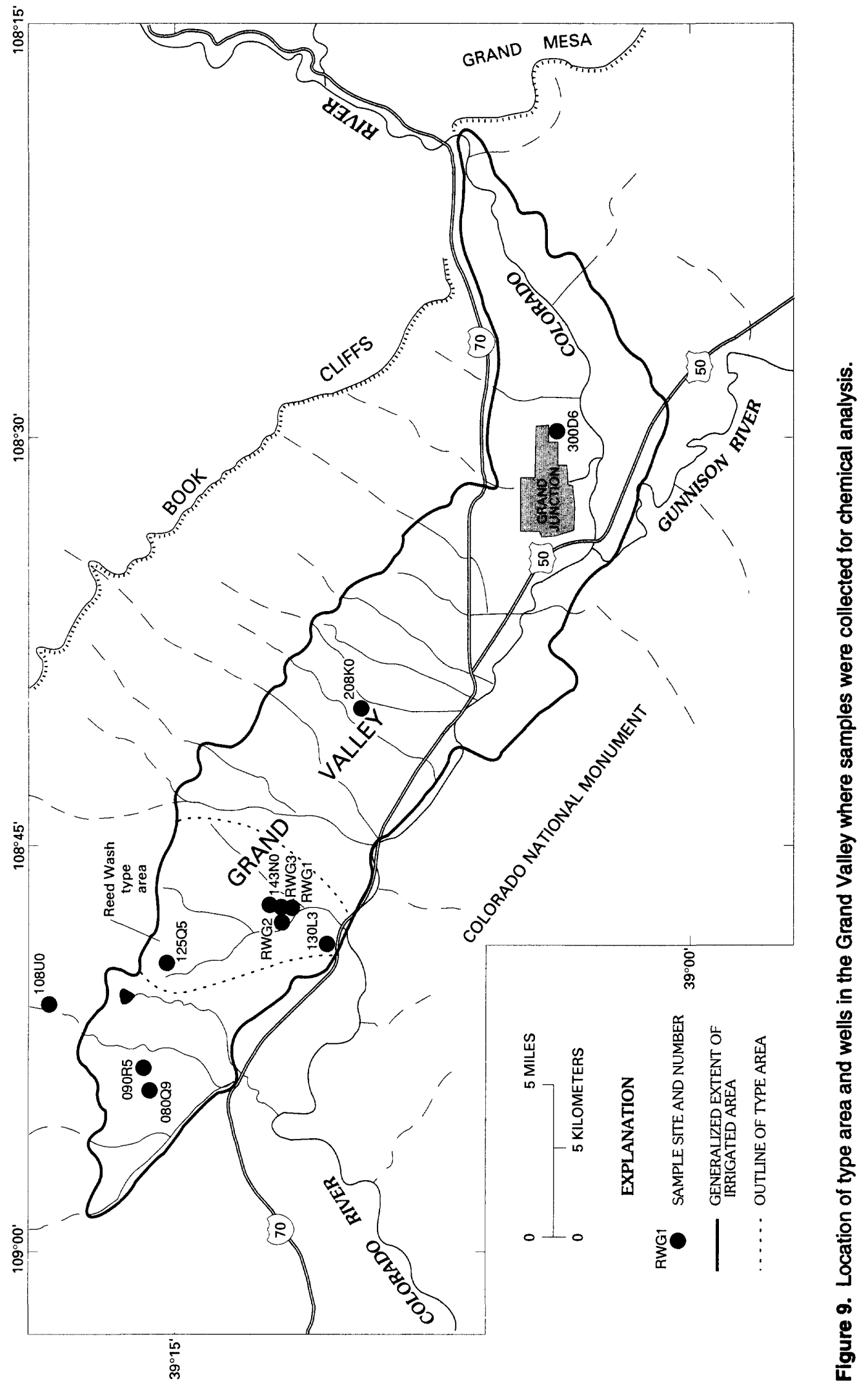




\section{Sample Collection and Analytical Methods}

Many of the shallow wells used for the groundwater investigation were installed by the $B O R$ as part of the salinity-control program in the Uncompahgre Project area and in the Grand Valley (Bureau of Reclamation, 1986a, b). Five shallow monitoring wells were installed by the USGS for this study using the hollow-stem auger method-three wells were installed in alluvium (Reed Wash type area) and two wells were installed in shale residuum (Sweitzer Lake type area). Aquifer-sediment samples were collected at 5-ft intervals using a split-spoon sampler.

Sediment-core samples for trace-element analysis were air dried, and samples for selenium-speciation analysis were frozen. After installation of 2-in. polyvinyl chloride (PVC) casing with 5-ft screens, the wells were developed by purging about 30 well volumes of water from the wells. Depths of wells in the study area (BOR, USGS, and private) ranged from 8 to $1,000 \mathrm{ft}$ below land surface.

Borehole samples were collected during installation of the shallow wells, topical samples were collected (outcrop of ash layers), and Mancos Shale bedrock-core samples were obtained from cores archived at the USGS Core Research Center in Denver, Colo. Selected sediment-core, bedrock-core, and topical samples were analyzed for (1) major and trace constituents by ICP-AES (Crock and others, 1983); (2) selenium and arsenic by continuous-flow HGAAS (Crock and Lichte, 1982; Sanzolone and Chao, 1987); (3) uranium and thorium by delayed neutron-activation counting (McKown and Mallard, 1987); and (4) total organic carbon by combustioninfrared detection (Jackson and others, 1987). Sequential extractions were performed on selected sediment-core samples (Fio and Fujii, 1990), and selenium speciation of the extraction fluids was performed by column chromatography and HGAAS (Makita and Fujii, 1992). X-ray diffraction (XRD) analyses were performed on bedrock, shale residuum, alluvium, and ground-water-filter residuum samples by L.M. Fukui (Senior Petrologist, Chem-RUST Geotech, Grand Junction, Colo.). Bedrock, shale residuum, alluvium, and ground-water-filter residuum samples were analyzed by scanning electron microscopy (SEM).

Water samples from wells and one spring were analyzed for (1) major ions, (2) selected trace constituents (including uranium), (3) nitrogen species,
(4) dissolved organic carbon, (5) stable isotopes of oxygen and hydrogen, (6) nitrogen isotopes of dissolved nitrate, (7) sulfur isotopes of dissolved sulfate, and (8) selenium species. Three to six well volumes of water were purged from the wells prior to sample collection, using a centrifugal pump. Samples were collected using a rinsed Teflon bailer and were carefully decanted into clean $1-\mathrm{L}$ polyethylene bottles, using a bottomemptying device on the bailer to prevent sample agitation and loss of volatile components (Barcelona and others, 1984). Dissolved-oxygen measurements for ground water were performed within the borehole by lowering the oxygen probe (Yellow Springs Instruments, Inc., dissolved-oxygen probe) on a cable and moving the probe vertically about $1 \mathrm{ft} / \mathrm{s}$ in the middle of the screened interval; the dissolvedoxygen meter was calibrated according to atmospheric pressure and the ambient ground-water temperature, and the meter was set to zero using a solution devoid of oxygen. Sample filtration and preservation, field-alkalinity titration, and measurement of water properties (pH, Eh, and specific conductance) were performed in a field vehicle. Oxidation-reduction potential (Eh, or redox potential) was measured using a platinum electrode, which was checked against ZoBell's solution at the ambient groundwater temperature. Water samples were filtered through a $0.45-\mu \mathrm{m}$ filter for alkalinity titrations, dissolved major-ion, nitrogen species, and traceconstituent analyses. Samples were filtered through a $0.20-\mu \mathrm{m}$ filter for sulfur-isotope and seleniumspeciation analyses. Samples collected for dissolvedorganic-carbon analyses were filtered through a $0.45-\mu \mathrm{m}$ silver filter. Samples collected for uranium and oxygen- and hydrogen-isotope analyses were unfiltered. Water samples collected for cation analyses were acidified using nitric acid to $\mathrm{pH}<2$; samples collected for nitrogen species analysis were preserved using liquid mercuric chloride; samples collected for mercury analyses were preserved using potassium dichromate; and samples collected for oxygen and hydrogen stable isotopes were preserved using mercuric chloride tablets. Water-sample filters were saved and dried for SEM and XRD analyses to describe the particulate phases that might affect ground-water quality.

A data logger was installed in one well in the Grand Valley for continuous recording of the water level and specific conductance of the ground 
water. Two wells were sampled monthly-one in Mancos Shale residuum and one in alluvium overlying Mancos Shale-to describe the seasonal effects of irrigation on trace-element concentrations in ground water.

Historical ground-water-quality and groundwater-level data were compiled by the BOR to describe the long-term effects of irrigation on ground water in the study area. Hydraulic data from historical aquifer tests performed by the BOR also were compiled by the BOR.

\section{Ground-Water Hydrology}

Ground water in the study area affected by irrigation occurs in shallow systems consisting of (1) Mancos Shale residuum, (2) alluvium overlying Mancos Shale, (3) the cobble aquifer in eastern
Grand Valley, and (4) terrace deposits in the western Uncompahgre Project area. The hydrogeologic settings, general lithologic descriptions, and general hydrogeologic characteristics of these ground-water-flow systems are described in table 4. Although the shallow systems might not have contained appreciable quantities of water in their natural (preirrigation) state, irrigation now provides substantial quantities of water for the existence of a water-table system in the shallow unconsolidated materials. The shallow groundwater systems generally discharge to local drains, streams, and rivers (fig. 10). Hydrogeologic characteristics differ greatly over short distances in the shallow system (table 4) because of the differences in composition of alluvium (which include paleochannels consisting of gravels and cobbles, fig. 10) and the differences in weathering and fracturing of the Mancos Shale.

Table 4. Hydrogeologic settings of the ground-water-flow systems affected by irrigation in the Uncompahgre Project area and in the Grand Valley

[Fm, Formation; $\mathrm{ft}$, feet; $\mathrm{n}$, number of data points; <, less than; $\mathrm{f} / \mathrm{d}$, feet per day; hydraulic-conductivity data were provided by the Bureau of Reclamation; DC, Dry Creek type area; RW, Reed Wash type area; SL, Sweitzer Lake type area; --, hydrogeologic setting not studied as a type area]

\begin{tabular}{|c|c|c|c|}
\hline $\begin{array}{l}\text { Hydrogeologic } \\
\text { setting }\end{array}$ & $\begin{array}{l}\text { Type } \\
\text { area }\end{array}$ & $\begin{array}{l}\text { Source } \\
\text { rock(s) }\end{array}$ & $\begin{array}{l}\text { General lithologic description } \\
\text { and hydrogeologic characteristics }\end{array}$ \\
\hline $\begin{array}{l}\text { Alluvium on } \\
\text { Mancos Shale }\end{array}$ & RW & $\begin{array}{l}\text { Mancos Shale, Mesaverde Fm (Grand } \\
\text { Valley); Mancos Shale, Dakota Fm, } \\
\text { San Juan Tuff, and gneisses of the } \\
\text { Black Canyon of the Gunnison and } \\
\text { Cimmaron Ridge areas (Uncompahgre } \\
\text { Valley) }\end{array}$ & $\begin{array}{l}\text { Clay, silt, sand, and gravel deposits of Holocene age. Grand Valley: } \\
\text { Erosional detritus of clay, sand, and silt; mixture of Mesaverde Fm } \\
\text { (indicated by Inoceramus and Pychnodantes fossils) and shale- } \\
\text { derived clays (smectite and illite) that might be derived from } \\
\text { mudflows. Thickness ranges from } 5 \text { to } 40 \mathrm{ft} \text {. Eastern part of } \\
\text { Uncompahgre Valley: Erosional detritus from Precambrian } \\
\text { gneisses, Oligocene tuffs, and the Dakota Fm of Cretaceous age. } \\
\text { Thickness ranges from } 5 \text { to } 25 \mathrm{ft} \text {. Hydraulic conductivities range } \\
\text { from } 8 \text { to } 140 \mathrm{ft} / \mathrm{d} \text { and average } 74 \mathrm{ft} / \mathrm{d}(\mathrm{n}=3) \text {. }\end{array}$ \\
\hline $\begin{array}{l}\text { Cobble aquifer } \\
\text { (Grand Valley) }\end{array}$ & -- & $\begin{array}{l}\text { Grand Mesa basalts, Mesaverde Fm, } \\
\text { Green River Fm, Wasatch Fm, } \\
\text { Mancos Shale }\end{array}$ & $\begin{array}{l}\text { Valley-fill deposits in an ancient valley of the Colorado River. } \\
\text { Well-sorted pebbles, cobbles, and boulders in sandy matrix; } \\
\text { alluvium and eolian sand might locally cover gravels. Late } \\
\text { Holocene to Pleistocene age. Thickness ranges from } 10 \text { to } 65 \mathrm{ft} \text {. } \\
\text { Hydraulic conductivities range from } 38 \text { to } 510 \mathrm{ft} / \mathrm{d} \text { and average } \\
190 \mathrm{ft} / \mathrm{d}(\mathrm{n}=26) \text {. }\end{array}$ \\
\hline $\begin{array}{l}\text { Terrace deposits } \\
\text { (western } \\
\text { part of the } \\
\text { Uncompahgre } \\
\text { Valley) }\end{array}$ & $\mathrm{DC}$ & $\begin{array}{l}\text { Glacial outwash and alluvium from } \\
\text { the San Juan Mountains and the } \\
\text { Uncompahgre Plateau }\end{array}$ & $\begin{array}{l}\text { Poorly sorted materials ranging from fine rock flour through sand, } \\
\text { gravel, cobbles, and boulders (Meeks, 1950). Glacial outwash } \\
\text { and alluvium of Pleistocene age locally covered by recent alluvium. } \\
\text { Thicknesses range from } 5 \text { to } 60 \mathrm{ft} \text {. Hydraulic conductivity from } \\
\text { one hydraulic test was } 650 \mathrm{ft} / \mathrm{d} \text {. }\end{array}$ \\
\hline $\begin{array}{l}\text { Mancos Shale } \\
\text { residuum }\end{array}$ & SL & Mancos Shale & $\begin{array}{l}\text { Clayey, silty residuum consisting of smectite, illite, and kaolinite } \\
\text { clays. Abundant secondary gypsum occurs in shale partings } \\
\text { and fractures; pyrite concretions altered to limonite; ash layers } \\
\text { weathered to kaolinite and quartz containing some jarosite. } \\
\text { Thickness ranges from }<1 \text { to } 100 \mathrm{ft} \text {. Hydraulic conductivities } \\
\text { range from } 4.5 \text { to } 300 \mathrm{ft} / \mathrm{d} \text { and average } 88 \mathrm{ft} / \mathrm{d}(\mathrm{n}=17) \text {. }\end{array}$ \\
\hline
\end{tabular}




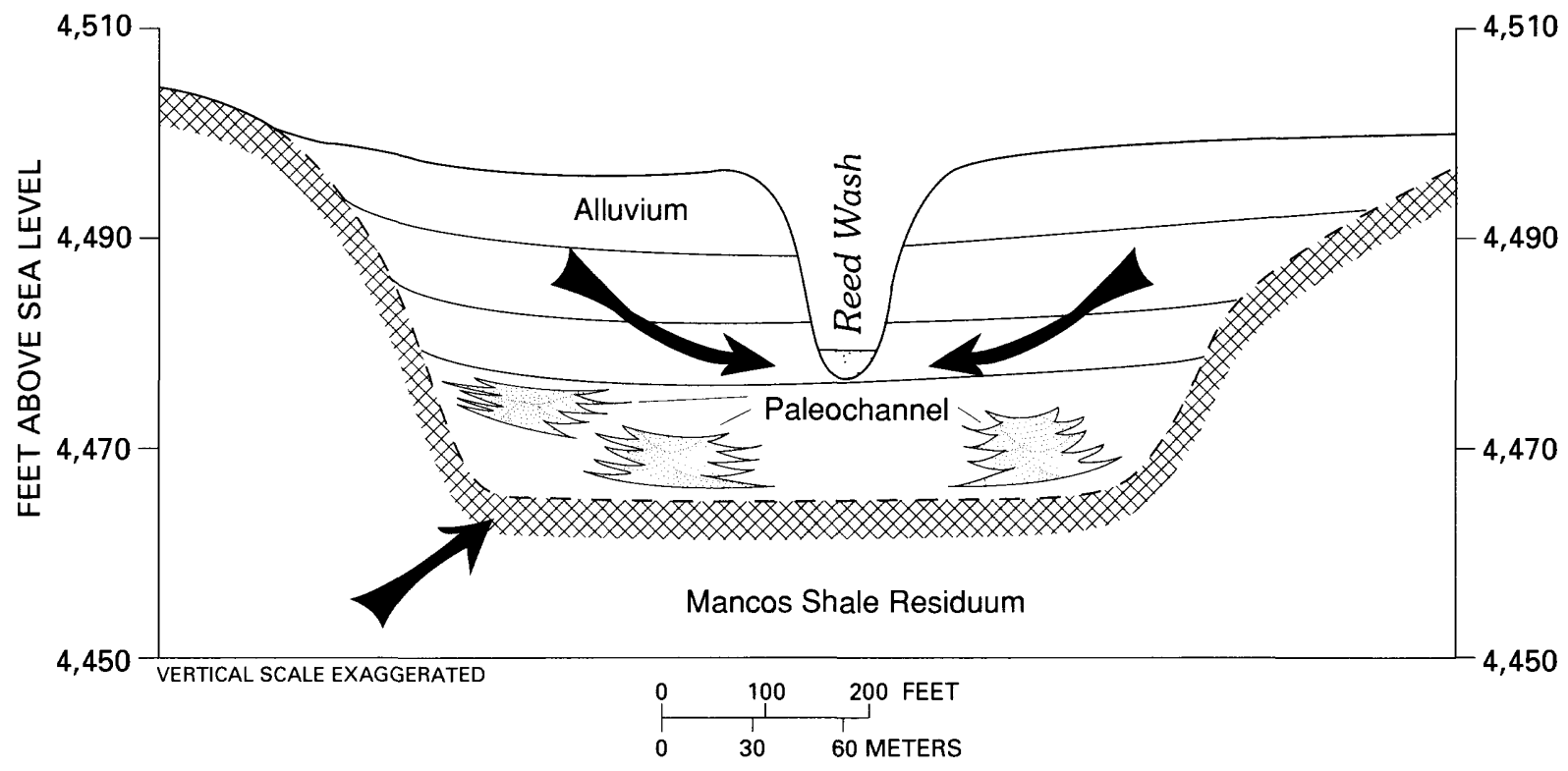

B

DRY CREEK TYPE AREA

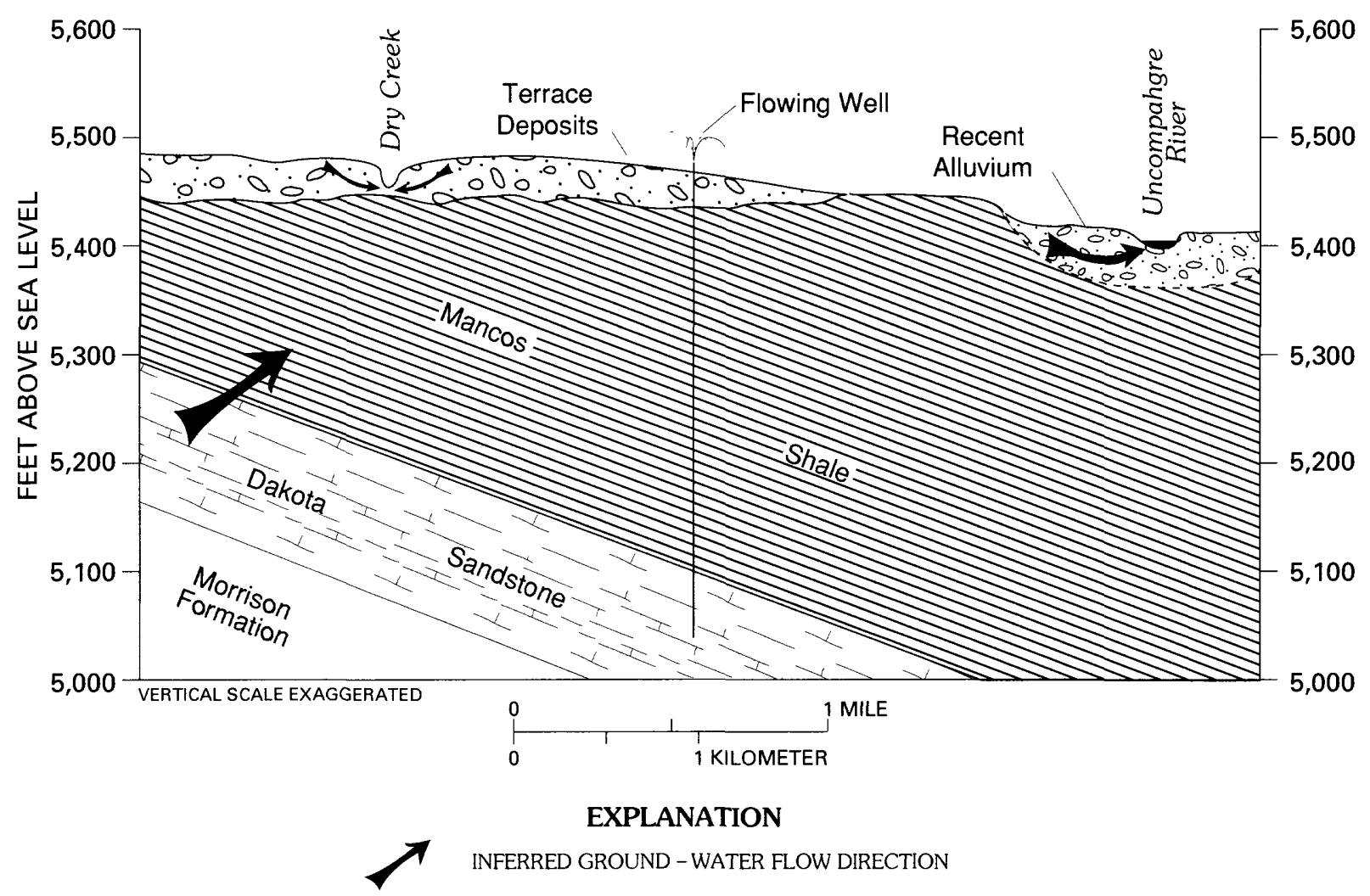

Figure 10. Schematic showing hydrogeologic setting and ground-water flow in $(A)$ Reed Wash type area and (B) Dry Creek type area. 
Deep artesian ground-water-flow systems occur in the Uncompahgre Project area (fig. 10) and in the Grand Valley. Upward ground-water flow from these artesian systems into the shallow systems is not certain, except through wells that penetrate the deep aquifers. Detailed descriptions of the deep groundwater-flow systems are reported in Meeks (1950), Lohman (1965), and Craig (1971).

Recharge to the shallow ground-water-flow system occurs through the seasonal application of irrigation water, from snowmelt during spring, and from infrequent thunderstorms during summer.

Water-level fluctuations in well 143N0 (located in the Grand Valley, fig. 9) and the fluctuations of specific conductance of ground water are shown in figure 11. Both respective traces of transducer and specificconductance data show the effects of irrigation on ground-water recharge. Water-level altitude in well $143 \mathrm{NO}$ increased during the irrigation season (April-September 1992) (fig. 11), and the water-level altitude slowly declined during the winter of 1992-93. The increase indicates storage of ground water in the shallow aquifers of the irrigated area surrounding well 143N0. Specific conductance of ground water in well 143N0 decreased during late summer and early fall (August-October 1992) (fig. 11) following the irrigation season, indicating a delayed dilution of the ground-water-quality constituents in response to irrigation recharge. Irrigation recharge occurs through leakage of unlined canals and irrigation ditches and through flood-irrigation practices in the study area. Calculations of recharge are difficult because techniques frequently used for estimating recharge (such as hydrograph separation) might not accurately represent ground-water recharge in the irrigated area where streams fluctuate greatly. However, a spring in the Sweitzer Lake type area seemed to constantly discharge about $0.25 \mathrm{gal} / \mathrm{min}$. Assuming that the discharge from the spring is constant throughout the year, a rough estimate of recharge in the 160 -acre irrigated basin is about $0.03 \mathrm{in} / \mathrm{yr}$. Snowmelt from mesas and mountains adjacent to the Uncompahgre Project area and the Grand Valley increases streamflows during early spring and recharges the natural ground-water system near intermittent streams; however, a determination of natural recharge to the ground-water system from intermittent streams was not made.

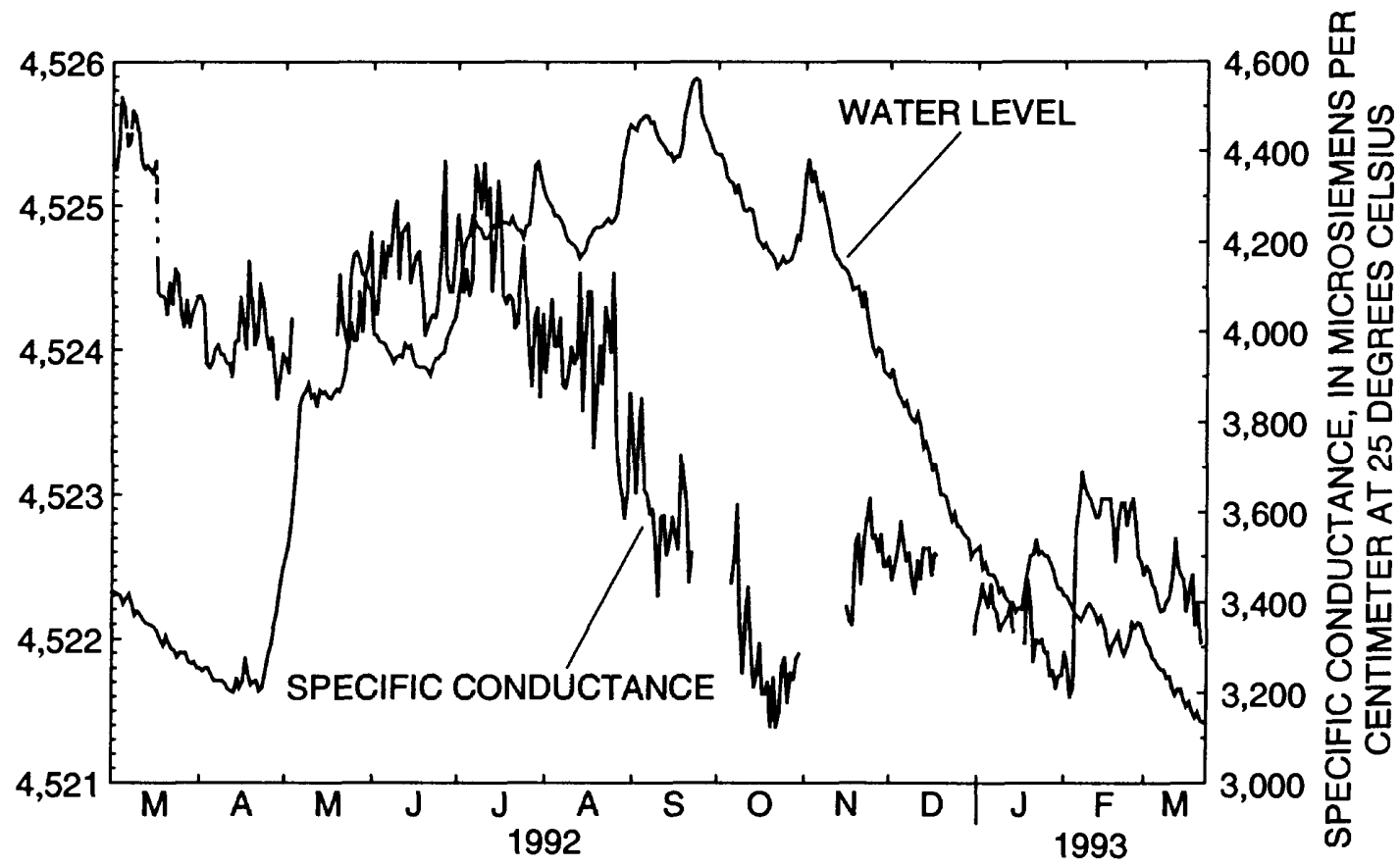

DATE, AT 1800 HOURS

Figure 11. Water-level altitude and specific conductance of water in well 143NO, Grand Valley, March 1992-March 1993. 


\section{Historical Ground-Water Quality}

As part of the salinity-control program, ground-water-quality data were collected by BOR for about 75 shallow monitoring wells installed in the Uncompahgre Project area and about 270 shallow monitoring wells installed in the Grand Valley. Major-ion data were collected annually, quarterly, and sometimes monthly during 1974-84. The BOR wells were essential for the collection of trace-element data published as part of this report.

In general, the historical ground-water-quality data (Jack Cunningham, Bureau of Reclamation, written commun., 1992) indicate high calcium, sodium, sulfate, and dissolved-solids concentrations in ground water (sources of the salinity problems). The historical ground-water-quality data indicate that high dissolved-solids concentrations are ubiquitous in areas underlain by Mancos Shale. The historical data also indicate a relation between water level in wells (reflecting the seasonal application of irrigation water) and dissolved-solids concentrations in ground water (fig. 12). When water levels rise because of irrigation, dissolved-solids concentrations in ground water decrease; when water levels fall because of cessation of irrigation in winter, dissolvedsolids concentrations in ground water increase (fig. 12). This cyclic flushing of the ground-water system has transported many soluble constituents from shallow aquifers to the streams and rivers, which could result in an eventual decrease in dissolved-solids concentrations and an eventual decline in the salinity problem; however, this effect is not evident in the 12 years of data presented for well 125Q5 (fig. 12). Ground-water-quality data are not available for the beginning of irrigation (in the 1880's in the Grand Valley); therefore, the amount of decrease in dissolved-solids concentrations in ground water since the beginning of irrigation is unknown.

\section{Major-Ion Chemistry}

Factors affecting concentrations of major ions in ground water of the Uncompahgre Project area and of the Grand Valley include: (1) The source of irrigation water; (2) dissolution, oxidation, and mobilization of major constituents in Mancos Shale, alluvium overlying Mancos Shale, and terrace deposits;

(3) oxidation-reduction state of the ground water; and (4) evaporative concentration of ground water. Because of the widespread presence of the Mancos Shale, the general quality of ground water in the study area is poor because of the calcium, sodium, and magnesium salts weathered from Mancos Shale. However, one area in the southwestern part of the Uncompahgre Project area has relatively good quality ground water because of the absence of Mancos Shale detritus in the terrace deposits. Few wells are used for drinking-water supply, and only those wells located on terrace deposits in the western part of the Uncompahgre Project area are useful for lawn irrigation. A characteristic of the poor groundwater quality is the presence of salt crust (or efflorescent minerals) evident in ground-waterdischarge zones.

The quality of the source of irrigation water differs between the two parts of the study area. Dissolved-chloride concentrations are much higher in the Colorado River, which receives sodium chloride water from hot springs, than in the Uncompahgre and Gunnison Rivers. The mean chloride concentration in ground water of the Uncompahgre Project area is $24 \mathrm{mg} / \mathrm{L}$ (13 wells) and in the Grand Valley is $262 \mathrm{mg} / \mathrm{L}$ ( 10 wells). The difference in mean chloride concentrations is caused by the different source water for irrigation.

Observations of the general characteristics of ground-water quality in the study area can be described using a water-analysis diagram (fig. 13). This diagram, sometimes referred to as a trilinear diagram or a Piper diagram, shows the relations among concentrations of cations and anions. The values are expressed as percentages of the total milliequivalents per liter of cations (lower left triangle) or of anions (lower right triangle) and are not shown as actual concentrations. The central quadrilinear graph shows the combined cationic and anionic chemical quality of the water by a third point, which is at the intersection of the rays projected from the points on the cation and anion plots. Ground water in Mancos Shale residuum and in alluvium overlying Mancos Shale predominantly is a calcium magnesium sodium sulfate water type, and water from some of the wells predominantly is a sodium sulfate water type. Water from Mancos Shale residuum tends to fall into a group different from water from the alluvium because of the difference in percentages of sodium (the mean sodium concentration in Mancos Shale residuum is $630 \mathrm{mg} / \mathrm{L}$, and the mean in alluvium overlying Mancos Shale is $350 \mathrm{mg} / \mathrm{L}$ ). 


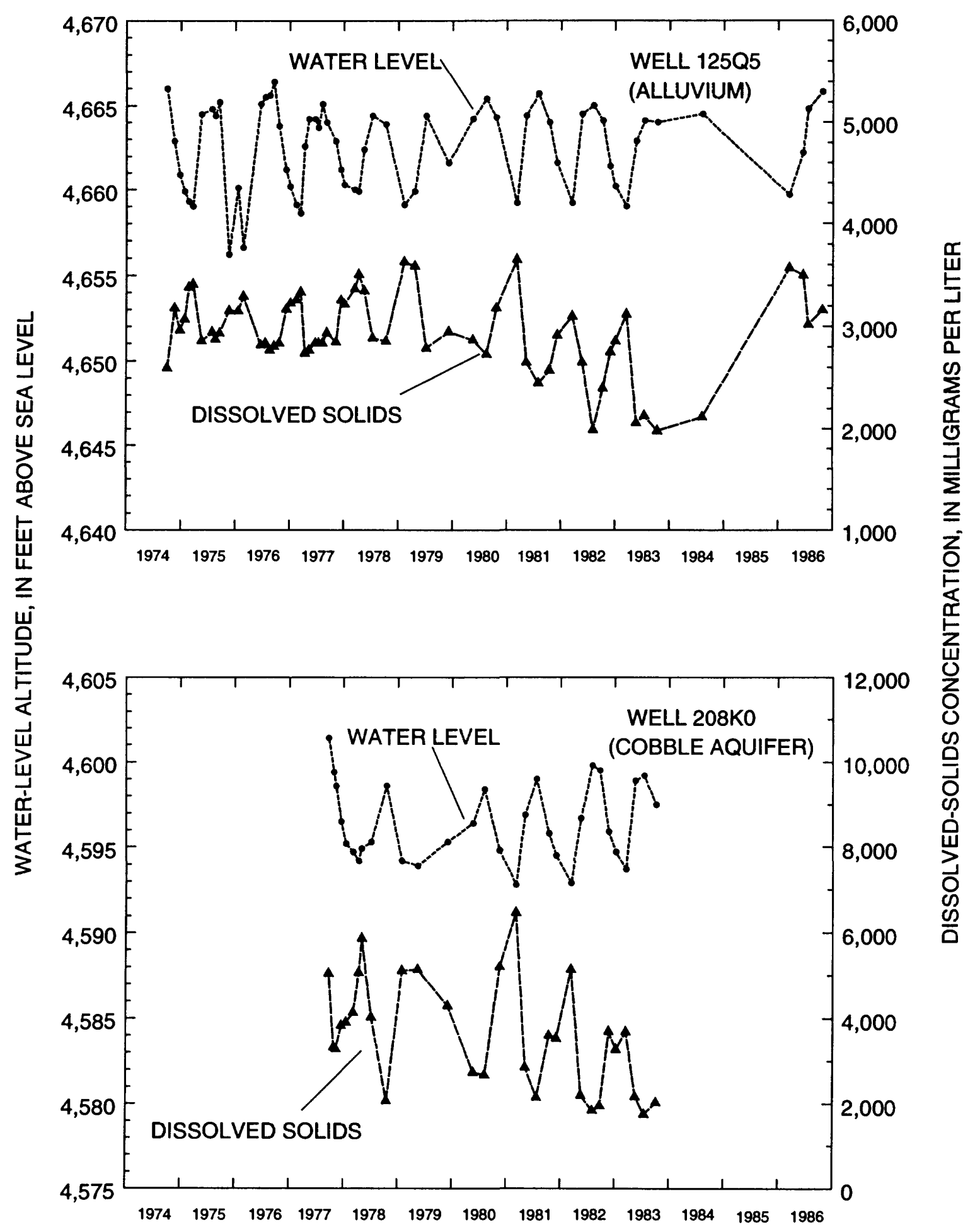

Figure 12. Historical water-level altitudes and dissolved-solids concentrations in water from wells $125 \mathrm{Q} 5$ and 208KO located in the Grand Valley (Jack Cunningham, Bureau of Reclamation, written commun., 1992). 


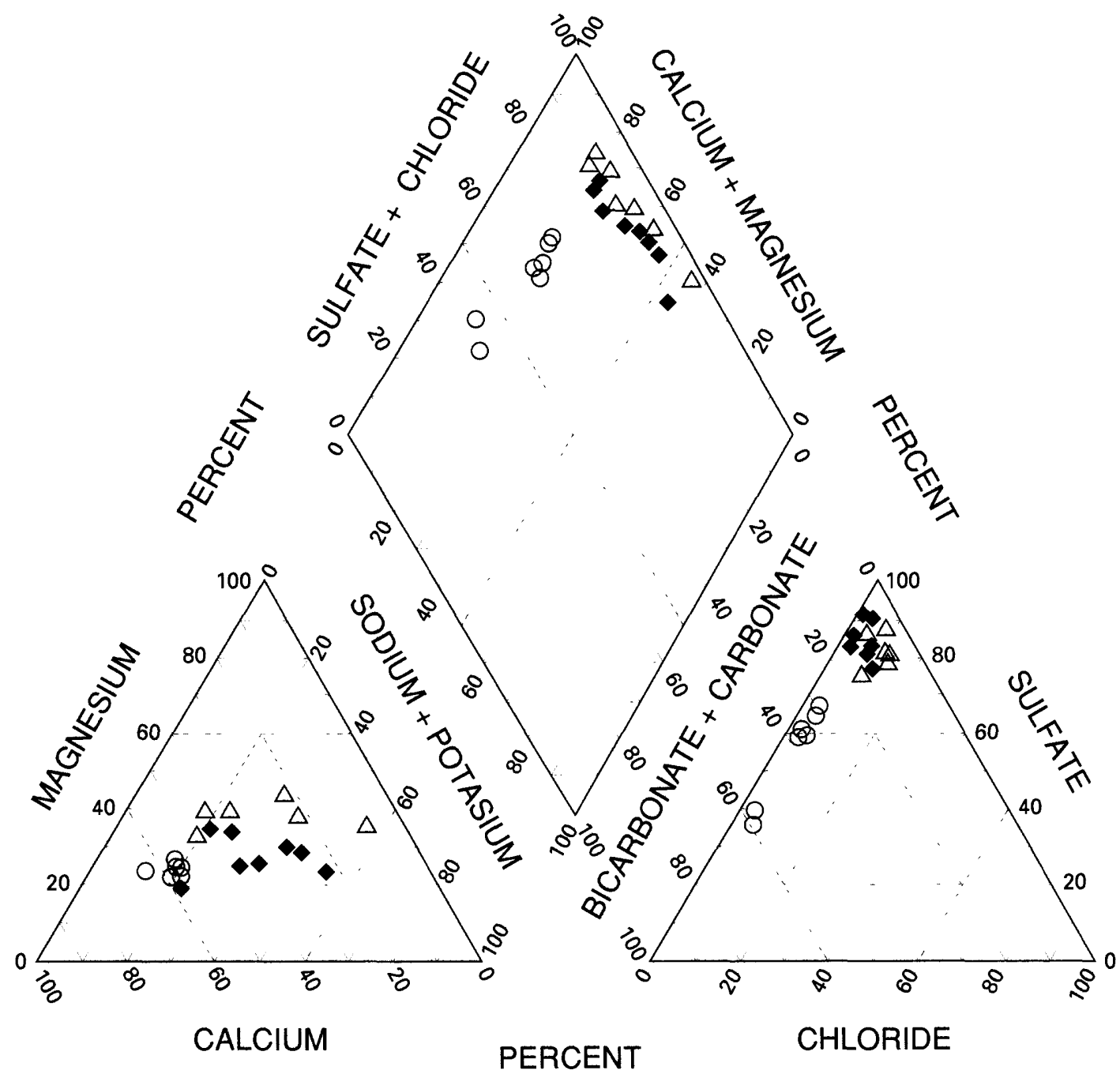

\section{EXPLANATION}

WATER FROM WELL IN MANCOS SHALE RESIDUUM

MEAN DISSOLVED-SOLIDS CONCENTRATION $=5,270$ MILLIGRAMS PER LITER MEAN pH $=6.93$

$\triangle \quad$ WATER FROM WELL IN ALLUVIUM OVERLYING MANCOS SHALE MEAN DISSOLVED-SOLIDS CONCENTRATION $=4,730$ MILLIGRAMS PER LITER MEAN pH $=6.94$

WATER FROM WELL IN TERRACE DEPOSITS, WESTERN PART OF THE UNCOMPAHGRE PROJECT AREA

MEAN DISSOLVED-SOLIDS CONCENTRATION $=810$ MILLIGRAMS PER LITER MEAN pH $=7.15$

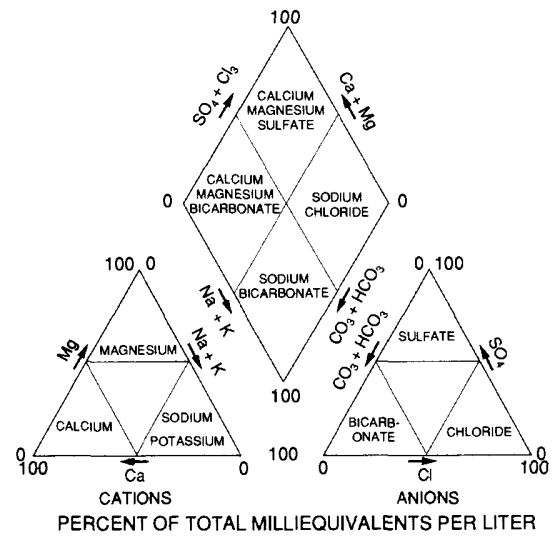

Figure 13. Trilinear diagram showing percentages of major ions in water from selected wells during the irrigation season in the Uncompahgre Project area and in the Grand Valley. 
Water from wells in terrace deposits in the western Uncompahgre Project area was distinctly different, being predominantly a calcium sulfate tending toward a calcium bicarbonate water type. The mean dissolved-solids concentrations additionally describe differences in water quality between the different hydrogeologic settings. Water in Mancos Shale residuum and in alluvium overlying Mancos Shale had a mean dissolved-solids concentration of $5,270 \mathrm{mg} / \mathrm{L}$ and $4,730 \mathrm{mg} / \mathrm{L}$, respectively. Water in terrace deposits on the western part of the Uncompahgre Project area had a mean dissolved-solids concentration of $810 \mathrm{mg} / \mathrm{L}$.

The thermodynamic equilibrium speciation of major dissolved constituents in ground water of the study area was determined using the geochemical speciation program WATEQ4F (Ball and Nordstrom, 1991). Saturation indices are listed for different mineral compounds that were in the aqeuous phase (table 5); saturation indices greater than zero indicated oversaturation (and possible precipitation of that mineral), and values less than zero indicated undersaturation (where that mineral could continue to dissolve). Ground water in Mancos Shale residuum and alluvium overlying Mancos Shale is near saturation or oversaturated with calcite, aragonite, dolomite, gypsum, ferrihydrite, and quartz. Ground water in terrace deposits is near saturation or oversaturated only with calcite, ferrihydrite, and quartz. Mineral species in ground water of the study area identified by the model are similar to the evaporite mineral species identified by Whittig and others (1982) in salt efflorescence samples collected from the Grand Valley (table 6).

Evapotranspiration can affect ground-water quality by concentrating major ions and trace constituents-called evaporative concentration. Effects of evapotranspiration on ground-water recharge could be great in the Uncompahgre Project area and in the Grand Valley because annual precipitation averages about 8 to $10 \mathrm{in} / \mathrm{yr}$, and estimates of pan evaporation range from 40 to $50 \mathrm{in} / \mathrm{yr}$. However, the effects of evaporative concentration in the Uncompahgre Project area and in the Grand Valley are not great, based on data for oxygen and hydrogen stable-isotope values (fig. 14). When $\delta^{18} \mathrm{O}$ [or the O-18/O-16 stable-isotope ratio referenced to the Vienna Standard Mean Ocean Water (VSMOW)] and $\delta^{2} \mathrm{H}$ (or the $\mathrm{H}-2 / \mathrm{H}-1$ stable-isotope ratio referenced to the VSMOW) from surface and ground water are plotted on one graph for the Uncompahgre Project area and the Grand Valley, the data plot near and parallel to the meteoric water line (Gat, 1981) and do not indicate an evaporation trend. When plotted separately by area, a slight evaporation trend is indicated by the data; however, outliers from one well in the Grand Valley seem to skew the results (fig. 14). The meteoric water line is described by $\delta^{2} \mathrm{H}=8 \delta^{18} \mathrm{O}+10$ (Gat, 1981). The evaporation line for the Uncompahgre Project area can be defined by $\delta^{2} \mathrm{H}=6.7 \delta^{18} \mathrm{O}-12.4$ $\left(r^{2}=0.89\right)$; the evaporation line for the Grand Valley can be defined by $\delta^{2} \mathrm{H}=4.2 \delta^{18} \mathrm{O}-53.9\left(\mathrm{r}^{2}=0.71\right)$. The differences in the groupings of data points for the two areas might be related to precipitation used for irrigation water falling and being stored at different altitudes of the Rocky Mountains and being affected by reservoir evaporation, particularly in the Gunnison River Basin (data for the Uncompahgre Project area). Effects of evaporative concentration on ground water are evident in water from a few wells inside and in water from a well located outside the irrigated area; however, in general, evaporative concentration is not a major factor in ground-water quality in the irrigated areas. The effects of evaporation might not be great in the study area because flood-irrigation practices keep the system well flushed, and the relatively steep terrain provides rapid drainage of the shallow ground-water system compared to other irrigation-drainage study areas, such as the broad sedimentary basin of the San Joaquin Valley, Calif. (Deverel and others, 1984; Dubrovsky and others, 1990).

\section{Review of Selenium Geochemistry}

Selenium is known to have volcanic, magmatic, and hydrothermal sources (Trelease and Beath, 1949; Coleman and Delevaux, 1957; Sindeeva, 1964; Howard, 1977) and is present in relation to hydrothermal and roll-type uranium deposits (Sindeeva, 1964; Fishman and others, 1985; Fishman and Reynolds, 1986). Selenium enrichment of geologic materials occurred during the Cretaceous age and was related to volcanic emanations of element-rich gases and ashes. Volcanic detritus was ultimately deposited in the Cretaceous sea that covered much of the interior of North America. The organic-rich reducing environment of the Cretaceous sea bottom was capable of precipitating sulfide minerals, such as pyrite $\left(\mathrm{FeS}_{2}\right)$ and chalcopyrite $\left(\mathrm{CuFeS}_{2}\right)$. Because selenium is isomorphous with sulfur, selenium substituted for sulfur in the crystalline structure of sulfide minerals in the Cretaceous shales. 


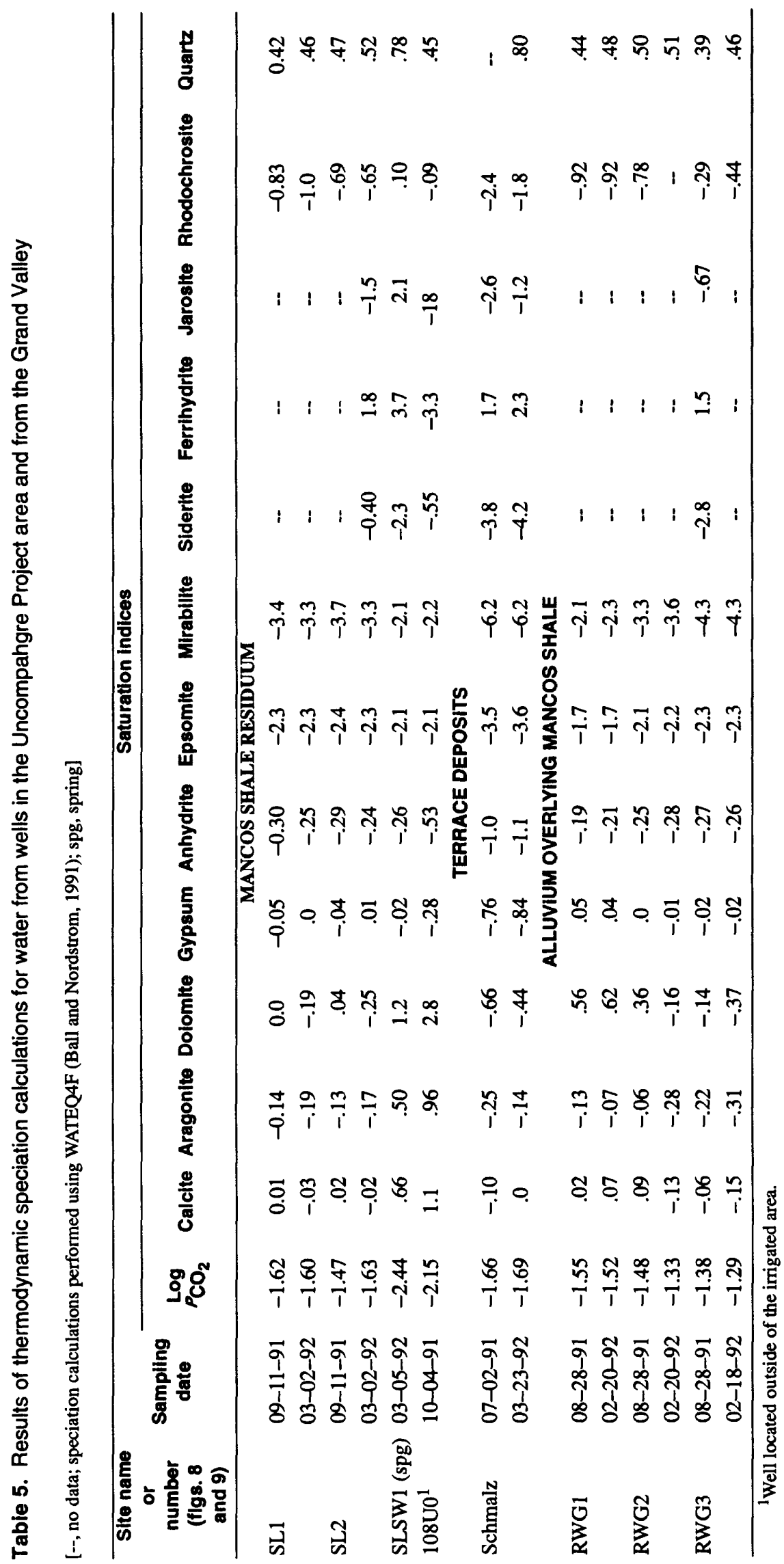


Selenium, therefore, might be directly related to volcanic-ash layers in Cretaceous shales. In contrast, Sindeeva (1964, p. 290-291) indicated that selenium was present in sizable amounts in recent sea-bottom sediments and could be precipitated directly from river water entering the oceans, but these recent selenium concentrations in ocean sediment also could be attributed to the burning of fossil fuels (particularly coal), which puts trace concentrations of selenium into the atmosphere, lakes, rivers, and oceans.

Table 6. Evaporite mineral species and salt efflorescence associated with the Mancos Shale and shale residuum in the Grand Valley (from Whittig and others, 1982)

[X, mineral species identified; --, mineral species not identified]

\begin{tabular}{|c|c|c|}
\hline $\begin{array}{c}\text { Evaporite } \\
\text { species }\end{array}$ & $\begin{array}{l}\text { Occurring } \\
\text { in } \\
\text { Mancos } \\
\text { Shale }\end{array}$ & $\begin{array}{l}\text { Occurring } \\
\text { in } \\
\text { efflores- } \\
\text { cence }\end{array}$ \\
\hline Gypsum $\left(\mathrm{CaSO}_{4} \cdot 2 \mathrm{H}_{2} \mathrm{O}\right)$ & $\mathbf{X}$ & $\mathbf{X}$ \\
\hline Epsomite $\left(\mathrm{MgSO}_{4} \cdot 10 \mathrm{H}_{2} \mathrm{O}\right)$ & - & $\mathbf{X}$ \\
\hline Hexahydrite $\left(\mathrm{MgSO}_{4} \bullet 6 \mathrm{H}_{2} \mathrm{O}\right)$ & -- & $\mathbf{X}$ \\
\hline Pentahydrite $\left(\mathrm{MgSO}_{4} \cdot 5 \mathrm{H}_{2} \mathrm{O}\right)$ & -- & $\mathbf{X}$ \\
\hline Starkeyite $\left(\mathrm{MgSO}_{4} \bullet 4 \mathrm{H}_{2} \mathrm{O}\right)$ & -- & $\mathbf{X}$ \\
\hline Kieserite $\left(\mathrm{MgSO}_{4} \bullet \mathrm{H}_{2} \mathrm{O}\right)$ & -- & $\mathbf{X}$ \\
\hline Mirabilite $\left(\mathrm{Na}_{2} \mathrm{SO}_{4} \cdot 10 \mathrm{H}_{2} \mathrm{O}\right)$ & -- & $\mathbf{X}$ \\
\hline Thenardite $\left(\mathrm{Na}_{2} \mathrm{SO}_{4}\right)$ & -- & $\mathbf{X}$ \\
\hline Loewite $\left[\mathrm{Na}_{4} \mathrm{Mg}_{2}\left(\mathrm{SO}_{4}\right)_{4} \cdot 5 \mathrm{H}_{2} \mathrm{O}\right]$ & -- & $\mathbf{X}$ \\
\hline Bloedite $\left[\mathrm{Na}_{2} \mathrm{Mg}\left(\mathrm{CO}_{4}\right)_{2} \bullet 4 \mathrm{H}_{2} \mathrm{O}\right]$ & -- & $\mathbf{X}$ \\
\hline
\end{tabular}

Selenium is present as a trace constituent in pyrite in the Mancos Shale within the study area; concentrations range from 0.003 to 1.6 percent (Coleman and Delevaux, 1957). When the Mancos Shale is exposed to weathering, selenium weathers (or is oxidized) from pyrite (where the selenium has a valence state of -2 ) to further transformations in valence state $(-2 \rightarrow 0 \rightarrow+4 \rightarrow+6)$ that become increasingly more soluble with increasing valence: elemental selenium ( $\mathrm{Se}^{0}$, selenium valence of 0 ), selenite $\left(\mathrm{Se}^{\mathrm{IV}} \mathrm{O}_{3}{ }^{2-}\right.$, selenium valence of +4$)$, biselenite $\left(\mathrm{HSe}^{\mathrm{IV}^{-}}{ }_{3}^{-}\right.$, selenium valence of +4$)$, and selenate $\left(\mathrm{Se}^{\mathrm{VI}} \mathrm{O}_{4}{ }^{2-}\right.$, selenium valence of +6$)$. The oxidation of selenium compounds can be represented by the following half reactions:

$\mathrm{Se}^{0}+3 \mathrm{H}_{2} \mathrm{O} \quad \leftrightarrow \quad \mathrm{Se}^{\mathrm{IV}} \mathrm{O}_{3}{ }^{2-}+6 \mathrm{H}^{+}+4 \mathrm{e}^{-} \mathrm{E}^{0}=-0.875 \mathrm{mV}$

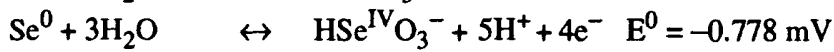

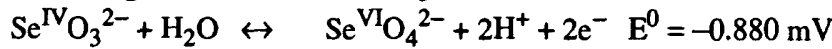
$\mathrm{HSe}^{\mathrm{IV}} \mathrm{O}_{3}{ }^{-}+\mathrm{H}_{2} \mathrm{O} \leftrightarrow \quad \mathrm{Se}^{\mathrm{VI}} \mathrm{O}_{4}{ }^{2-}+3 \mathrm{H}^{+}+2 \mathrm{e}^{-} \mathrm{E}^{0}=-1.075 \mathrm{mV}$

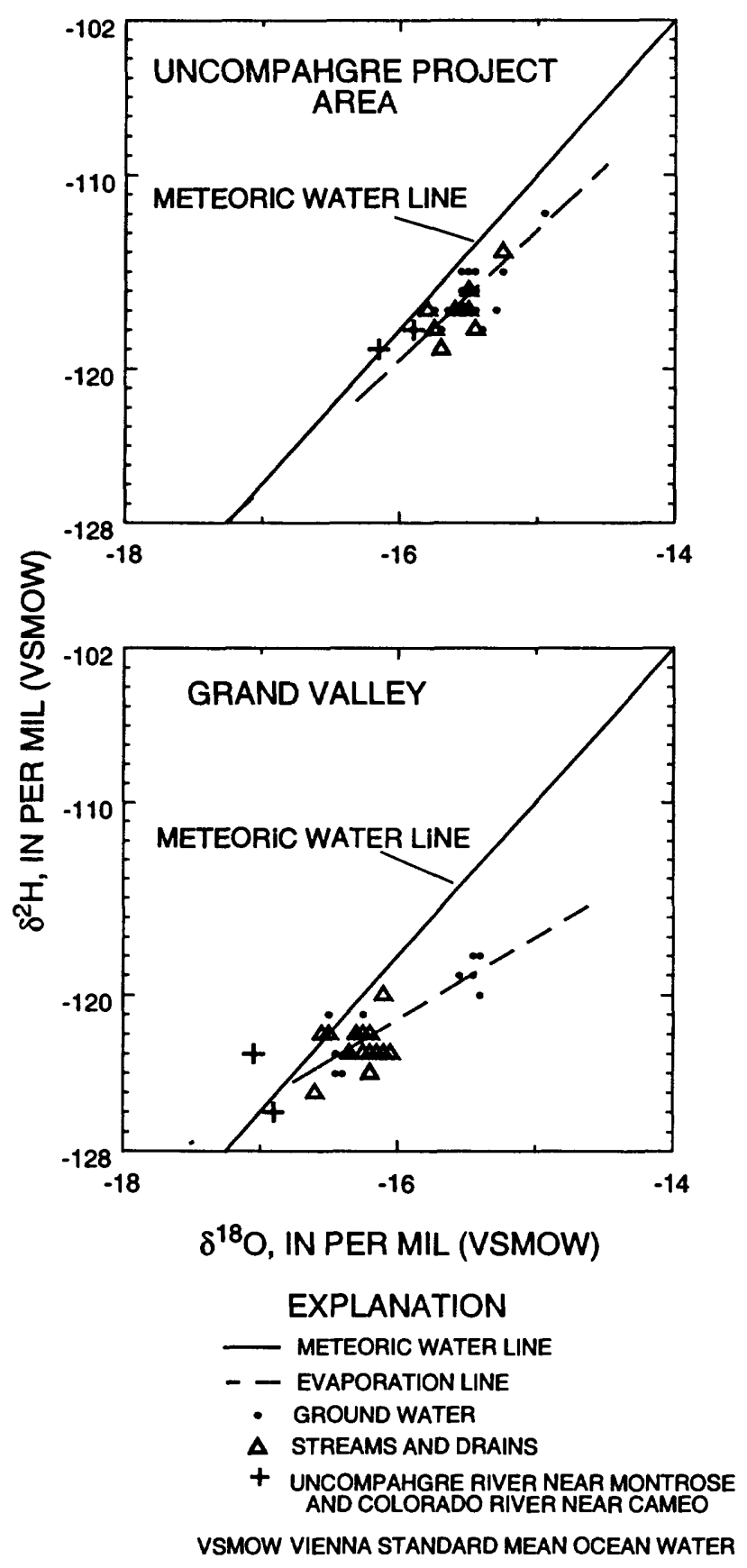

Figure 14. Oxygen and hydrogen stable isotope values in water from selected wells, streams, and rivers in the Uncompahgre Project area and in the Grand Valley.

The species that are present in solution after oxidation of reduced selenium species primarily are a function of the $\mathrm{pH}$ and the oxidation-reduction potential (Eh-pH) of the geochemical environment (fig. 15). Selenite ( $\mathrm{Se}^{\mathrm{IV}} \mathrm{O}_{3}{ }^{2-}$ ) and biselenite $\left(\mathrm{HSe}^{\mathrm{IV}} \mathrm{O}_{3}{ }^{-}\right.$) readily adsorb to aquifer sediments or coprecipitate with ferric oxyhydroxide complexes, 
and selenate $\left(\mathrm{Se}^{\mathrm{VI}} \mathrm{O}_{4}{ }^{2-}\right.$ ) is very soluble and is easily transported in an oxidized hydrologic system (Howard, 1977; Electric Power Research Institute, 1980; Balistrieri and Chao, 1987; Bar-Yosef and Meek, 1987). Selenate can adsorb to aquifer sediments, but selenate forms an outer-layer complex (more easily desorbed) with iron oxides, whereas selenite forms an inner-layer complex (less easily desorbed) with iron oxides (Hayes and others, 1987). These adsorption processes are completely reversible (Electric Power Research Institute, 1980; Balistrieri and Chao, 1987), indicating that selenium could be desorbed from clay and mineral surfaces and put back into solution.

Previous studies have been published about the distribution of selenium in the San Joaquin Valley, California. Sources of dissolved selenium in ground and surface water in the San Joaquin Valley were hypothesized to be sulfides in shale (the Moreno Formation of Cretaceous age) of the Coast Range of
California (Presser and others, 1990) and sediments of the west-central San Joaquin Valley derived from Coast Range rocks (Deverel and others, 1984; Gilliom, 1989; Izbicki, 1989). Studies by Deverel and Millard (1988) and by Fujii and Deverel (1989) concluded that high concentrations of selenium in ground and surface water were a result of evaporative concentration of ground water, which was indicated by isotopic enrichment of oxygen and hydrogen stable isotopes and by correlation of elevated selenium concentrations with ground-water salinity. The hydrogeochemical processes involved in the immobilization of selenium from the aqueous phase has been the focus of several studies (Dubrovsky and others, 1990; Masscheleyn and others, 1991; Sposito and others, 1991; White and others, 1991). The wellaccepted conclusions of these studies are that dissolved selenium primarily occurs in the selenate form and is transported to deeper zones (10 to $50 \mathrm{ft}$ ) of reducing geochemical environments where selenium

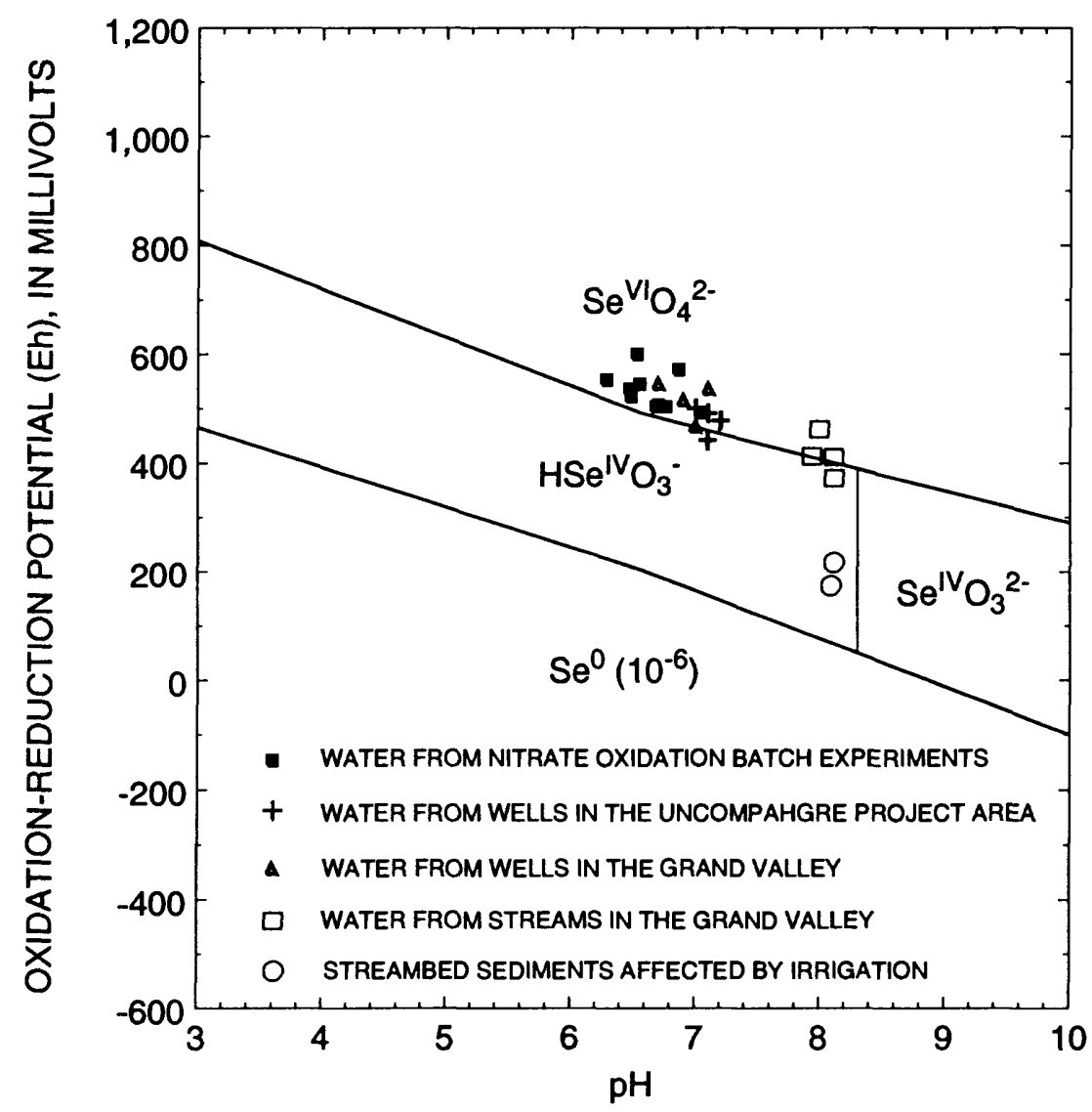

Figure 15. Stability-field diagram for selenium species in natural waters and data points calculated from selenium-speciation data collected for this study. Thermodynamic data are from Garrels and Christ (1965) and from P.F. Bell and D.R. Parker (University of California, Riverside, written commun., 1991). 
is reduced to the less mobile selenite and elemental selenium species. Hypotheses for mobilization and transport of selenium by oxidation-reduction and adsorption/desorption processes were described, and the platinum-electrode potential was observed to be an important parameter for recognizing geochemical conditions suitable for the reduction of selenium.

Selenium can be absorbed from some soils by food and forage plants in sufficient amounts to make them highly poisonous to animals. Several native range plants of the Western United States require selenium and can uptake selenium in concentrations as high as 15,000 parts per million (Trelease and Beath, 1949, p. 85); however, the concentrations of selenium in the plants vary according to seasonal growth and development (Beath and others, 1937). Several of these native plants (for example, Astragalus bisulcatus, Stanleya bipinnata, Xylorhiza parryi, and Oonopsis condensata) are called primary indicators for the presence of highly seleniferous soils. Other native plants tolerate selenium and are called secondary indicators. The presence of seleniumindicator plants is significant enough to allow the mapping of selenium-bearing geological formations from the recognition of these plants. The uptake of selenium by farm crops differs by species, soil pH, soil texture, and soil organic matter; however, certain grains and hay grown on seleniferous soils can uptake selenium in concentrations high enough to be deleterious to animal health. Selenium accumulation in farm crops generally ranges from greatest to least in root and bulb crops, field crops, leafy vegetables, seed vegetables, vegetable fruits, and tree fruits (Mikkelson and others, 1989, p. 74).

According to Trelease and Beath (1949), native seleniferous vegetation is widely distributed in Colorado. Most of the seleniferous plants have been collected on formations of Cretaceous age. The Dakota, Mesaverde, and McDermott Formations (sandstones) have plants with the lowest selenium concentrations. The Mancos Shale, Greenhorn, and Benton Formations bear plants with medium concentrations of selenium, and the Pierre Shale and Niobrara Formation produce highly seleniferous vegetation. Seleniferous plants are capable of converting inorganic selenium (probably as $\mathrm{Se}^{0}, \mathrm{Se}^{\mathrm{IV}} \mathrm{O}_{3}{ }^{2-}$, or $\mathrm{Se}^{\mathrm{VI}} \mathrm{O}_{4}{ }^{2-}$ ) into organic selenium (such as selenomethionine, selenocysteine, and selenocystine), transforming the selenium into a much more toxic form (Thompson-Eagle and Frankenberger, 1992).
Microbiological processes might be important for transformation of selenium species. Bacteria and fungi can volatilize $\mathrm{Se}^{0}, \mathrm{SeO}_{3}{ }^{2-}, \mathrm{SeO}_{4}{ }^{2-}$, and organoselenides into mobile methylated derivatives, such as dimethylselenide and dimethyl diselenide (Frankenberger and Karlson, 1992; Thompson-Eagle and Frankenberger, 1992). Selenium reduction and volatilization have been studied as possible mitigative measures to ameliorate seleniumcontaminated agricultural drainwater. Oxidized forms of selenium (such as mobile aqueous $\mathrm{SeO}_{4}{ }^{2-}$ ) can be reduced to less mobile forms $\left(\mathrm{Se}^{0}\right.$ and $\mathrm{SeO}_{3}{ }^{2-}$ ) by anaerobic bacteria (Oremland, Hollibaugh, and others, 1989; Oremland and others, 1990; Steinberg and Oremland, 1990). Reduced selenium species can be oxidized by autotrophic bacteria (Lipman and Waksman, 1922; Sarathchandra and Watkinson, 1981); however, little work has been performed to investigate the mechanisms involved in selenium oxidation (Sarathchandra and Watkinson, 1981; Thompson-Eagle and Frankenberger, 1992).

In summary, at least four processes-oxidationreduction, adsorption/desorption, vegetative uptake and transformation, and microbial mediation-could affect selenium speciation and concentrations in natural water and in the environment. Reduction originally played a role in precipitation of sulfide minerals (incorporating trace concentrations of selenium) possibly related to volcanic-ash-layer deposits in Cretaceous geological formations. Uplift and emergence exposed the shale to natural weathering that oxidized the sulfides and released selenium into the environment. Irrigation is speeding up the weathering process in which selenium is mobilized in the hydrologic environment.

\section{Sources of Selenium and Other Trace Constituents}

Core samples of Mancos Shale, Mancos Shale residuum, and alluvium were collected from the study area and were analyzed to determine the concentrations of selenium and other trace constituents in the solid-phase samples (table 7). Selenium is isomorphous with sulfur and substitutes in the crystalline structure of sulfide minerals (Coleman and Delevaux, 1957); therefore, core samples were collected to describe the relation of sulfide mineralization (and the source of selenium) to depositional environment in the Mancos Shale. Disseminated sulfides in the Mancos 
Shale core range in size from 0.01 to $0.05 \mathrm{~mm}$ viewed under 20X microscope. The disseminated sulfides almost always are associated with darker layers (organic-rich lenses) in shale bedrock. Sulfide euhedrons ( 0.1 to $0.5 \mathrm{~mm}$ ) occur immediately adjacent to the bottom side of ash layers that were examined in core. XRD and SEM analyses of sulfide-mineral euhedrons adjacent to ash layers indicate that the sulfides in this part of the Mancos Shale are pyrite (table 7).

The selenium concentration in a Mancos Shale bedrock sample (representing disseminated pyrite) was $0.8 \mu \mathrm{g} / \mathrm{g}$, selenium concentration in one ash-layer sample was less than the reporting limit $(<0.1 \mu \mathrm{g} / \mathrm{g})$, and selenium concentration in one pyrite sample adjacent to the bottom side of an ash layer was $19 \mu \mathrm{g} / \mathrm{g}$ (table 8). Coleman and
Delevaux (1957) tabulated selenium concentrations from sulfides in the Mancos Shale ranging from 0.002 to 1.6 percent ( 2 to $1,600 \mu \mathrm{g} / \mathrm{g}$ ).

Analyses of trace-element concentrations in shale residuum and weathered ash indicate that more selenium and uranium were contained in the weathered ash sample than in shale residuum and bedrock samples. XRD analyses of weathered ash indicate that the dominant clay minerals are kaolinite and smectite (table 7). Bar-Yosef and Meek (1987) and Balistrieri and Chao (1987) indicated that selenium is readily adsorbed by kaolinite and smectite. Kaolinite is present in shale residuum and alluvium (table 7), and smectite is present in weathered ash. These clay minerals adsorb trace constituents and could be sources for the leaching of selenium and other trace constituents.

Table 7. Semiquantitative clay and bulk mineralogy of Mancos Shale bedrock core, shale residuum, alluvium, and ground-water-filter residuum (L.M. Fukui, Chem-Nuclear Geotech, written commun., 1992)

[III/Smec, illite/smectite; nd, not detected; tr, less than 7 percent of intensity of dominant phase; min, 7 to 30 percent of intensity of dominant phase; mod, 30 to 70 percent of intensity of dominant phase; dom, predominant mineral in X-ray pattern; sdom, 70 to 99 percent of intensity of dominant phase; cdom, predominant minerals have same relative intensities; P, plagioclase; K, potassium; ft BLS, feet below land surface]

\begin{tabular}{llllll}
\multicolumn{1}{c}{$\begin{array}{c}\text { Sample } \\
\text { description }\end{array}$} & Ilite & IIVSmec & Kaolinite & Smectite & Chiorite \\
\hline Mancos Shale bedrock & nd & tr & min & min & tr? \\
Sulfide euhedron from core & nd & nd & nd & nd & nd \\
Ash layer from core & nd & min & min & mod & min? \\
Weathered ash layer & nd & nd & dom & sdom & nd \\
Residuum, SL1, 5 ft BLS & cdom & min & cdom & min & tr \\
Residuum, SL1, 15.5 ft BLS & cdom & tr & cdom & min & tr \\
Alluvium, RWG1, $6 \mathrm{ft} \mathrm{BLS}$ & cdom & mod & cdom & tr & tr \\
Alluvium, RWG1, 24.5 ft BLS & cdom & mod & cdom & tr & tr \\
\hline \hline
\end{tabular}

\begin{tabular}{|c|c|c|c|c|c|c|c|}
\hline \multirow{2}{*}{$\begin{array}{c}\text { Sample } \\
\text { description }\end{array}$} & \multirow{2}{*}{ Quartz } & \multicolumn{2}{|c|}{ Feldspar } & \multirow{2}{*}{ Calcite } & \multirow{2}{*}{ Dolomite } & \multirow{2}{*}{ Gypsum } & \multirow{2}{*}{ Pyrite } \\
\hline & & $\mathbf{P}$ & $\mathbf{K}$ & & & & \\
\hline Mancos Shale bedrock & dom & $\operatorname{tr}$ & nd & $\min$ & nd & nd & nd \\
\hline Sulfide euhedron from core & nd & nd & nd & nd & nd & nd & dom \\
\hline Ash layer from core & dom & nd & nd & tr? & nd & nd & nd \\
\hline Weathered ash layer & $\bmod$ & nd & nd & nd & $\operatorname{tr}$ & nd & nd \\
\hline Residuum, SL1, $5 \mathrm{ft}$ BLS & sdom & $\operatorname{tr}$ & $\operatorname{tr}$ & $\min$ & $\min$ & dom & nd \\
\hline Residuum, SL1, $15.5 \mathrm{ft}$ BLS & dom & tr & $\operatorname{tr}$ & $\min -\bmod$ & $\min$ & nd & nd \\
\hline Alluvium, RWG1, $6 \mathrm{ft}$ BLS & dom & $\min$ & $\operatorname{tr}$ & $\min$ & $\min$ & nd & nd \\
\hline Alluvium, RWG1, $24.5 \mathrm{ft}$ BLS & dom & tr & nd & $\bmod$ & $\min -\bmod$ & $\operatorname{tr}$ & nd \\
\hline Alluvium, RWG1, $27.5 \mathrm{ft}$ BLS & sdom & tr & $\operatorname{tr}$ & dom & $\min$ & nd & tr \\
\hline Ground-water-filter residuum ${ }^{1}$ & dom & $\min -\mathrm{tr}$ & nd & $\min -\mathrm{tr}$ & $\min -\mathrm{tr}$ & nd & $\operatorname{tr}$ \\
\hline
\end{tabular}

\footnotetext{
${ }^{1}$ Well 108U0, which is completed in shale residuum and located outside the irrigated area.
} 
Table 8. Element and organic-carbon concentrations in soil and rock samples from the Uncompahgre Project area and from the Grand Valley

[Se, selenium; U, uranium; V, vanadium; Fe, iron; $\mu \mathrm{g} / \mathrm{g}$, micrograms per gram, which is equivalent to parts per million; BLS, below land surface; ft BLS, feet below land surface; --, no data]

\begin{tabular}{|c|c|c|c|c|c|}
\hline $\begin{array}{c}\text { Sample } \\
\text { description }\end{array}$ & $\begin{array}{c}\text { Se } \\
(\mu g / g)\end{array}$ & $\underset{(\mu g / g)}{U}$ & $\begin{array}{c}V \\
(\mu g / g)\end{array}$ & $\underset{\text { (percent) }}{\mathrm{Fe}}$ & $\begin{array}{c}\text { Organic } \\
\text { carbon } \\
\text { (percent) }\end{array}$ \\
\hline \multicolumn{6}{|c|}{ MANCOS SHALE BEDROCK } \\
\hline Mancos Shale, bedrock sample from core, $2,317 \mathrm{ft}$ BLS & 0.8 & 7.4 & 50 & 1.7 & 1.36 \\
\hline Ash layer, bedrock sample from core, $2,271 \mathrm{ft}$ BLS & $<.1$ & 13.9 & 4 & 1.8 & .12 \\
\hline Pyrite and shale, bedrock sample adjacent to ash layer, $2,297 \mathrm{ft}$ BLS & 1.6 & 11.2 & 13 & 2 & 1.55 \\
\hline Pyrite euhedron, isolated from bedrock core, adjacent to ash layer & 19 & -- & -. & -- & -- \\
\hline \multicolumn{6}{|c|}{ MANCOS SHALE RESIDUUM } \\
\hline Weathered ash, outcrop of ash layer, upper Mancos Shale & 3.9 & 8.38 & 40 & 2.3 & .39 \\
\hline Shale residuum, sediment-core sample from well SL2, $2 \mathrm{ft}$ BLS & 1.1 & 4.77 & 130 & 2.1 & .44 \\
\hline Shale residuum, sediment-core sample from well SL2, $7 \mathrm{ft}$ BLS & .8 & 4.63 & 160 & 2.4 & .56 \\
\hline Shale residuum, sediment-core sample from well SL2, $9 \mathrm{ft}$ BLS & .8 & 4.16 & 160 & 2.5 & .51 \\
\hline Gypsum, from bedding-plane parting, well SL1 & $<1$ & - & -- & -- & - \\
\hline \multicolumn{6}{|c|}{ ALLUVIUM OVERLYING MANCOS SHALE } \\
\hline Alluvium, sediment-core sample from well RWG1, $6 \mathrm{ft}$ BLS & 3.6 & 4.55 & 150 & 2.2 & .38 \\
\hline Alluvium, sediment-core sample from well RWG1, $8 \mathrm{ft} \mathrm{BLS}$ & 2.8 & 4.48 & 140 & 2.1 & .32 \\
\hline Alluvium, sediment-core sample from well RWG1, $27 \mathrm{ft}$ BLS & 1.7 & 3.79 & 100 & 2 & .32 \\
\hline
\end{tabular}

Selenium concentrations in alluvium samples were more than 4 times greater than in shale bedrock (table 8), indicating a concentrating effect from adsorption of selenium onto clay minerals and possibly reduction of selenium to a less mobile form. The concentrations of selenium, uranium, and vanadium indicate an upward gradient, possibly indicating transport toward the ground surface by capillary action and a concentrating effect from evaporation.

\section{Occurrence of Selenium in Ground Water}

\section{Distribution}

The conceptual model for the occurrence, mobilization, and redistribution of solid-phase and dissolved selenium in the Mancos Shale, shale residuum, and alluvium includes: (1) Oxidation of pyrite containing trace concentrations of selenium; (2) mobilization of selenium by ground water under oxidizing conditions; (3) immobilization and redistribution of selenium by biogeochemical reduction, coprecipitation, or adsorption, or all three; or (4) transport of oxidized selenium to streams and drains. Aqueous selenium complexes could migrate from oxidized zones into zones of geochemically reducing environments where dissolved selenium would be converted to less mobile species (or redistributed) by biogeochemical reduction, adsorption, or coprecipitation. Adsorbed selenium could be mobilized by desorption or oxidation, or both. A conceptualized model of the occurrence of selenium in Mancos Shale, shale residuum, and alluvium in the irrigated areas of the Uncompahgre Project area and the Grand Valley is shown in figure 16.

In the Uncompahgre Project area and in the Grand Valley, distribution and concentrations of dissolved selenium differ according to geochemical environment and hydrogeologic setting (table 9). In general, the highest concentrations of dissolved selenium -as high as $1,300 \mu \mathrm{g} / \mathrm{L}$-were in water from wells completed in alluvium overlying the Mancos Shale and where nitrate concentrations were high. The lowest concentrations of dissolved selenium were in water from wells completed in terrace deposits on the western side 


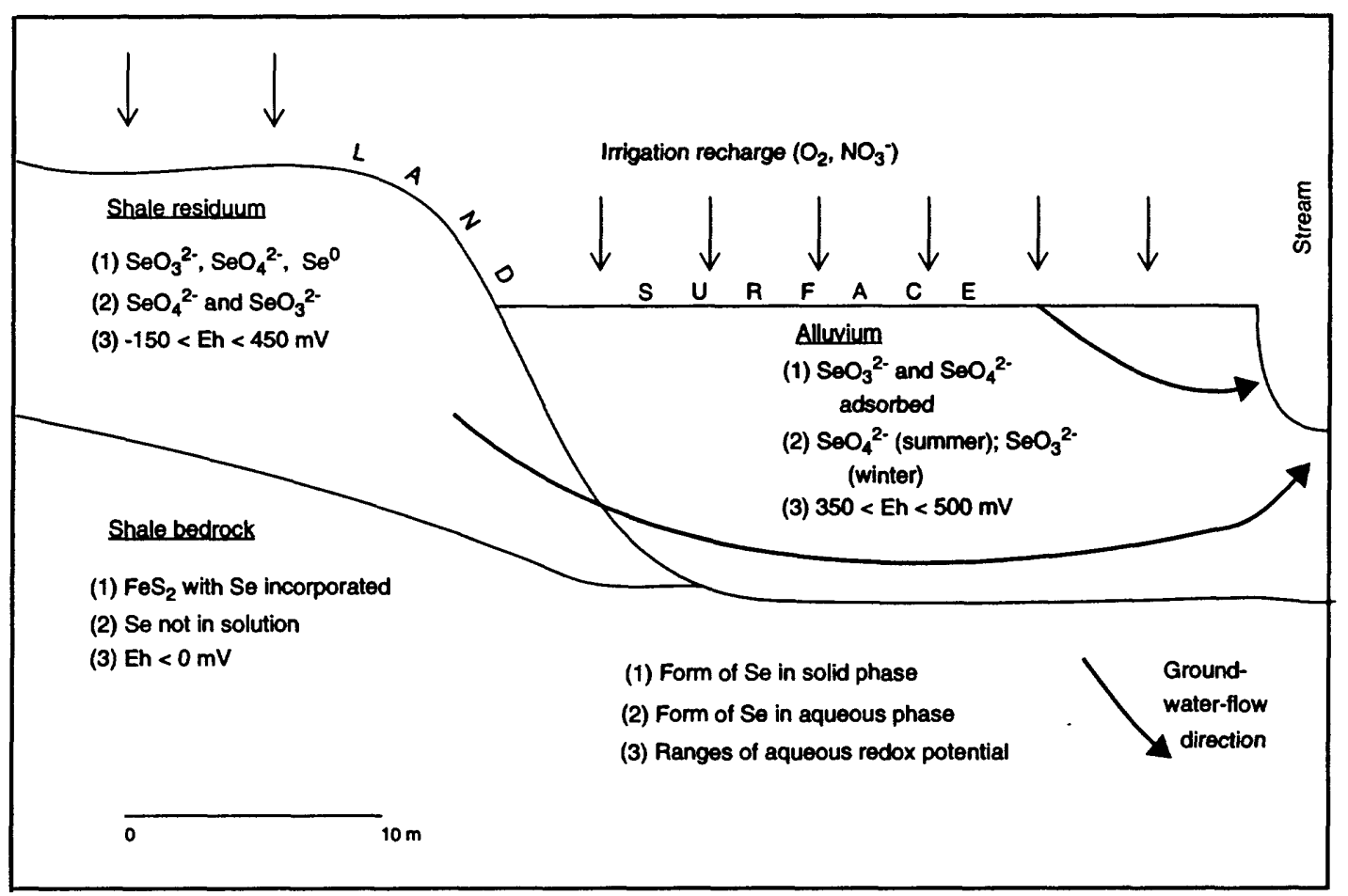

Figure 16. Conceptual model of the occurrence of selenium (Se) in Mancos Shale, shale residuum, alluvium, and ground water in the Uncompahgre Project area and in the Grand Valley.

of the Uncompahgre Valley (the terrace deposits are of glacial origin and do not contain detritus from weathered Mancos Shale), in water from wells completed in Mancos Shale residuum, and where iron concentrations were high.

The distribution of selenium and other elements (such as nitrogen, iron, and manganese) are affected by the oxidation potential of the geochemical environment. Where table 9 lists the general classifications of the geochemical environments pertinent to selenium occurrence and distribution, table 10 lists ground-water data for common indicators of the oxidation-reduction characteristics of the subsurface geochemical environment. Where geochemical conditions are anoxic, dissolved iron, manganese, and ammonia concentrations are relatively high, and dissolved oxygen, nitrate, and selenium concentrations are low (table 10). In contrast, where geochemical conditions are oxic, dissolved iron, manganese, and ammonia concentrations are relatively low, and dissolved oxygen, nitrate, and selenium concentrations are high (table 10). Many factors can affect these conditions, such as rainfall, snowmelt, irrigation, and bacteria that can mediate chemical reactions.
Table 9. Geochemical environments of the ground-waterflow systems, hydrogeologic settings, and ranges of dissolved-selenium concentrations in Mancos Shale residuum and alluvium in the irrigated Uncompahgre Project area and in the Grand Valley

[Oxic/anoxic environment, ground water with dissolved-oxygen concentrations ranging from 0.5 to $2 \mathrm{mg} / \mathrm{L}$ (milligrams per liter); anoxic, $\leq 0.5 \mathrm{mg} / \mathrm{L}$; $\mu \mathrm{g} / \mathrm{L}$, micrograms per liter; $\mathrm{Mn}$, manganese; $\mathrm{Fe}$, iron; $\mathrm{NO}_{3}{ }^{-}$, nitrate]

\begin{tabular}{|c|c|c|}
\hline $\begin{array}{l}\text { Geochemical } \\
\text { environment }\end{array}$ & $\begin{array}{l}\text { Hydrogeologic } \\
\text { setting }\end{array}$ & $\begin{array}{l}\text { Ranges of dissolved- } \\
\text { selenium } \\
\text { concentrations in } \\
\text { ground water }\end{array}$ \\
\hline Oxic/anoxic & $\begin{array}{l}\text { Alluvium on } \\
\text { Mancos } \\
\text { Shale }\end{array}$ & Moderate -43 to $80 \mu \mathrm{g} / \mathrm{L}$ \\
\hline $\begin{array}{l}\text { Oxic/anoxic } \\
\text { Mn rich }\end{array}$ & $\begin{array}{l}\text { Alluvium, } \\
\text { shale } \\
\text { residuum }\end{array}$ & Low to high $\longrightarrow 1$ to $170 \mu \mathrm{g} / \mathrm{L}$ \\
\hline $\begin{array}{l}\text { Oxic/anoxic } \\
\text { Fe rich }\end{array}$ & $\begin{array}{l}\text { Mancos Shale } \\
\text { residuum }\end{array}$ & Low $\longrightarrow 1$ to $35 \mu \mathrm{g} / \mathrm{L}$ \\
\hline $\begin{array}{l}\text { Anoxic } \\
\text { Mn rich }\end{array}$ & $\begin{array}{l}\text { Mancos Shale } \\
\text { residuum }\end{array}$ & Low to moderate $-<1$ to $65 \mu \mathrm{g} / \mathrm{L}$ \\
\hline $\begin{array}{l}\text { Anoxic } \\
\text { Fe rich }\end{array}$ & $\begin{array}{l}\text { Mancos Shale } \\
\text { residuum }\end{array}$ & Very low $\longrightarrow<1 \mu \mathrm{g} / \mathrm{L}$ \\
\hline $\begin{array}{l}\text { Anoxic } \\
\mathrm{NO}_{3}^{-}\end{array}$ & $\begin{array}{l}\text { Alluvium on } \\
\text { Mancos } \\
\text { Shale }\end{array}$ & $\begin{array}{l}\text { Moderate to high }-25 \text { to } \\
1,300 \mu \mathrm{g} / \mathrm{L}\end{array}$ \\
\hline
\end{tabular}




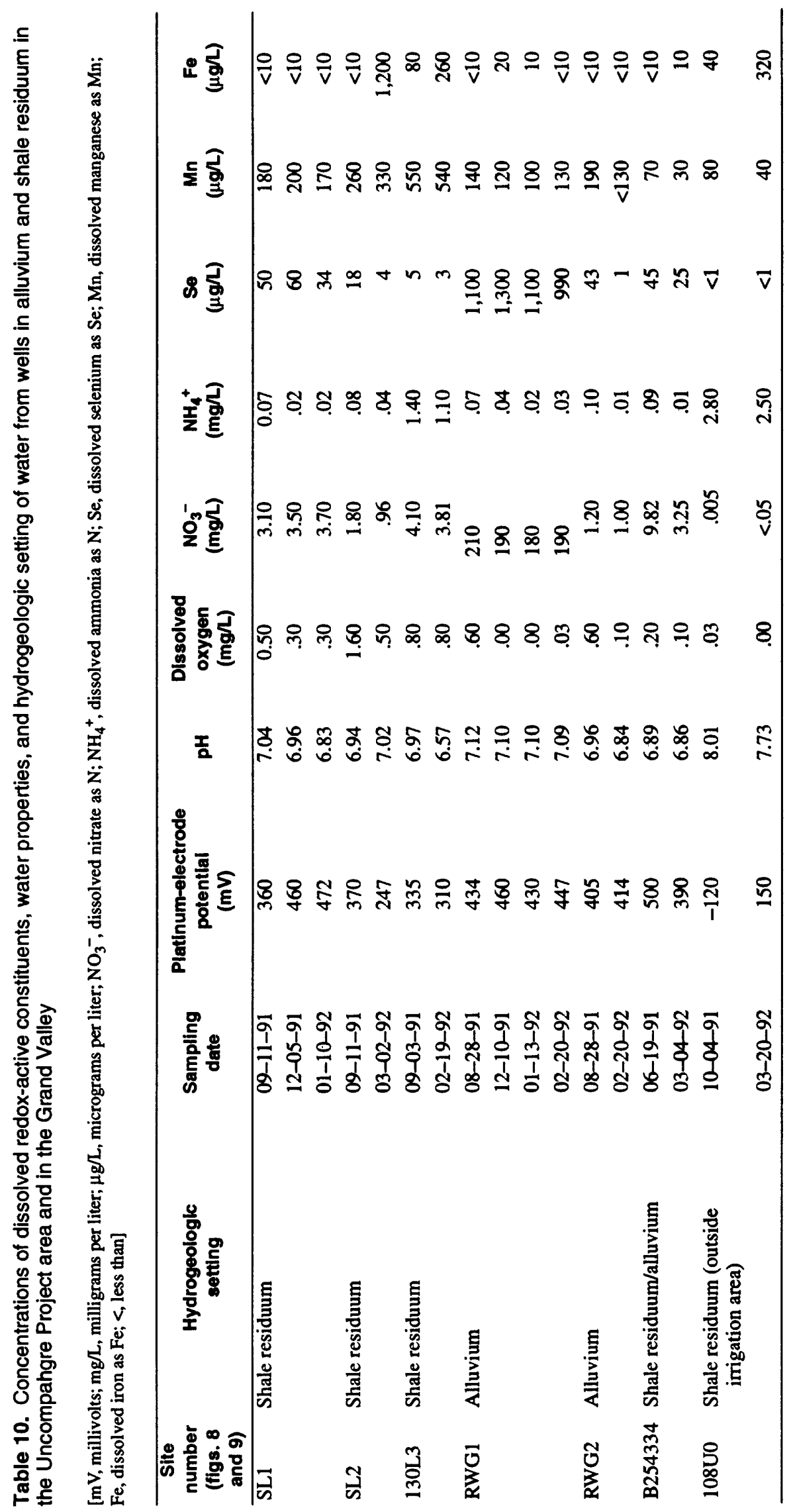


The oxidation-reduction potential (or redox potential, expressed in millivolts) can be approximated in the field by a platinum electrode. Platinumelectrode potential is an important indicator of geochemical conditions-low platinum-electrode potential (generally less than about $400 \mathrm{mV}$ ) indicates a geochemically reducing environment and high platinum-electrode potential (generally greater than about $400 \mathrm{mV}$ ) indicates an oxidizing geochemical environment. In the Uncompahgre Project area and in the Grand Valley, dissolved selenium occurs in lower concentrations where the platinum-electrode potential is lower and the hydrogeologic system is more reducing, such as in the Mancos Shale residuum (fig. 17). These conditions indicate that selenium is more mobile in oxygenated environments (onsite platinum-electrode potential greater than about $300 \mathrm{mV}$ ), and selenium is immobilized in reducing environments (onsite platinum-electrode potential less than about $300 \mathrm{mV}$ ). In the reduction sequence of aqueous complexes called the redox ladder (Berner, 1981), reduction of selenate follows oxygen and nitrate, which then are followed by the reduction of manganese, iron, and sulfate.

\section{Seasonal Effects}

Dissolved selenium concentrations in ground water of the study area generally tend to increase during summer (irrigation season) when irrigation water is applied. Selenium concentrations generally decrease in winter (nonirrigation season) when irrigation water is turned off and reducing geochemical conditions remove selenium from the aqueous phase (fig. 18). Of the 16 wells sampled seasonally, selenium concentrations were lower in winter than in summer in water from 9 of 16 wells. Primarily, water from wells in shale residuum showed these seasonal effects; water from wells in alluvium might not indicate such seasonal effects because oxidizing conditions could be maintained in the alluvial aquifer.

During the nonirrigation season, dissolved selenium can be reduced to less mobile species where geochemical conditions are favorable for selenium reduction. Selenium-speciation data for dissolved selenium in selected groundwater samples collected during the nonirrigation

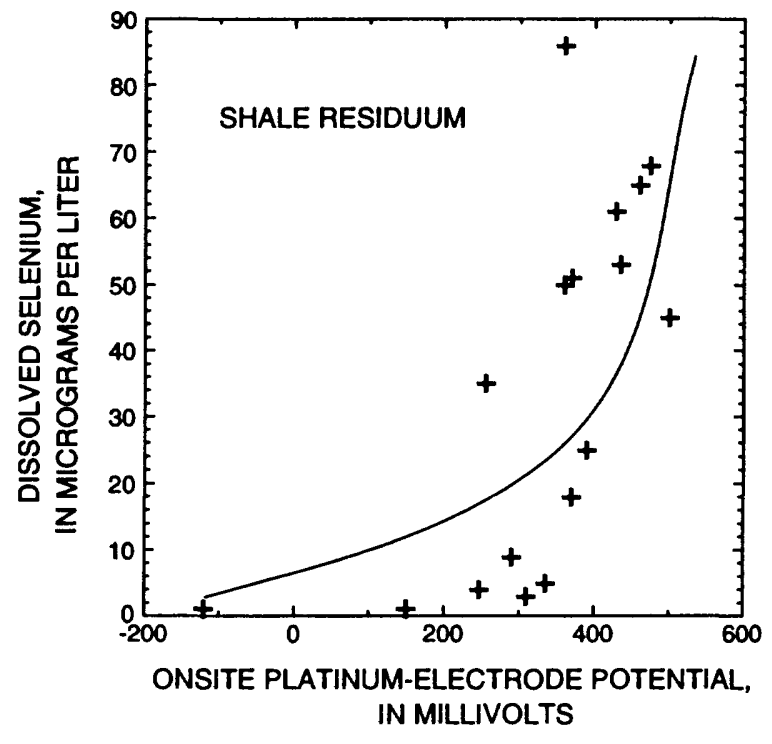

Figure 17. Platinum-electrode potential and concentrations of dissolved selenium in water from wells in Mancos Shale residuum. (Hand-fitted correlation shown.)

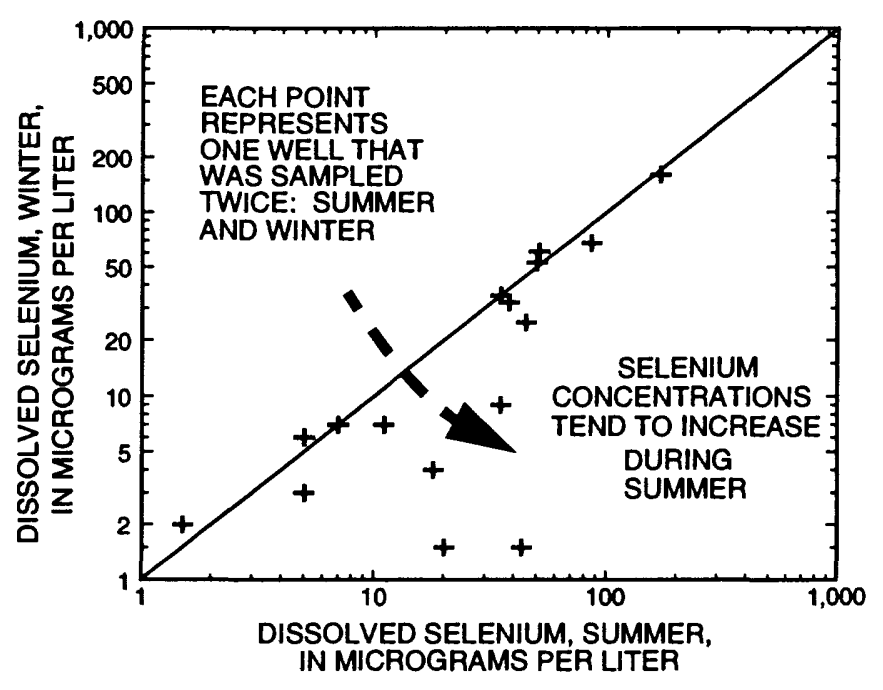

Figure 18. Dissolved selenium in water from wells in shale residuum and alluvium during the irrigation season (summer) and nonirrigation season (winter).

season are listed in table 11. The percent of $\mathrm{Se}^{\mathrm{IV}} \mathrm{O}_{3}{ }^{2-}$ (selenite) in two samples was 28.3 and 50.5 percent of the total dissolved-selenium concentration in the samples, indicating that reducing conditions could have been converting $\mathrm{Se}^{\mathrm{VI}} \mathrm{O}_{4}{ }^{2-}$ (selenate) to $\mathrm{Se}^{\mathrm{IV}} \mathrm{O}_{3}{ }^{2-}$ and tending to remove dissolved selenium from the aqueous phase. 
Table 11. Speciation of dissolved selenium in selected ground-water samples from the Uncompahgre Project area and from the Grand Valley (analyses courtesy of Roger Fujii and A.T. Chalmers, U.S. Geological Survey, written commun., 1992)

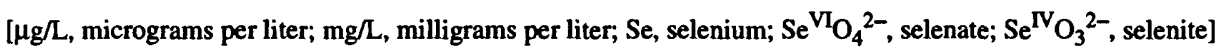

\begin{tabular}{|c|c|c|c|c|c|c|}
\hline $\begin{array}{c}\text { Site } \\
\text { number } \\
\text { (figs. 8 } \\
\text { and 9) }\end{array}$ & $\begin{array}{c}\text { Hydrogeologlc } \\
\text { setting }\end{array}$ & $\begin{array}{l}\text { Sampling } \\
\text { date }\end{array}$ & $\begin{array}{c}\text { Dlssolved } \\
\text { Se } \\
(\mu g / L)\end{array}$ & $\begin{array}{c}\mathrm{Se}^{\mathrm{V}} \mathrm{O}_{4}{ }^{2-} \\
(\mu \mathrm{g} / \mathrm{L})\end{array}$ & $\begin{array}{c}\mathrm{Se}^{\mathrm{IV}} \mathrm{O}_{3}{ }^{2-} \\
(\mu \mathrm{g} /)\end{array}$ & $\begin{array}{l}\text { Percent } \\
\mathrm{Se}^{\mathrm{N} \mathrm{O}_{3}{ }^{2-}}\end{array}$ \\
\hline$\overline{R W G 1}$ & $\begin{array}{l}\text { Alluvium in Mancos Shale setting, Grand Valley, } \\
\mathrm{NO}_{3}{ }^{-}=200 \mathrm{mg} / \mathrm{L}\end{array}$ & $03-19-92$ & $1,056.2$ & $1,055.4$ & 0.8 & 0.08 \\
\hline RWG2 & Alluvium overlying Mancos Shale, Grand Valley & 03-19-92 & 1.9 & 1.4 & .5 & 28.3 \\
\hline SL1 & Mancos Shale residuum, Uncompahgre Valley & $03-23-92$ & 50.1 & 49 & 1.1 & 2.3 \\
\hline Schmalz & Terrace deposits, Uncompahgre Valley & $03-23-92$ & 6.9 & 3.4 & 3.5 & 50.5 \\
\hline
\end{tabular}

\section{Mobilization and Transport of Selenium}

Selenium in the Uncompahgre Project area and in the Grand Valley can be mobilized by oxidation of reduced selenium species, by desorption of selenate and selenite salts from aquifer sediments, and by dissolution of selenium. Dissolved selenium can be immobilized by natural reducing conditions. During summer, selenium could be mobilized and transported more readily by irrigation water; during winter, the water table lowers and geochemical conditions become more reducing by the action of naturally occurring microorganisms, which tend to remove selenium from solution in the ground-water system. Selenium mobilization in the study area is affected by salinity, desorption or ion exchange, and oxidationreduction processes, depending on the hydrogeologic system that controls the geochemical environment, similar to hypotheses presented by See and others (1992).

Selenium can be mobilized by oxidation of reduced selenium species. Oxidation of selenium occurs by the chemical actions of dissolvedoxygen and nitrate in ground water. Nitrate can act as an oxidant to mobilize selenium (Wright, 1994; Wright and McMahon, 1994; Wright, 1995), and nitrate can inhibit selenium reduction (Oremland and others, 1989). More discussion on this topic is provided in the "Selenium Oxidation." section.

Dissolved selenium can be mobilized by desorption of selenate and selenite salts that are adsorbed to aquifer sediments. Sequential extractions were performed on aquifer-sediment samples to estimate the water-extractable selenium (selenate salts) and the surface-adsorbed selenium (selenite salts) (Roger Fujii and A.T. Chalmers, U.S. Geological Survey, written commun., 1992). An estimate of the water-extractable selenium was obtained by using a $0.25 \mathrm{M} \mathrm{KCl}$ (potassium chloride) extraction solution that indicates the potentially water-soluble selenium in the sediment sample (Fujii and others, 1988). An estimate of the surface-adsorbed selenium was obtained by using a $0.1 \mathrm{M} \mathrm{K} \mathrm{KPO}_{4}$ (potassium phosphate) extraction solution adjusted to $\mathrm{pH} 8$ with KOH (potassium hydroxide) (Fujii and others, 1988). Selenium-speciation analyses were performed on the extractions (Makita and Fujii, 1992). Speciation of sequential extractions from two alluvial-aquifer-sediment samples indicates that the extractions estimating the water-soluble phases consisted mostly of selenate $\left(\mathrm{Se}^{\mathrm{VI}} \mathrm{O}_{4}{ }^{2-}\right.$ ), and the extractions estimating the surface-adsorbed phases consisted mostly of selenite $\left(\mathrm{Se}^{\mathrm{IV}} \mathrm{O}_{3}{ }^{2-}\right)$ (table 12). Selenate forms a weakly bonded, outer-sphere complex; selenite adsorbs much more strongly than selenate and forms a stronger bonded, inner-sphere complex (Electric Power Research Institute, 1980; Balistrieri and Chao, 1987; Hayes and others, 1987).

Kaolinite and smectite (dominant clay minerals in Mancos Shale residuum, weathered ash layers, and alluvium) are reported to readily adsorb selenium and affect selenium concentrations in soil solutions (Electric Power Research Institute, 1980; Bar-Yosef and Meek, 1987); and dissolved selenium can coprecipitate with ferric hydroxide (Electric Power 
Table 12. Speciation of extractable selenium in alluvial-aquifer-sediment samples from the Grand Valley (analyses courtesy of Roger Fujii and A.T. Chalmers, U.S. Geological Survey, written commun., 1992)

[Total $\mathrm{KCl}$ extractable Se is the potentially water-soluble selenium in sediment sample; total $\mathrm{K}_{2} \mathrm{HPO}_{4}$ extractable Se is an estimate of the surfaceadsorbed selenium; $\mu \mathrm{g} / \mathrm{g}$, micrograms per gram; $\mathrm{ft} \mathrm{BLS}$, feet below land surface]

\begin{tabular}{|c|c|c|c|c|c|c|}
\hline $\begin{array}{c}\text { Site } \\
\text { number } \\
\text { (fig. 9) }\end{array}$ & $\begin{array}{l}\text { Hydrogeologic } \\
\text { setting }\end{array}$ & $\begin{array}{l}\text { Sampling } \\
\text { date }\end{array}$ & $\begin{array}{c}\text { Total KCl } \\
\text { extractable Se } \\
(\mu g / g)\end{array}$ & 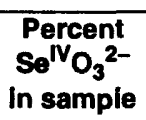 & $\begin{array}{c}\text { Total } \mathrm{K}_{2} \mathrm{HPO}_{4} \\
\text { extractable Se } \\
(\mu g / g)\end{array}$ & 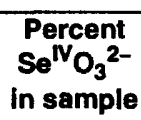 \\
\hline RWG1 & $\begin{array}{l}\text { Alluvium on Mancos Shale, } \\
\text { Grand Valley, } 13 \mathrm{ft} \text { BLS }\end{array}$ & $08-25-91$ & 0.16 & 1.5 & 0.12 & 96 \\
\hline RWG1 & $\begin{array}{l}\text { Alluvium on Mancos Shale, } \\
\text { Grand Valley, } 24 \mathrm{ft} \text { BLS }\end{array}$ & $08-25-91$ & .020 & 4 & .084 & 76 \\
\hline
\end{tabular}

Research Institute, 1980), adsorb to goethite (Hayes and others, 1987), or precipitate as iron selenite after fluid migration to reducing zones (Elrashidi and others, 1987). These adsorption processes are completely reversible (Balistrieri and Chao, 1987), indicating that desorption could mobilize selenium. In addition, high salinity concentrations could change the electrical nature of the outer layer of clay minerals (the salinity effect), whereby the hydroxyl ion could displace selenium oxyanions from outer-layer adsorption sites (Balistrieri and Chao, 1987), thereby mobilizing selenium.

Selenium can be mobilized by dissolution. Dissolved selenium in ground water of the Uncompahgre Project area and of the Grand Valley is positively correlated with dissolved-solids concentrations in water from wells completed in alluvium, but dissolved selenium is negatively correlated with dissolved-solids concentrations in water from wells completed in shale residuum (fig. 19). The negative correlation for shale residuum could be related to dissolved-solids concentrations that increase during the nonirrigation season (a concentrating effect), and biogeochemical reduction of dissolved selenium occurs concurrently with the concentrating effect (Wright and Butler, 1993). Consequently, dissolved selenium is more mobile in alluvium than in shale residuum, which also is reflected by selenium concentrations in shale residuum.

Selenium can be immobilized by natural reducing conditions. Framboidal pyrite (fig. 20) was collected on filter paper from filtered ground water from a well (100 ft deep in Mancos Shale residuum) located outside the irrigated area in the
Grand Valley. The geochemical conditions were sufficiently reducing $(\mathrm{Eh}=-120 \mathrm{mV})$ to precipitate pyrite from available dissolved iron and abundant sulfate in the ground water; likewise, selenium would be reduced and immobilized and possibly incorporated into the crystalline structure of the pyrite. Similar reducing conditions might occur during winter within the irrigated areas that could immobilize dissolved selenium. If not for irrigation, geochemical conditions within the study area could be reducing; however, irrigation infiltration provides oxidizing conditions suitable for mobilization and transport of selenium.

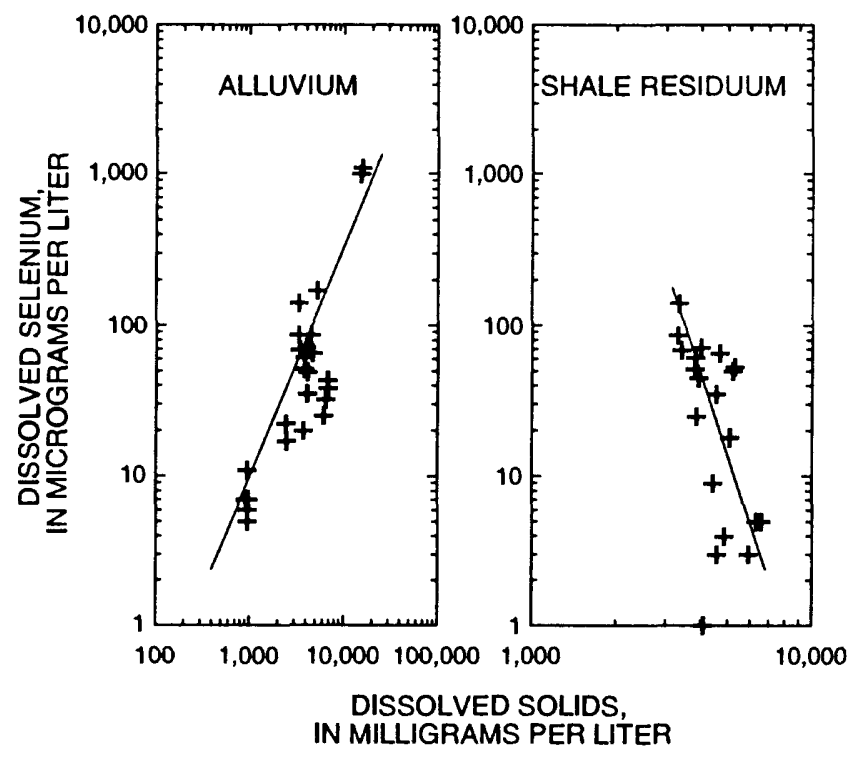

Figure 19. Correlation of dissolved solids and dissolved selenium in water from wells in alluvium $(r=+0.85)$ and shale residuum ( $r=-0.55$ ) (from Wright and Butler, 1993). 


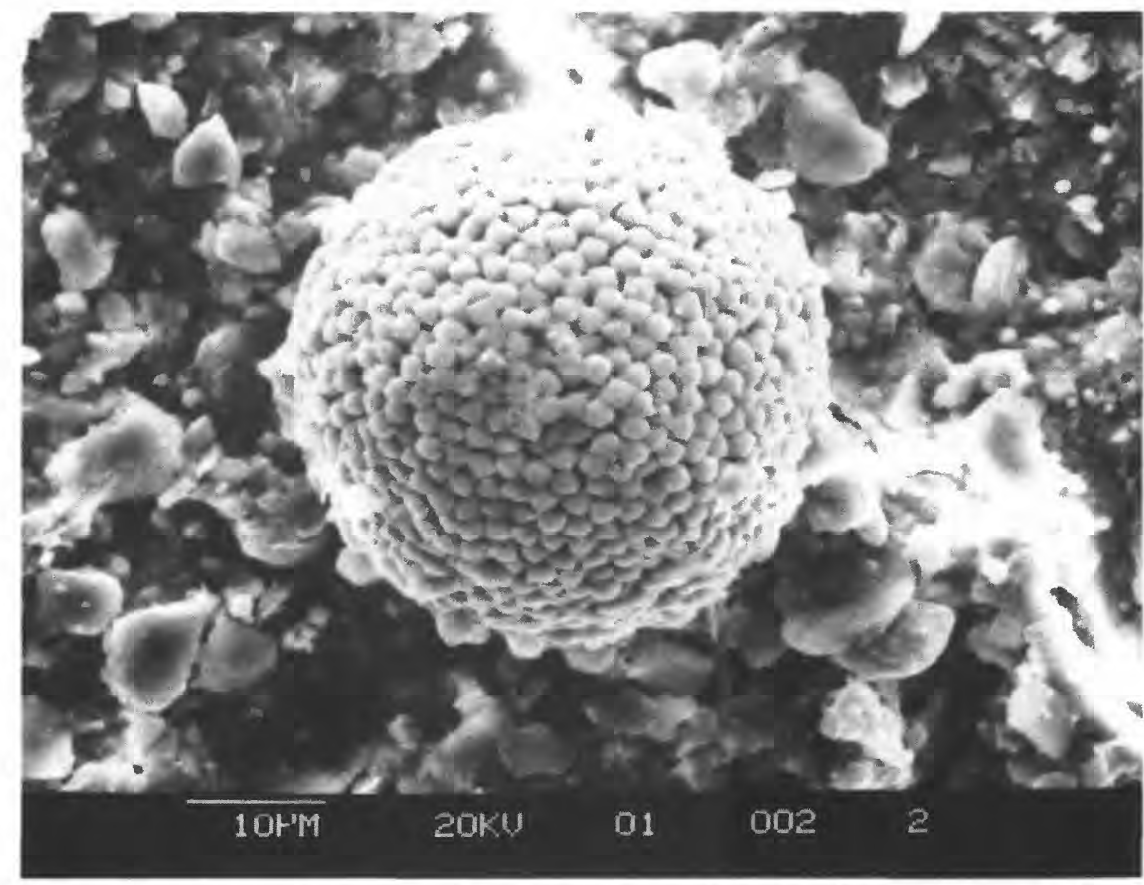

Figure 20. Scanning-electron photomicrograph of framboidal pyrite collected on 0.45 -micrometer water-filter paper from a well located outside the irrigated Grand Valley area, October 1991. Platinum-electrode potential was -120 millivolts, and $\delta^{34} \mathrm{~S}$ was +6.4 per mil. Scale bar in lower left indicates 10 micrometers.

\section{Selenium Oxidation}

Reduced selenium complexes occurring in the Mancos Shale residuum and alluvium might be mobilized by oxidants, such as dissolved oxygen and nitrate, in ground water. In ground-water systems that can become depleted of oxygen, such as organic-rich systems in the Mancos Shale and Mancos Shale residuum, $\mathrm{NO}_{3}{ }^{-}$might act as an oxidant for mobilization of selenium. $\mathrm{NO}_{3}{ }^{-}$ concentrations in ground-water samples range from $<0.05$ to $210 \mathrm{mg} / \mathrm{L}$ as $\mathrm{N}$ in the study area (table 5). Thermodynamic relations for selenium oxidation indicate that elemental selenium could be oxidized to selenite $\left(\mathrm{Se}^{\mathrm{IV}} \mathrm{O}_{3}{ }^{2-}\right.$ ) and selenate $\left(\mathrm{Se}^{\mathrm{VI}^{\mathrm{I}}} \mathrm{O}_{4}{ }^{2-}\right.$ ) by nitrate and nitrite, and theoretical energies for some of the reactions almost equal the energy available for oxidation of selenium by oxygen (table 13). Several investigators have indicated that $\mathrm{NO}_{3}{ }^{-}$ inhibits the reduction of $\mathrm{Se}^{\mathrm{VI}} \mathrm{O}_{4}{ }^{2-}$. Oremland and others (1989), in anaerobic culture experiments, indicated that the inhibition of $\mathrm{Se}^{\mathrm{VI}} \mathrm{O}_{4}{ }^{2-}$ reduction by $\mathrm{NO}_{3}{ }^{-}$was caused by either action of $\mathrm{NO}_{3}{ }^{-}$as a competitive electron acceptor or that $\mathrm{NO}_{3}{ }^{-}$is able to reoxidize reduced, precipitated selenium from sediment. Weres and others (1989) postulated that $\mathrm{NO}_{3}{ }^{-}$poised the $\mathrm{pE}$ value too high for significant $\mathrm{Se}^{\mathrm{V}} \mathrm{O}_{4}{ }^{2-}$ reduction. Because selenium reduction was the focus of these investigations, the oxidation of selenium by $\mathrm{NO}_{3}{ }^{-}$was not elaborated upon further. Korom (1992), in a review of denitrification processes, presented a reaction for oxidation of $\mathrm{FeS}_{2}$ by $\mathrm{NO}_{3}{ }^{-}$, which yields $\mathrm{N}_{2}$ and $\mathrm{SO}_{4}{ }^{2-}$ and also indicates that the process might be mediated by bacteria.

Laboratory-batch experiments were performed for this study to test the hypothesis that selenium could be oxidized by nitrate. Samples of Mancos Shale residuum were placed in different concentrations of nitrate. All preparations were made in an argon-filled glovebox to prevent the introduction of atmospheric oxygen into the samples. Preliminary results indicate that selenium can be oxidized by nitrate under laboratory conditions of elevated temperature $\left(25^{\circ} \mathrm{C}\right)$ and nitrate concentrations of 5,50,100, and 1,000 mg/L (Wright and McMahon, 1994; Wright, 1995); however, extrapolation of these rates to field 
conditions have not been done. The oxidation rate depends on the nitrate concentration. Additional research is needed to document if these reactions actually are occurring and if the reaction rate is high enough to be of significance in ground water associated with irrigation in the study area.

Table 13. Energies of reaction for oxidation of selenium by oxygen and nitrate

$\left[0, I V\right.$, and VI indicate the oxidation state of the selenium; $\Delta G_{R}{ }^{0}$, Gibbs free energy term; $\mathrm{kJ} / \mathrm{mol}$, kiloJoules per mole; thermodynamic data are from Garrels and Christ (1965)]

\begin{tabular}{|c|c|c|c|}
\hline $\begin{array}{l}\text { Selenium } \\
\text { reactant }\end{array}$ & Oxidant & $\begin{array}{l}\text { Selenium } \\
\text { product }\end{array}$ & $\begin{array}{c}\text { Theoretical } \\
\text { energy } \\
\text { for reaction } \\
\left(\Delta G_{R}{ }^{0}, \mathrm{~kJ} / \mathrm{mol}\right)\end{array}$ \\
\hline \multirow[t]{2}{*}{$\mathrm{Se}^{0}$} & $\mathrm{O}_{2}$ & $\mathrm{Se}^{\mathrm{IV}} \mathrm{O}_{3}{ }^{2-}$ & -724 \\
\hline & $\mathrm{NO}_{3}{ }^{-}$ & $\mathrm{Se}^{\mathrm{IV}} \mathrm{O}_{3}{ }^{2-}$ & -525 \\
\hline \multirow[t]{3}{*}{$\mathrm{HSe}^{\mathrm{IV}} \mathrm{O}_{3}{ }^{-}$} & $\mathrm{O}_{2}$ & $\mathrm{Se}^{\mathrm{VI}} \mathrm{O}_{4}{ }^{2-}$ & -264 \\
\hline & $\mathrm{NO}_{3}^{-}$ & $\mathrm{Se}^{\mathrm{VI}} \mathrm{O}_{4}{ }^{2-}$ & +46 \\
\hline & $\mathrm{NO}_{2}^{-}$ & $\mathrm{Se}^{\mathrm{VI}} \mathrm{O}_{4}{ }^{2-}$ & -464 \\
\hline \multirow[t]{2}{*}{$\mathrm{Se}^{\mathrm{IV}} \mathrm{O}_{3}{ }^{2-}$} & $\mathrm{O}_{2}$ & $\mathrm{Se}^{\mathrm{VI}} \mathrm{O}_{4}{ }^{2-}$ & -270 \\
\hline & $\mathrm{NO}_{3}^{-}$ & $\mathrm{Se}^{\mathrm{VI}} \mathrm{O}_{4}{ }^{2-}$ & +8.7 \\
\hline \multirow[t]{3}{*}{$\mathrm{FeHSe}^{\mathrm{IV}} \mathrm{O}_{3}{ }^{2+}$} & $\mathrm{O}_{2}$ & $\mathrm{Se}^{\mathrm{VI}} \mathrm{O}_{4}{ }^{2-}$ & -300 \\
\hline & $\mathrm{NO}_{3}^{-}$ & $\mathrm{HSe}^{\mathrm{IV}} \mathrm{O}_{3}^{-}$ & -27 \\
\hline & $\mathrm{NO}_{3}^{-}$ & $\mathrm{Se}^{\mathrm{VI}} \mathrm{O}_{4}{ }^{2-}$ & +94 \\
\hline
\end{tabular}

\section{Indicators of Microbial Activity}

Selenium is sensitive to oxidation-reduction processes in a ground-water system. Many of these processes are mediated by microbes (bacteria), and a carbon source (such as kerogen in Mancos Shale and Mancos Shale residuum) is necessary for bacterial metabolism. This microbial activity leaves imprints in geochemical characteristics of the water. Sulfur isotopes of dissolved sulfate $\left(\delta^{34} \mathrm{SO}_{4}\right)$ can be such an indicator of microbial activity.

The sulfur-34/sulfur-32 isotope $\left(\delta^{34} S\right)$ values of pyrite in the Mancos Shale range from -34 to +22 per mil CDT (Canyon Diablo troilite) (G. Breit, U.S. Geological Survey, oral commun., 1992). The $\delta^{34} \mathrm{SO}_{4}$ values for ground water in the study area range from -26 to +6.4 per mil CDT; however, in the irrigated areas, $\delta^{34} \mathrm{SO}_{4}$ ranges from -26.4 to -8.9 per mil CDT (table 14). When $\delta^{34} \mathrm{SO}_{4}$ in summer (irrigation-season samples) to winter (nonirrigation-season samples) are compared, some of the wells show a depletion in $\delta^{34} \mathrm{SO}_{4}$, and some of the wells show an enrichment in $\delta^{34} \mathrm{SO}_{4}$. Wells in Mancos Shale residuum all showed a depletion in $\delta^{34} \mathrm{SO}_{4}$ values.

The effects of irrigation water and the presence of anthropogenic nitrate could keep ground water in Mancos Shale residuum in a transitional redox state. The winter dissolved- $\mathrm{SO}_{4}{ }^{2-}$ pool could partly be reduced to intermediate oxidation states (such as sulfite or thiosulfate) with no isotope effect (Kemp and Thode, 1968) and then reoxidized by oxidizing bacteria that could impart a fractionation showing a depletion in $\delta^{34} \mathrm{SO}_{4}$ (Fry and others, 1988). These dynamic changes in $\delta^{34} \mathrm{SO}_{4}$ indicate an active microbial system that could affect selenium mobility.

\section{Relation of Selenium to Other Constituents}

Dissolved selenium in ground water in the Uncompahgre Project area and in the Grand Valley primarily is determined by the oxidizing conditions present in the ground water. Oxidizing conditions suitable for selenium mobilization are indicated by the relation of dissolved selenium to other dissolved constituents (fig. 21). Presser and others (1990) reported that selenium precipitates with magnesium-based evaporite complexes (such as thenardite) and does not precipitate with calcium-based evaporite complexes (such as gypsum), indicating that selenium prefers to complex with magnesium-based compounds in solution, which might be related to the solubilities of the different calcium- and magnesium-based evaporites and the saturation states of the evaporite complexes that weather from marine shales. A positive correlation between dissolved magnesium and dissolved selenium is shown in figure 21 ; however, this trend does not conclusively prove any geochemical significance regarding selenium mobilization in the presence of dissolved magnesium. 
Table 14. Sulfur-isotope data for water from selected wells in shale residuum and alluvium

\begin{tabular}{|c|c|c|c|}
\hline $\begin{array}{c}\text { Site } \\
\text { number } \\
\text { (figs. } 8 \\
\text { and 9) }\end{array}$ & $\begin{array}{l}\text { Sampling } \\
\text { date }\end{array}$ & $\begin{array}{c}\delta^{34} \mathrm{SO}_{4} \\
\text { (per mil) }\end{array}$ & Comments \\
\hline \multicolumn{4}{|c|}{ MANCOS SHALE RESIDUUM } \\
\hline $130 \mathrm{L3}$ & September 1991 & -14.8 & - \\
\hline $130 \mathrm{~L} 3$ & February 1992 & -16.0 & Depleted 1.2 per mil from September 1991 \\
\hline $125 \mathrm{Q} 5$ & September 1991 & -8.9 & - \\
\hline 125Q5 & February 1992 & -19.7 & Depleted 10.8 per mil from September 1991 \\
\hline SL1 & September 1991 & -20.9 & -- \\
\hline SL1 & February 1992 & -22.0 & Depleted 1.1 per mil from September 1991 \\
\hline B254334 & June 1991 & -26.4 & -- \\
\hline $108 \mathrm{UO}^{1}$ & October 1991 & +6.4 & Framboidal pyrite on water-filter paper \\
\hline \multicolumn{4}{|c|}{ ALLUVIUM OVERLYING MANCOS SHALE } \\
\hline RWG1 & August 1991 & -21.0 & -- \\
\hline RWG1 & February 1992 & -20.8 & Enriched 0.2 per mil from August 1991 \\
\hline RWG2 & August 1991 & -20.3 & -- \\
\hline RWG2 & February 1992 & -20.6 & Depleted 0.3 per mil from August 1991 \\
\hline RWG3 & August 1991 & -19.6 & -- \\
\hline RWG3 & February 1992 & -18.5 & Enriched 1.1 per mil from August 1991 \\
\hline 143NO & February 1992 & -17.0 & - \\
\hline
\end{tabular}

${ }^{1}$ Well located outside the irrigated area.

Selenium is positively correlated with nitrate (fig. 21). When conditions in the ground water are reduced to the point where ammonia is the dominant nitrogen species, selenium is reduced out of the dissolved phase; hence, selenium and ammonia are negatively correlated (fig. 21). Iron goes into solution when oxidation-reduction conditions reach a point where ferrous iron $\left(\mathrm{Fe}^{2+}\right.$, the more soluble iron species) becomes the dominant iron species; oxidized selenium species become immobilized in such reducing conditions (fig. 21 ). The negative correlations of these oxidation-reduction-sensitive species with dissolved selenium in ground water indicates a high level of bacterial activity in the Mancos Shale that is capable of reducing selenium out of the dissolved phase. If not for irrigation, oxidationreduction conditions in the Mancos Shale would be sufficiently reducing to prevent the mobilization and transport of dissolved selenium.
The trace elements uranium and vanadium react similarly to oxidation-reduction conditions as does selenium. Selenium and uranium and selenium and vanadium, therefore, are positively correlated in water from wells in the Uncompahgre Project area and in the Grand Valley (fig. 21). Selenium and sulfate are positively correlated in water from wells in the Uncompahgre Project area and in the Grand Valley. Selenium is isomorphous with sulfur and substitutes in the crystalline structure of sulfide minerals; therefore, when pyrite in the Mancos Shale is oxidized by infiltrating irrigation water (putting sulfate into solution), selenium also is oxidized and brought into solution. Selenium precipitates with magnesium sulfate evaporite complexes; therefore, when evaporite complexes are dissolved by infiltrating irrigation water, selenium is put into solution. 

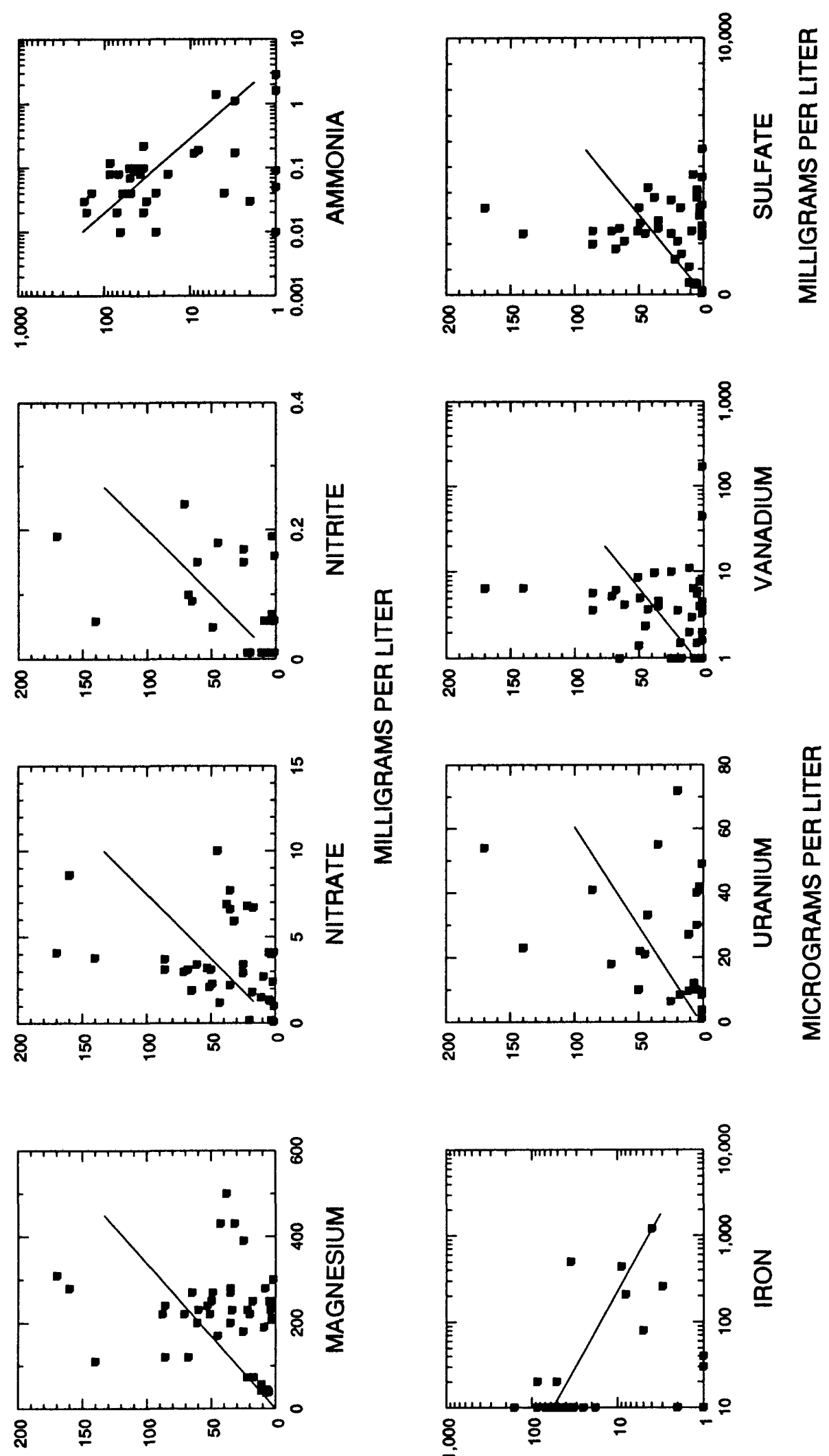

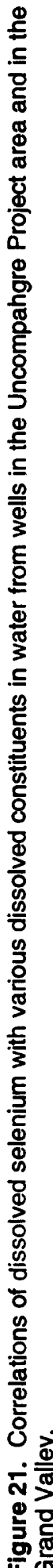

บ $\exists 117$ y

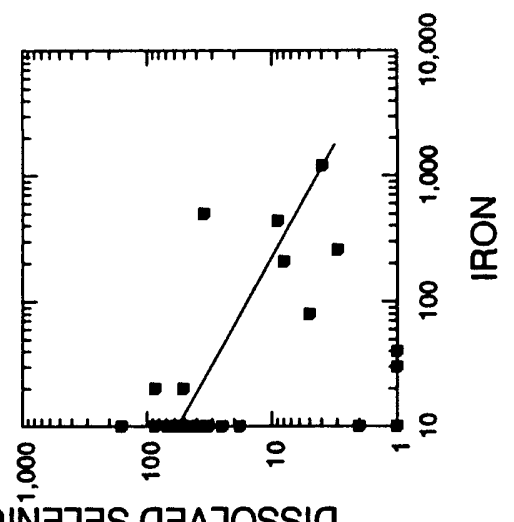




\section{SURFACE-WATER INVESTIGATIONS}

Selenium data for surface-water sites were used to determine areal and seasonal variations of selenium concentrations and loads in the irrigated areas. Selenium loads were used to delineate drainage basins that were major source areas of selenium discharging into the Gunnison and Colorado Rivers. Dissolved-solids and major-ion data were collected to describe general water quality and to determine if there were relations between concentrations of selenium and dissolved solids and major constituents in the study area. Data also were collected for other trace constituents and pesticides that could be potentially harmful to biota.

Sample collection in 1991 was essentially an expanded reconnaissance of the Uncompahgre Project area and a first-time reconnaissance of the Grand Valley to collect selenium and other trace-constituent data for streams, washes, and ditches draining irrigated areas. Selenium and other trace-constituent data for surface water in the study area were scarce, except from a few sites on the Gunnison and Colorado Rivers and from Sweitzer Lake. Also, there was a lack of information about selenium in irrigated areas outside the Uncompahgre Project in the lower Gunnison River Basin where irrigation drainage could be a source of selenium. During July 1991, samples were collected at 4 sites each on the Gunnison and Uncompahgre Rivers, at 17 sites on major streams or canals draining the Uncompahgre Project, and at 5 sites on tributaries of the Gunnison River that drain irrigated areas adjacent to or upstream from the Uncompahgre Project. For a reconnaissance of the Grand Valley, 20 sites were sampled in March and in late August-early September in 1991. Major tributary streams and washes of the Colorado River and selected smaller drainages were sampled to provide a general geographical distribution of sites in the Grand Valley. Samples for analysis of various insecticides were collected in the Grand Valley at 11 of the reconnaissance sites and at 2 sites on the Colorado River in the summer of 1991 . Water samples also were collected in June 1991 from three ponds in or adjacent to the Uncompahgre Project and from one pond in the Grand Valley.

In 1992, samples were analyzed for fewer constituents, and sampling focused on the irrigated areas in the Uncompahgre Project and in the Grand Valley. Data were collected for synoptic surveys during the winter of 1992 to describe the distribution of selenium and other constituent concentrations and loads in all major drainage basins and in selected drainage ditches in the irrigated areas. The synoptic data also were used to determine water-quality differences between and within basins. Samples for synoptic surveys for individual drainage basins were collected in 2 days, although sampling for all the surveys was done over about 7 weeks from late January to mid-March. In February 1992, streamdischarge data and water-quality samples were collected at 16 sites on the Uncompahgre River, including sites at all diversions for winter water, and at major inflows to estimate selenium and other constituent loading to the river during low and stable stream discharge. Monthly samples were collected at four tributary sites and from the Uncompahgre River in water year 1992 to describe seasonal variations in constituent concentrations and loads. Seleniumspeciation data were obtained for five streams in the Grand Valley in March 1992 for use in a risk assessment of selenate and selenite to endangered fish. Water samples were collected from two ponds in the Uncompahgre Project area and two ponds in the Grand Valley in June 1992.

\section{Sample Collection and Analytical Methods}

Onsite measurements at surface-water sites included stream discharge, specific conductance, $\mathrm{pH}$, water temperature, and dissolved oxygen. Water-quality measurements were made using methods similar to methods described by Knapton (1985). Stream discharge for sites at streamflowgaging stations was determined from the stage record and the stage-discharge rating table. Otherwise, stream discharge was measured using methods described by Rantz and others (1982).

Water samples were collected using depthintegrating samplers and equal-width methods (Ward and Harr, 1990) when possible. At sites where the water depth was too shallow, samples were collected from the centroid of flow or at several verticals in a cross section using 1-L plastic or glass bottles. Samples for selected organophosphate and carbamate insecticide analyses were collected directly in bottles supplied by the USGS National Water Quality Laboratory (NWQL) in Arvada, Colo. 
Samples collected for analyses of dissolvedinorganic constituents and uranium were filtered in the field through a $0.45-\mu \mathrm{m}$ cellulose filter using a plastic filter unit. Samples for analyses of inorganic constituents, uranium, and insecticides were processed and preserved for shipment to the NWQL according to standard procedures of the USGS. Samples for selenium-speciation analyses were acidified with hydrochloric acid and chilled with ice.

Quality-assurance sampling at surface-water sites included collection of three deionized water blanks that were filtered and processed as regular water samples, five sequential duplicate samples, and five split samples. Selenium was not detected in the blanks (less than $1 \mu \mathrm{g} / \mathrm{L}$ ). For the duplicate and split samples in which selenium concentrations exceeded $10 \mu \mathrm{g} / \mathrm{L}$, the difference between concentrations in the original sample and in the qualityassurance sample ranged from 3 to 12 percent. Except for uranium, the differences in other trace-constituent concentrations between duplicate or split samples generally were less than 10 percent.

The analyses of water samples for major constituents, nitrogen and phosphorus species, and trace constituents (except uranium) were done at the NWQL. Analytical methods described by Fishman and Friedman (1989) and laboratory quality-assurance methods described by Jones (1987) were used. Uranium was analyzed by a laboratory contracted by NWQL using a method described by Thatcher and others (1977). Insecticides in water were analyzed using methods described by Wershaw and others (1987). Stable isotopes of hydrogen and oxygen were analyzed using methods described by Epstein and Mayeda (1953) and Kendall and Coplen (1985). Selenium-speciation analyses of water samples were done by HGAAS (Fio and Fujii, 1990). The selenium-speciation analyses were done by the USGS in Sacramento, Calif. (R.F. Fujii, U.S. Geological Survey, written commun., 1992).

\section{Selenium Concentrations and Loads in the Gunnison and Colorado Rivers}

Selenium data have been collected since August 1975 at USGS streamflow-gaging stations on the Gunnison River at Whitewater (site GUN6) and on the Colorado River near the Colorado-Utah State line (site COL8) (fig. 1) for the USGS's National Stream Quality Accounting Network. Selenium data for the Gunnison River downstream from the Gunnison Tunnel (site GUN1), at Delta (site GUN4), and upstream from Escalante Creek (site GUN5) (fig. 1) were collected for the reconnaissance investigation of the Gunnison and Uncompahgre River Basins (Butler and others, 1991). Most of the selenium data for site GUN4 during water years 1991-92 were collected for another waterquality program of the USGS. Selenium data also were collected for the detailed study at selected gaging stations on the Gunnison and Colorado Rivers during 1991-92 to supplement ongoing data-collection activities.

\section{Selenium Concentrations}

Selenium concentrations for sites on the Gunnison and Colorado Rivers and for Plateau Creek (fig. 1) are summarized in table 15. Median selenium concentrations in the Gunnison and Colorado Rivers upstream from irrigated areas were less than $1 \mu \mathrm{g} / \mathrm{L}$ (table 15 ). That concentration also is representative of the selenium concentration in most of the irrigation-supply water for both areas, except for the Redlands area (fig. 3) in the Grand Valley, which is irrigated with water diverted from the Gunnison River downstream from site GUN6 (fig. 1). Selenium concentrations increase in the Gunnison and Colorado Rivers downstream from irrigated areas. The median concentrations at the two outflow sites for each river (sites GUN6 and COL8) are greater than at the sites upstream from the irrigated areas (table 15). Selenium concentrations in about 64 percent of the samples from site GUN6 and almost 50 percent of the samples from site COL8 exceeded the chronic aquatic-life criterion of $5 \mu \mathrm{g} / \mathrm{L}$ established by the U.S. Environmental Protection Agency (1987). The chronic criterion is a recommended guideline for protection of aquatic life from long-term exposure to selenium that could result in reproduction problems or mortality in fish and wildlife through food-chain bioaccumulation. The selenium concentrations in the lower Gunnison River and in the Colorado River in the Grand Valley area might be of concern in the recovery of endangered fish in the study area. Presently (1996), 
the FWS and BOR are studying locations along the Gunnison River downstream from Delta and along the Colorado River in the Grand Valley as possible recovery sites for endangered fish.

Analysis of the seasonal distribution of selenium concentrations (1975-92) at sites GUN6 and COL8 indicated maximum selenium concentrations occurred during August through October, which is the last one-half of the irrigation season. The selenium concentrations were slightly higher during the late irrigation season than during winter, although stream discharge was not necessarily lower in late summer than during winter at the two sites, particularly for the Colorado River. Minimum selenium concentrations occurred during May and June, coincident with the peak snowmelt runoff.

Time-series plots of selenium concentrations for the Gunnison River at Whitewater (site GUN6) and Colorado River near the Colorado-Utah State line (site COL8) are shown in figure 22. A smooth curve was fitted through the data points for each site using a LOWESS (LOcally WEighted Scatterplot Smoothing) procedure, which uses residual weighting functions to decrease the effect of outliers (Schertz and others, 1991). Generally, the smoothed curves indicate decreasing concentrations to about 1980 , a minimum in the mid-1980's, followed by a slight increase, and then relatively no change since about 1987. The low concentrations in the 1980's can be accounted for by dilution caused by high stream discharge in the Colorado River Basin from 1983 to 1986.

\section{A computer program called ESTREND} (EStimate TREND) (Schertz and others, 1991) was used to test the selenium data for monotonic time trends. The program uses a nonparametric test, the seasonal Kendall test, to examine water-quality data for monotonic trends. The seasonal Kendall test decreases the effect that seasonal differences in constituent concentrations could have on trend detection by comparing data from the same seasons of the year. For trend tests on selenium data, the year was divided into the nonirrigation season (November through March) and the irrigation season (April through October); the irrigation season was further divided into the runoff season (April through June) and the post-runoff season (July through October). The variability in stream discharge could mask or overwhelm trends in selenium concentrations. The ESTREND program computes trend statistics on the actual concentrations and on the flow(stream discharge) adjusted concentrations. Trend tests on flow-adjusted concentrations increase the chance of detecting a trend in concentrations that was the result of some effect other than a change in stream discharge.

Table 15. Summary of selenium concentrations in the Gunnison and Colorado Rivers and Plateau Creek and the number of samples exceeding aquatic-life criteria of the U.S. Environmental Protection Agency

[Concentrations in micrograms per liter; chronic aquatic-life criterion is 5 micrograms per liter, and the acute criterion is 20 micrograms per liter (U.S. Environmental Protection Agency, 1987); <, less than; a single value is listed for the range for one sample; --, no value]

\begin{tabular}{|c|c|c|c|c|c|c|c|}
\hline \multirow{2}{*}{$\begin{array}{c}\text { Site } \\
\text { number } \\
\text { (fig. 1) }\end{array}$} & \multirow{2}{*}{$\begin{array}{c}\text { Site } \\
\text { name }\end{array}$} & \multirow{2}{*}{$\begin{array}{l}\text { Period } \\
\text { of } \\
\text { record }\end{array}$} & \multirow{2}{*}{$\begin{array}{c}\text { Number } \\
\text { of } \\
\text { sampies }\end{array}$} & \multirow[t]{2}{*}{ Median } & \multirow[t]{2}{*}{ Range } & \multicolumn{2}{|c|}{$\begin{array}{l}\text { Number of sampies } \\
\text { exceeding criteria }\end{array}$} \\
\hline & & & & & & Chronic & Acute \\
\hline GUN1 & Gunnison River downstream from the Gunnison Tunnel & $1987-91$ & 5 & $<1$ & $<1-<1$ & 0 & 0 \\
\hline GUN3 & Gunnison River at Austin & 1991 & 1 & - & 1 & 0 & 0 \\
\hline GUN4 & Gunnison River at Delta & $1987-92$ & 13 & 4 & $<1-13$ & 2 & 0 \\
\hline GUN5 & Gunnison River upstream from Escalante Creek & $1987-91$ & 5 & 5 & $4-10$ & 2 & 0 \\
\hline GUN6 & Gunnison River at Whitewater & $1975-92$ & 73 & 7 & $<1-25$ & 47 & 1 \\
\hline COL2 & Colorado River near Cameo & $1980-92$ & ${ }^{1} 22$ & 1 & $<1-2$ & 0 & 0 \\
\hline COL5 & Colorado River upstream from Gunnison River & 1991 & 1 & -- & 2 & 0 & 0 \\
\hline COL8 & Colorado River near the Colorado-Utah State line & $1975-92$ & 75 & 5 & $<1-30$ & 37 & 1 \\
\hline PLT & Plateau Creek near mouth & $1991-92$ & 7 & $<1$ & $<1-2$ & 0 & 0 \\
\hline
\end{tabular}

${ }^{1}$ lncludes one sample collected in January 1992 at Palisade because of ice conditions at site COL2. 


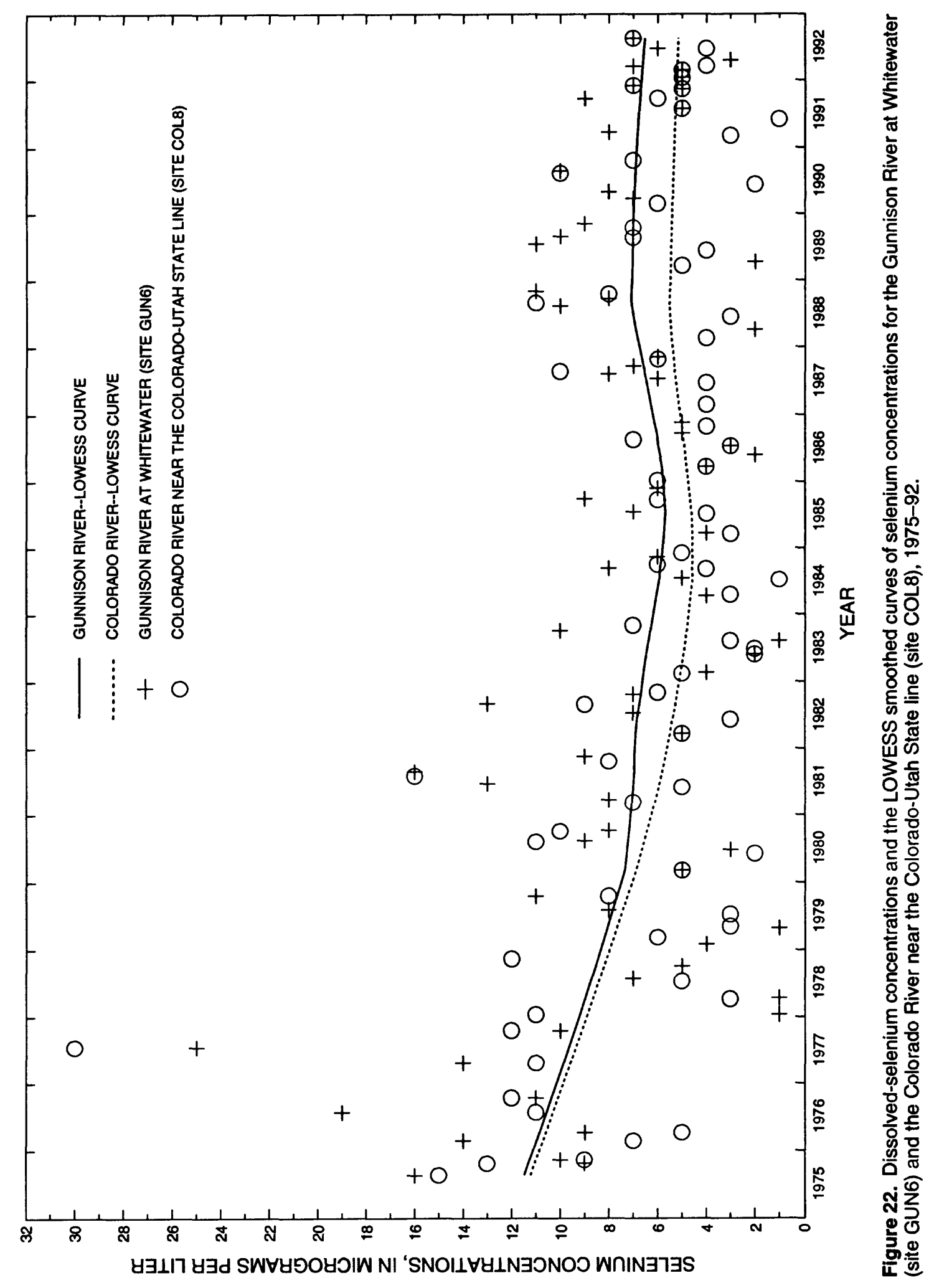


The ESTREND program was used to analyze the selenium data for $1975-92$ for the Gunnison River (site GUN6) and Colorado River (site COL8) for monotonic time trends. A trend was considered significant if the significance level (p) of the statistical test was $\mathbf{0 . 0 5}$ or less. For the Gunnison River, neither the trend in selenium concentrations of $-0.13(\mu \mathrm{g} / \mathrm{L}) / \mathrm{yr}$ was significant $(\mathrm{p}=0.28)$ nor was the trend in flow-adjusted concentrations of $-0.18(\mu \mathrm{g} / \mathrm{L}) / \mathrm{yr}$ significant $(\mathrm{p}=0.065)$. For comparative purposes, sulfate concentrations for 1975-92 also were analyzed for trends. Sulfate concentrations could be affected by irrigation drainage in the study area. For 1975-92, the concentration and flowadjusted concentration trends for sulfate were not significant for the Gunnison River, which is the same result as for the selenium data.

For the Colorado River, the trend in selenium concentrations of $-0.20(\mu \mathrm{g} / \mathrm{L}) / \mathrm{yr}(\mathrm{p}=0.003)$ and the trend in flow-adjusted concentrations of $-0.15(\mu \mathrm{g} / \mathrm{L}) / \mathrm{yr}(\mathrm{p}=0.005)$ were significant for 1975-92. Conversely, neither the concentration nor the flow-adjusted concentration trends for sulfate in the Colorado River for 1975-92 were significant. Because of the decrease in selenium concentrations in the Colorado River during the 1970's (fig. 22), trend analysis was done on the Colorado River selenium data for 1978-92, 1979-92, and 1980-92. For these three periods, the seleniumconcentration trends were not significant, but the flowadjusted concentration trends were still significant $[-0.14$ to $-0.16(\mu \mathrm{g} / \mathrm{L}) / \mathrm{yr}$ with $\mathrm{p}$ values of 0.002 to 0.006 ]. The trend results seem to indicate a decreasing trend in flow-adjusted selenium concentrations for the Colorado River downstream from the Grand Valley.

\section{Selenium Loads}

Selenium loads in the Gunnison River, Uncompahgre River, and tributaries of the Gunnison River were used to estimate the proportion of selenium load in the Gunnison River at Whitewater (site GUN6, the outflow site for the Gunnison River Basin) that is discharged from the Uncompahgre Project. To obtain such an estimate, the selenium loads in the Gunnison River at Delta (site GUN4), the Uncompahgre River at Delta (site UC16), and the
Gunnison River at Whitewater (fig. 23) were estimated. Estimates of selenium loading from the Uncompahgre Project into the Gunnison River between Peach Valley Arroyo and site GUN4 and between the Uncompahgre River and Roubideau Creek (fig. 23) also were made. Selenium-load estimates were considered approximate because of the limited quantity of selenium-load data for the Gunnison River and for tributaries.

Results of the sampling in July 1991 indicate that the selenium load in the Gunnison River increased from 5.6 to $23.1 \mathrm{lb} / \mathrm{d}$ between sites GUN3 and GUN4 (fig. 23). About 53 percent of the load in the Gunnison River at site GUN4 in July 1991 was accounted for in Peach Valley Arroyo (site PVA1), an unnamed drainage near Read (site RD1), and the Bonafide Ditch (site BFD) (fig. 23). Most of the selenium load from the three drainages was at sites RD1 and BFD. For three sets of samples collected at sites RD1, BFD, and GUN4 in 1992, the selenium loads at sites RD1 and BFD accounted for 29 to 45 percent of the selenium load at site GUN4. Unmeasured selenium loading into the Gunnison River between Peach Valley Arroyo and site GUN4 is from other ditches and drainages that discharge relatively small selenium loads from irrigated areas of the Uncompahgre Project and selenium loads from nonproject irrigated areas north of the river. Selenium data were collected for the detailed study in 1993 for tributaries of the Gunnsion River that drain the Uncompahgre Project (unpublished data, U.S. Geological Survey). For three sets of samples collected in the summer of 1993, about 53 percent of the selenium load at site GUN4 was accounted for by discharge from the Uncompahgre Project upstream from site GUN4. Based on selenium data collected during 1991-93, 50 percent of the selenium load at site GUN4 was assumed to be from the Uncompahgre Project.

Selenium loads for sites GUN4 and GUN6 and for site UC16 were estimated from daily selenium loads. Daily selenium loads were computed using predicted selenium concentrations from regression relations of selenium concentration to stream discharge and from the daily mean stream discharge for water years 1991-92. Regression relations had coefficient of determinations ranging from 0.52 to 0.82 (all significance levels were less than 0.05 ). 


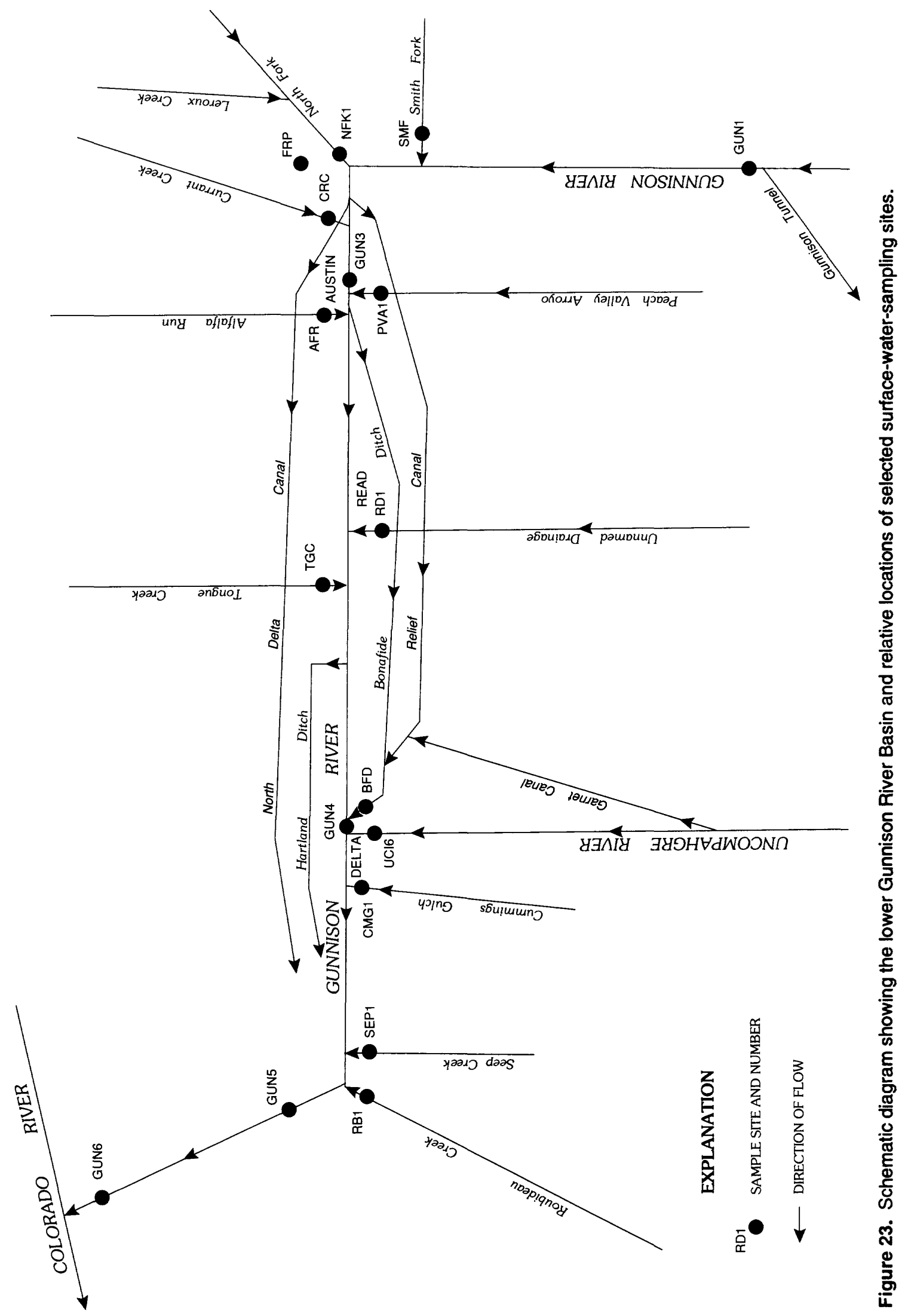

52 Detailed Study of Selenlum and Other Constituents In Water, Bottom Sediment, Soll, Alfalfa, and Biota Assoclated with Irrigation Drainage in the Uncompahgre Project Area and In the Grand Valley, West-Central Colorado, $1991-93$ 
Fifty percent of the difference in selenium load between sites GUN4 and GUN6, minus the load for site UC16, was assumed to be selenium loading from the Uncompahgre Project into the Gunnison River between the Uncompahgre River and Roubideau Creek (fig. 23). That estimate is derived from selenium data collected in 1991-92 (Butler and others, 1994) and from data collected in 1993 (unpublished data, U.S. Geological Survey). Selenium loads for the Uncompahgre River (discussed in the "Selenium Loads" section) indicate that about 95 percent of the selenium load in the river at site UC16 was from the Uncompahgre Project. The fraction of the selenium load at site GUN6 attributable to the Uncompahgre Project was computed using: [ 0.5 times the selenium load at site GUN4) plus ( 0.95 times the selenium load at site UC16) plus ( 0.5 times the difference in selenium load between sites GUN6 minus GUN4 and UC16)] divided by the selenium load at site GUN6. Using the periodic selenium and daily stream-discharge data for water years 1991-92, the Uncompahgre Project accounted for about 68 percent of the selenium load in the Gunnison River at Whitewater (site GUN6). That estimate is considered a general approximation because of the limited selenium-loading data for streams, washes, and ditches that discharge into the Gunnison River between sites GUN3 and Roubideau Creek.

Selenium loads in the Gunnison River at Whitewater (site GUN6) and in the Colorado River near the Colorado-Utah State line (site COL8) in water years 1991-92 for samples collected within 2 days of each other are shown in figure 24. Site COL8 is the outflow site for the entire study area and is downstream from all irrigation drainage from the Gunnison River Basin and from the Grand Valley. The residual selenium load shown in figure 24 is equal to the selenium load of the Colorado River at site COL8 minus the load for the Gunnison River at site GUN6. The residual load represents the selenium load in the Colorado River upstream from the Grand Valley plus the selenium load from the Grand Valley. The selenium load in the Colorado River upstream from the Grand Valley is essentially equal to the selenium load in the Colorado River at site COL2 (fig. 1), plus the small load from Plateau Creek (site PLT). Because ungaged surface- and ground-water dissolved-solids loads from natural sources into the Grand Valley are negligible (Bureau of Reclamation, 1983), selenium loads from natural sources in the Grand Valley also are assumed to be negligible. Therefore, selenium loading from the Grand Valley was assumed to be from irrigation-induced sources.

A regression of selenium concentration to stream discharge using data for 1991-92 was determined for the Colorado River at site COL8 and then used to estimate daily mean selenium loads for that site. The stream discharge for the Colorado River upstream from the Grand Valley was equal to the combined stream discharge of the Colorado River at site COL2 and Plateau Creek at site PLT (fig. 1). About 75 percent of the selenium concentrations were reported as less than $1 \mu \mathrm{g} / \mathrm{L}$ in samples collected in 1991-92 at sites COL2 and PLT. An arbitrary mean selenium concentration of $0.7 \mu \mathrm{g} / \mathrm{L}$ was used to compute the daily mean selenium loads in the Colorado River upstream from the Grand Valley. The selenium-load estimates for water years 1991-92 indicate that the Colorado River upstream from the Grand Valley accounted for about 10 percent of the selenium load at site COL8, the Gunnison River (site GUN6) accounted for about 45 percent of the load, and the Grand Valley accounted for the remaining 45 percent of the selenium load in the Colorado River.

These selenium-load estimates for the Gunnison and Colorado Rivers are considered approximations, but might be useful for comparing relative contributions of the Uncompahgre Project and the Grand Valley with the selenium load in the Colorado River. About two-thirds of the selenium load in the Gunnison River at site GUN6 was attributed to the Uncompahgre Project; therefore, the Uncompahgre Project accounts for about 30 percent of the selenium load in the Colorado River at site COL8. The Grand Valley accounts for about 45 percent of the selenium load in the Colorado River at site COL8. Although the uncertainty associated with these estimates was not determined, the seleniumloading estimates indicate that the Uncompahgre Project and the Grand Valley are major sources of selenium to the Colorado River.

Longer term selenium loads in the Gunnison River and from the Grand Valley were estimated by using the selenium data collected during water years 1976-92 for sites GUN6 and COL8 (fig. 22). The same methods used for estimating selenium loads for the Colorado River upstream from the Grand Valley and for sites GUN6 and COL8 for water years 1991-92 were used to estimate selenium 


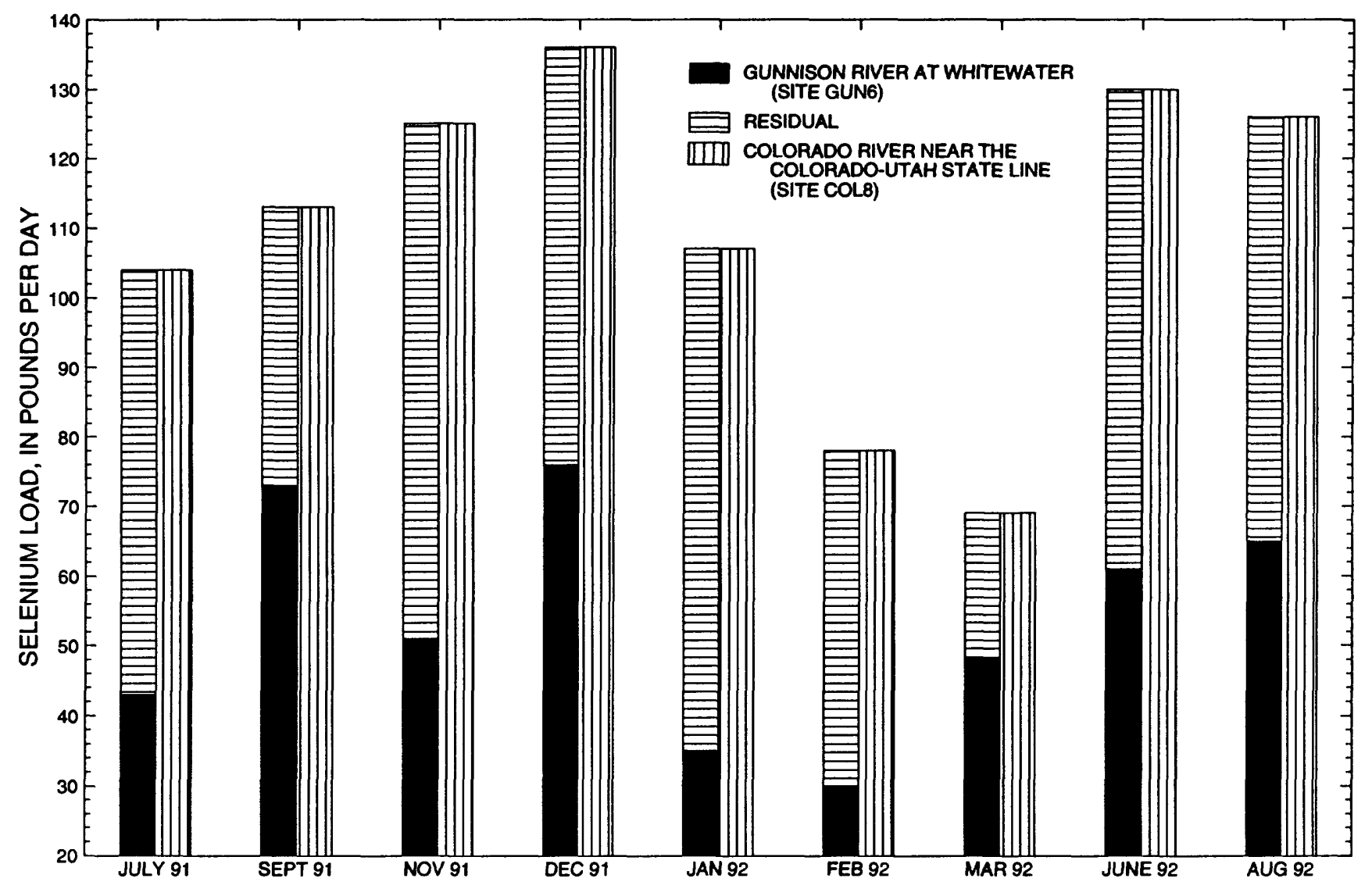

Figure 24. Selenium loads in the Gunnison River at Whitewater (site GUN6) and the Colorado River near the ColoradoUtah State line (site COL8), July 1991-August 1992, and the residual loads. (Only samples collected at both sites in the same week are shown. Residual is the selenium load at site COL8 minus the selenium load at site GUN6.)

loads for water years 1976-92. The selenium load in the Colorado River upstream from the Grand Valley accounted for about 9 percent, the Gunnison River about 43 percent, and the selenium load from the Grand Valley about 48 percent of the selenium load in the Colorado River at site COL8. The results for the Gunnison River and Grand Valley selenium loads for water years 1976-92 are comparable to the estimates for water years 1991-92.

\section{Distribution, Magnitude, and Variation of Selenium Concentrations}

Distribution, magnitude, and variation of selenium concentrations are described for irrigated areas in the Uncompahgre Project and in the Grand Valley and in areas adjacent to the Uncompahgre Project. Selenium concentrations are compared to aquatic-life criteria established by the U.S. Environmental Protection Agency (1987).
Irrigation drainage is considered the groundwater component of water in streams, washes, canals, and ditches within the irrigated areas. Surface-return flow is defined as the irrigation water from field runoff and the excess water in the canals and laterals that was discharged into streams and washes during the irrigation season. Winter water is water that was diverted from streams into canals and laterals during the nonirrigation season (November-March) for livestock water supplies. Unused winter water also was discharged into the streams and washes and essentially is equivalent to surface-return flow.

\section{Uncompahgre Project Area}

\section{Tributaries, Canals, and Ditches}

All water samples collected during the nonirrigation season from the east side of the Uncompahgre Project exceeded the chronic aquatic-life criterion of $5 \mu \mathrm{g} / \mathrm{L}$ and all but one sample exceeded the acute 
criterion of $20 \mu \mathrm{g} / \mathrm{L}$ (table 16). Sampling sites are shown in schematic diagrams for the Uncompahgre Project in figures 25 and 26. The schematic diagrams show major streams, washes, canals, and miscellaneous ditches. Eight of the 11 irrigation-season samples from the eastern side that exceeded the acute criterion were monthly samples collected from Loutsenhizer Arroyo at site LZA1 (fig. 26). Selenium concentrations in about one-half the nonirrigationseason water samples from the western side exceeded $5-\mu \mathrm{g} / \mathrm{L}$ chronic criterion, but only three concentrations exceeded the $20 \mu \mathrm{g} / \mathrm{L}$ acute criterion. Although surface-return flow diluted selenium concentrations during the irrigation season, aimost all selenium concentrations in irrigation-season samples from the eastern side exceeded the chronic aquatic-life criterion (table 16). The three samples from the eastern side that had selenium concentrations that did not exceed the chronic aquatic-life criterion were collected from Gretts, Markley, and Brozina Ponds (sites GTP, MKP, and BZP in fig. 26). The source water for these ponds is irrigation-supply water, surface-return flow, and irrigation drainage. Chemical and biological processes might remove some selenium from water in the ponds and immobilize the selenium in bottom sediment (Lemly and Smith, 1987).

Selenium concentrations were much higher in surface water on the eastern side of the Uncompahgre Project (east of the Uncompahgre River) than on the western side (table 16). The larger selenium concentrations on the eastern side of the Uncompahgre Project primarily are the result of geologic differences between the eastern and western sides (fig. 4). About 85 percent of the irrigated land on the eastern side is on soils primarily derived from Mancos Shale (adobe soils), but only about 4 percent of the irrigated land on the western side is on adobe soils (Bureau of Reclamation, 1982). Most of the irrigated land on the western side is on soils derived from terrace deposits and the Dakota Sandstone that probably contain none or small amounts of shale detritus. Geometric mean concentrations of total and water-extractable selenium were about 2 to 5 times greater for soils derived from the Mancos Shale than for soils derived from the Dakota Sandstone or terrace deposits (table 2).

An analysis of the distribution of selenium concentrations in the Uncompahgre Project during the nonirrigation season was done by examination of the data collected for the synoptic surveys in 1992. Selenium concentrations in samples collected for the synoptic surveys were much higher on the eastern side of the project than on the western side (table 17). Selenium concentrations in each sample collected during synoptic surveys are shown on the schematic diagrams in figures 25 and 26. Major drainage basins, selected ditches, and canals that had winter water were sampled during synoptic surveys. Excluding winter-water samples (coded WW in table 17), median selenium concentrations for synoptic-survey samples collected in the major drainage basins and geographical areas on the eastern side of the Uncompahgre Project ranged from 59 to $170 \mu \mathrm{g} / \mathrm{L}$, compared to 1 to $16 \mu \mathrm{g} / \mathrm{L}$ for the western side of the project.

Table 16. Summary of selenium concentrations in irrigated areas of the Uncompahgre Project in 1991-92 and the number of samples that exceeded aquatic-life criteria of the U.S. Environmental Protection Agency

[Concentrations in micrograms per liter; west and east irrigated areas separated by the Uncompahgre River; irrigation-season samples were collected in July and October 1991 and April through August 1992; nonirrigation-season samples were collected from November 1991 through March 1992; chronic aquatic-life criterion is 5 micrograms per liter, and the acute criterion is 20 micrograms per liter (U.S. Environmental Protection Agency, 1987); <, less than]

\begin{tabular}{|c|c|c|c|c|c|c|}
\hline \multirow[t]{2}{*}{ Area } & \multirow[t]{2}{*}{ Season } & \multirow{2}{*}{$\begin{array}{c}\text { Number } \\
\text { of } \\
\text { samples }\end{array}$} & \multirow[t]{2}{*}{ Median } & \multirow[t]{2}{*}{ Range } & \multicolumn{2}{|c|}{$\begin{array}{l}\text { Number of samples } \\
\text { exceeding criteria }\end{array}$} \\
\hline & & & & & Chronic & Acute \\
\hline West & Irrigation & 14 & 1.5 & $<1-9$ & 4 & 0 \\
\hline West & Nonirrigation & 37 & 5 & $<1-55$ & 18 & 3 \\
\hline East & Irrigation & 36 & 11 & $2-56$ & 33 & 11 \\
\hline
\end{tabular}




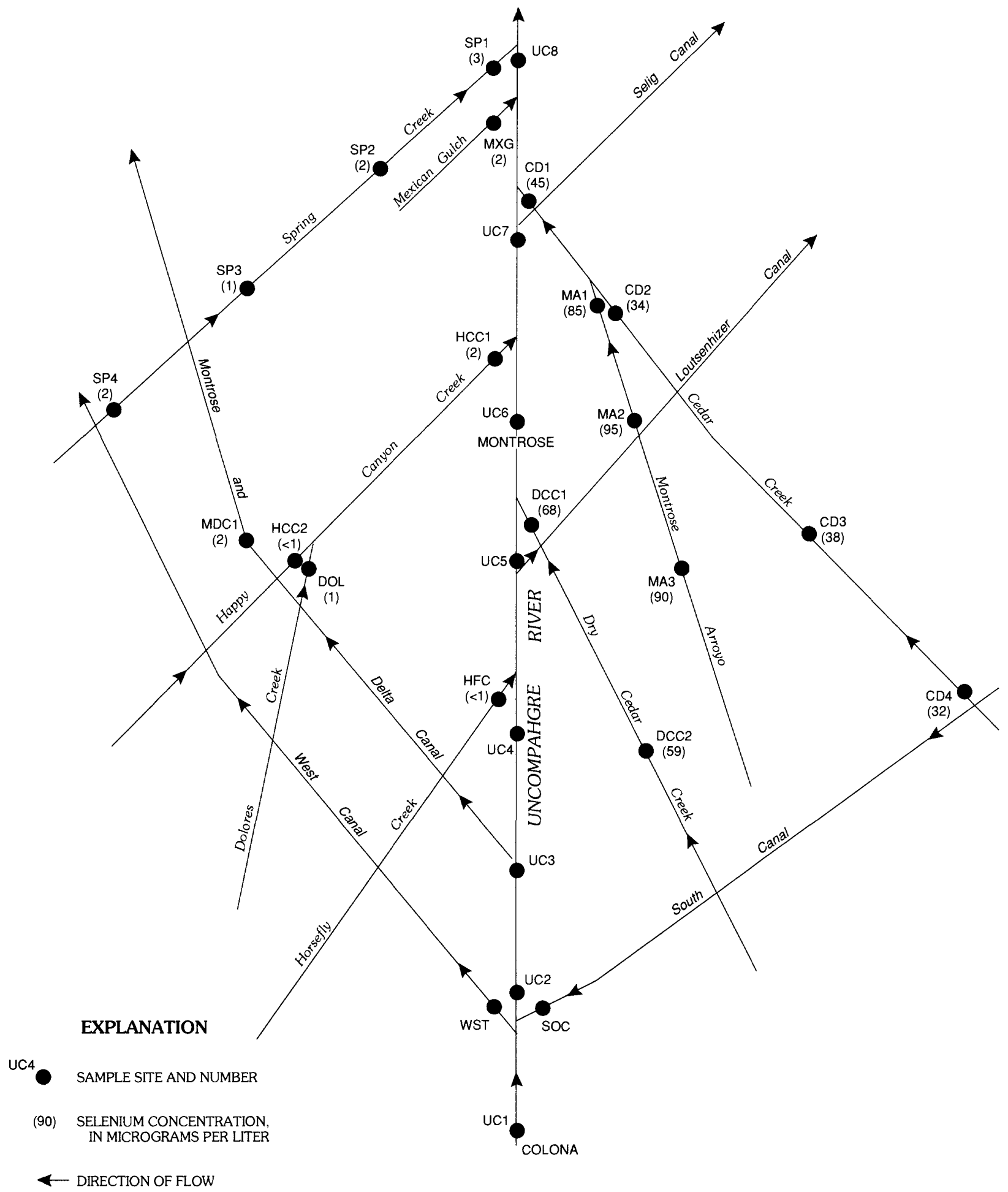

Figure 25. Schematic diagram showing the southern part of the Uncompahgre Project, relative locations of surface-water-sampling sites, and selenium concentrations in samples collected during synoptic surveys, January-March, 1992. 


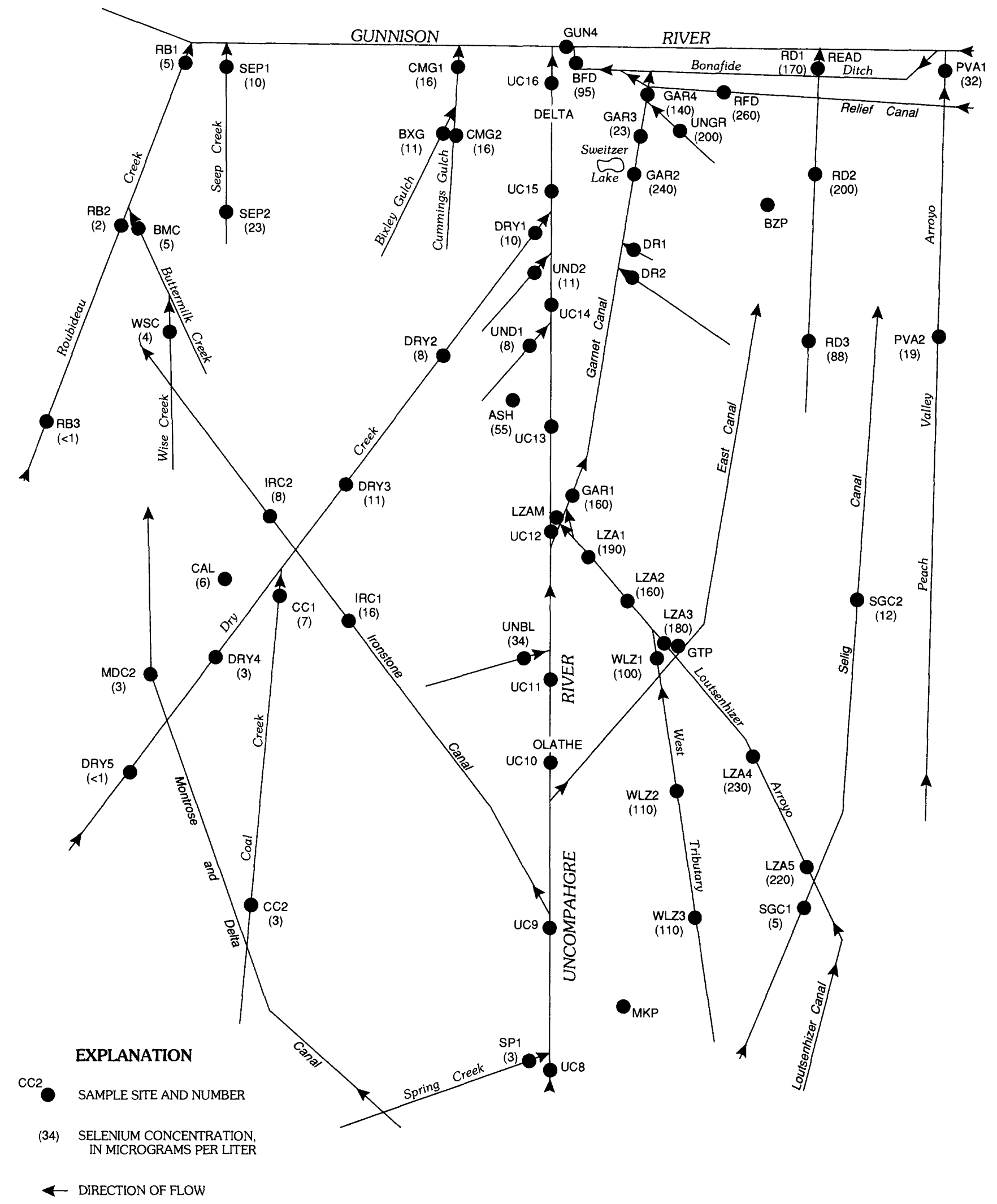

Figure 26. Schematic diagram showing the northern part of the Uncompahgre Project, relative locations of surface-watersampling sites, and selenium concentrations in samples collected during synoptic surveys, January-March 1992. 
Table 17. Summary of selenium concentrations in samples collected during the synoptic surveys of the Uncompahgre Project, January through March 1992

[Concentrations in micrograms per liter; (WW), winter-water samples; $<$, less than]

\begin{tabular}{lcccc}
\hline \multicolumn{1}{c}{$\begin{array}{c}\text { Drainage basin } \\
\text { or canal }\end{array}$} & $\begin{array}{c}\text { Number } \\
\text { of sites }\end{array}$ & $\begin{array}{c}\text { Sites included } \\
\text { (flgs. 25 and 26) }\end{array}$ & Median & Range \\
\hline & AREAS WEST OF THE UNCOMPAHGRE RIVER & & $2-3$ \\
West Canal/Montrose and Delta Canal (WW) & 4 & WST, UC3, MDC1, MDC2 & 2.5 & $8-16$ \\
Ironstone Canal (WW) & 3 & UC9, IRC1, IRC2 & 11.5 & $<1-2$ \\
Horsefly and Happy Canyon Creek Basins & 4 & HFC, HCC1, HCC2, DOL & 1 & $1-3$ \\
Spring Creek Basin and Mexican Gulch & 5 & SP1-SP4, MXG & 2 & $<1-10$ \\
Dry Creek Basin & 7 & DRY1-DRY5, CC1, CC2 & 7 & $6-55$ \\
Miscellaneous ditches & 5 & UNBL, CAL, ASH, UND1, UND2 & 9.5 & $10-23$ \\
Cummings Gulch and Seep Creek Basins & 5 & CMG1, CMG2, BXG, SEP1, SEP2 & 16 & $<1-5$ \\
Roubideau Creek Basin & 5 & RB1-RB3, BMC, WSC & 4 & \\
& AREAS EAST OF THE UNCOMPAHGRE RIVER & & $5-12$ \\
Selig Canal (WW) & 3 & UC7, SGC1, SGC2 & 9 & $32-95$ \\
Dry Cedar and Cedar Creek Basins & 9 & DCC1, DCC2, CD1-CD4, MA1-MA3 & 59 & $100-230$ \\
Loutsenhizer Arroyo Basin & 8 & LZA1-LZA5, WLZ1-WLZ3 & 170 & $19-200$ \\
Peach Valley Arroyo and unnamed drainage & 5 & PVA1, PVA2, RD1-RD3 & 88 & $23-260$ \\
Garnet Canal and Bonafide Ditch & 7 & GAR1-GAR4, UNGR, RFD, BFD & 160 & \\
\hline
\end{tabular}

Perhaps one reason for lower selenium concentrations on the western side of the Uncompahgre Project during the nonirrigation season was dilution of subsurface-irrigation drainage by winter water. Winter water was discharged into all of the major tributaries on the western side of the Uncompahgre Project during collection of samples for the synoptic surveys in early 1992. The sole source of winter water in canals was water diverted from the Uncompahgre River. During the synoptic sampling in 1992, winter water was diverted only into the Selig Canal on the eastern side and into all three canals that serve the western side of the project (figs. 25 and 26). Analysis of the selenium concentrations in streams and in winter water (table 17) and of selenium concentrations in ground-water samples from the Dry and Spring Creek Basins does not indicate that dilution by winter water is the only cause of lower selenium concentrations on the western side during the nonirrigation season. The similarity of selenium concentrations between winter water and major streams on the western side (figs. 25 and 26; table 17) indicates that either most of the water in the streams consisted of winter water or that selenium concentrations in irrigation drainage that discharged into western-side streams and ditches were not markedly different than concentrations in winter water. For example, a comparison of selenium concentrations in Dry Creek with concentrations in winter water in the Ironstone Canal and in the Montrose and Delta Canal was made using figures 25 and 26. The samples at sites IRC1, $\mathrm{MDC} 1$, and MDC2 were collected during the same 2 days as the samples from Dry Creek. Water samples from Dry Creek represented mixtures of irrigation drainage, winter water, and small quantities of natural flow. The selenium concentrations in Dry Creek at sites DRY1, DRY2, and DRY3 ranged from 8 to $11 \mu \mathrm{g} / \mathrm{L}$ in February (fig. 26), and these sites are downstream from the Ironstone Canal and its laterals. At site DRY4, which could only receive winter water from the Montrose and Delta Canal, the selenium concentration was $3 \mu \mathrm{g} / \mathrm{L}$. The relatively high selenium concentrations (for the western side) in the Cummings Gulch and Seep Creek Basins (table 17) could partly be the result of transport of winter water into those basins by laterals from the Ironstone Canal.

The water samples from sites ASH, UNBL, and SEP2 (fig. 26) were the only samples from the western side in which selenium concentrations ( 23 to $55 \mu \mathrm{g} / \mathrm{L}$ ) were substantially greater than concentrations in winter water. Most of the water sampled at these 
three sites was assumed to be irrigation drainage because of the small stream discharges (less than $0.5 \mathrm{ft}^{3} / \mathrm{s}$ ) and because dissolved-solids concentrations were much higher in these drainages than in winter water diverted from the Uncompahgre River. Those three sites are near or in areas where soils could contain detritus from the Mancos Shale. Although irrigation drainage from Mancos Shale areas on the western side can contain substantial selenium concentrations, areas on Mancos Shale represent only about 4 percent of the irrigated area west of the Uncompahgre River.

The highest selenium concentrations during the nonirrigation season on the eastern side of the Uncompahgre Project generally were in the Loutsenhizer Arroyo Basin, in an unnamed drainage near Read, and in the Garnet Canal area (fig. 26; table 17). The small amount of winter water in the Selig Canal ( $7.5 \mathrm{ft}^{3} / \mathrm{s}$ in March 1992) probably did not have a major effect on selenium concentrations in streams on the eastern side of the project. The synoptic-survey data (figs. 25 and 26 ) indicate that selenium concentrations on the eastern side of the Uncompahgre Project had large variability among sites and within drainage basins during the nonirrigation season. For example, the maximum selenium concentration in surface-water samples collected in 1991-92 in the Uncompahgre Project area was $260 \mu \mathrm{g} / \mathrm{L}$ for site $\mathrm{RFD}$, and a sample collected from a nearby natural drainage at site UNGR had $200 \mu \mathrm{g} / \mathrm{L}$ of selenium (fig. 26). By contrast, the synoptic-survey sample collected from the Garnet Canal at site GAR3 (fig. 26), about 2 mi southwest of site RFD, had only $23 \mu \mathrm{g} / \mathrm{L}$ of selenium. The synoptic-survey samples were collected within a 2-day period in March 1992 at sites RFD, UNGR, and GAR3, and the sole water source at those sites was subsurface-irrigation drainage. There also were major differences in selenium concentrations in the Cedar Creek and Loutsenhizer Arroyo Basins (figs. 25 and 26).

Water from the Garnet Canal is used to keep Sweitzer Lake full during the year. During the irrigation season, water from the Uncompahgre River and Loutsenhizer Arroyo is used to fill the Garnet Canal. Historically, there were periods of insufficient flow in the Uncompahgre River at the Garnet diversion to fill the canal during the irrigation season. Therefore, a diversion from Loutsenhizer Arroyo is used (at site LZAM in fig. 26) to divert some of the water in the arroyo into the Garnet Canal to supplement the river diversion. During the nonirrigation season, the river diversion is closed, and a small quantity of water from Loutsenhizer Arroyo usually flows into the canal and is discharged into Sweitzer Lake. As a result, irrigation drainage having some of the highest selenium concentrations in the Uncompahgre Project area discharges into Sweitzer Lake.

Selenium concentrations seem to be further increased in the Garnet Canal upstream from Sweitzer Lake by the discharge of irrigation drainage that contains high selenium concentrations into the canal between site GAR1 and the diversion into Sweitzer Lake at site GAR2. The water sample collected in March 1992 at site GAR1 consisted solely of water diverted from Loutsenhizer Arroyo. The selenium concentration increased from 160 to $240 \mu \mathrm{g} / \mathrm{L}$ between sites GAR1 and GAR2 (fig. 26), and the discharge in the canal increased by about $0.4 \mathrm{ft}^{3} / \mathrm{s}$. In March 1993, two drainage ditches located about $0.4 \mathrm{mi}$ south of Sweitzer Lake at sites DR1 and DR2 (fig. 26) were sampled. Site DR1 is on a small ditch draining a seep area near the canal, and site DR2 is on a drainage ditch that extends to the east and southeast of the Garnet Canal. Both ditches discharge directly into the canal. On March 2, 1993, a sample from site DR2 had a selenium concentration of $600 \mu \mathrm{g} / \mathrm{L}$. On March 24, a sample from site DR1 had a selenium concentration of $73 \mu \mathrm{g} / \mathrm{L}$, and a sample from site DR2 had a concentration of $520 \mu \mathrm{g} / \mathrm{L}$. The selenium concentrations for site DR2 were much higher than the maximum selenium concentration of $260 \mu \mathrm{g} / \mathrm{L}$ (at site RFD) for the surface-water samples collected in 1991-92 in the Uncompahgre Project area. Stream discharge at site DR1 was about $0.01 \mathrm{ft}^{3} / \mathrm{s}$ and at site DR2 about $0.10 \mathrm{ft}^{3} / \mathrm{s}$. Visual observations of flow in the Garnet Canal seem to indicate that various reaches in the canal upstream and downstream from sites DR1 and DR2 were gaining or losing water. Apparently, discharge of irrigation drainage from the drainage ditch at site DR2 and from nonpoint seepage into the canal caused the higher selenium concentrations in the Garnet Canal at the Sweitzer Lake diversion (site GAR2) than in the canal at site GAR1.

Selenium concentrations in eastern-side drains were much lower during the irrigation season compared to the nonirrigation season (sites CD1, LZA1, and RD1 in fig. 27). Large quantities of surface irrigation-return flow dilute selenium concentrations in eastern-side drains during the irrigation 
season. Stream discharges measured at the time of sampling were about 5 to 15 times greater during the irrigation season than during the nonirrigation season for the samples shown in figure 27. The ranges of instantaneous stream discharges measured in eastern-side streams were 15.4 to $215 \mathrm{ft}^{3} / \mathrm{s}$ for Cedar Creek (11 measurements at site CD1), 13.3 to $109 \mathrm{ft}^{3} / \mathrm{s}$ for Loutsenhizer Arroyo (13 measurements at site LZA1), and 4.9 to $76 \mathrm{ft}^{3} / \mathrm{s}$ for the unnamed drainage near Read (6 measurements at site RD1). Despite the dilution effect by surface-return flows during the irrigation season, selenium concentrations in all water samples from Loutsenhizer Arroyo at site LZA1 exceeded the acute aquatic-life criterion of $20 \mu \mathrm{g} / \mathrm{L}$ (U.S. Environmental Protection Agency, 1987) (fig. 27).
Selenium concentrations had much less seasonal variation in western-side streams than in easternside streams, as indicated by the small range of concentrations (4 to $10 \mu \mathrm{g} / \mathrm{L}$ ) in Dry Creek at site DRY1 (fig. 27). The range in stream discharge for 11 instantaneous stream-discharge measurements at site DRY1 (July 1991 to June 1992) was 51.9 to $200 \mathrm{ft}^{3} / \mathrm{s}$. Selenium concentrations were only slightly lower in the samples collected in July 1991 compared to samples collected in the winter of 1992 at the outflow sites on Horsefly Creek (site HFC), Happy Canyon Creek (site HCC1), Spring Creek (site SP1), Cummings Gulch (site CMG1), and Roubideau Creek (site RB1), although stream discharge averaged about five times greater for samples collected in July 1991 than for samples from the winter of 1992.

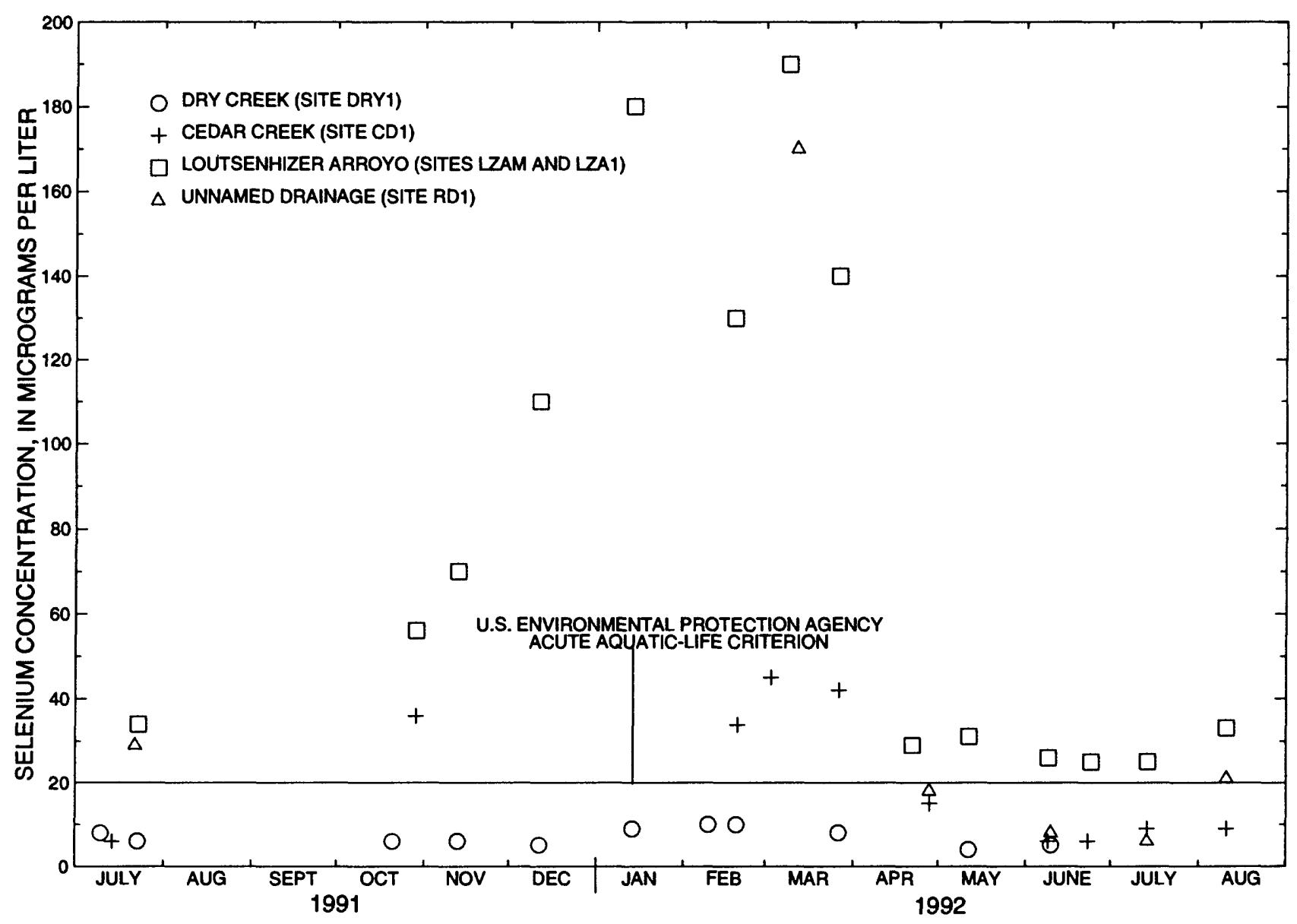

Figure 27. Selenium concentrations in samples from Dry Creek at site DRY1, Cedar Creek at site CD1, Loutsenhizer Arroyo at sites LZAM and LZA1, and an unnamed drainage at site RD1, July 1991-August 1992. 


\section{Uncompahgre Rlver}

Samples were collected approximately monthly from May 1991 to August 1992 at the outflow site for the Uncompahgre River at Delta (site UC16 in fig. 26), and all selenium data collected at site UC16 since 1987 are shown in figure 28 . The median selenium concentration in the Uncompahgre River at site UC16 was $15 \mu \mathrm{g} / \mathrm{L}$. Concentrations generally were higher during the nonirrigation season (November through March) than during the irrigation season. Selenium concentrations throughout the Uncompahgre Project would have been diluted during the irrigation season because of the import of about $1,000 \mathrm{ft}^{3} / \mathrm{s}$ of water from the Gunnison River that had less than $1 \mu \mathrm{g} / \mathrm{L}$ of selenium. Except for two samples, selenium concentrations in water samples collected at site UC16 exceeded the chronic criterion for aquatic life $(5 \mu \mathrm{g} / \mathrm{L})$, and seven of the concentrations exceeded the acute criterion of $20 \mu \mathrm{g} / \mathrm{L}$ (fig. 28). By comparison, the median selenium concentration for 14 samples collected during 1987-92 from the Uncompahgre River at Colona (site UC1 in fig. 25), which is upstream from irrigated areas of the Uncompahgre Project, was $1 \mu \mathrm{g} / \mathrm{L}$, and the maximum concentration was $2 \mu \mathrm{g} / \mathrm{L}$.

Results of a gain-loss study of the Uncompahgre River on February 19-20, 1992, indicated that selenium concentrations increased noticeably in only 3 of the 15 sampled reaches between sites UC1 and UC16 (fig. 29). Stream discharge was measured and water samples were collected at 16 sites on the Uncompahgre River (fig. 29). Relative locations are shown in figures 25 and 26. Winter-water diversions from the Uncompahgre River were measured and sampled at site WST (West Canal at Highway 550), site UC3 (Montrose and Delta Canal), site UC7 (Selig Canal), and site UC9 (Ironstone Canal). The three reaches of the river that had conspicuous increases in selenium concentrations coincided with inflow from Dry Cedar Creek (reach UC5-UC6), Cedar Creek (reach UC7-UC8), and Loutsenhizer Arroyo (reach UC12-UC13) (figs. 25, 26, and 29). Inflow from western-side streams either caused no change in selenium concentrations or diluted the concentrations in the Uncompahgre River. The large decrease in concentration between sites UC14 and UC15 was caused by Dry Creek, which almost doubled the stream discharge of the Uncompahgre River. Data collected for the gain-loss study indicated that the largest selenium concentrations in the Uncompahgre River occurred in the reach between Loutsenhizer Arroyo and Dry Creek and not at the outflow site in Delta (site UC16).

\section{Adjacent Areas In the Lower Gunnison River Basin}

Selenium data were collected once, in July 1991, in selected drainage basins in the lower Gunnison River Basin to document selenium concentrations in irrigated areas adjacent to the Uncompahgre Project. Samples were collected from five streams draining irrigated areas in the lower Gunnison River Basin: Smith Fork (site SMF), North Fork (site NFK1), Currant Creek (site CRC), Alfalfa Run (site AFR), and Tongue Creek (site TGC) (fig. 23). Since December 1990, the USGS has collected periodic selenium data at a gaging station on lower Leroux Creek (fig. 23), which drains irrigated areas in the lower North Fork Basin. Selenium was not detected in water samples from the Smith Fork nor in Alfalfa Run (fig. 23). Selenium was detected in samples from the North Fork $(4 \mu \mathrm{g} / \mathrm{L})$, Currant Creek $(19 \mu \mathrm{g} / \mathrm{L})$, and Tongue Creek $(6 \mu \mathrm{g} / \mathrm{L})$. The range of selenium concentrations in nine samples from Leroux Creek was 7 to $21 \mu \mathrm{g} / \mathrm{L}$. Although many of the samples were collected in summer, the samples collected at the latter four sites were at relatively low stream discharge. Upstream diversions for irrigation depleted water in the lower North Fork, Leroux, Currant, and Tongue Creek Basins during summer.

\section{Grand Valley}

There was a large range of selenium concentrations in irrigated areas of the Grand Valley (table 18). The samples summarized in table 18 include all samples collected from streams, washes, drainage ditches, and ponds located in irrigated areas of the Grand Valley, excluding the Colorado River.

Sampling sites are shown on the schematic diagrams in figures 30 and 31 . Selenium concentrations in samples collected during the nonirrigation season in the Grand Valley exceeded the chronic aquatic-life criterion of $5 \mu \mathrm{g} / \mathrm{L}$ (U.S. Environmental Protection Agency, 1987) in 73 of 76 samples, and selenium concentrations exceeded the acute criterion of $20 \mu \mathrm{g} / \mathrm{L}$ in about 82 percent of the samples (table 18). 


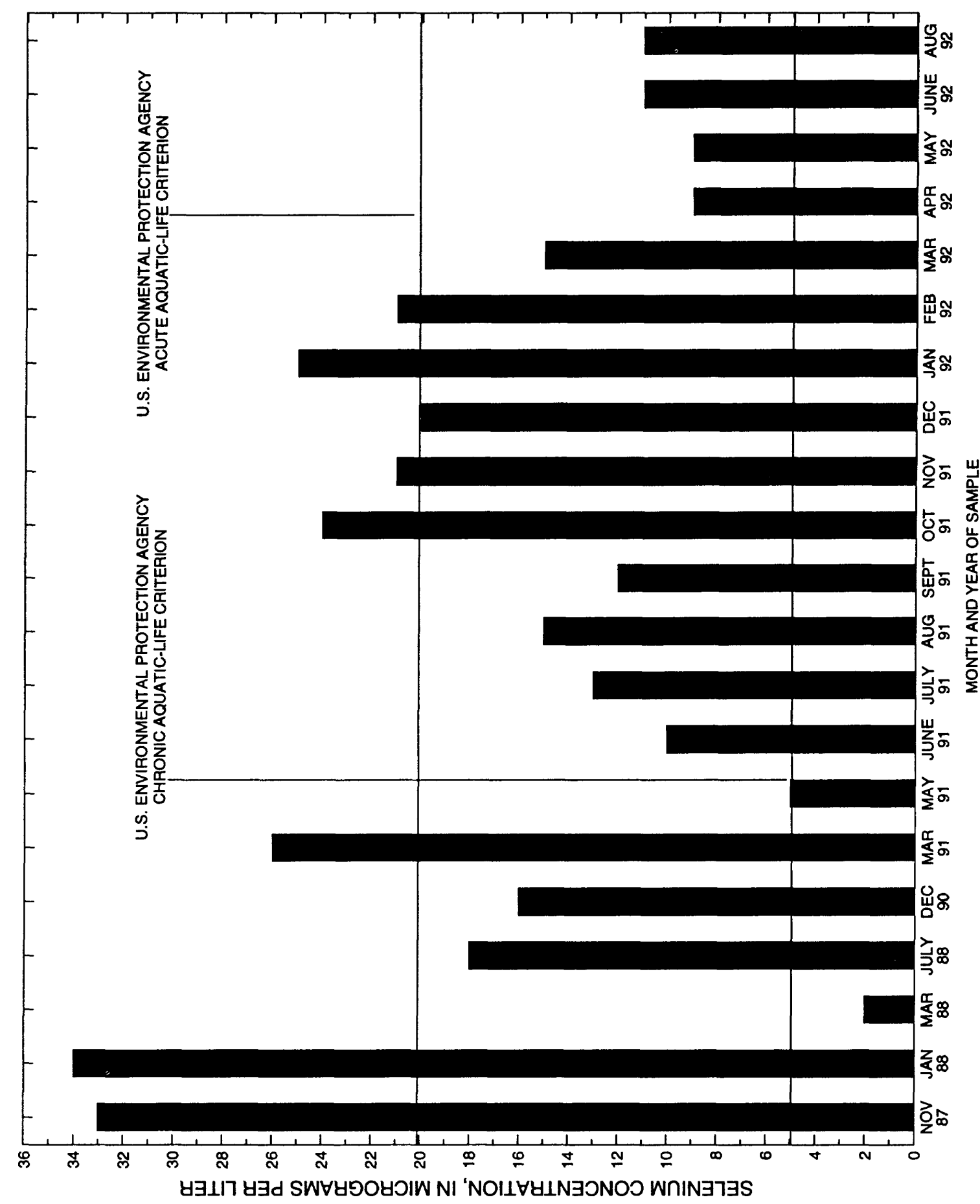

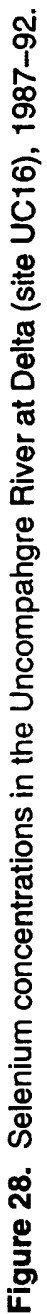




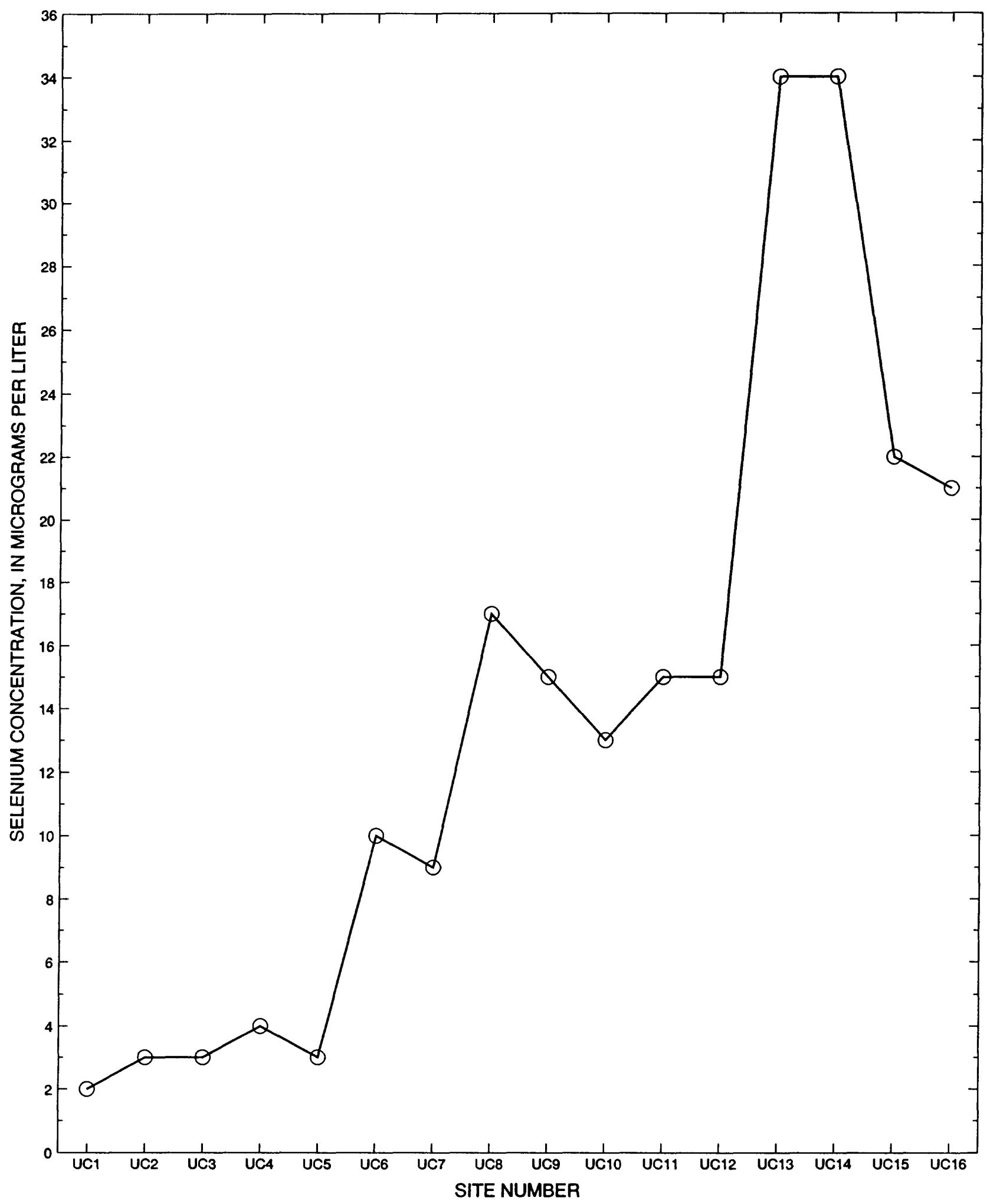

Figure 29. Selenium concentrations in the Uncompahgre River, February 19-20, 1992. 
Selenium concentrations in about 84 percent of the samples collected during the irrigation season exceeded the chronic criterion. Surface-water samples (excluding ponds) collected in the Grand Valley during the nonirrigation season probably are representative of irrigation-drainage discharge. Three water samples collected in June 1991 and 1992 from ponds RDP and MWP (fig. 30) had selenium concentrations equal to the chronic criterion of $5 \mu \mathrm{g} / \mathrm{L}$.

Selenium concentrations were much higher in irrigation drainage than in the irrigation-supply water from the Colorado River or in water at reference sites, which are upstream from the irrigated area. The median selenium concentration was $1 \mu \mathrm{g} / \mathrm{L}$ in water samples from site COL2 on the Colorado River (table 15) upstream from the Grand Valley. Selenium concentrations ranged from 1 to $6 \mu \mathrm{g} / \mathrm{L}$ in five samples from reference sites on West Salt Creek (site WSC2), East Salt Creek (site ESC3), and Big Salt Wash (site BSW3) (site locations in fig. 30).

Table 18. Summary of selenium concentrations in irrigated areas in the Grand Valley and the number of samples that exceeded aquatic-life criteria of the U.S. Environmental Protection Agency

[Concentrations in micrograms per liter; irrigation-season samples collected in August through October 1991 and April through August 1992; nonirrigation-season samples collected in March 1991 and from November 1991 through March 1992; chronic aquatic-life criterion is 5 micrograms per liter, and the acute criterion is $\mathbf{2 0}$ micrograms per liter (U.S. Environmental Protection Agency, 1987); <, less than]

\begin{tabular}{lccccc}
\hline Season & $\begin{array}{c}\text { Number of } \\
\text { sampies }\end{array}$ & Median Range & \multicolumn{2}{c}{$\begin{array}{c}\text { Number of } \\
\text { samples } \\
\text { exceeding } \\
\text { criteria }\end{array}$} \\
\cline { 3 - 7 } & 44 & 10 & $<1-58$ & 37 & 7 \\
Irrigation & 76 & 50 & $1-380$ & 73 & 62 \\
\hline
\end{tabular}

There are large differences in selenium concentrations between adjacent drainage basins in the Grand Valley. A comparison of the mean selenium concentrations in samples collected in March 1991 and in February and March 1992 for the 20 reconnaissance sites is shown in figure 32. Relative locations of the 20 sites are shown in figures 30 and 31 . Some of the highest selenium concentrations were at outflow sites in some of the larger drainage basins within the irrigated area, such as sites SC (Salt Creek), site RW1 (Reed Wash), and site LC1 (Leach Creek). Larger streams also tended to have the largest stream discharges for the 20 reconnaissance sites.
The median concentration of the samples collected in March 1991 at the 20 sites was $28.5 \mu \mathrm{g} / \mathrm{L}$, but the discharge-weighted mean concentration was $77 \mu \mathrm{g} / \mathrm{L}$; for the samples collected in February and March 1992, the median concentration was $36.5 \mu \mathrm{g} / \mathrm{L}$, but the discharge-weighted mean concentration was $74 \mu \mathrm{g} / \mathrm{L}$.

The selenium concentrations in samples collected for synoptic surveys in February and March 1992 indicate a highly variable distribution of selenium concentrations in irrigation drainage in the Grand Valley. For the synoptic surveys of the Grand Valley in 1992, 44 sites were sampled, including the 20 reconnaissance sites that were sampled in 1991.

The synoptic-survey data are shown in figures $\mathbf{3 0}$ and 31 and are summarized by geographical areas in table 19. The synoptic data are assumed to represent selenium concentrations in irrigation drainage in the Grand Valley. The synoptic samples were collected when natural runoff was nonexistent or minimal, and there were no diversions for winter water. On an areal basis, the highest median selenium concentrations in the Grand Valley were in the Salt Creek and Reed Wash Basins, which drain the western part of the irrigated area (fig. 30, table 19). The lowest median selenium concentrations were for the Redlands and Orchard Mesa areas (table 19). The Redlands area and Orchard Mesa are on terrace deposits overlying Mancos Shale, and there would be less selenium in the terrace deposits.

The synoptic-survey data indicated variable selenium concentrations within some of the major tributary basins. In the Salt Creek Basin, selenium concentrations in East Salt Creek (site ESC1) were more than twice as high as in West Salt Creek (site WSC1) or in Mack Wash (site MW1) (fig. 30). Water samples from the outflow site on Reed Wash (site RW1) represented mixtures of irrigation drainage in the Reed Wash Basin that had variable selenium concentrations. The selenium concentration of $260 \mu \mathrm{g} / \mathrm{L}$ for the East Branch of Reed Wash (site RWEB) was much higher than concentrations in Peck and Beede Wash (site RWPB) or in an unnamed tributary at site RWTR (fig. 30). The maximum selenium concentration reported in a Grand Valley surface-water sample was $380 \mu \mathrm{g} / \mathrm{L}$ in the sample collected in the nonirrigation season at site RW4 on upper Reed Wash. Site RW4 also had the largest selenium concentration of irrigation-season samples. However, the stream discharge at site RW4 was less than 1 percent of the stream discharge in Reed Wash at site RW1. 


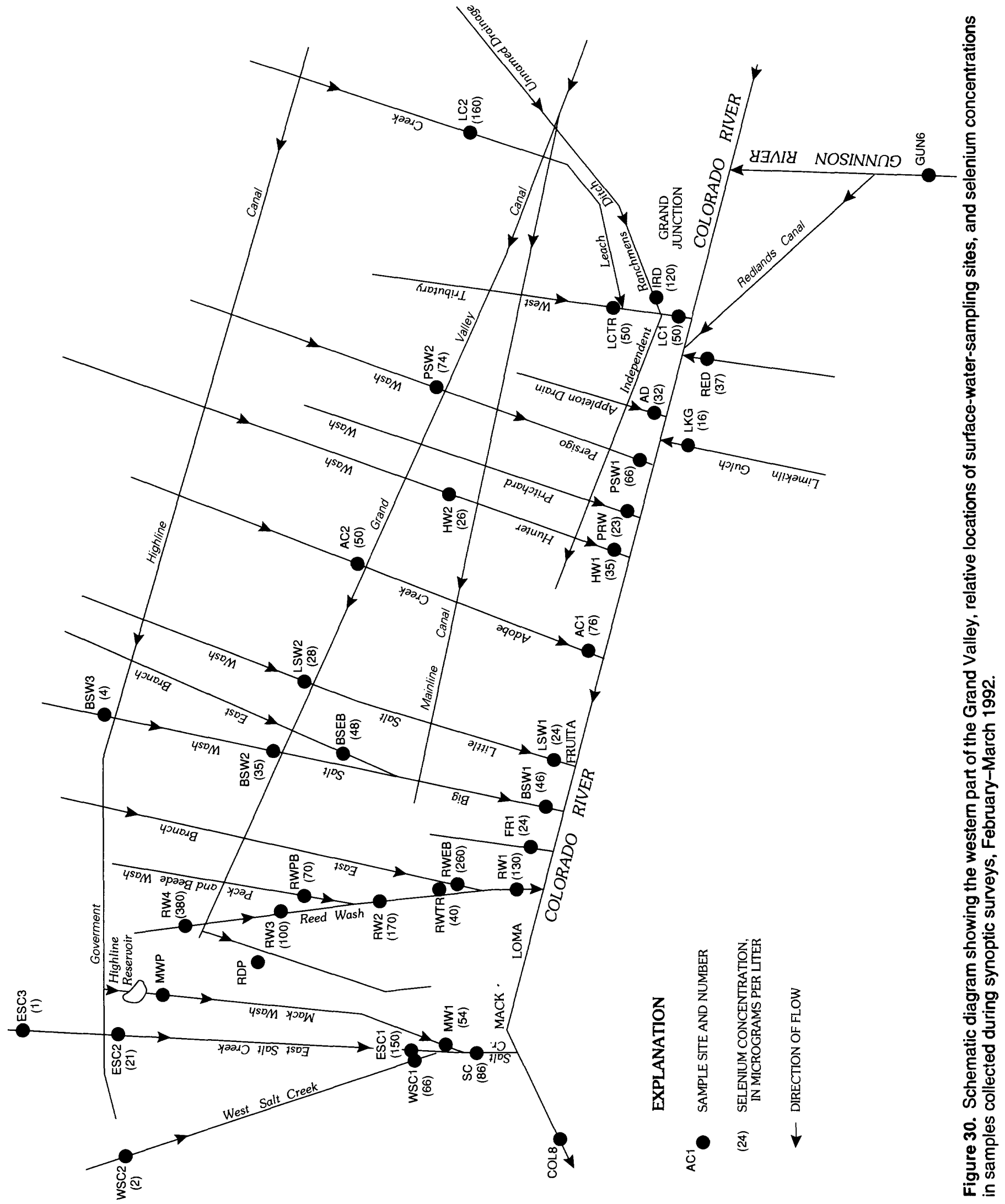




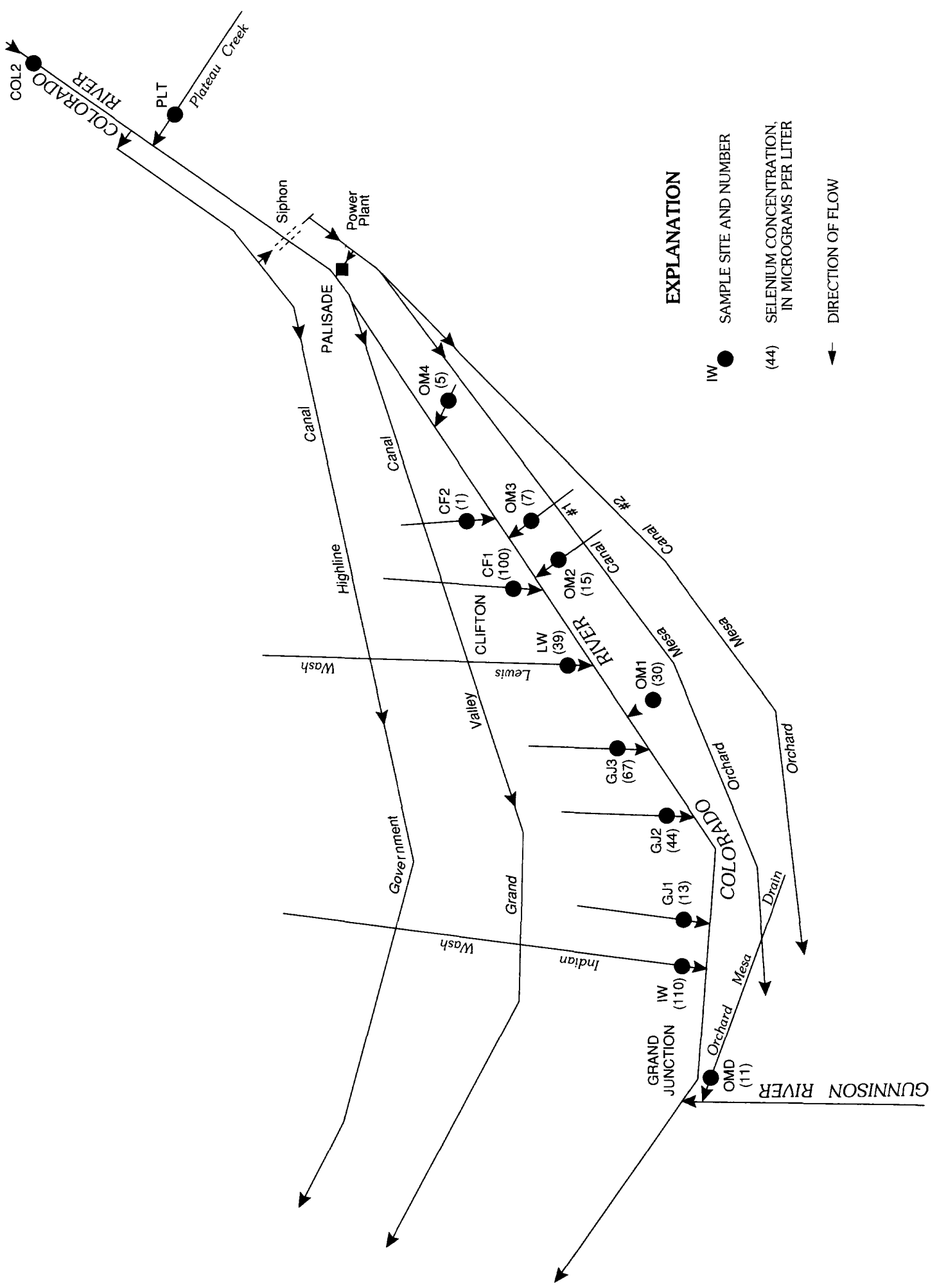

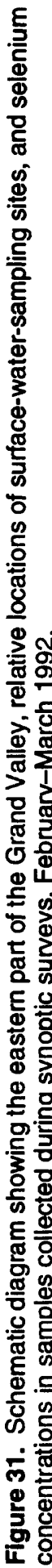




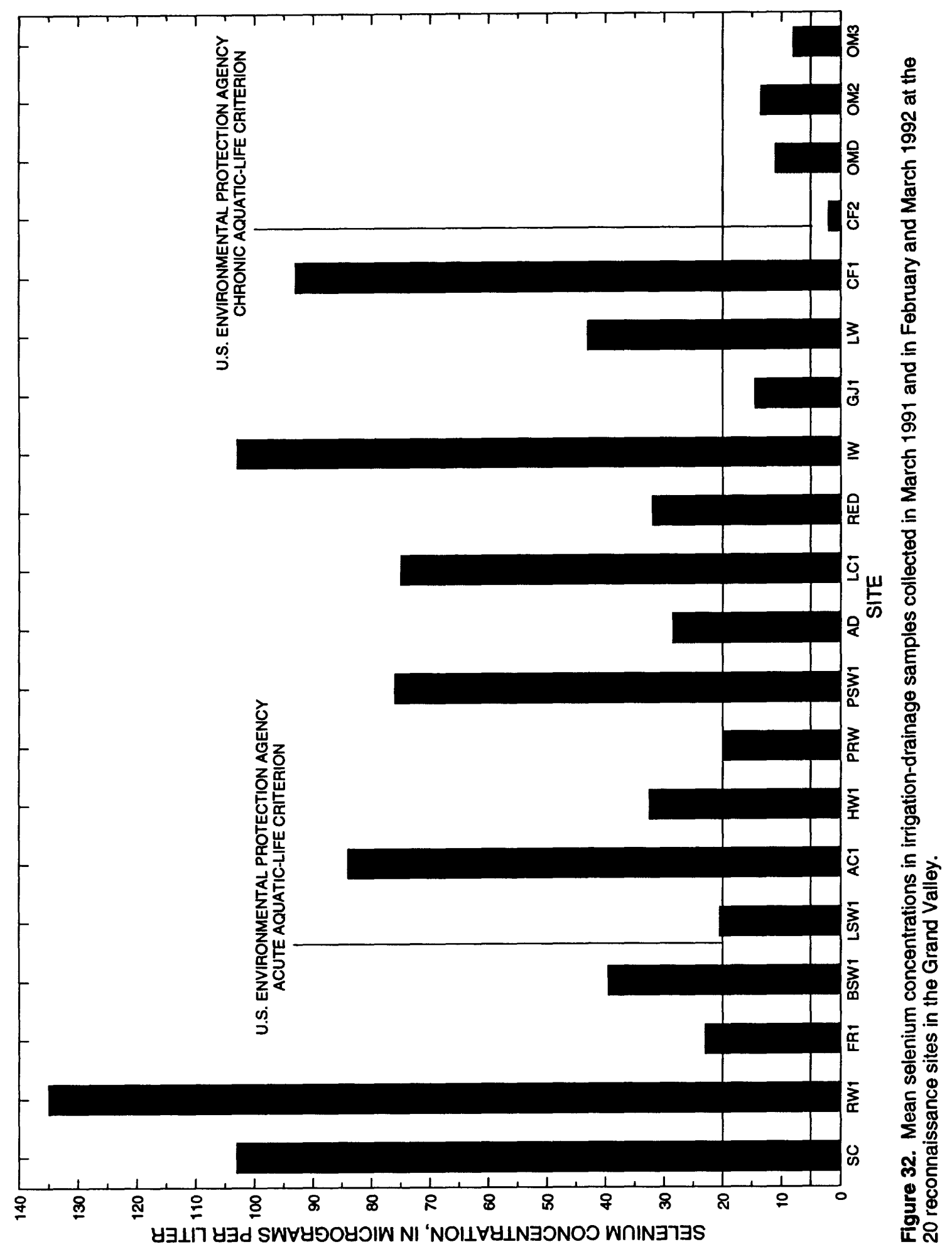


Table 19. Summary of selenium concentrations in samples collected during the synoptic surveys of the Grand Valley, February and March 1992

[Concentrations in micrograms per liter; reference sites not included]

\begin{tabular}{|c|c|c|c|c|}
\hline $\begin{array}{l}\text { Drainage basin } \\
\text { or area }\end{array}$ & $\begin{array}{l}\text { Number } \\
\text { of sites }\end{array}$ & $\begin{array}{l}\text { Sites inciuded } \\
\text { (figs. } 30 \text { and } 31 \text { ) }\end{array}$ & Median & Range \\
\hline Salt Creek and Reed Wash Basins & 12 & $\begin{array}{l}\text { WSC1, ESC1, ESC2, SC, MW1, RW1-RW4, RWTR, } \\
\text { RWPB, RWEB }\end{array}$ & 115 & $21-380$ \\
\hline $\begin{array}{l}\text { Big Salt and Little Salt Wash Basins } \\
\text { and miscellaneous ditches }\end{array}$ & 6 & FR1, BSW1, BSW2, BSEB, LSW1, LSW2 & 31.5 & $24-48$ \\
\hline $\begin{array}{l}\text { Area west of Grand Junction and } \\
\text { east of Fruita }\end{array}$ & 12 & $\begin{array}{l}\text { ACl, AC2, HW1, HW2, PRW, PSW1, PSW2, AD, } \\
\text { LC1, LC2, LCTR, IRD }\end{array}$ & 50 & $23-160$ \\
\hline Redlands area & 2 & RED, LKG & 26.5 & $16-37$ \\
\hline Area east of Grand Junction to Clifton area & 7 & IW, GJ1-GJ3, LW, CF1, CF2 & 44 & $1-110$ \\
\hline Orchard Mesa area & 5 & OMD, OM1-OM4 & 11 & $5-30$ \\
\hline
\end{tabular}

Another area of apparently higher selenium concentrations in the Grand Valley is drained by upper Leach Creek (site LC2) and by an unnamed wash (fig. 30) adjacent to the Leach Creek Basin. The unnamed wash becomes the Independent Ranchmens Ditch where the wash intersects the Grand Valley Canal, and the ditch discharges into Leach Creek at site IRD (fig. 30). Much of the eastern part of the Leach Creek Basin and the area drained by the unnamed wash are residential and commercial areas. Samples also were collected at multiple sites in several other drainage basins in the western part of the Grand Valley, but large differences among selenium concentrations were not apparent (fig. 30).

Selenium concentrations were variable in the sampled washes and ditches between Grand Junction and the Clifton area (fig. 31). Selenium concentrations in Indian Wash (site IW) were considerably higher than the concentrations in three unnamed drainage ditches (sites GJ1, GJ2, and GJ3 in fig. 31). Site CF2, on an unnamed drainage ditch east of Clifton, had the lowest selenium concentrations in surfacewater samples from irrigated areas in the Grand Valley; however, selenium concentrations were much higher in another unnamed drainage ditch at site CF1, which is located about 2 mi southwest of site CF2 (fig. 31).
Selenium concentrations were much lower in irrigation-season samples compared to the nonirrigation-season samples in the Grand Valley; these seasonal differences were similar to the seasonal differences in selenium concentrations for surface water on the eastern side of the Uncompahgre Project. Seasonal distribution of selenium concentrations are shown for three frequently sampled sites in the Grand Valley in figure 33. Large quantities of surface-return flow from canals, laterals, ditches, and field runoff are discharged into streams and washes during the irrigation season, which dilute selenium concentrations in irrigation-drainage water. Historical stream-discharge data for discontinued gaging stations on eight streams and washes in the Grand Valley (data collected in water years 1973-83) indicated that 86 to 95 percent of the annual stream discharge occurred during the irrigation season (April through October). The median selenium concentration for the irrigationseason samples collected from August 27 to September 4, 1991, at the 20 reconnaissance sites was $8.5 \mu \mathrm{g} / \mathrm{L}$, compared to $28.5 \mu \mathrm{g} / \mathrm{L}$ for nonirrigationseason samples collected in March 1991 and $36.5 \mu \mathrm{g} / \mathrm{L}$ for nonirrigation-season samples collected in February 1992 at the same 20 sites. Despite dilution during the irrigation season, selenium concentrations in most surface-water samples collected during the irrigation season in the Grand Valley exceeded the chronic aquatic-life criterion (table 18). Four of the eight samples collected at site RW1 on 
Reed Wash (fig. 33) during the irrigation season exceeded the acute aquatic-life criterion of $20 \mu \mathrm{g} / \mathrm{L}$ (U.S. Environmental Protection Agency, 1987).

At least 96 percent of the dissolved selenium in samples collected on March 24, 1992, from five streams in the Grand Valley was selenate (table 20). Selenate is the most soluble form of selenium and is stable in alkaline and oxygenated conditions (Presser and others, 1990). Field measurements of $\mathrm{pH}$ were greater than 7.5, and dissolved oxygen usually was near saturation in all water samples from streams, washes, and ditches in the Grand Valley. The selenium-speciation results infer that once selenium is discharged by ground water (irrigation drainage) into the oxygenated environment of the streams, selenium remains in solution as selenate and is transported out of the irrigated areas into the Colorado River. The selenate and selenite data for the five Grand Valley tributaries were used for riskassessment analysis for endangered fish (described later in the report in the "Risk Assessment for Endangered Fish from Selenate and Selenite" section).

\section{Magnitude and Variation of Selenium loads}

The magnitude and variation of selenium loads in irrigated areas of the Uncompahgre Project and in the Grand Valley are discussed in this section.

Selenium-load data are used to describe major source areas of selenium from the irrigated areas.

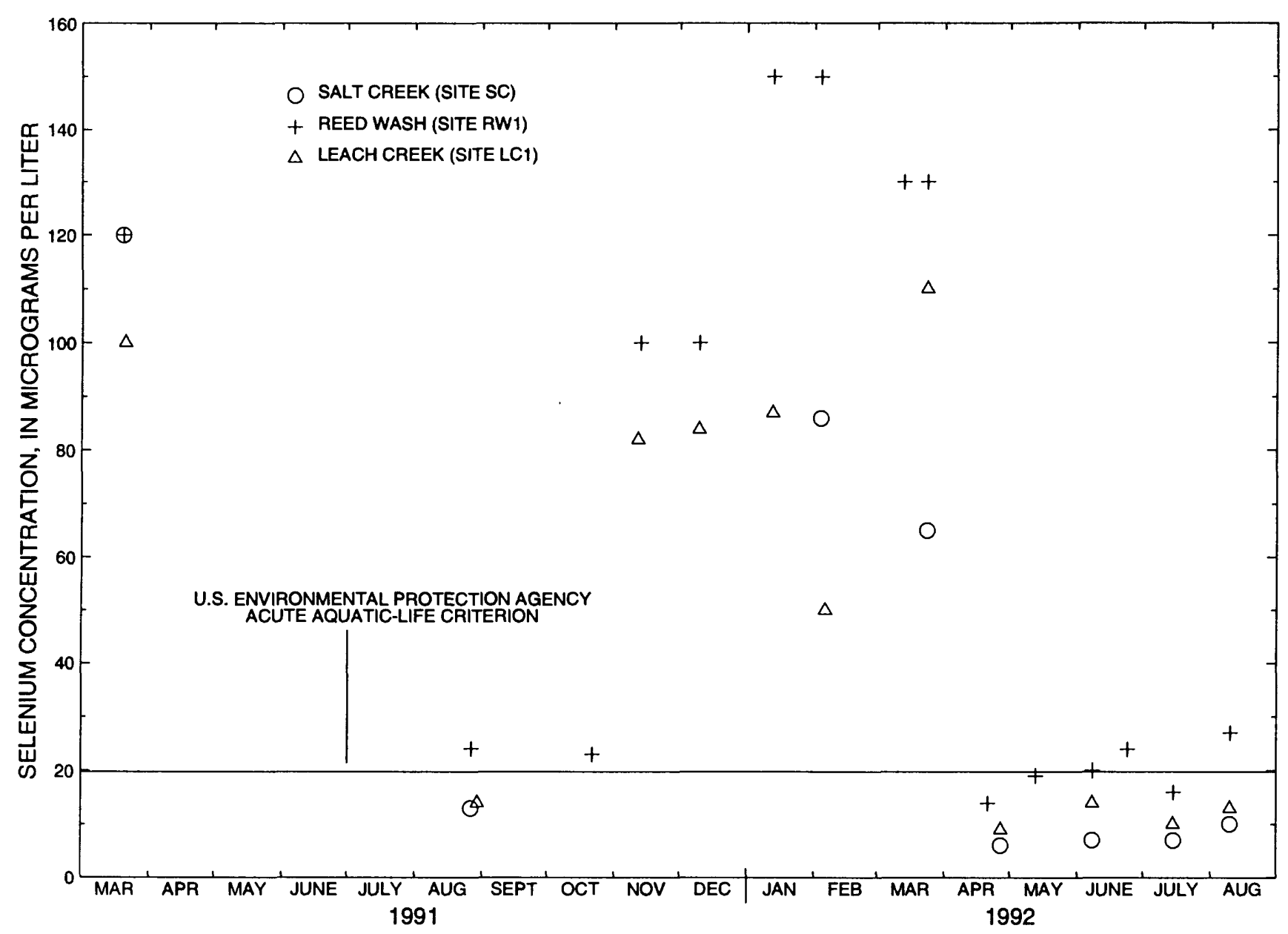

Figure 33. Selenium concentrations in samples from Salt Creek at site SC, Reed Wash at site RW1, and Leach Creek at site LC1, March 1991-August 1992. 
Table 20. Concentrations of dissolved selenium, selenate, and selenite in water samples collected from five streams in the Grand Valley, March 24, 1992

[Concentrations in micrograms per liter; data from Roger Fujii (U.S. Geological Survey, written commun., 1992); sites shown in figs. 30 and 31]

\begin{tabular}{clcccr}
\hline $\begin{array}{c}\text { Site } \\
\text { number }\end{array}$ & $\begin{array}{c}\text { Stream } \\
\text { name }\end{array}$ & $\begin{array}{c}\text { Dissolved } \\
\text { selenium }\end{array}$ & $\begin{array}{c}\text { Selenate } \\
\text { selenlum }\end{array}$ & $\begin{array}{c}\text { Selenite } \\
\text { selenium }\end{array}$ & $\begin{array}{c}\text { Percent } \\
\text { selenate }\end{array}$ \\
\hline SC & Salt Creek & 72.8 & 71.7 & 1.1 & 98.5 \\
RW1 & Reed Wash & 126.2 & 126.2 & 0 & 100.0 \\
AC1 & Adobe Creek & 74.8 & 72.5 & 2.3 & 96.9 \\
LC1 & Leach Creek & 85.6 & 83.4 & 2.2 & 97.4 \\
IW & Indian Wash & 86.1 & 82.8 & 3.3 & 96.2 \\
\hline
\end{tabular}

\section{Uncompahgre Project Area}

The gain-loss study of the Uncompahgre River on February 19-20, 1992, indicated that the selenium load increased $13.4 \mathrm{lb} / \mathrm{d}$ between Colona (site UC1) and Delta (site UC16), which was 96 percent of the load at Delta (fig. 34). Relative locations of the sampling sites on the Uncompahgre River and on tributaries are shown in figures 25 and 26. The actual gain in selenium load probably was greater than $13.4 \mathrm{lb} / \mathrm{d}$ because some of the selenium load in winter water that was diverted from the Uncompahgre River was not measured at site UC16. Winter water is lost by consumptive use, canal and lateral seepage, and part of the unused winter water was discharged into the Gunnison River between Cummings Gulch and Roubideau Creek (fig. 26). Winter-water diversions were made upstream from site UC2 (West Canal) and immediately downstream from site UC3 (Montrose and Delta Canal), site UC7 (Selig Canal), and site UC9 (Ironstone Canal).

Much of the increase in selenium load in the Uncompahgre River between Colona and Delta occurred in 4 of the 15 sampled reaches. Much of the gain in selenium load in reach UC5-UC6 (fig. 34) is from Dry Cedar Creek (site DCC1 in fig. 25), which accounted for about 50 percent of the load at UC6. Cedar Creek (site CD1) accounted for about 93 percent of the increase in selenium load between sites UC7 and UC8 and for about 74 percent of the selenium load at site UC8. The largest increase in selenium load occurred in the reach between sites UC12 and UC13. Loutsenhizer Arroyo (site LZAM in fig. 26) discharges into the
Uncompahgre River between sites UC12 and UC13, and the load at site LZAM was $1.7 \mathrm{lb} / \mathrm{d}$ greater than the difference in loads between sites UC13 and UC12. That difference could result from errors in discharge measurements or in the selenium analyses. Loutsenhizer Arroyo accounted for about 90 percent of the gain in dissolved-solids load in reach UC12-UC13; a reasonable assumption is that at least 90 percent of the gain in selenium load in reach UC12-UC13 was from Loutsenhizer Arroyo. The selenium load from Dry Creek (site DRY1) accounts for much of the gain in reach UC14-UC15. Some of the selenium load in Dry Creek in February 1992 was from return flow of winter water that was discharged from the Ironstone Canal and its laterals.

Selenium loading into other reaches of the Uncompahgre River were relatively small. Stream reaches that had a decrease in selenium load (fig. 34) either lost water to alluvium or had winter-water diversions. Based on mass-balance calculations for reaches where selenium loads increased, unaccounted inflow of water containing higher selenium concentrations might be discharging into reaches UC8-UC9, UC10-UC11, and UC13-UC14. The selenium concentrations computed by massbalance differences ranged from 23 to $52 \mu \mathrm{g} / \mathrm{L}$ in unaccounted inflows for these three reaches. Those concentrations were higher than selenium concentrations in winter water, which infers that part of the gain of selenium load in the three reaches was from ground-water discharge into the Uncompahgre River and not from return flow of winter water. 


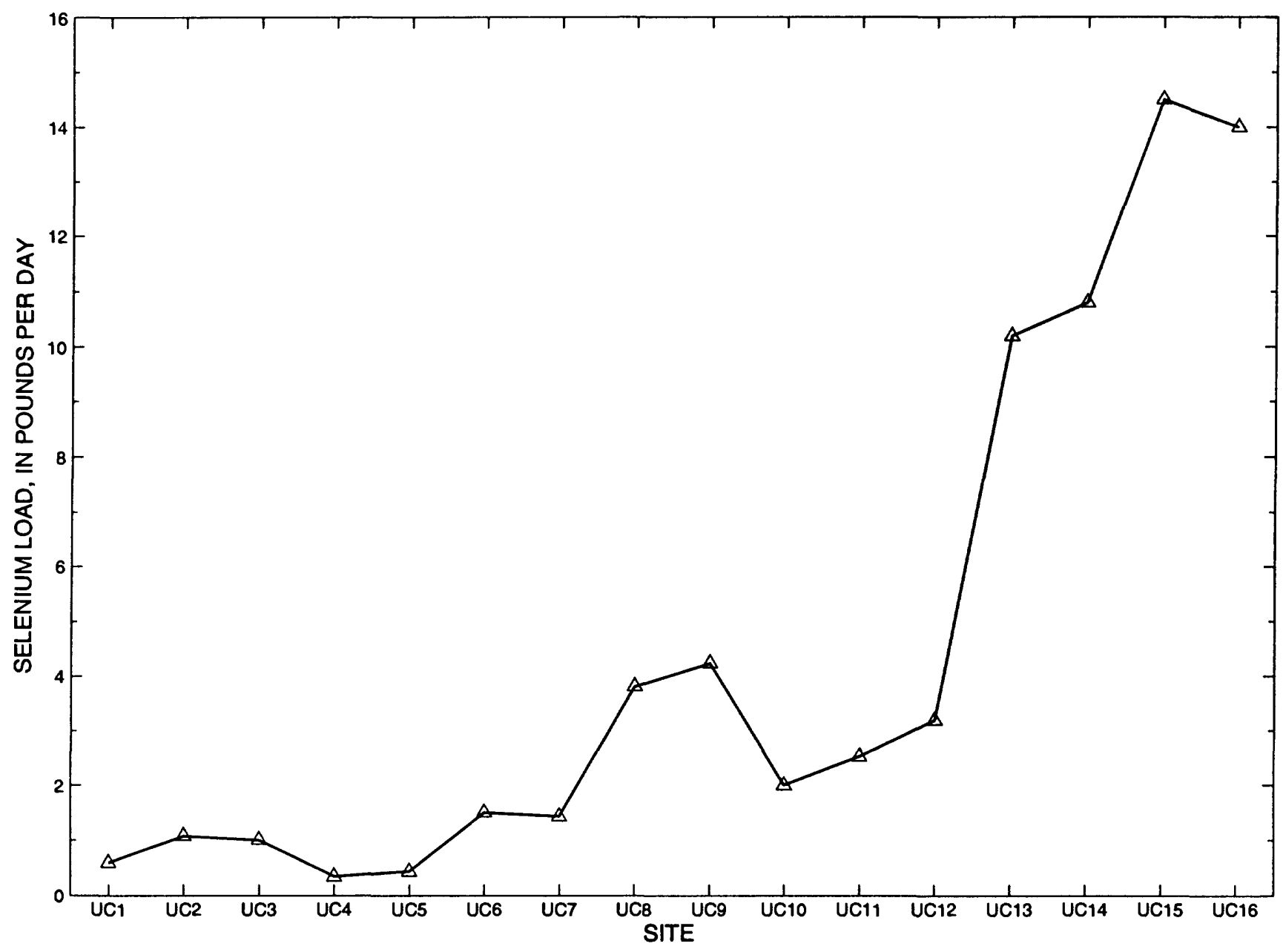

Figure 34. Selenium loads in the Uncompahgre River, February 19-20, 1992.

The mean selenium load in the Uncompahgre River at site UC16 for 20 samples collected in water years 1991-92 was $18.7 \mathrm{lb} / \mathrm{d}$. A seasonally weighted mean was computed by weighting the mean selenium load for irrigation-season samples (April through October) and the mean load for the nonirrigation-season samples (November through March) according to the fraction of the year that each season composes ( 0.59 for irrigation, 0.41 for nonirrigation). The seasonally weighted mean selenium load was equal to the mean selenium load for the Uncompahgre River at site UC16 (water years 1991-92), which indicates that there were no large differences in selenium loads between the irrigation season and nonirrigation season in the Uncompahgre River.
The largest selenium loads in tributary streams are on the eastern side of the Uncompahgre Project, and the largest seasonally weighted mean selenium load was $14.0 \mathrm{lb} / \mathrm{d}$ for Loutsenhizer Arroyo at site LZA1. The seasonally weighted mean selenium loads for all samples collected at outflow sites on 12 tributary streams or canals draining the Uncompahgre Project are shown in figure 35. Because of canal diversions on the Uncompahgre River, part of the selenium load discharging from the Dry Cedar and Cedar Creek Basins on the eastern side of the project is rediverted into canals near or downstream from Montrose (figs. 25 and 26). The rediversion of considerable quantities of surface-return flow and irrigation drainage from the Uncompahgre River for 
irrigation-supply water complicates the determination of the total-selenium load from the Uncompahgre Project. Perhaps a more accurate measure of selenium load from the project would be to determine selenium loads in all streams, canals, and ditches that discharge into the southern side of the Gunnison River between Peach Valley Arroyo and Roubideau Creek.

Water from Loutsenhizer Arroyo is used to supplement the water supply for the Garnet Canal; therefore, some of the selenium load from the arroyo is redistributed by the Garnet Canal system into areas east of Delta. The diversion structure on the arroyo is between site LZA1 and the Uncompahgre River. The fraction of the selenium load in the Garnet Canal that came from Loutsenhizer Arroyo was not determined. A small fraction of the annual flow of the Garnet Canal is diverted into Sweitzer Lake; therefore, a small fraction of the selenium load from
Loutsenhizer Arroyo might eventually be incorporated into Sweitzer Lake bottom sediment through chemical and biological processes. Tail water from the Garnet Canal discharges into the Relief Canal at site GAR4 (fig. 26), which discharges into the Bonafide Ditch. The Bonafide Ditch discharges into the Gunnison River immediately upstream from site GUN4 (figs. 23 and 26).

Much of the selenium load from the western side of the Uncompahgre Project apparently discharges from the northern part of the area, primarily from Dry Creek, Cummings Gulch, Seep Creek, and Roubideau Creek (fig. 26). Mass-balance calculations and synoptic-survey data indicate an unknown fraction of the selenium loads in those streams during the nonirrigation season of 1991-92 probably came from winter water transported by the Ironstone Canal and its laterals into these basins. It also is likely that

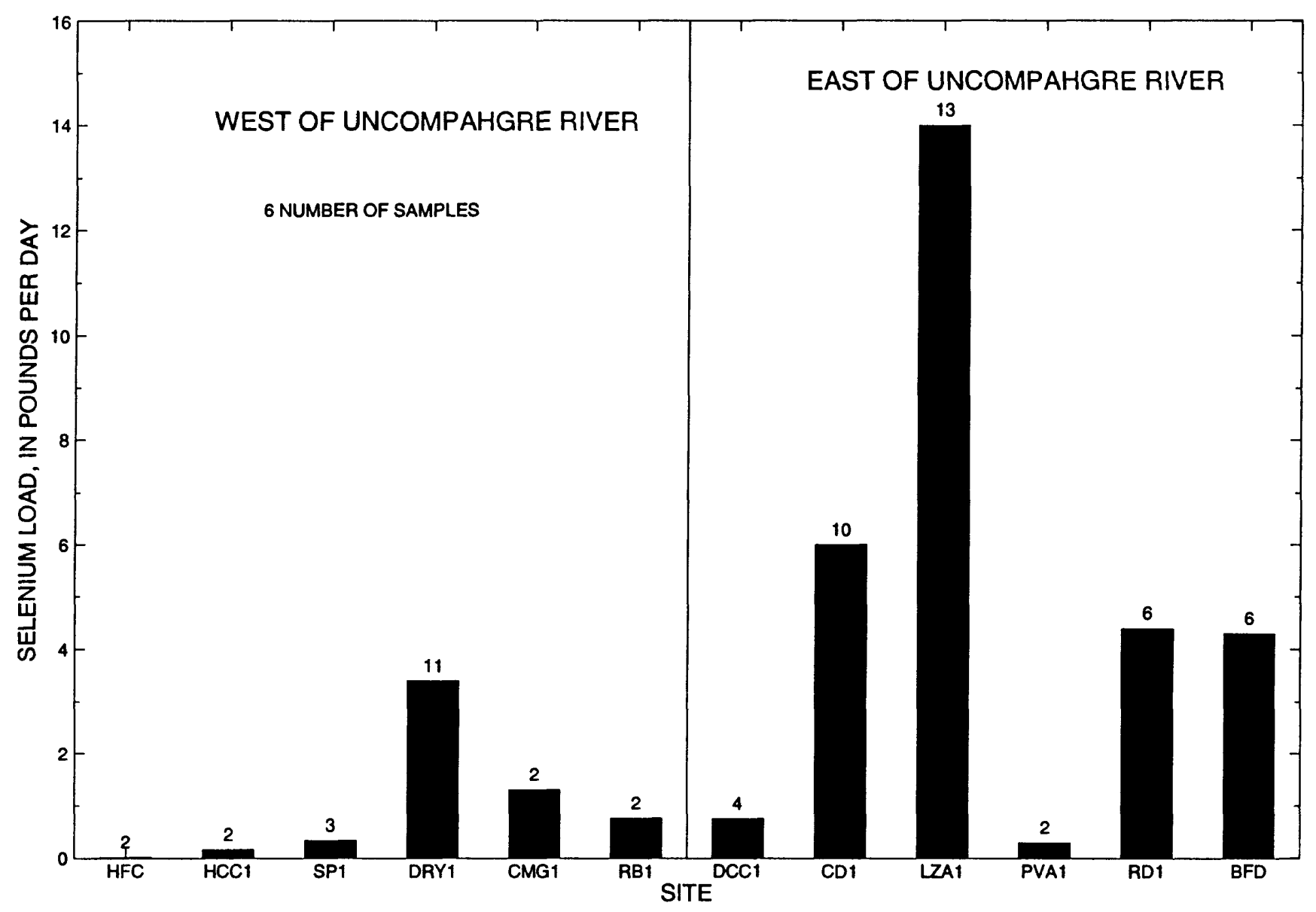

Figure 35. Seasonally weighted mean selenium loads for 12 sites in the Uncompahgre Project, 1991-92. 
irrigation-supply water from the Ironstone Canal is a source of selenium loading to the western side of the project during the irrigation season.

Selenium loads within major drainage basins on the eastern side of the Uncompahgre Project were variable based on the synoptic-survey data collected in 1992 and on data collected in water year 1993. For four sets of samples, about 35 to 42 percent of the selenium load discharging from Cedar Creek (at site CD1) was from Montrose Arroyo (fig. 25), although Montrose Arroyo accounted for less than 20 percent of the stream discharge in Cedar Creek. The unnamed west tributary of Loutsenhizer Arroyo (at site WLZ1 in fig. 26) accounted for about 40 percent of the stream discharge, but only about 20 percent of the selenium load in Loutsenhizer Arroyo at site LZA1 in March 1992. About 90 percent of the selenium load in the unnamed drainage near Read at site RD1 in March 1992 was discharged into the reach between sites RD2 and RD3 (fig. 26).

Selenium data collected during 1991-93 in the Cedar Creek and Loutsenhizer Arroyo Basins (figs. 25 and 26) indicate that some of the selenium load measured at outflow sites CD1 and LZA1 originated outside the irrigated area of the Uncompahgre Project. There are some areas that are irrigated with non-project water in both drainage basins that are upstream from the Uncompahgre Project. There are extensive areas of Mancos Shale in the upper Cedar Creek and Loutsenhizer Arroyo Basins. Irrigation drainage from the nonproject areas might contribute a small selenium load to Cedar Creek and Loutsenhizer Arroyo throughout the year. Natural runoff in the Cedar Creek and Loutsenhizer Arroyo Basins also might contribute to the selenium load in these streams. Natural runoff in Loutsenhizer Arroyo probably is limited to brief periods of snowmelt runoff in spring and runoff associated with heavy rainstorms. In addition to natural runoff associated with snowmelt and rain, there seems to be a small natural base-flow discharge into upper Cedar Creek. Three sets of samples were collected in March 1992 and March 1993 during periods of snowmelt runoff from Mancos Shale areas in the upper Cedar Creek and Loutsenhizer Arroyo Basins. For those samples, about 24 to 45 percent of the selenium load in Cedar Creek and about 13 to 36 percent of the selenium load in Loutsenhizer Arroyo were accounted for at the most upstream sampling site. Apparently, some of the selenium load measured at outflow sites on both streams was caused by snowmelt in the drainage basins upstream from the Uncompahgre Project. The selenium load resulting from snowmelt on Mancos Shale would be highly variable from year to year, depending on weather conditions. There was an accumulation of snow at low elevations in the Cedar Creek and Loutsenhizer Arroyo Basins in the winter of 1992. In some winters, snow accumulation at lower elevations in the Uncompahgre Project area is minimal, and the resulting snowmelt runoff from the Mancos Shale areas would be minimal.

The fraction of the selenium load in Cedar Creek and Loutsenhizer Arroyo from nonproject sources might be less in the irrigation season than in the nonirrigation season. Nonproject sources of selenium accounted for less than 5 percent of the selenium load in Loutsenhizer Arroyo and about 10 to 15 percent of the selenium load in Cedar Creek based on samples collected during the irrigation seasons in 1991 and 1993. During periods when the irrigationseason samples were collected, irrigation drainage from nonproject land probably was the sole source of selenium load to upper Loutsenhizer Arroyo, and non-project irrigation drainage and perhaps a small quantity of natural ground-water discharge were potential selenium sources to upper Cedar Creek.

The synoptic-survey results for March 1992 indicated that the Garnet Canal gained $1.1 \mathrm{lb} / \mathrm{d}$ of selenium between sites GAR1 and GAR2 (fig. 26). Most of the gain in selenium probably was from the drainage ditches at sites DR1 and DR2 (fig. 26) and from diffuse seepage of irrigation drainage into the canal. Essentially all the increase in selenium load in the Garnet Canal downstream from Sweitzer Lake (between sites GAR2 and GAR4) was from irrigationdrainage discharge from an unnamed natural drainage downstream from site UNGR (fig. 26). The selenium load discharged from the Garnet Canal (site GAR4 in fig. 26) accounted for almost all the selenium load in the Bonafide Ditch at site BFD in the samples collected on March 12, 1992.

Analysis of selenium loads for the more frequently sampled surface-water sites (the sites shown in fig. 35) indicated variable seasonal differences in mean selenium loads between irrigation and nonirrigation seasons. The mean selenium 
load for seven irrigation-season samples for Cedar Creek at site CD1 was $7.3 \mathrm{lb} / \mathrm{d}$, compared to the mean load of $4.1 \mathrm{lb} / \mathrm{d}$ for three nonirrigation-season samples. The mean selenium load of $14.7 \mathrm{lb} / \mathrm{d}$ for eight irrigation-season samples from Loutsenhizer Arroyo at site LZA1 is only slightly greater than the mean load of $13.0 \mathrm{lb} / \mathrm{d}$ for five nonirrigation-season samples. The seasonal differences between selenium loads for an unnamed drainage near Read at site RD1 and Dry Creek at site DRY1 were not large.

In July 1991, water samples were collected from the Gunnison River at sites GUN3 and GUN4 and from four tributaries draining irrigated areas adjacent to or upstream from the Uncompahgre Project

(fig. 23). The selenium load in the Gunnison River at site GUN3, which is upstream from all irrigation drainage from the Uncompahgre Project, was $5.6 \mathrm{lb} / \mathrm{d}$. About 50 percent of the load at site GUN3 was accounted for by the North Fork of the Gunnison River (site NFK1 in fig. 23). The sum of the selenium loads from the four other tributaries that drain nonproject irrigated areas (fig. 23)—the Smith Fork (site SMF), Currant Creek (site CRC), Alfalfa Run (site AFR), and Tongue Creek (site TGC)-was only $0.2 \mathrm{lb} / \mathrm{d}$ in July 1991 . When compared to selenium loading from streams draining the irrigated areas of the Uncompahgre Project, selenium loading from other drainage basins in the lower Gunnison River Basin were small. However, the basins outside the project were sampled only once, and the selenium loads might not be representative of the selenium loads throughout the year.

\section{Grand Valley}

The largest mean selenium loads in tributary streams draining the Grand Valley were for Salt Creek (site SC), Reed Wash (site RW1), Big Salt Wash (site BSW1), and Leach Creek (site LC1). Mean selenium loads for the 20 reconnaissance sites in the Grand Valley are compared in figure 36 . The loads shown in figure 36 are arithmetic means of the selenium loads for the three sets of samples collected in March 1991, in late summer of 1991, and in February or March 1992. The greatest mean selenium load shown in figure 36 is $11.2 \mathrm{lb} / \mathrm{d}$ for site RW1; however, the seasonally weighted mean selenium load for site RW1, based on the 15 samples collected during $199 \mathrm{l}-92$, was $12.8 \mathrm{lb} / \mathrm{d}$. The selenium loads for the 20 sites might represent much of the selenium load discharging from tributary streams into the Colorado River. However, the selenium loads from numerous, small washes and drainage ditches were not measured. There probably is discharge of irrigation drainage directly into the Colorado River in ground water that is not intercepted by tributary streams, washes, and drainage ditches. Ground-water studies by BOR (1986a) indicate that the cobble aquifer discharges directly into the Colorado River in the Fruita area. The cobble aquifer probably is of sufficient depth in many areas in the Grand Valley so that surface streams and drainage ditches might not intercept appreciable quantities of water from the cobble aquifer

Most of the irrigation-induced selenium load from the Grand Valley is from irrigated areas west of the Gunnison River and north of the Colorado River. Ninety-three percent of the sum $(33.3 \mathrm{lb} / \mathrm{d})$ of the mean selenium loads for the 20 sites shown in figure 36 was accounted for in the drainage basins in the western part of the Grand Valley between Salt Creek and Leach Creek (fig. 3). About 70 percent of the irrigated land in the Grand Valley is west of Grand Junction and north of the Colorado River (Bureau of Reclamation, 1986b). Most of the irrigated land in the western part of the Grand Valley is on soils derived from alluvium on Mancos Shale or shale residuum.

Selenium loads for sites on the Redlands area, the area east of the Gunnison River and north of the Colorado River, and on Orchard Mesa generally were smaller than loads in the streams and washes west of Grand Junction (figs. 30, 31, and 36). Except for Indian Wash and an unnamed drainage near Clifton at site $\mathrm{CF} 1$, selenium loads in washes and ditches in those areas generally ranged from 0.01 to $0.20 \mathrm{lb} / \mathrm{d}$ (fig. 36). One reason for smaller selenium loads in these areas is that the washes and drainage ditches have small drainage-basin areas, and subsequently the stream discharges are smaller compared to stream discharges in larger basins. The Redlands and Orchard Mesa areas primarily are on terrace deposits. Soils derived from terrace deposits should contain less material derived from the Mancos Shale, and consequently, irrigation drainage from terrace deposits generally had lower selenium concentrations compared to other areas in the Grand Valley (table 19). The Redlands area accounts for about 6 percent, the area east of Grand Junction to 


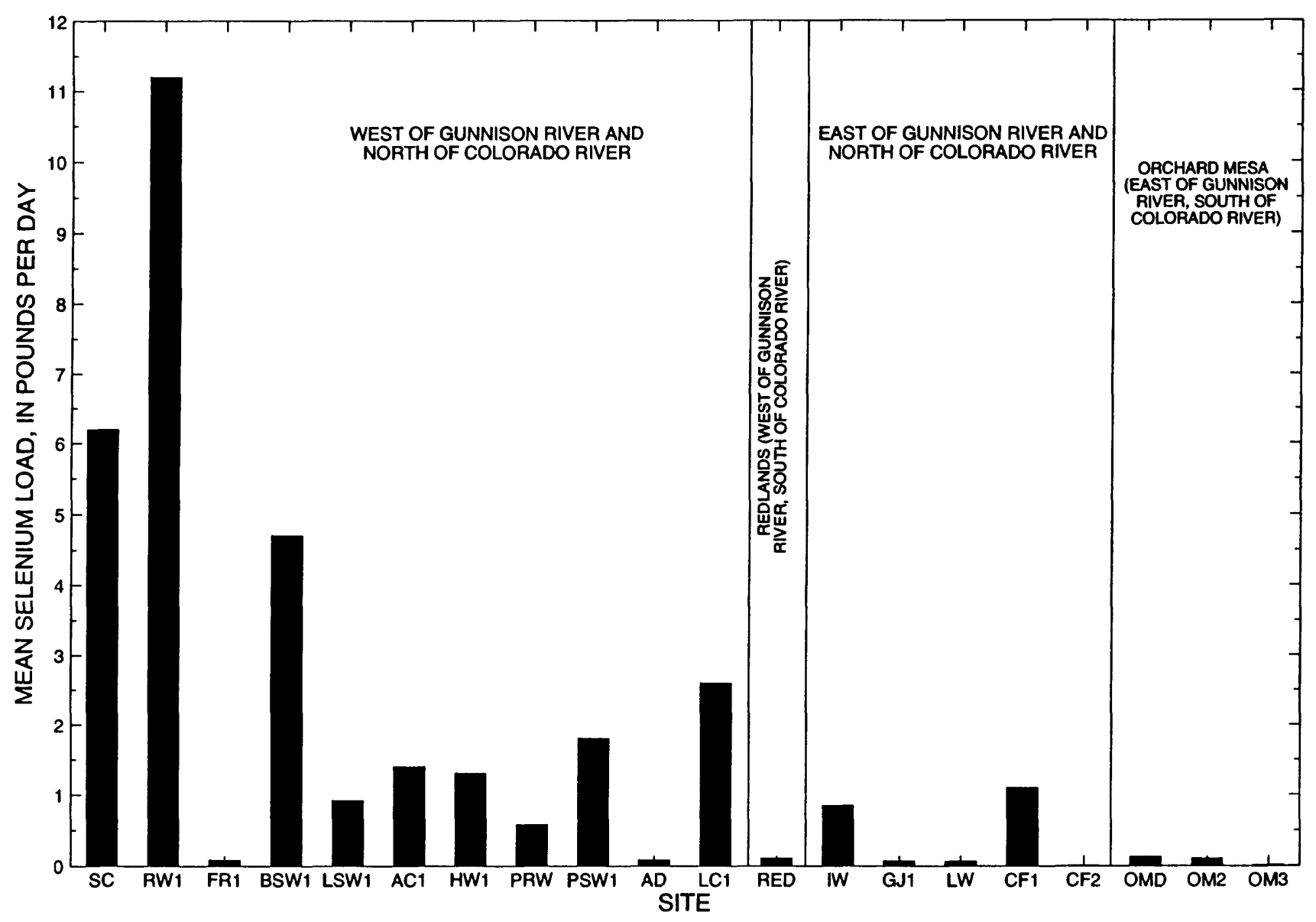

Figure 36. Mean selenium loads of three sets of samples collected in 1991-92 for 20 sites in the Grand Valley.

the east end of the valley (north of the Colorado River) accounts for about 16 percent, and Orchard Mesa about 11 percent of the irrigated area in the Grand Valley. Large sections of the Redlands, the area between Grand Junction and Clifton, and western Orchard Mesa are residential and commercial areas.

The synoptic data collected during the nonirrigation season in early 1992 were used to examine selenium-loading differences within the major streams that drain the Grand Valley. In Reed Wash in March 1992, about one-half the selenium load at the outflow site (RW1 in fig. 30) was from the East Branch (site RWEB). Surveys on Big Salt Wash, Little Salt Wash, Adobe Creek, Hunter Wash, and Persigo Wash (fig. 30) indicated that 67 to 81 percent of the selenium load at the outflow sites was gained in the lower reaches of the streams. Much of the increase in selenium loads in those five streams was caused by increases in stream discharge rather than by downstream increases in selenium concentrations.

Selenium loads in some streams and drains in the Grand Valley were higher in the irrigation season (April through October) than in the nonirrigation season (November through March). For the 20 reconnaissance sites (fig. 36), the sum of selenium loads for the samples collected March 20-22, 1991, was $18.0 \mathrm{lb} / \mathrm{d}$, compared to $60.0 \mathrm{lb} / \mathrm{d}$ for samples collected August 27-September 4, 1991, at the same sites. Four sites were sampled at least five times, and the selenium loads for each sample are shown in figure 37. For Reed Wash at site RW1, the mean selenium load for irrigation-season samples $(16.6 \mathrm{lb} / \mathrm{d})$ is more than twice the mean load of nonirrigation-season samples $(7.5 \mathrm{lb} / \mathrm{d})$. Greater irrigation-season selenium loads also were indicated for Salt Creek (site SC) and Big Salt Wash 
(site BSW1) (fig. 37). By contrast, the mean selenium load for irrigation-season samples for Leach Creek at site $\mathrm{LC1}$ was about 25 percent less than the mean load for the nonirrigation-season samples.

During the nonirrigation season, irrigation drainage from the Independent Ranchmens Ditch is discharged into Leach Creek at site IRD. During the irrigation season, most of the water in the Independent Ranchmens Ditch flows in a pipe over Leach Creek to irrigate fields west of Leach Creek. Therefore, most of the selenium load in the Independent Ranchmens Ditch was not discharged into Leach Creek during the irrigation season.

Although the discharges in Grand Valley streams and washes are much higher in the irrigation season than in the nonirrigation season, the increase in discharge does not account for all of the increase in selenium loads during the irrigation season. The range of stream-discharge measurements for the 15 water samples collected from Reed Wash at site RW1 was 7.0 to $168 \mathrm{ft}^{3} / \mathrm{s}$, and the range for 8 samples from Salt Creek at site SC was 7.1 to $203 \mathrm{ft}^{3} / \mathrm{s}$. In the Grand Valley, a large quantity of unused irrigation water is discharged from canals and laterals into the washes during the irrigation season. However, selenium concentrations in the irrigation-supply water are too small to be the sole cause of higher selenium loads in streams and washes during the irrigation season. In drainage basins, such as Reed Wash, either groundwater (irrigation-drainage) discharge had to increase or selenium concentrations in ground water had to increase to account for the higher selenium loads

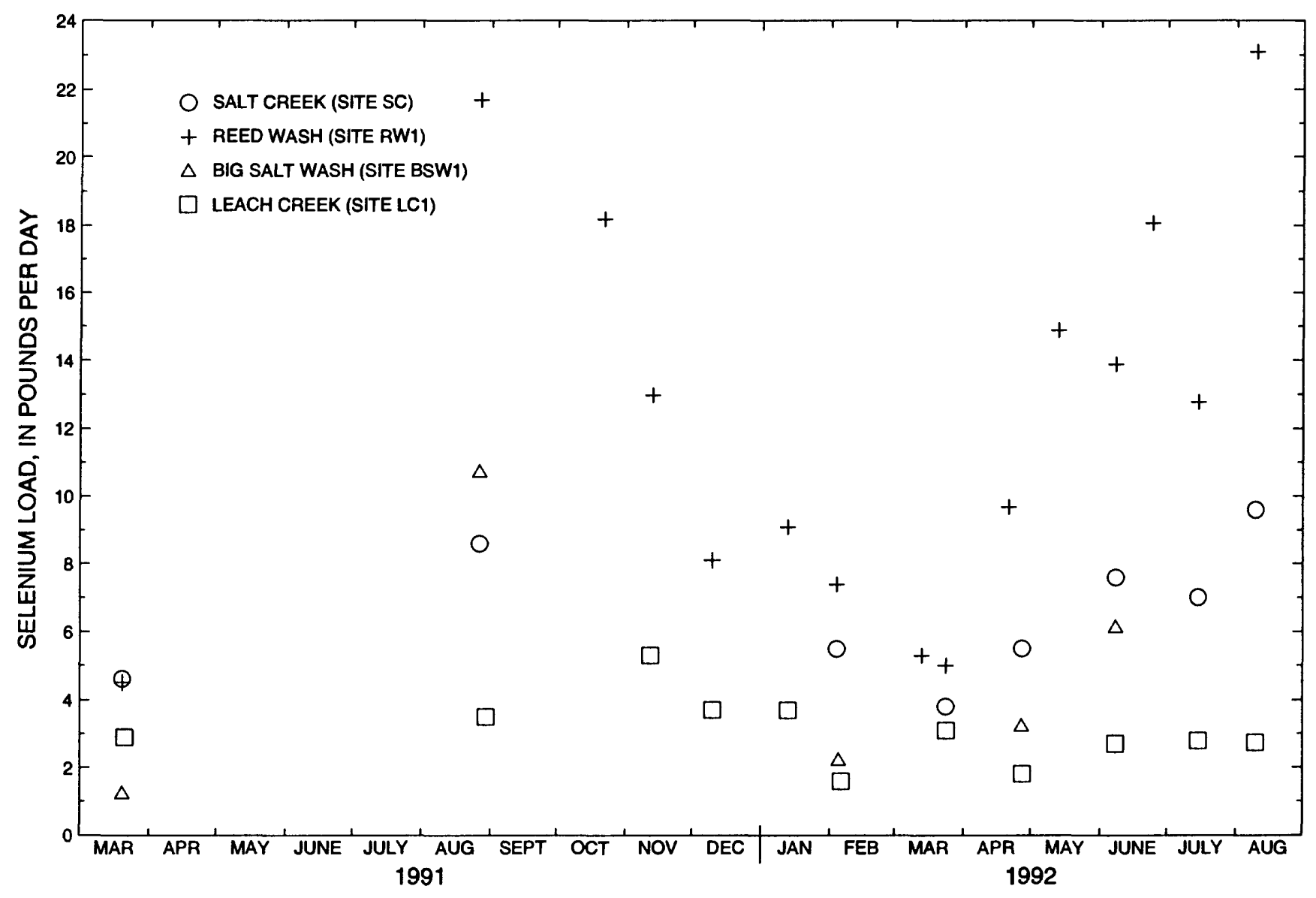

Figure 37. Selenium loads in Salt Creek at site SC, Reed Wash at site RW1, Big Salt Wash at site BSW1, and Leach Creek at site LC1, March 1991-August 1992. 
at site RW1 during the irrigation season. Water levels in shallow wells in the Grand Valley are higher during the irrigation season than during the nonirrigation season, which indicates the potential for increased ground-water discharge into tributary streams, washes, and drainage ditches that dissect the valley. Higher selenium concentrations could occur during the irrigation season because of more oxidizing conditions in ground water or by the flushing of soluble salts that contain selenium. Water samples collected from Reed Wash during this study were not affected by surface runoff from precipitation or snowmelt; therefore, seasonal differences in selenium loads were not caused by natural runoff.

There is a statistically significant (significance level less than 0.001 ) relation of seasonally weighted mean selenium load to drainage-basin area within the irrigated area for the 20 reconnaissance sites in the Grand Valley (fig. 38). The coefficient of determination of the relation shown in figure 38 is 0.74 . The four streams with the largest selenium loads in the Grand Valley also have the largest drainage areas within the irrigated area of the Grand Valley. That relation is not surprising because the larger drainage basins would tend to have more miles of canals, laterals, and ditches and more irrigated acreage than smaller basins; therefore, the large basins would have greater recharge to shallow ground water from distributionsystem losses and deep percolation. The selenium yield, in pounds per day per 100 acres of drainage area, was determined for the 20 sites in figure 38 by dividing the seasonally weighted mean selenium load of all the samples collected at a site by the drainage-basin area within the irrigated boundaries (bounded by the Government Highline Canal) and multiplying by 100 . The largest selenium yields were $0.115(\mathrm{lb} / \mathrm{d}) / 100$ acres for the drain near Clifton at site CF1 and $0.088(\mathrm{lb} / \mathrm{d}) / 100$ acres for Reed Wash at site RW1. Most basins had selenium yields between 0.020 and $0.060(\mathrm{lb} / \mathrm{d}) / 100$ acres. The selenium yields were less than $0.01(\mathrm{lb} / \mathrm{d}) / 100$ acres for Appleton Drain (site AD in fig. 30), Lewis Wash (site LW in fig. 31), an unnamed drainage east of Clifton at site CF2, and Orchard Mesa Drain (site OMD).
General surficial geology does not seem to explain differences in selenium loads in the Grand Valley. For example, the selenium load for Reed Wash at site RW1 is about twice the selenium load for the Salt Creek Basin at site SC (fig. 38), although the drainage-basin areas within the irrigated area are about equal for both basins. General geologic differences between the basins are not readily apparent because most of the irrigated soil in both basins is derived either from alluvium on Mancos Shale or Mancos Shale residuum (fig. 5A). However, based solely on field observations, a higher percentage of the Reed Wash Basin is irrigated compared to the Salt Creek Basin, which could explain some of the difference in selenium loads between the basins. Land-use factors and small-scale geologic differences might explain some of the differences in selenium loads among tributary streams in the Grand Valley.

\section{Dissolved Solids and Major Constituents and Relations to Selenium}

The irrigated areas in the Uncompahgre Project and in the Grand Valley have been identified in salinity studies by the BOR (1978, 1982) as major sources of salt (dissolved solids) to the upper Colorado River. These studies indicated that the Uncompahgre Project contributes about 360,000 tons/yr and the Grand Valley about 580,000 tons/yr of salt to the Colorado River. Because of previous, ongoing, and proposed salinity-control projects in the Uncompahgre Project and in the Grand Valley, there is an interest in determining if there are relations of selenium to dissolved solids and if projects designed to decrease dissolved-solids loading could affect selenium loading. Relations of selenium concentrations and loads to dissolvedsolids concentrations and loads were analyzed to determine if source areas of selenium also are source areas of dissolved solids. The major ions that compose dissolved solids and their relations to selenium also are discussed. 


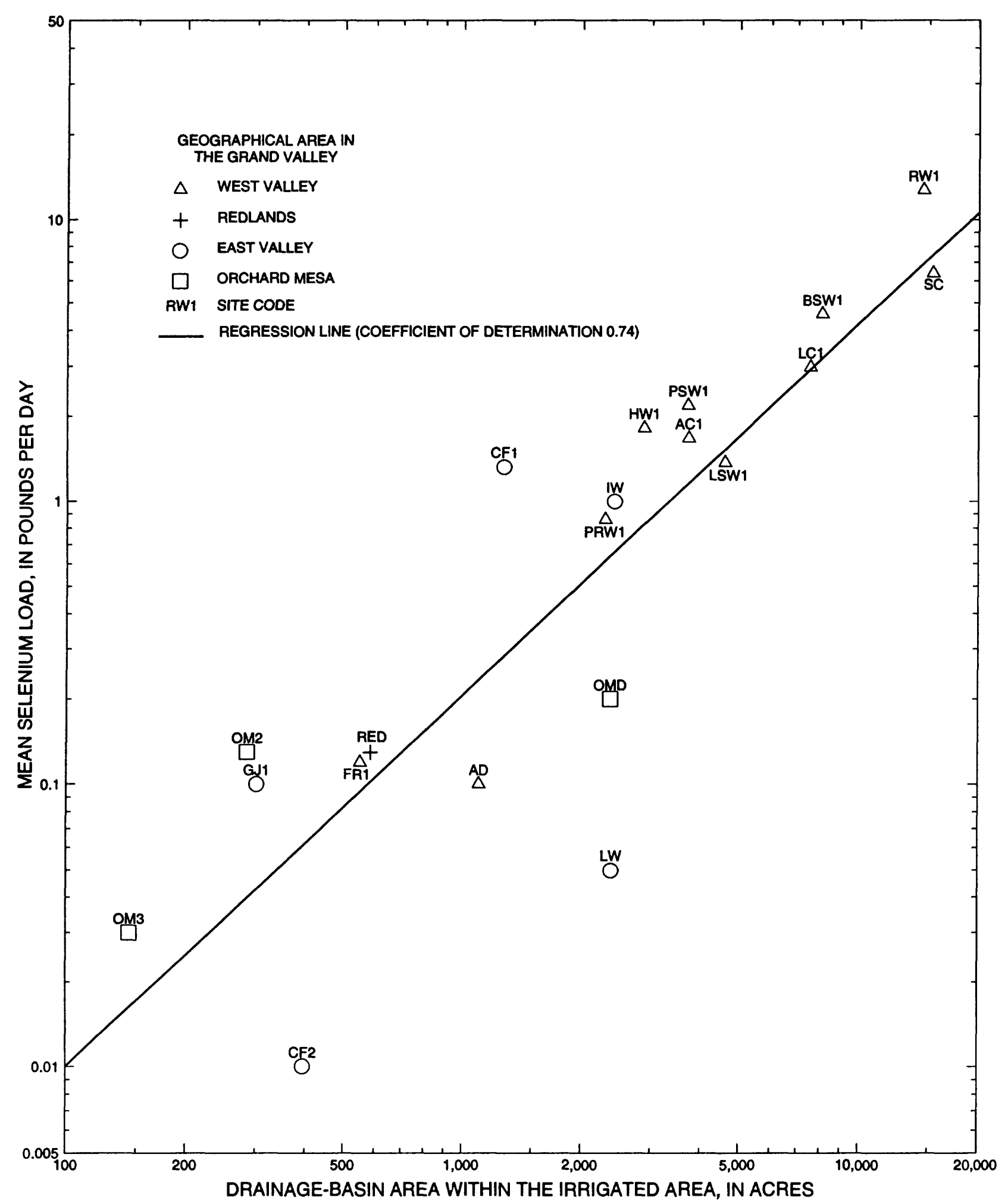

Figure 38. Relation of seasonally weighted mean selenium load to drainage-basin area within the irrigated area for 20 basins in the Grand Valley. 


\section{Dissolved Solids}

Irrigation water from the Gunnison River (through the Gunnison Tunnel) into the Uncompahgre Project had dissolved-solids concentrations less than $150 \mathrm{mg} / \mathrm{L}$ and was a calcium bicarbonate water. Dissolved-solids concentrations in the Uncompahgre River at Colona during 1991-92 ranged from about 250 to $450 \mathrm{mg} / \mathrm{L}$ and was a calcium sulfate bicarbonate water. Both rivers are regulated by reservoirs, and dissolved-solids concentrations in the Gunnison and Uncompahgre Rivers upstream from the Uncompahgre Project had less seasonal variation than is typical of streams in western Colorado. There is considerable variability in the quality of irrigation water delivered within the Uncompahgre Project. Water into the South and West Canals (fig. 25) is directly from the Gunnison Tunnel, and this irrigation water had low dissolved-solids and major-ion concentrations. Water diverted from the Uncompahgre River into the six canals downstream from the South Canal (figs. 25 and 26) has increasing dissolved-solids and major-ion concentrations in the downstream direction compared to the original irrigation water because of the effects of surface-return flow, irrigation drainage, and consumptive losses.

The median dissolved-solids concentration for nonirrigation-season samples from the western side of the Uncompahgre Project was $1,160 \mathrm{mg} / \mathrm{L}$, and concentrations ranged from 648 to $4,840 \mathrm{mg} / \mathrm{L}$. The median dissolved-solids concentration for nonirrigation-season samples from the eastern side was $4,110 \mathrm{mg} / \mathrm{L}$, and concentrations ranged from 1,470 to $6,380 \mathrm{mg} / \mathrm{L}$. Water composition generally was a mixed-cation sulfate water. Sulfate composed more than 70 percent of the anion concentration in most nonirrigation-season samples, and sulfate was greater than 80 percent of the anion composition in most nonirrigation-season samples from the eastern side.

Water samples collected from the Colorado River near Cameo at site COL2 (fig. 31) are representative of water quality of the irrigation-supply water for all irrigated areas in the Grand Valley, except the Redlands area, which is irrigated by water from the Gunnison River. During 1991-92, dissolvedsolids concentrations in discrete samples collected at site COL2 ranged from 196 to $654 \mathrm{mg} / \mathrm{L}$ during April through October. Water composition at site COL2 varied during the irrigation season and had higher ion percentages of calcium bicarbonate during snowmelt runoff and higher percentages of sodium chloride during low flow. Water samples from the Gunnison River at site GUN6, about $7 \mathrm{mi}$ upstream from the irrigation diversion for the Redlands area, had slightly higher dissolved-solids concentrations than samples from site COL2 and was a calcium sulfate water.

The median dissolved-solids concentration was $3,600 \mathrm{mg} / \mathrm{L}$ for nonirrigation-season samples in the Grand Valley, and concentrations ranged from 1,760 to $6,170 \mathrm{mg} / \mathrm{L}$. There were no winter-water diversions in the Grand Valley when nonirrigation-season samples were collected; therefore, nonirrigation-season samples from streams probably consisted of shallow ground-water discharge from irrigated areas. The nonirrigation-season samples were a mixed-cation sulfate water, and sulfate accounted for more than 70 percent of the anion equivalent concentration. The nonirrigation-season samples often had higher percentages of magnesium and sulfate and lower percentages of sodium, chloride, and bicarbonate compared to irrigation water from the Colorado River.

The Pearson correlation coefficients of selenium concentration to specific conductance, dissolvedsolids, major-ion, boron, and uranium concentrations in surface-water samples collected within the irrigated areas, separated by irrigation and nonirrigation seasons, are listed in table 21. The Uncompahgre Project data were separated into the western and the eastern sides of the Uncompahgre River, and the Grand Valley data were separated into areas north and south of the Colorado River. Irrigation on the western side of the Uncompahgre Project and in the Grand Valley south of the Colorado River primarily is on terrace deposits; irrigation on the eastern side of the Uncompahgre Project and in the Grand Valley north of the Colorado River primarily is on Mancos Shale or on alluvium containing substantial amounts of shale.

Many of the correlation coefficients of selenium to the variables listed in table 21 were less than 0.50 for samples collected in Mancos Shale areas (eastern side of Uncompahgre Project; north of Colorado River). In some instances, relatively large sample sizes (more than 30 samples) probably improved the chance that the correlations of selenium 
with other water-quality constituents would be statistically significant. Most of the correlations for the irrigation-season samples from the eastern side of the Uncompahgre Project and for the nonirrigationseason samples from the Grand Valley north of the Colorado River were not statistically significant (at a significance level of 0.05 ). Specific conductance usually is highly correlated with dissolved-solids concentrations, and because it can be measured in the field, specific conductance can be used to monitor dissolved-solids concentrations. Selenium concentrations seemed to have greater variability than specific conductance in irrigated areas on Mancos Shale, which results in the relatively low correlations of selenium and specific conductance (table 21). For that reason, specific conductance probably is not an accurate indicator of selenium concentration for irrigated areas on Mancos Shale for broad geographical areas.

If data for specific sites are used, relations of selenium to dissolved-solids concentrations and specific conductance improved markedly because the variance in selenium concentrations between sites or drainage basins was removed. Some of the variance between drainage basins could be caused by differences in geology and land use. Relations of selenium concentration to specific conductance for samples collected during 1991-92 from Loutsenhizer Arroyo (sites LZA1 and LZAM) and Reed Wash (site RW1) are shown in figure 39. Specific conductance was used instead of dissolvedsolids concentrations because there were more data for specific conductance, but regressions using dissolved-solids concentrations would have essentially the same relations. The coefficients of determination were 0.97 for the Loutsenhizer Arroyo relation and 0.94 for the Reed Wash relation. Coefficients of determination were greater than 0.89 for relations of selenium to specific conductance for Cedar Creek (site CD1), Salt Creek (site SC), and Leach Creek (site LC1). For Dry Creek (site DRY1), which does not drain Mancos Shale lands to a great extent, the coefficient of determination was only 0.65 .

The salinity-control projects, which are designed to decrease dissolved-solids loads, could have an effect on selenium loads in the irrigated areas of the Uncompahgre Project area and the Grand Valley. The salinity-control projects are designed to decrease distribution-system losses and deep percolation of applied water, which would result in less recharge to shallow aquifers in the Mancos Shale.

Table 21. Pearson correlation coefficients of selenium concentration to specific conductance and to dissolved-solids, major-ion, boron, and uranium concentrations for the Uncompahgre Project and the Grand Valley

[Areas of the Uncompahgre Project are west or east of the Uncompahgre River; areas of the Grand Valley are north or south of the Colorado River; irr, irrigation season; non, nonirrigation season; *, correlation not significant at 0.05 probability level; --, correlation not reported for sample sizes less than 6; samples from mainstem rivers and reference sites were not included]

\begin{tabular}{|c|c|c|c|c|c|c|c|c|c|c|c|c|}
\hline Area & Season & $\begin{array}{l}\text { Specific } \\
\text { con- } \\
\text { duc- } \\
\text { tance }\end{array}$ & $\begin{array}{l}\text { Dis- } \\
\text { solved } \\
\text { solids }\end{array}$ & $\begin{array}{l}\text { Cai- } \\
\text { cium }\end{array}$ & $\begin{array}{l}\text { Mag- } \\
\text { ne- } \\
\text { sium }\end{array}$ & $\begin{array}{l}\text { Sod- } \\
\text { ium }\end{array}$ & $\begin{array}{l}\text { Sul- } \\
\text { fate }\end{array}$ & $\begin{array}{l}\text { Aika- } \\
\text { linity }\end{array}$ & $\begin{array}{l}\text { Chio- } \\
\text { ride }\end{array}$ & $\begin{array}{c}\text { Nitrate } \\
\text { plus } \\
\text { nitrite }\end{array}$ & Boron & $\begin{array}{l}\text { Uran- } \\
\text { ium }\end{array}$ \\
\hline \multicolumn{13}{|c|}{ UNCOMPAHGRE PROJECT } \\
\hline West & Irr & 0.77 & 0.78 & 0.75 & 0.69 & 0.57 & 0.79 & $-0.03 *$ & $-0.11 *$ & 0.91 & $0.23 *$ & $0.42 *$ \\
\hline West & Non & .84 & .85 & .69 & .74 & .86 & .86 & .41 & $.27 *$ & .57 & .88 & - \\
\hline East & Irr & $.20^{*}$ & $.19^{*}$ & .49 & $-.12 *$ & $-.22 *$ & $-.11^{*}$ & $.36^{*}$ & $-.04 *$ & .82 & $-.04 *$ & $-.17 *$ \\
\hline East & Non & .50 & .45 & .47 & $.15^{*}$ & .48 & .42 & $-.07 *$ & $.27^{*}$ & .71 & .43 & -- \\
\hline \multicolumn{13}{|c|}{ GRAND VALLEY } \\
\hline North & Irr & .71 & .77 & .85 & .68 & $.25^{*}$ & .75 & .44 & $.17^{*}$ & .80 & .50 & .54 \\
\hline North & Non & $.13^{*}$ & $.15^{*}$ & .44 & $.17^{*}$ & $-.08^{*}$ & $.14^{*}$ & $-.08 *$ & $-.09 *$ & .61 & $.08^{*}$ & .65 \\
\hline South & Irr & -- & -- & -- & -- & -- & -- & - & -- & -- & -- & -- \\
\hline South & Non & $-.02 *$ & $-.16^{*}$ & $-.36^{*}$ & $.36 *$ & $.39^{*}$ & $-.24^{*}$ & $.43^{*}$ & $-.51^{*}$ & .93 & $.46^{*}$ & -. \\
\hline
\end{tabular}




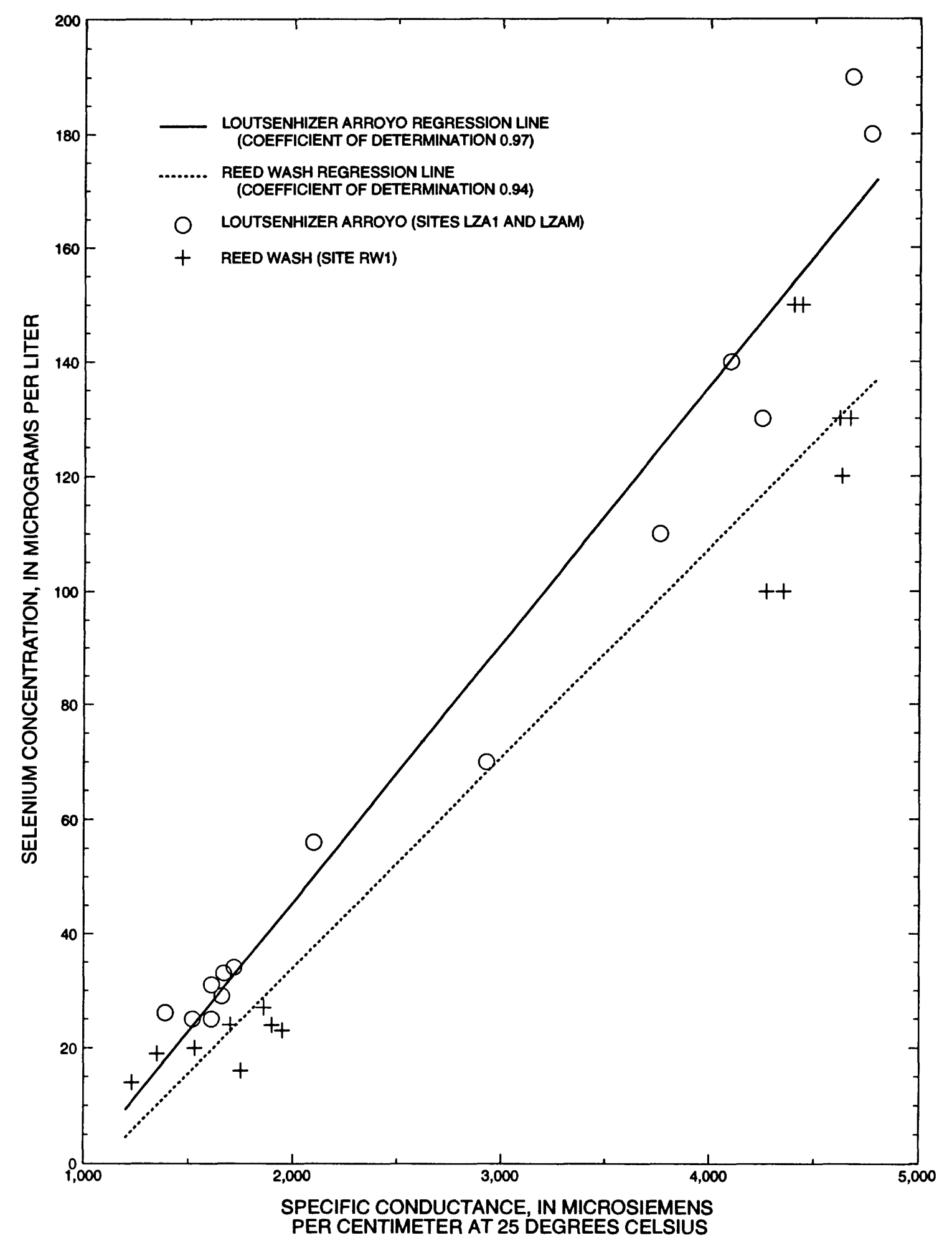

Figure 39. Relations of Selenium concentration to specific conductance for Loutsenhizer Arroyo and Reed Wash. 
Less recharge to aquifers in the Mancos Shale would decrease the quantity of irrigation-drainage discharge, which should decrease dissolved-solids loads. Linearregression relations of selenium loads to dissolvedsolids loads were determined for major tributary streams in the Uncompahgre Project and the Grand Valley. The relations of selenium and dissolved-solids loads among drainage basins are highly variable, and coefficients of determination range from about 0.32 to 0.90 . For some streams, additional variables apparently are needed to relate selenium load to dissolved-solids load. The load relations for the two tributary streams that had the largest selenium loads in the study area, Loutsenhizer Arroyo and Reed Wash, are shown in figure 40 . The load relation for Loutsenhizer Arroyo (coefficient of determination 0.36 ) was much weaker than the relation for Reed Wash (coefficient of determination 0.82). Reasons why the relation is less well defined for Loutsenhizer Arroyo are not known. Loutsenhizer Arroyo and Reed Wash drain irrigated areas that are predominately on soils derived from shale, and the major land use in both drainage basins is irrigated agriculture. Neither basin had been substantially affected by urbanization.

The relations of selenium and dissolved-solids loads for tributary streams had positive slopes, which might indicate that a decrease in dissolved-solids load in a particular drainage basin could be accompanied by a decrease in selenium load. Such relations could imply that the salinity-control projects, which are designed to decrease dissolved-solids loads from irrigated areas, also could decrease selenium loads. Potential decreases in dissolved-solids loads and selenium loads resulting from salinity-control projects assume that the projects decrease the quantity of ground-water discharge (irrigation drainage) and that the concentrations of dissolved solids and selenium in ground water are relatively unchanged. Actual effects of salinity-control projects on selenium loads have not been measured in field studies in the Uncompahgre Project or in the Grand Valley.

Gains and losses of dissolved-solids loads in the Uncompahgre River in February 1992 had a similar pattern as selenium loads. Dry Creek discharged the largest dissolved-solids load into the river, and Loutsenhizer Arroyo contributed the second largest load to the river. Dry Creek had about four times greater stream discharge than Loutsenhizer
Arroyo (at site LZAM downstream from the Garnet Canal diversion). Part of the dissolved-solids load in Dry Creek in February 1992 probably was from winter water that was diverted from the Uncompahgre River.

For the 20 reconnaissance sites in the Grand Valley, streams that had the largest selenium loads (fig. 36) also had the largest dissolved-solids loads. The largest seasonally weighted mean dissolvedsolids loads for 1991-92 were 318 tons/d for Reed Wash at site RW1 (13 samples) and 271 tons/d for Salt Creek at site SC (6 samples). Generally, the relative differences in dissolved-solids loads among the 20 sites were less pronounced than were differences in selenium loads. The dissolved-solids load per unit drainage-basin area is the dissolved-solids yield. Data for 15 of the basins in the Grand Valley shown in figure 36 have dissolved-solids yield data listed in a BOR report (1978), and a plot of the relation of estimated selenium yield to estimated dissolvedsolids yield for these 15 basins is shown in figure 41 . The selenium and dissolved-solids yields are based on the total drainage-basin area within the irrigated area and not on irrigated acreage within the basin. The highly significant coefficient of determination of 0.81 (significance level less than 0.001) for the relation of selenium yield to dissolved-solids yield for the 15 basins shown in figure 41 implies that drainage basins in the Grand Valley that have high dissolvedsolids yields have high selenium yields.

\section{Chloride and Evaporative Concentration}

By assuming chloride is a conservative ion, a relation of selenium and chloride concentrations was used to analyze possible effects of evaporative concentration on selenium concentrations in the Grand Valley. Mass-balance methods were used to estimate a chloride budget for the Grand Valley for water years 1976-92. The flow-weighted chloride concentration of the Colorado River downstream from the Grand Valley (site COL8) was $54 \mathrm{mg} / \mathrm{L}$, compared to $51 \mathrm{mg} / \mathrm{L}$ for the combined inflow of the Colorado and Gunnison Rivers into the Grand Valley. The small increase in chloride concentration could result from consumptive water loss in the Grand Valley by evaporative concentration of the irrigation water or from computational errors. 

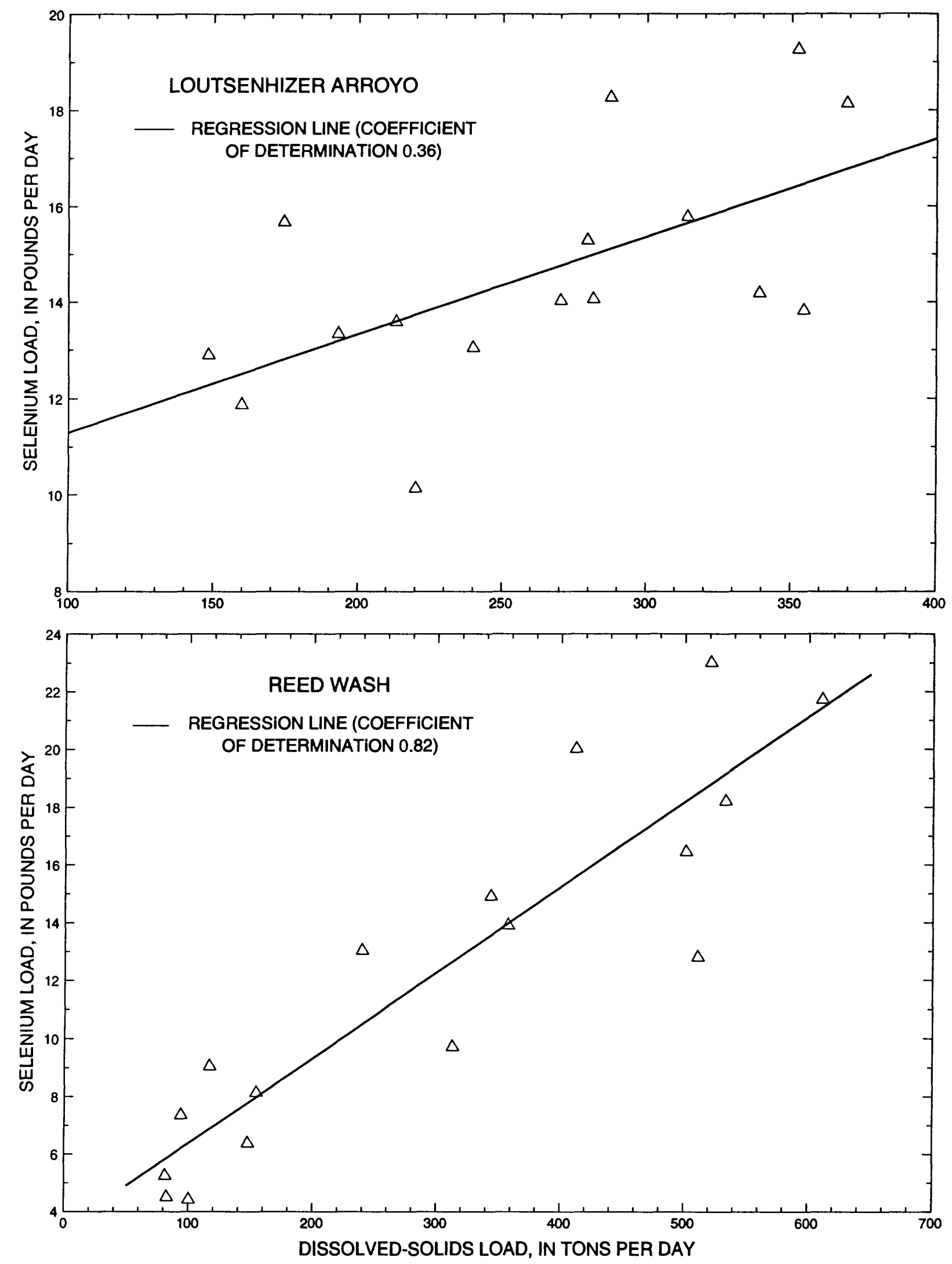

Figure 40. Relations of selenium load to dissolved-solids load for Loutsenhizer Arroyo (site LZA1) and Reed Wash (site RW1). 


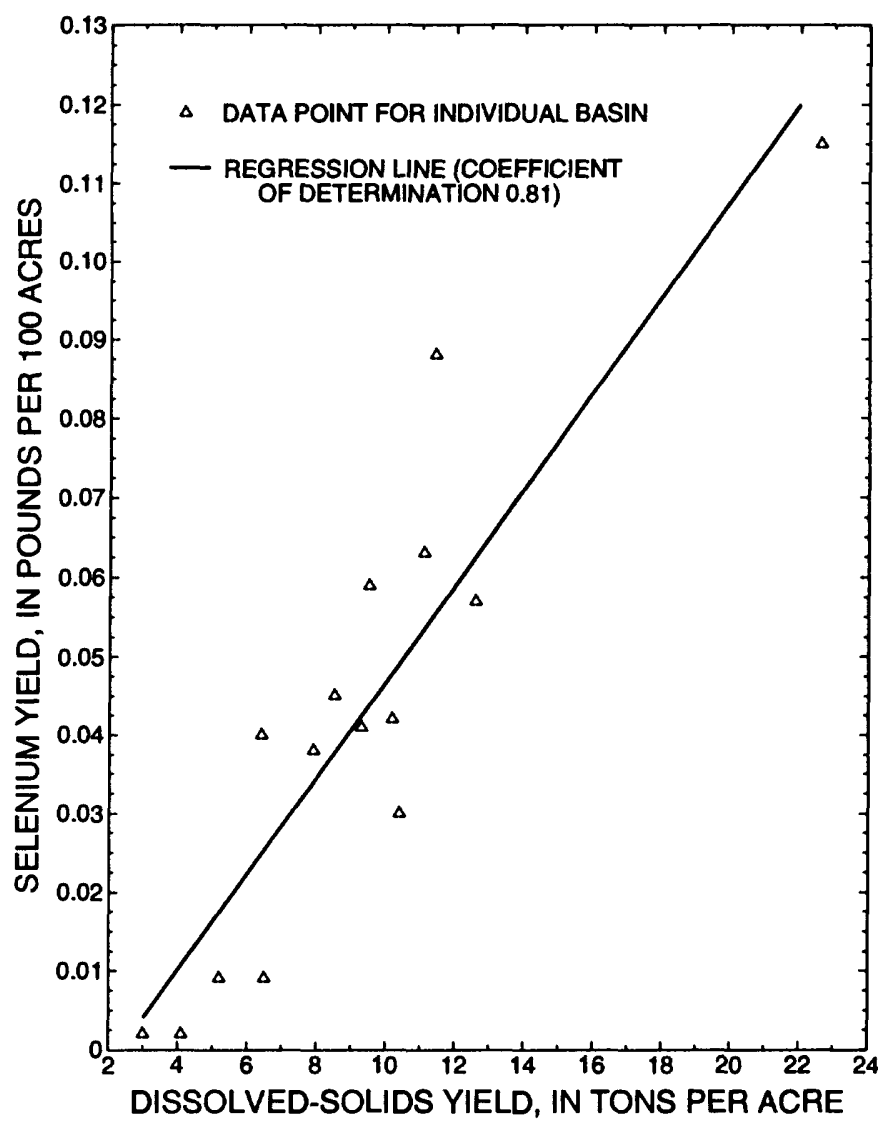

Figure 41. Relation of estimated selenium yield based on sampling during 1991-92 to estimates of dissolved-solids yield by the Bureau of Reclamation for 15 basins in the Grand Valley.

Selenium and chloride concentrations in irrigation drainage from the Grand Valley are plotted with the evaporative-concentration line in figure 42 . The evaporative-concentration line is constructed by projecting mean irrigation-season concentrations of $1 \mu \mathrm{g} / \mathrm{L}$ for selenium and $107 \mathrm{mg} / \mathrm{L}$ for chloride for irrigation water from the Colorado River along a 1:1 line. Because the chloride concentrations predicted from the evaporative-concentration line are in the same range as the chloride concentrations of the samples (fig. 42), the chloride concentrations in irrigation drainage could be caused by simple evaporation. The selenium concentrations of the samples are much greater than the selenium concentrations predicted from the evaporative-concentration line; therefore, simple evaporation of irrigation water does not account for the selenium concentrations in the Grand Valley (fig. 42). Many selenium concentrations were about 5 to 100 times greater than the concentrations predicted by evaporative concentration, implying that the Grand Valley is a source area for selenium.

\section{Other Major Constituents}

Much of the gain in dissolved solids in irrigation water in the Uncompahgre Project and in the Grand Valley was from gain in calcium, magnesium, sodium, and sulfate ions. Weathering of shale detritus or of evaporite sulfate minerals would contribute calcium, magnesium, sodium, and sulfate. Dissolution of carbonate minerals by irrigation drainage could result in a gain in calcium, magnesium, and sodium. Cation exchange on clay minerals could substitute calcium and magnesium ions for sodium ions, or vice versa. Dissolution of gypsum and oxidation of sulfides, such as pyrite, would produce sulfate. Only a small part of the increase in dissolved solids was the result of increases in alkalinity concentrations (almost all the alkalinity was bicarbonate ions based on the $\mathrm{pH}$ of samples).

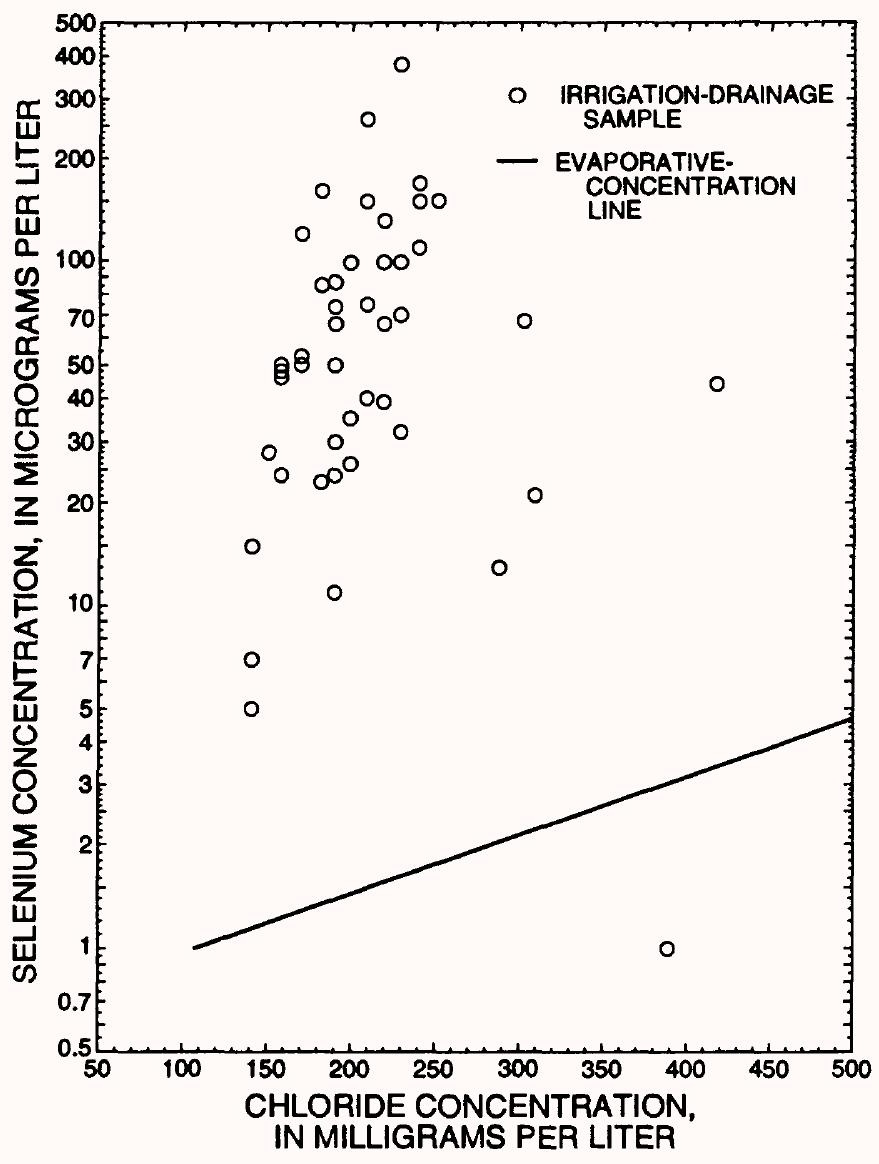

Figure 42. Selenium and chloride concentrations in irrigationdrainage samples from the Grand Valley, November 1991March 1992, and the estimated evaporative-concentration line. 
Nonirrigation-season samples from the Uncompahgre Project and the Grand Valley were supersaturated with the carbonate minerals calcite and dolomite. The computer program WATEQ4F (Ball and Nordstrom, 1991) was used to compute ion speciation, mineral saturation, and mineralsaturation indices for selected samples collected from tributary streams and ditches during February and March 1992. Alkalinity concentrations were limited because equilibrium solubilities controlled the carbonate and bicarbonate concentrations. The irrigation water coming into the Uncompahgre Project and into the Grand Valley was undersaturated with gypsum (calcium sulfate). More than 50 percent of the samples from the Mancos Shale areas (the eastern side of the Uncompahgre Project and most of the Grand Valley) were approximately at equilibrium with gypsum, and the remainder of the samples was slightly undersaturated with gypsum. The change in saturation indices for gypsum from undersaturated in the irrigation-supply water to saturation or near saturation in irrigation drainage from Mancos Shale areas could imply that dissolution of gypsum is occurring in the study area. Dissolution of other evaporite minerals formed by weathering of Mancos Shale, such as epsomite and thenardite, would produce magnesium, sodium, and sulfate.

Sulfate concentrations were much higher in water samples from the irrigated areas compared to sulfate concentrations in irrigation-supply water for the Uncompahgre Project and in the Grand Valley. Sulfate concentrations were about $20 \mathrm{mg} / \mathrm{L}$ in irrigation water diverted through the Gunnison Tunnel, based on six samples collected during 1987-92 from the Gunnison River downstream from the tunnel diversion (site GUN1 in fig. 23) and from the South Canal. Sulfate concentrations were about 150 to $250 \mathrm{mg} / \mathrm{L}$ in samples collected during the irrigation season from the Uncompahgre River upstream from the Uncompahgre Project (site UC1 in fig. 25). For samples collected during the nonirrigation season, sulfate concentrations ranged from 200 to $3,100 \mathrm{mg} / \mathrm{L}$ for the western side of the Uncompahgre Project and from 790 to $4,200 \mathrm{mg} / \mathrm{L}$ for the eastern side of the project. Sulfate concentrations in irrigation-supply water from the Colorado River upstream from the Grand Valley (site COL2) generally ranged from about 50 to $175 \mathrm{mg} / \mathrm{L}$. Sulfate concentrations in non-irrigation-season samples collected in the Grand Valley ranged from 760 to $3,900 \mathrm{mg} / \mathrm{L}$.

Differences in the distribution of selenium and sulfate might indicate differences in source areas, mobility, deposition, and transport of these constituents (Izbicki, 1989). Ratios of the concentrations of sulfate to selenium were computed for water samples from the study area. Lower ratios of sulfate to selenium concentrations in water samples could imply that selenium was enhanced in the water compared to sulfate and might indicate the most important selenium-source areas. In samples from the Uncompahgre Project, sulfate to selenium ratios generally were greater than 100,000 for samples from reference sites (sites outside the irrigated area) and for samples of irrigation-supply water from the Gunnison and Uncompahgre Rivers. Ratios also were greater than 100,000 for irrigated areas that had low selenium concentrations on the western side of the project, such as in the Happy Canyon Creek, Spring Creek, and Roubideau Creek Basins (figs. 25 and 26). Sulfate to selenium ratios were about 40,000 to 70,000 in samples from lower Dry Creek, Cummings Gulch, and Seep Creek, and these lower ratios might partly be the result of seleniumenhanced water from the Uncompahgre River being transported into these basins by the Ironstone Canal. Sulfate to selenium ratios were lower for samples collected in the nonirrigation season from the eastern side of the project and generally ranged from 10,000 to 30,000 . The lowest ratios were for samples from areas having some of the higher selenium concentrations, such as the Loutsenhizer Arroyo Basin, an unnamed drainage near Read (upstream from site RD1), and from sites GAR2 and UNGR in the Garnet Canal area.

The irrigation-supply water from the Colorado River upstream from the Grand Valley had sulfate to selenium ratios greater than 100,000 . Most irrigationdrainage samples from the Grand Valley had ratios between 10,000 and 60,000 , and the lowest ratios were for water samples from areas that had the higher selenium concentrations, such as East Salt Creek, upper Reed Wash, the East Branch of Reed Wash, sites IRD and LC2 in the Leach Creek Basin, and Indian Wash (figs. 30 and 31). The only samples collected in irrigated areas of the Grand Valley that 
had sulfate to selenium ratios greater than 100,000 were samples from areas of lower selenium concentrations, such as the ditches and washes represented by sites GJ1 and CF2 and sites on Orchard Mesa. The sulfate to selenium ratios for four of the five samples from reference sites on West Salt Creek, East Salt Creek, and Big Salt Wash were greater than 1,000,000, which implies that, in nonirrigated areas on Mancos Shale, sulfate was easily mobilized, but selenium was not readily mobilized.

The ratios of sulfate to selenium for pondwater samples were greater than the ratios for stream samples from Mancos Shale areas in the Uncompahgre Project area and in the Grand Valley. Six water samples from ponds in the Uncompahgre Project area had ratios between 110,000 and 400,000. The ratios of sulfate to selenium were 118,000 and 74,000 for samples from Reid Pond (site RDP in fig. 30) in the Grand Valley. The ponds are all located in Mancos Shale areas and probably receive some inflow of subsurface-irrigation drainage. Higher ratios for pond-water samples could indicate that chemical and biological processes were removing some of the selenium from ponds, but were not appreciably affecting sulfate concentrations.

Selenium and nitrite-plus-nitrate concentrations were significantly correlated (table 21 ) in the Uncompahgre Project and in the Grand Valley. Water samples from irrigated areas had considerably higher nitrite-plus-nitrate concentrations than irrigationsupply water, which is not unusual for agricultural areas where fertilizers are used on fields and where there are numerous small diary and cattle-feeding operations. Nitrite-plus-nitrate concentrations in irrigation-supply water and in samples from reference sites usually were less than $0.2 \mathrm{mg} / \mathrm{L}$. The median nitrite-plus-nitrate concentrations for nonirrigationseason samples collected in 1991-92 were $2.9 \mathrm{mg} / \mathrm{L}$ for the western side of the Uncompahgre Project, $7.6 \mathrm{mg} / \mathrm{L}$ for the eastern side, and $5.2 \mathrm{mg} / \mathrm{L}$ for the Grand Valley. Median concentrations do not include selenium data for reference sites, ponds, or mainsiem rivers. The maximum nitrite-plus-nitrate concentrations for 1991-92 for the Uncompahgre Project were $14 \mathrm{mg} / \mathrm{L}$ (selenium concentration $23 \mu \mathrm{g} / \mathrm{L}$ ) for the western side at site SEP2 (fig. 26) and $21 \mathrm{mg} / \mathrm{L}$ (selenium concentration $240 \mu \mathrm{g} / \mathrm{L}$ ) for the eastern side at site GAR2. However, a sample from a drainage ditch at site DR2 (fig. 26) had a nitrite-plusnitrate concentration of $73 \mathrm{mg} / \mathrm{L}$ in March 1993. That sample also had a selenium concentration of $600 \mu \mathrm{g} / \mathrm{L}$, which was the maximum selenium concentration in surface-water samples from the study area. The maximum nitrite-plus-nitrate concentration for 1991-92 in the Grand Valley was $46 \mathrm{mg} / \mathrm{L}$ (selenium concentration $100 \mu \mathrm{g} / \mathrm{L}$ ) for a drainage ditch near Clifton at site CF1 (fig. 31). However, site CF1 is near sewage-treatment ponds, and perhaps much of the nitrogen at site CF1 was from nonagricultural sources. Excluding site CF1, the maximum nitrite-plus-nitrate concentration in Grand Valley surface water was $19 \mathrm{mg} / \mathrm{L}$ at site RW4 on upper Reed Wash (fig. 30). The selenium concentration of $380 \mu \mathrm{g} / \mathrm{L}$ associated with that sample from site RW4 was the maximum selenium concentration in surface-water samples from the Grand Valley.

Because laboratory experiments have indicated that nitrate can oxidize selenium from Mancos Shale samples (Wright and McMahon, 1994; Wright, 1995), relations of selenium and nitrite-plus-nitrate concentrations in surface water in irrigated areas on Mancos Shale were examined. In the oxidized environment of surface water (excluding ponds), almost all of the nitrite-plus-nitrate determination represents nitrate. In surface-water samples from Mancos Shale areas, high selenium concentrations often were associated with high nitrite-plus-nitrate concentrations, although there were some samples with high selenium concentrations that did not contain unusually high nitrite-plus-nitrate concentrations. Also, a number of the samples from Mancos Shale areas that had some of the lower selenium concentrations were associated with some of the lower nitrite-plus-nitrate concentrations. The linear relations between selenium and nitrite-plusnitrate concentrations were examined using samples collected from tributary streams and ditches on the eastern side of the Uncompahgre Project and in the Grand Valley north of the Colorado River. Irrigation in these areas primarily is on soils derived from alluvium that contain variable quantities of shale detritus or is on soils derived from shale residuum. Samples collected only during the nonirrigation season (November through March) were used in 
the regression analysis, and most of those samples were representative of subsurface-irrigation drainage from shale areas. The relations shown in figure 43 are statistically significant (significance level 0.05), although the coefficients of determination for both relations do not exceed 0.50 . The relations in figure 43 indicate that higher selenium concentrations generally are accompanied by higher nitrite-plusnitrate concentrations. Statistical correlations between selenium and nitrite-plus-nitrate concentrations does not prove that a cause-and-effect mechanism actually exists in the field (that nitrate oxidizes selenium). If there are significant sources of selenium and nitrogen available, oxidizing conditions could cause high concentrations of both constituents, which could result in positive correlations between constituent concentrations in the ground water that is discharged into streams, washes, and ditches. However, there seems to be an association between high selenium concentrations and high nitrite-plus-nitrate concentrations in some surface-water samples collected in Mancos Shale areas in the Uncompahgre Project and in the Grand Valley.

\section{Other Trace-Constituent Concentrations}

Many concentrations of trace constituents potentially toxic to biota, such as arsenic, cadmium, copper, lead, mercury, and zinc, were about equal to or less than analytical reporting limits (table 22). In addition to selenium, Colorado has aquatic-life criteria (Colorado Department of Health, 1989) for arsenic, cadmium, chromium, copper, lead, mercury, uranium, and zinc. Except for mercury, concentrations of these trace constituents in surface-water samples were less than the chronic criteria established by the State. The criterion for mercury is $0.01 \mu \mathrm{g} / \mathrm{L}$, but the analytical reporting limit was $0.1 \mu \mathrm{g} / \mathrm{L}$; therefore, it is unknown if mercury concentrations exceeded the aquatic-life criterion. Cadmium was detected in only two samples, and mercury was detected in only one sample (table 22).

There was a substantial increase in boron concentrations from the applied irrigation water to irrigation-drainage water in the study area. Boron concentrations were about 10 to $50 \mu \mathrm{g} / \mathrm{L}$ in the irrigation-supply water for the Uncompahgre Project and the Grand Valley. In the Uncompahgre
Project area, the maximum boron concentration was $1,600 \mu \mathrm{g} / \mathrm{L}$ (table 22) in a drainage ditch at site ASH (fig. 26). In the Grand Valley, the maximum boron concentration was $790 \mu \mathrm{g} / \mathrm{L}$ in a drainage ditch at site GJ2 (fig. 31). In the Grand Valley, some of the highest boron concentrations were in smaller basins or drainage ditches. Boron concentrations generally ranged from about 250 to $600 \mu \mathrm{g} / \mathrm{L}$ in nonirrigationseason samples from the Uncompahgre Project and the Grand Valley.

Uranium was detected in all surface-water samples collected in the study area (table 22). The median uranium concentrations are lower for the Uncompahgre Project area than for the Grand Valley. All the samples from the Uncompahgre Project area that had uranium analysis were collected during the irrigation season, whereas almost one-half of the uranium data for the Grand Valley were obtained during the nonirrigation season. Many constituent concentrations are lower in the irrigation season compared to the nonirrigation season because of dilution by surface return flows. Median uranium concentrations of samples collected at the 20 reconnaissance sites in the Grand Valley were much higher for March 1991 (31 $\mu \mathrm{g} / \mathrm{L})$ than for August and September $1991(8.8 \mu \mathrm{g} / \mathrm{L})$. The two highest uranium concentrations from the Uncompahgre Project area were in samples from ponds $-62 \mu \mathrm{g} / \mathrm{L}$ at Ferrier Pond near Austin (site FRP in fig. 23) and $16 \mu \mathrm{g} / \mathrm{L}$ from Markley Pond (site MKP in fig. 26). Ferrier Pond was a reference site located outside of the irrigated area served by the Uncompahgre Project; the pond is located in Mancos Shale terrain and might receive irrigation drainage from mesas north of the pond. In the Grand Valley, the maximum uranium concentration was $83 \mu \mathrm{g} / \mathrm{L}$ (table 22 ) in a sample collected at site BSW3 (fig. 30), a reference site located on Big Salt Wash upstream from the Government Highline Canal. Surface-water samples that had some of the highest uranium concentrations in the Grand Valley were from sites that had high selenium concentrations, such as upper Reed Wash (site RW4) and Indian Wash (site IW). However, there also were high uranium concentrations in samples that had some of the lower selenium concentrations, such as samples from Orchard Mesa Drain (site OMD in fig. 31). 


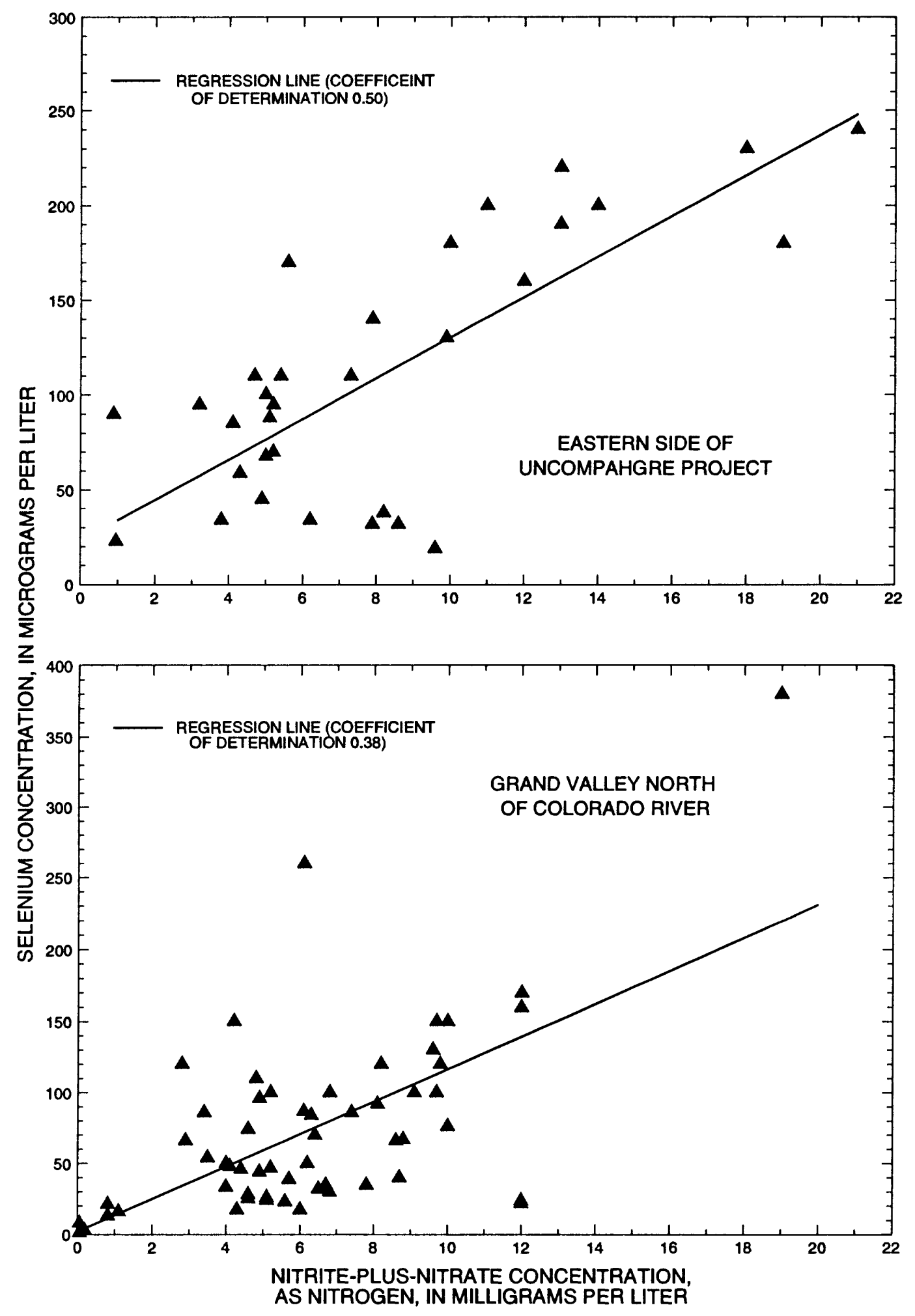

Figure 43. Relations of selenium to nitrite-plus-nitrate concentrations in water samples collected during the nonirrigation season from streams and ditches on the eastern side of the Uncompahgre Project and in the Grand Valley north of the Colorado River, 1991-92. 
Table 22. Summary of dissolved trace-constituent concentrations in surface-water samples from the Uncompahgre Project area and from the Grand Valley, 1991-92

[Concentrations in micrograms per liter; number detected is the number of samples reported as equal to or greater than the reporting limit; $<$, less than; includes samples collected from irrigated areas, reference sites, and mainstem rivers]

\begin{tabular}{|c|c|c|c|c|c|c|}
\hline $\begin{array}{c}\text { Trace } \\
\text { constituent }\end{array}$ & $\begin{array}{c}\text { Reporting } \\
\text { Ilmit(s) }\end{array}$ & $\begin{array}{c}\text { Number } \\
\text { of } \\
\text { sampies }\end{array}$ & $\begin{array}{l}\text { Number } \\
\text { detected }\end{array}$ & Medlan & Maximum & Minimum \\
\hline \multicolumn{7}{|c|}{ UNCOMPAHGRE PROJECT AREA } \\
\hline Arsenic & 1 & 37 & 30 & 1 & 3 & $<1$ \\
\hline Boron & 10 & 168 & 168 & 180 & 1,600 & 10 \\
\hline Cadmium & 1 & 61 & 1 & $<1$ & 1 & $<1$ \\
\hline Chromium & 1 & 37 & 7 & $<1$ & 3 & $<1$ \\
\hline Copper & 1 & 61 & 56 & 2 & 6 & $<1$ \\
\hline Lead & 1 & 61 & 6 & $<1$ & 4 & $<1$ \\
\hline Mercury & .1 & 61 & 0 & $<.1$ & $<.1$ & $<.1$ \\
\hline Molybdenum & 1 & 38 & 30 & 3 & 10 & $<1$ \\
\hline Selenium & 1 & 197 & 177 & 9 & 260 & $<1$ \\
\hline Uranium & .6 & 37 & 37 & 6.2 & 62 & 1.5 \\
\hline Vanadium & 1.0 & 38 & 37 & 2.7 & 7.7 & $<1.0$ \\
\hline Zinc & 3,10 & 61 & 45 & 6 & 59 & $<3$ \\
\hline \multicolumn{7}{|c|}{ GRAND VALLEY } \\
\hline Arsenic & 1 & 45 & 19 & $<1$ & 2 & $<1$ \\
\hline Boron & 10 & 122 & 122 & 280 & 790 & 20 \\
\hline Cadmium & 1,2 & 45 & 1 & $<1$ & 2 & $<1$ \\
\hline Chromium & 1 & 45 & 16 & $<1$ & 3 & $<1$ \\
\hline Copper & 1 & 45 & 43 & 1 & 4 & $<1$ \\
\hline Lead & 1 & 45 & 0 & $<1$ & $<1$ & $<1$ \\
\hline Mercury & .1 & 45 & 1 & $<.1$ & .2 & $<.1$ \\
\hline Molybdenum & 1 & 54 & 54 & 7.5 & 70 & 1 \\
\hline Selenium & 1 & 125 & 124 & 24 & 380 & $<1$ \\
\hline Uranium & .6 & 54 & 54 & 15.5 & 83 & 3.5 \\
\hline Vanadium & 1.0 & 54 & 54 & 4.5 & 15 & 2.4 \\
\hline Zinc & 3,10 & 45 & 33 & 9 & 30 & $<10$ \\
\hline
\end{tabular}

\section{Insecticides in the Grand Valley}

Pesticide data were collected in 1988 for the reconnaissance investigation of the Uncompahgre Project (Butler and others, 1991). Insecticide samples were collected at 11 outflow sites on tributaries and at two sites on the Colorado River in the Grand Valley in the summer of 1991. Samples were analyzed for 15 organophosphate and 11 carbamate insecticides. Analytical results indicated that most compounds were not detected or were detected at low concentrations. Nine organophosphate concentrations equaled or exceeded the reporting limit of $0.01 \mu \mathrm{g} / \mathrm{L}$.
Chlorpyrifos was detected in two samples at concentrations of 0.06 and $0.01 \mu \mathrm{g} / \mathrm{L}$. Diazinon was detected in five samples at concentrations of 0.01 to $0.12 \mu \mathrm{g} / \mathrm{L}$, and the maximum concentration was in the sample from Hunter Wash (site HW1 in fig. 30). Parathion was detected in two water samples at concentrations of $0.01 \mu \mathrm{g} / \mathrm{L}$ in Reed Wash (site RW1) and $0.09 \mu \mathrm{g} / \mathrm{L}$ in Persigo Wash (site PSW1). The aquatic-life criterion for parathion is $0.04 \mu \mathrm{g} / \mathrm{L}$ (U.S. Environmental Protection Agency, 1986). Butler and others (1991) reported parathion concentrations greater than $0.04 \mu \mathrm{g} / \mathrm{L}$ in the Gunnison and Uncompahgre Rivers 
in samples collected in July 1988. The only carbamate insecticide detected in water samples from the Grand Valley was a concentration of $0.8 \mu \mathrm{g} / \mathrm{L}$ (reporting limit $0.5 \mu \mathrm{g} / \mathrm{L}$ ) of 3-hydroxycarbofuran in a sample from Hunter Wash.

The insecticide data were collected in 1991 as a one-time reconnaissance of some of the pesticides used in the Grand Valley. A wide variety of crops are grown in the Grand Valley, and pesticide usage can vary depending on the type of crops grown and on the weeds and insects associated with the crops. Pesticides are applied at different times of the year. A much more comprehensive sampling program than was possible for the detailed study would be needed to more adequately assess pesticide concentrations in surface water in the study area.

\section{SELENIUM AND OTHER CONSTITUENTS IN BOTTOM SEDIMENT}

Bottom-sediment samples were collected from eight streams and washes and from four ponds at wetland sites in the study area for analysis of total selenium. Samples from streams were collected in March 1992, and samples from ponds were collected in June 1992. A sample was collected from a salt crust near an avocet nesting area adjacent to Brozina Pond in the northeast part of the Uncompahgre Project. A soil sample was collected on a hillside adjacent to Reid Pond in the Grand Valley where prince's plume (Stanleya pinnata), a selenium-indicator plant, was growing. Soluble and adsorbed selenium concentrations and the percent selenite were determined for the eight bottom-sediment samples collected from streams to provide additional information about selenium in bottom sediment.

\section{Sample Collection and Analytical Methods}

A BMH-53 sampler (Ward and Harr, 1990) was used to collect bottom-sediment samples from pool and backwater areas in streams where sediment deposits were sufficient for collection of samples. A minimum of six to eight cores were collected and composited in a stainless-steel bucket using a stainless-steel spoon. The salt-crust sample was a surficial sample collected using a spoon, and the soil sample was collected using a spoon and shovel at the base of prince's plume plants at shallow depths (less than 6 in.). Bottom-sediment and soil samples were analyzed by the Geologic Division of the USGS in Lakewood, Colo. For bottom sediment, the lessthan $0.0625-\mathrm{mm}$ size fraction was analyzed for selenium, uranium, 40 trace constituents, total carbon, and organic carbon by methods described by Harms and others (1990). The samples for totalselenium analysis were digested in a mixture of nitric, perchloric, and hydrofluoric acids; dried; and redissolved in hydrochloric acid (Harms and others, 1990). The salt-crust and soil samples were analyzed for the same constituents on the less-than 2-mm size fraction.

A subsample of the bottom-sediment samples collected from streams was used for the analysis of soluble and adsorbed selenium and selenite. The subsamples were placed in glass jars, were frozen, and were shipped in dry ice. The soluble and adsorbed selenium were determined by sequential extractions on the bottom-sediment samples using potassium chloride $(\mathrm{KCl})$ and potassium phosphate $\left(\mathrm{K}_{2} \mathrm{HPO}_{4}\right)$ on the same sample (Fujii and others, 1988). The $\mathrm{KCl}$ extract was considered an approximation of soluble selenium, and the $\mathrm{K}_{2} \mathrm{HPO}_{4}$ extract an approximation of the adsorbed selenium on the sediment. Selenite concentrations were determined in each extract by methods described by Fio and Fujii (1990). Most of the selenate selenium probably was extracted by $\mathrm{KCl}$; therefore, the nonselenite fraction in the $\mathrm{KCl}$ extract was assumed to be selenate. The analyses of soluble and adsorbed selenium and selenite for bottom-sediment samples were done by the U.S. Geological Survey in Sacramento, Calif. (Roger Fujii, U.S. Geological Survey, written commun., 1992).

\section{Selenium Concentrations}

In general, selenium concentrations were greater in bottom-sediment samples from ponds than in samples from streams (table 23). All selenium concentrations listed in table 23 exceeded the upper base-line concentration of $1.4 \mu \mathrm{g} / \mathrm{g}$ for soils in the Western United States (Shacklette and Boerngen, 1984). Selenium concentrations greater than or equal 
to $4 \mu \mathrm{g} / \mathrm{g}$ in sediment are a level of concern for fish and wildlife because of food-chain bioaccumulation (Lemly and Smith, 1987). Selenium concentrations in bottom-sediment samples from the four ponds and the samples from Loutsenhizer Arroyo (site LZA1), Reed Wash (site RW1), Leach Creek (site LC1), and Indian Wash (site IW) exceeded $4 \mu \mathrm{g} / \mathrm{g}$ (table 23 ). The selenium concentration of $47 \mu \mathrm{g} / \mathrm{g}$ in the bottomsediment sample from Brozina Pond (site BZP) was similar to the selenium concentration of $41 \mu \mathrm{g} / \mathrm{g}$ reported for a bottom-sediment sample from Sweitzer Lake (Butler and others, 1991). Brozina Pond is about $3 \mathrm{mi}$ southeast of Sweitzer Lake in Mancos Shale terrain. Selenium is enriched in bottom sediment compared to water, but more so in ponds than in streams. The ratio of selenium concentrations in bottom-sediment samples to concentrations in water samples collected concurrently at each site ranged from 29 to 250 for streams and from 2,670 to 23,500 for ponds. The largest ratio of selenium concentrations was for Brozina Pond. The selenium concentrations in the salt crust collected adjacent to Brozina Pond and in the soil sample collected among selenium-indicator plants near Reid Pond were similar to selenium concentrations in bottom sediment from streams (table 23).

Total-selenium concentrations in bottom sediment from the three streams in the Uncompahgre Project (table 23) were slightly higher than totalselenium concentrations in soil samples (data in Crock and others, 1994) that were collected from irrigated fields in the same drainage basin. The median totalselenium concentration for 11 soil samples collected in the Cedar Creek Basin was $2.9 \mu \mathrm{g} / \mathrm{g}$, and the median for 15 soil samples collected in the Loutsenhizer Arroyo Basin was $3.5 \mu \mathrm{g} / \mathrm{g}$. The bottom-sediment samples collected at the outflow sites for these basins (sites CD1 and LZA1 in table 23) had slightly higher selenium concentrations than median concentrations in soil. Most of the irrigated land in Cedar Creek and Loutsenhizer Arroyo Basins consists of soils derived from residual Mancos Shale or of alluvium derived primarily from shale. The total-selenium concentration in the bottom-sediment sample from Dry Creek is about twice the median concentration in irrigated soils in the Dry Creek Basin. Irrigated soils in Dry Creek

Table 23. Concentrations of selenium, uranium, total carbon, and organic carbon in bottom-sediment, salt-crust, and soil samples

[Sample types are: bot, bottom sediment; crust, sample from a salt crust adjacent to Brozina Pond; soil, a shallow soil sample from a hillside near Reid Pond where prince's plume, a selenium-indicator plant, was present; $\mu \mathrm{g} / \mathrm{g}$, micrograms per gram; bottom-sediment samples from streams were collected in March 1992 and samples from ponds in June 1992]

\begin{tabular}{|c|c|c|c|c|c|c|}
\hline $\begin{array}{c}\text { Site } \\
\text { number }\end{array}$ & $\begin{array}{l}\text { Stream } \\
\text { or pond }\end{array}$ & $\begin{array}{c}\text { Sample } \\
\text { type }\end{array}$ & $\begin{array}{c}\text { Selenium } \\
(\mu g / g)\end{array}$ & $\begin{array}{c}\text { Uranium } \\
(\mu g / g)\end{array}$ & $\begin{array}{c}\text { Total } \\
\text { carbon } \\
\text { (percent) }\end{array}$ & $\begin{array}{c}\text { Organic } \\
\text { carbon } \\
\text { (percent) }\end{array}$ \\
\hline \multicolumn{7}{|c|}{ UNCOMPAHGRE PROJECT AREA (sites shown in figs. 25 and 26) } \\
\hline DRY1 & Dry Creek & Bot & 2.0 & 4.46 & 2.32 & 0.67 \\
\hline $\mathrm{CD} 1$ & Cedar Creek & Bot & 3.5 & 5.18 & 2.96 & .88 \\
\hline LZA1 & Loutsenhizer Arroyo & Bot & 6.9 & 5.09 & 3.34 & .60 \\
\hline MKP & Markley Pond & Bot & 16 & 12.5 & 5.48 & 1.73 \\
\hline BZP & Brozina Pond & Bot & 47 & 12.1 & 9.30 & 2.72 \\
\hline BZP & Brozina Pond & Crust & 3.4 & 5.62 & 1.56 & .56 \\
\hline \multicolumn{7}{|c|}{ GRAND VALLEY (sites shown in figs. 30 and 31 ) } \\
\hline SC & Salt Creek & Bot & 1.9 & 4.55 & 2.32 & .51 \\
\hline MWP & Pond in Mack Wash & Bot & 21 & 6.28 & 5.62 & 2.21 \\
\hline RDP & Reid Pond & Bot & 15 & 7.39 & 3.79 & 1.95 \\
\hline RDP & Reid Pond & Soil & 4.1 & 4.90 & 3.48 & .94 \\
\hline RW1 & Reed Wash & Bot & 6.3 & 5.62 & 3.44 & .62 \\
\hline $\mathrm{AC} 1$ & Adobe Creek & Bot & 3.9 & 6.45 & 3.37 & .92 \\
\hline $\mathrm{LC} 1$ & Leach Creek & Bot & 5.6 & 5.45 & 3.35 & .93 \\
\hline IW & Indian Wash & Bot & 16 & 6.69 & 3.17 & 1.25 \\
\hline
\end{tabular}


Basin primarily are derived from terrace deposits and the Dakota Sandstone. Bottom sediment in tributary streams does not seem to be accumulating appreciable quantities of selenium when compared to the selenium content of the parent soils.

Selenium can be removed from water and immobilized in sediment through chemical and bacterial reduction, adsorption, coprecipitation, and deposition of plant and animal tissue (Lemly and Smith, 1987). In reducing environments, selenide and elemental selenium are very insoluble in water (Elrashidi and others, 1989), and selenium can become incorporated into the bottom sediment. Reducing conditions are likely near the bottom of most ponds and lakes; therefore, selenium enrichment in bottom sediment in ponds is not unexpected. The ponds, lakes, and wetlands in the Uncompahgre Project area and the Grand Valley probably function as sinks for selenium. Because selenium concentrations and loads in water discharging into and out of ponds and lakes were not measured, the magnitude of selenium removal in ponds and lakes in the study area was not determined. However, probably much more selenium is discharged to streams, washes, and ditches and transported out of the study area by the Gunnison and Colorado Rivers compared to the amount of selenium that is immobilized in pond and lake sediment.
Total-selenium concentrations are compared to the soluble and adsorbed selenium for bottomsediment samples from the eight streams in table 24 . The soluble selenium (the $\mathrm{KCl}$ extract) accounted for about 1 percent or less of the total-selenium concentration in all samples (table 24). The surface-adsorbed selenium (the $\mathrm{K}_{2} \mathrm{HPO}_{4}$ extract) accounted for about 2.5 to 16.9 percent of the total selenium. Except for site LC1, the soluble and adsorbed selenium extracted by $\mathrm{KCl}$ and $\mathrm{K}_{2} \mathrm{HPO}_{4}$ accounted for less than 10 percent of the total selenium in the eight bottom-sediment samples (table 24). The unextracted selenium could be chemically bound in oxides by precipitation or coprecipitation; could be present in insoluble, reduced chemical forms; or might be bound in organic matter. Fujii and others (1988) reported that the proportion of adsorbed selenium to total selenium in soils in the San Joaquin Valley in California ranged from 1 to 11 percent, which is similar to the results for bottom sediment from streams in the study area.

The percent selenite in both selenium extracts was 25 percent or less, except for the sample from Salt Creek (site SC) in the Grand Valley (table 24). Fujii and others (1988) reported that most of the surface-adsorbed selenium in soils was selenite, which, except for the sample from site SC, was not

Tabie 24. Concentrations of total, soluble, and adsorbed selenium and the percent selenite in bottom-sediment samples from eight streams, March 1992

[Concentrations in micrograms per gram; $\mathrm{KCl}$ - (potassium chloride-) extractable selenium approximates the soluble selenium, and $\mathrm{K}_{2} \mathrm{HPO}_{4}$ (potassium phosphate-) extractable selenium approximates the adsorbed selenium; selenium-extract data from Roger Fujii (U.S. Geological Survey, written commun., 1992)]

\begin{tabular}{|c|c|c|c|c|c|c|}
\hline \multirow{2}{*}{$\begin{array}{c}\text { Site } \\
\text { number }\end{array}$} & \multirow{2}{*}{$\begin{array}{c}\text { Stream } \\
\text { name }\end{array}$} & \multirow{2}{*}{$\begin{array}{c}\text { Total } \\
\text { seienium }\end{array}$} & \multicolumn{2}{|c|}{$\begin{array}{c}\text { KCl-extractable } \\
\text { (soluble) selenium }\end{array}$} & \multicolumn{2}{|c|}{$\begin{array}{l}\mathrm{K}_{2} \mathrm{HPO}_{4} \text {-extractable } \\
\text { (adsorbed) selenium }\end{array}$} \\
\hline & & & $\begin{array}{l}\text { Concen- } \\
\text { tration }\end{array}$ & $\begin{array}{l}\text { Percent } \\
\text { selenite }\end{array}$ & $\begin{array}{l}\text { Concen- } \\
\text { tration }\end{array}$ & $\begin{array}{l}\text { Percent } \\
\text { selenite }\end{array}$ \\
\hline \multicolumn{7}{|c|}{ UNCOMPAHGRE PROJECT AREA (sites shown in figs. 25 and 26) } \\
\hline DRY1 & Dry Creek & 2.0 & 0.010 & 0 & 0.054 & 25 \\
\hline CD1 & Cedar Creek & 3.5 & .007 & 1.5 & .181 & 18 \\
\hline LZA1 & Loutsenhizer Arroyo & 6.9 & .038 & 10 & .430 & 19 \\
\hline \multicolumn{7}{|c|}{ GRAND VALLEY (sites shown in figs. 30 and 31 ) } \\
\hline SC & Salt Creek & 1.9 & .027 & 26 & .128 & 90 \\
\hline RW1 & Reed Wash & 6.3 & .057 & 15 & .156 & 13 \\
\hline $\mathrm{ACl}$ & Adobe Creek & 3.9 & .048 & 12 & .291 & 19 \\
\hline LC1 & Leach Creek & 5.6 & .071 & 5.0 & .944 & 11 \\
\hline IW & Indian Wash & 16 & .076 & 14 & .813 & 10 \\
\hline
\end{tabular}


true for the bottom-sediment samples collected from the eight streams in the study area. Geochemical conditions in soils from the San Joaquin Valley might be different than geochemical conditions for bottom sediment in streams in the Uncompahgre Project and the Grand Valley.

For the 12 bottom-sediment samples collected from streams and ponds (table 23), there were significant (significance level 0.05 ) positive correlations between selenium concentrations and concentrations of total carbon and organic carbon. The correlation coefficient for selenium and organic carbon was 0.95 . Selenium was positively correlated with organic carbon in mining overburden in Wyoming (Naftz and Rice, 1989). Singh and others (1981) reported that organic carbon had a positive effect on selenate and selenite adsorption in semiarid soils. The sample from Brozina Pond that had the maximum selenium concentration of $47 \mu \mathrm{g} / \mathrm{g}$ in bottom sediment also had the maximum organic carbon concentration of 2.72 percent. Perhaps the high organic-carbon content of the bottomsediment sample from Indian Wash (site IW in table 23) might partly account for the high selenium concentration in Indian Wash bottom sediment compared to the other seven streams where bottom sediment was sampled.

\section{Other Trace-Constituent Concentrations}

Most other trace-constituent concentrations in bottom sediment (Butler and others, 1994) were less than the upper base lines for soil in the Western United States (Shacklette and Boerngen, 1984). Uranium concentrations in 9 of the 14 samples listed in table 23 exceeded the upper base line for uranium of $5.3 \mu \mathrm{g} / \mathrm{g}$ (Shacklette and Boerngen, 1984). The differences in uranium concentrations between pond bottom sediment and stream bottom sediment were considerably less than were the differences in selenium concentrations, especially in the Grand Valley (table 23). Molybdenum concentrations in three of the four bottom-sediment samples from ponds were slightly greater than the upper soils base line of $4 \mu \mathrm{g} / \mathrm{g}$. The salt-crust sample from Brozina Pond has unusually low concentrations of some trace constituents, such as barium, chromium, vanadium, and zinc, compared to bottom-sediment samples.

\section{BIOLOGICAL INVESTIGATIONS}

\section{Sample Collection}

Biological samples were collected by the FWS using standard equipment and techniques (U.S. Fish and Wildlife Service, 1986, 1990). Fish were collected using electroshocking equipment and seine or gill nets. Fish were rinsed, weighed, measured for length, and immediately frozen on dry ice until stored in a freezer. Whole-body fish samples from tributaries were composited by species into groups of three or more fish as directed by the sampling protocol. Fish samples from rivers were processed as individual samples for data-analysis purposes. Fish-fillet and -egg samples were taken from individual fish and were not composited. Fish samples for analyses of inorganic contaminants were frozen in plastic bags. Fish samples for analyses of organic compounds were wrapped in aluminum foil and placed in plastic bags.

Vascular plants and algae were collected by handpicking. These samples were placed in chemically cleansed jars, weighed, and frozen. Algae samples probably contained green algae (Chlorophyta) and blue-green algae (Cyanophyta). Stream invertebrates were collected using a kick screen. Several easily identifiable invertebrate groups were combined to obtain sufficient biomass for analysis. Crayfish were collected when present.

Birds were shot using steel shot, and livers were removed using stainless-steel dissecting equipment. Bird liver was considered to be the best organ for a general trace-element scan (Ohlendorf, 1993), although other tissues might be better indicators for specific elements (such as kidney for cadmium and bone for lead). Dissecting equipment was cleansed using water and soap and rinsed using distilled water and benzene prior to the removal of each liver. Bird livers and muscle tissue were placed in chemically cleansed jars, weighed, and frozen. Livers from each bird group were sometimes composited, which resulted in two or three livers constituting one sample.

After locating nests, bird eggs were removed, the egg volume was determined (by water displacement), and eggs were opened to examine embryos for possible developmental abnormalities. After examination, eggs were placed in chemically cleansed jars, weighed, and frozen. Small eggs, such as blackbird eggs, were composited to provide sufficient biomass for analysis. 
The sampling period depended on availability of bird eggs and prefledgling birds. Because prefledglings generally are confined to a local area until they fledge, trace elements and pesticides in their tissues are obtained from food and water in the area where the birds are reared. An attempt was made to collect prefledglings immediately before fledging because older birds would have been exposed to any contaminants present in the area for a longer time period than younger birds. Such collections were not always possible because of time limitations in the sampling effort and because of considerable predation on young birds. Although developmental abnormalities among embryos in bird eggs cannot be detected before the eggs have reached one-half term (Ohlendorf and others, 1986), eggs were collected as soon as they were discovered because of the high risk of predation. Therefore, early collection to ensure that representative egg samples were available for contaminant analysis often outweighed the loss of pathological information related to field observations.

Because of high predation rates on bird eggs and hatchlings, incubation studies were conducted. For the incubation study, eggs were collected in the field and placed into egg cartons with Kleenex tissues to keep the pointed end down (Stromberg, 1975; Brown, 1979). The egg cartons were kept cool during transportation to the laboratory. Usually, the eggs were transferred from egg cartons to trays with the small end down and incubated at a temperature of $99^{\circ} \mathrm{F}$ and at a relative humidity of 55 percent (Stromberg, 1975; Brown, 1979). Eggs were mechanically turned at 4-hour intervals. Eggs were candled and a hatching date was projected by using a field guide for incubation lengths for each species (Harrison, 1979). Newly hatched young were examined for external deformities. Eggs that failed to hatch within a few days of their hatching date were opened and examined. All incubated specimens were frozen and sent to the laboratory for trace-element analysis.

\section{Analytical Methods}

The quantitative analyses of trace constituents in biological samples were performed by the Environmental Trace Substances Research Center in Columbia, Mo. This laboratory was contracted by the FWS Patuxent Analytical Control
Facility in Laurel, Md. Biological samples were analyzed for selenium and selected trace constituents.

Analyses for most trace constituents in biota samples were performed using inductively coupled argon-plasma atomic-absorption spectrometry after complete digestion of the sample by strong acids. Analyses for selenium and arsenic in biota samples were performed using HGAAS, and analysis for mercury was performed using flameless cold-vapor atomic-absorption spectrometry.

Organochlorine pesticides were analyzed at Mississippi State University in Mississippi State, Miss. Methods consisted of solvent extraction and electron-capture gas chromatography. Polycyclic aromatic hydrocarbons (PAH's) were analyzed at Texas A\&M University in College Station, Tex. The quantitative analyses were performed by using a mass spectrometer detector in the selected ionmonitoring mode.

\section{Data Analysis}

Statistical analyses were conducted using a statistical software program called Statistical Analysis System (SAS Institute, 1982). Geometric mean, geometric deviation, maximum, and minimum concentrations were determined.

Fish data for the Gunnison, Uncompahgre, and Colorado Rivers were analyzed by using a General Linear Model (GLM) for unbalanced data. A two-way ANOVA and the Tukey-Kramer Honestly Significant Difference (HSD) (SAS Institute, 1982) were used to compare selenium residues in fish among the three rivers, among individual sites on the three rivers, and among three fish trophic groups.

\section{Data Interpretation}

Many chemical, physical, and biological factors affect the toxicity of environmental contaminants to biological organisms. Chemical and physical factors include contaminant type, chemical species or form, $\mathrm{pH}$, water temperature, dissolved oxygen, hardness, salinity, and multiple-chemical exposure (antagonism and synergism). Duration of exposure, quantity of contaminant, and exposure pathways from the environment to the organism also affect toxicity. Some trace constituents are beneficial to organisms 
at small concentrations, but can be toxic at larger concentrations. Biological and physiological factors affecting toxicity are species, age, sex, and health of the organism. Interpretation of contaminant concentrations in biota is difficult and complex and often might not be possible, using the data collected in field studies. One of the best methods for interpreting contaminant data is by comparison with data collected from other field studies and from laboratory studies.

Concentrations of inorganic trace constituents in biological samples are extremely variable. Traceconstituent data can be interpreted by comparison to available literature to determine if constituent concentrations in biota samples exceed concentrations that could be harmful to fish and wildlife or exceed guidelines for human consumption. A frequently used index for interpreting contaminant data for fish samples is the National Contaminant Biomonitoring Program (NCBP) of the FWS. Schmitt and Brumbaugh (1990) reported the 85th-percentile concentrations for arsenic, cadmium, copper, lead, mercury, selenium, and zinc for fish samples collected during 1976-84 throughout the United States. The 85 th percentile has been established by NCBP as an arbitrary concentration for distinguishing wholebody fish samples that have large concentrations for the seven trace constituents relative to a national data base. The 85 th percentile is not necessarily an indicator of potential hazards to fishery resources nor can it be used in place of regulatory standards. The NCBP means and percentiles were calculated using combined fish species, and readers need to be aware that there can be substantial differences in selenium accumulation between species (Lemly, 1993). Nevertheless, NCBP data still are useful for comparison purposes. Concentrations listed in Schmitt and Brumbaugh (1990) are wet-weight concentrations; therefore, the dry-weight concentrations for biota samples collected for the detailed study (Butler and others, 1994) for the seven trace constituents were converted to wet-weight concentrations to facilitate comparison to the 85th-percentile concentrations. The NCBP also has collected data for organochlorine pesticides (Schmitt and others, 1990).

The NCBP 85th percentile was reported for several periods within the sampling period (1976-84) (Schmitt and Brumbaugh, 1990). The most recent compilation was for fish samples collected during 1984 , and the 85th percentiles reported for 1984 are used in this report. The previous DOI reconnaissance investigations used 85th percentiles based on earlier compilation periods.

\section{Selenium Concentrations in Fish Samples and Their Food Items in Irrigated Areas}

\section{Uncompahgre Project}

In general, selenium concentrations were higher in biota samples collected east of the Uncompahgre River than in samples collected west of the Uncompahgre River (Butler and others, 1994, tables 23-27). This pattern in selenium data in biota was similar to the pattern in surface-water samples. Biota-sampling sites within the irrigated area east of the Uncompahgre River include sites DCC1, CD1, LZA1, and PVA1 (fig. 44), and west of the river include sites HFC, HCC1, SP1, SP4, DRY1, DRY5, CMG1, and RB1 (fig. 44). Aquatic-plant, aquaticinsect, and crayfish samples collected east of the Uncompahgre River from Loutsenhizer Arroyo (site LZA1 in fig. 44) contained 4.1, 26, and $12 \mu \mathrm{g} / \mathrm{g}$ dry weight selenium (Butler and others, 1994, table 24). An invertebrate sample from Peach Valley Arroyo (site PVA1 in fig. 44) contained $7.1 \mu \mathrm{g} / \mathrm{g}$ dry weight selenium. Lemly and Smith (1987) and Lemly (1993) recommended that $3 \mu \mathrm{g} / \mathrm{g}$ dry weight selenium be used as a toxic threshold guideline for selenium transferred to consumer species of fish and wildlife through aquatic food chains. The samples from Loutsenhizer and Peach Valley Arroyos exceeded this dietary guideline.

Eight plant and algae samples collected from the western side of the Uncompahgre River had a geometric mean selenium concentration of $1.0 \mu \mathrm{g} / \mathrm{g}$ dry weight (table 25), which is less than the dietary guideline. An aquatic-invertebrate sample collected from Horsefly Creek (site HFC in fig. 44) on the western side of the Uncompahgre River contained $6.1 \mu \mathrm{g} / \mathrm{g}$ dry weight selenium and exceeded the 3- $\mu \mathrm{g} / \mathrm{g}$ dry-weight dietary guideline. A crayfish sample collected from Happy Canyon Creek (site HCC1) contained $2.1 \mu \mathrm{g} / \mathrm{g}$ dry weight selenium. 

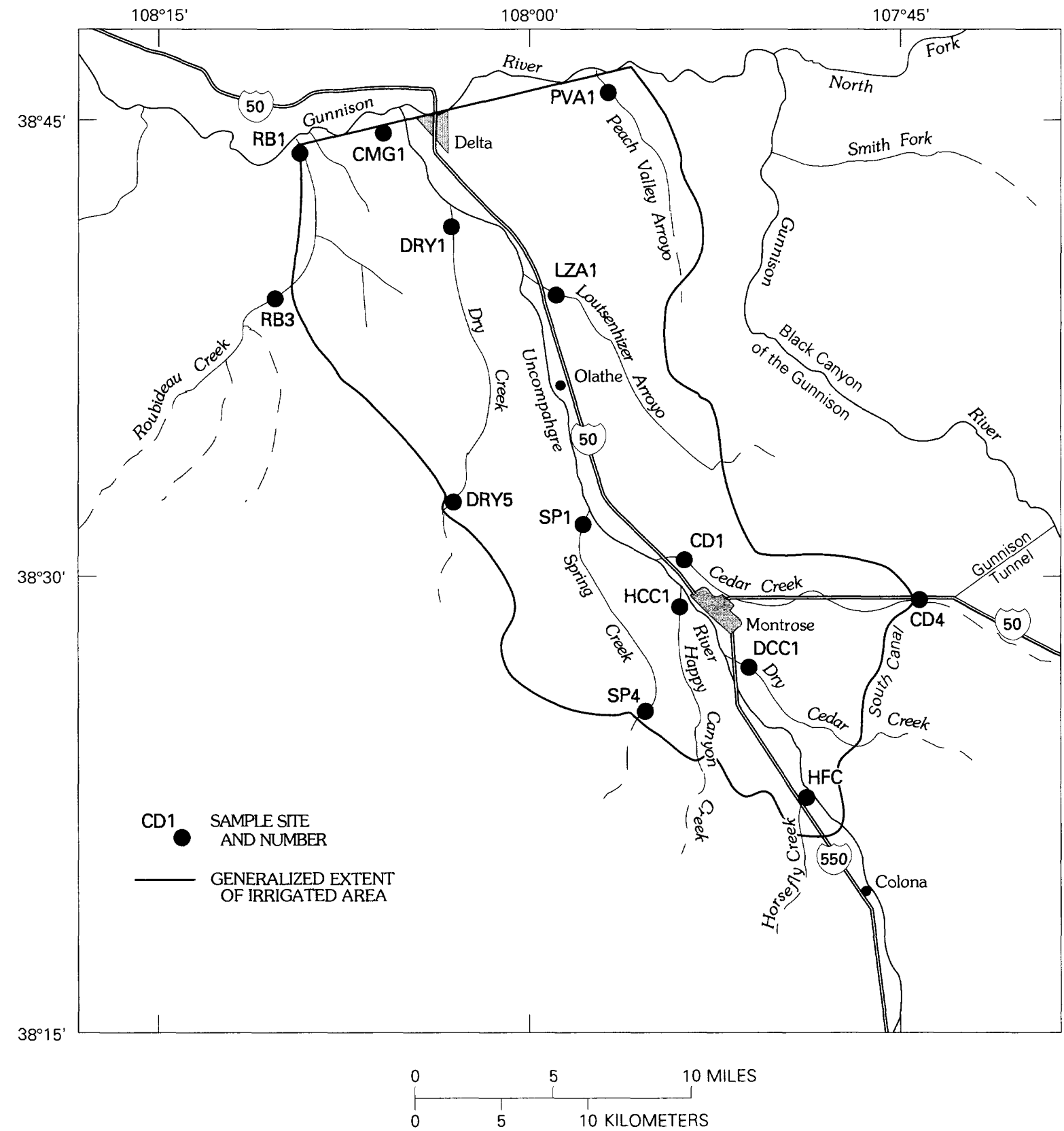

Figure 44. Location of 1991 biota sampling sites on tributary streams in the Uncompahgre Project.

All eight fish samples collected from streams on the eastern side of the Uncompahgre River exceeded the 1984 NCBP 85th-percentile selenium concentration (table 26) of $0.73 \mu \mathrm{g} / \mathrm{g}$ wet weight $(2.92 \mu \mathrm{g} / \mathrm{g}$ dry weight at 75 -percent moisture). Lemly (1993) advised that a whole-body selenium concentration of $4 \mu \mathrm{g} / \mathrm{g}$ dry weight or greater could be of concern for the overall health and reproductive vigor of freshwater fish. All fish samples collected east of the Uncompahgre River exceeded $4 \mu \mathrm{g} / \mathrm{g}$ dry weight selenium. Two speckled dace samples collected east of the Uncompahgre River (sites DCC1 and LZA1 in fig. 44) contained 27 and $28 \mu \mathrm{g} / \mathrm{g}$ dry weight selenium (table 25 ). A green sunfish collected from Loutsenhizer Arroyo (site LZA1) contained $37 \mu \mathrm{g} / \mathrm{g}$ dry weight selenium, which is noteworthy because centrarchids (the sunfish family) seem to be especially sensitive to selenium toxicity (Cumbie and Van Horn, 1978; Lemly, 1985). 
Table 25. Statistical summary of selenium concentrations in selected biota samples collected in 1991 in the Uncompahgre Project area

[Concentrations in micrograms per gram dry weight; N, number of samples; GM, geometric mean; GD, geometric deviation; --, no data or not computed; data for reference sites on Cedar Creek (CD4) and Roubideau Creek (RB3) were excluded]

\begin{tabular}{|c|c|c|c|c|c|c|c|}
\hline Statistic & $\begin{array}{l}\text { Aquatlc } \\
\text { plants } \\
\text { and } \\
\text { algae }\end{array}$ & $\begin{array}{c}\text { Aquatic } \\
\text { Invertebrates }\end{array}$ & $\begin{array}{l}\text { Speckled } \\
\text { dace }\end{array}$ & Suckers & $\begin{array}{l}\text { Roundtail } \\
\text { chub }\end{array}$ & Trout & $\begin{array}{l}\text { Groen } \\
\text { sunfish }\end{array}$ \\
\hline \multicolumn{8}{|c|}{ UNCOMPAHGRE PROJECT-EAST OF THE UNCOMPAHGRE RIVER } \\
\hline $\mathbf{N}$ & 1 & 3 & 2 & 5 & 0 & 0 & 1 \\
\hline GM & -- & 13 & 27.5 & 13.9 & -- & -- & -- \\
\hline GD & -- & 1.9 & 1.0 & 1.4 & -- & -- & -- \\
\hline MAXIMUM & 4.1 & 26 & 28 & 22 & - & -- & 37 \\
\hline MINIMUM & 4.1 & 7.1 & 27 & 9.0 & -- & -- & 37 \\
\hline \multicolumn{8}{|c|}{ UNCOMPAHGRE PROJECT - WEST OF THE UNCOMPAHGRE RIVER } \\
\hline $\mathbf{N}$ & 8 & 3 & 3 & 13 & 1 & 5 & $\mathbf{0}$ \\
\hline GM & 1.0 & 3.0 & 8.9 & 2.9 & - & 5.8 & -- \\
\hline GD & 2.3 & 1.9 & 1.5 & 1.6 & -- & 2.3 & -- \\
\hline MAXIMUM & 2.9 & 6.1 & 13 & 5.9 & 5.9 & 25 & -- \\
\hline MINIMUM & .2 & 2.1 & 5.6 & 1.2 & 5.9 & 3.4 & -- \\
\hline \multicolumn{8}{|c|}{ SMITH FORK AND NORTH FORK BASINS } \\
\hline $\mathbf{N}$ & 3 & 3 & 3 & 3 & 1 & 5 & 0 \\
\hline GM & 1.6 & 3.1 & 7.3 & 2.7 & -- & 5.8 & -- \\
\hline GD & 1.0 & 1.6 & 1.1 & 1.8 & - & 1.5 & - \\
\hline MAXIMUM & 1.6 & 4.8 & 7.8 & 3.9 & 6.1 & 9.4 & -- \\
\hline MINIMUM & 1.6 & 2.0 & 6.9 & 1.4 & 6.1 & 3.6 & -- \\
\hline \multicolumn{8}{|c|}{ CURRANT CREEK, ALFALFA RUN, AND TONGUE CREEK } \\
\hline $\mathbf{N}$ & 3 & 3 & 2 & 1 & 2 & $\mathbf{0}$ & 0 \\
\hline GM & 6.6 & 7.0 & 12.5 & -- & 13.8 & -- & -- \\
\hline GD & 1.7 & 1.4 & 1.1 & -- & 1.6 & -- & -- \\
\hline MAXIMUM & 12 & 9.4 & 13 & 12 & 19 & -- & -- \\
\hline MINIMUM & 4.1 & 4.9 & 12 & 12 & 10 & - & -- \\
\hline
\end{tabular}

Table 26. Number of whole-body fish samples collected in the Uncompahgre Project area that exceeded the 1984 National Contaminant Biomonitoring Program (NCBP) 85th-percentile concentrations for seven trace constituents

[NCBP 85th-percentile concentrations in micrograms per gram wet weight; NCBP data from Schmitt and Brumbaugh (1990); east, samples from eastern side of the Uncompahgre Project; west, samples from the western side of the Uncompahgre Project; adjacent 1 , samples from the Smith Fork and North Fork Basins; adjacent 2, samples from Currant Creek, Alfalfa Run, and Tongue Creek; N, number of samples; numbers in brackets are the number of exceedances expressed as a percentage of the number of samples in each group]

\begin{tabular}{lclcccc}
\hline $\begin{array}{c}\text { Trace } \\
\text { constituent }\end{array}$ & $\begin{array}{c}\text { NCBP } \\
\mathbf{8 5 t h} \\
\text { percentile }\end{array}$ & $\begin{array}{c}\text { East } \\
\mathbf{( N = 8 )}\end{array}$ & $\begin{array}{c}\text { West } \\
\mathbf{( N = 2 9 )}\end{array}$ & $\begin{array}{c}\text { Adjacent 1 } \\
(\mathbf{N}=15)\end{array}$ & $\begin{array}{c}\text { Adjacent 2 } \\
(\mathbf{N}=8)\end{array}$ & $\begin{array}{c}\text { Crawford } \\
\text { Reservoir } \\
(\mathbf{N}=5)\end{array}$ \\
\hline Arsenic & 0.27 & $0[0]$ & $4[14]$ & $1[7]$ & $1[12]$ & $1[20]$ \\
Cadmium & .05 & $3[38]$ & $7[24]$ & $3[20]$ & $0[0]$ & $0[0]$ \\
Copper & 1.0 & $5[62]$ & $19[66]$ & $5[33]$ & $4[50]$ & $2[20]$ \\
Lead $^{1}$ & .22 & $2[25]$ & $9[31]$ & $0[0]$ & $0[0]$ & $0[0]$ \\
Mercury & .17 & $0[0]$ & $4[14]$ & $0[0]$ & $0[0]$ & $0[0]$ \\
Selenium & .73 & $8[100]$ & $22[76]$ & $14[93]$ & $8[100]$ & $4[80]$ \\
Zinc & 34.2 & $3[38]$ & $5[17]$ & $3[20]$ & $3[38]$ & $0[0]$ \\
\hline
\end{tabular}

${ }^{1}$ Some samples had reporting limits greater than the 1984 NCBP 85 th percentile. 
Twenty-two of 29 fish samples collected on the western side of the Uncompahgre Project exceeded the 1984 NCBP 85th-percentile selenium concentration (table 26). Eight of these 22 samples were collected from Dry Creek. One trout sample collected at site DRY1 from lower Dry Creek contained $25 \mu \mathrm{g} / \mathrm{g}$ dry weight selenium. Relatively high selenium concentrations also were in surface-water samples collected from lower Dry Creek compared to the other major streams on the western side, and these concentrations are partly attributed to the transport of water from the Uncompahgre River by the Ironstone Canal into the lower Dry Creek Basin. Two trout liver samples collected west of the Uncompahgre River (sites HCC1 and SP1 in fig. 44) contained 110 and $180 \mu \mathrm{g} / \mathrm{g}$ dry weight selenium. These concentrations were much greater than a guideline concentration of $12 \mu \mathrm{g} / \mathrm{g}$ dry weight selenium in fish livers (Lemly, 1993). Liver tissue often accumulates the greatest amount of selenium (Sager and Cofield, 1984), and concentrations in liver tissue might be useful in assessing recent exposure (Ohlendorf, 1993).

All selenium concentrations in aquatic-plant and -invertebrate samples collected in tributaries downstream from the confluence of the Uncompahgre and Gunnison Rivers (Butler and others, 1994, table 27) were less than the dietary guideline of $3 \mu \mathrm{g} / \mathrm{g}$ dry weight (Lemly and Smith, 1987; Lemly 1993). Ten of 13 whole-body fish samples exceeded the 1984 NCBP 85th-percentile concentration of $2.9 \mu \mathrm{g} / \mathrm{g}$ dry weight (at 75-percent moisture), and 9 of these samples exceeded the 4- $\mu \mathrm{g} / \mathrm{g}$ selenium concentration of concern for reproductive problems in whole-body fish (Lemly, 1993). Highest selenium concentrations were in fish collected from Cummings Gulch (site CMG1 in fig. 44); a trout fillet contained $9.9 \mu \mathrm{g} / \mathrm{g}$ dry weight selenium, a whole-body speckled dace sample contained $13 \mu \mathrm{g} / \mathrm{g}$ dry weight selenium, and a whole-body carp sample contained $12 \mu \mathrm{g} / \mathrm{g}$ dry weight selenium (Butler and others, 1994, table 27).

The geometric mean selenium concentration for five sucker samples collected on the eastern side of the Uncompahgre Project was $13.9 \mu \mathrm{g} / \mathrm{g}$ dry weight (table 25). Two composite sucker samples from site CD4 (fig. 44), a reference site on Cedar Creek, contained 6.1 and $4.7 \mu \mathrm{g} / \mathrm{g}$ dry weight selenium. One composite sucker sample collected at site CD1, near the mouth of Cedar Creek, contained almost twice as much selenium $(12 \mu \mathrm{g} / \mathrm{g}$ dry weight selenium) as the sucker samples from site CD4 (Butler and others, 1994, table 24). The geometric mean selenium concentration for 13 sucker samples collected west of the Uncompahgre River was only $2.9 \mu \mathrm{g} / \mathrm{g}$ dry weight (table 25 ). Selenium concentrations in sucker samples from site RB3 (a reference site on Roubideau Creek) (fig. 44) contained 1.3 and $2.9 \mu \mathrm{g} / \mathrm{g}$ dry weight selenium. Selenium concentrations downstream at site RB 1 on Roubideau Creek (fig. 44) were slightly higher than the concentrations at site RB3 at 2.2 and $4.6 \mu \mathrm{g} / \mathrm{g}$ dry weight. Selenium concentrations in roundtail chub samples also were similar between the sites on Roubideau Creek; the samples collected from site RB1 contained $5.9 \mu \mathrm{g} / \mathrm{g}$ dry weight selenium, and those collected from site RB3 contained $5.4 \mu \mathrm{g} / \mathrm{g}$ dry weight selenium. Two speckled dace samples collected from the eastern side of the project had selenium concentrations of 27 and $28 \mu \mathrm{g} / \mathrm{g}$ dry weight, whereas three speckled dace samples collected on the western side had a geometric mean of $8.9 \mu \mathrm{g} / \mathrm{g}$ dry weight selenium.

\section{Areas Adjacent to the Uncompahgre Project}

Most biota samples (especially fish) collected from areas adjacent to the Uncompahgre Project also had high selenium concentrations. Data for adjacent sites (fig. 45) were collected in the Smith Fork (site SMF) and North Fork (sites NFK2 and NFK3) of the Gunnison River, plus Crawford Reservoir (site CR) (located on the Smith Fork). Data for adjacent sites also include samples collected from the Gunnison River at site GUN2 and its tributaries between the confluence with the North Fork and the confluence with the Uncompahgre River (sites CRC, AFR, and TGC in fig. 45). Geometric mean selenium concentrations for biota collected from sites adjacent to the Uncompahgre Project are listed in table 25.

Almost all whole-body fish samples from the Smith Fork, the North Fork of the Gunnison River, and Crawford Reservoir had selenium concentrations that exceeded the 1984 NCBP 85th-percentile concentration of $0.73 \mu \mathrm{g} / \mathrm{g}$ wet weight (table 26), and many concentrations exceeded the $4-\mu \mathrm{g} / \mathrm{g}$ dry-weight selenium concentration of concern for whole-body fish (Lemly, 1993). One whole-body trout sample collected from Crawford Reservoir (site CR in fig. 45) contained $18 \mu \mathrm{g} / \mathrm{g}$ dry weight selenium. 


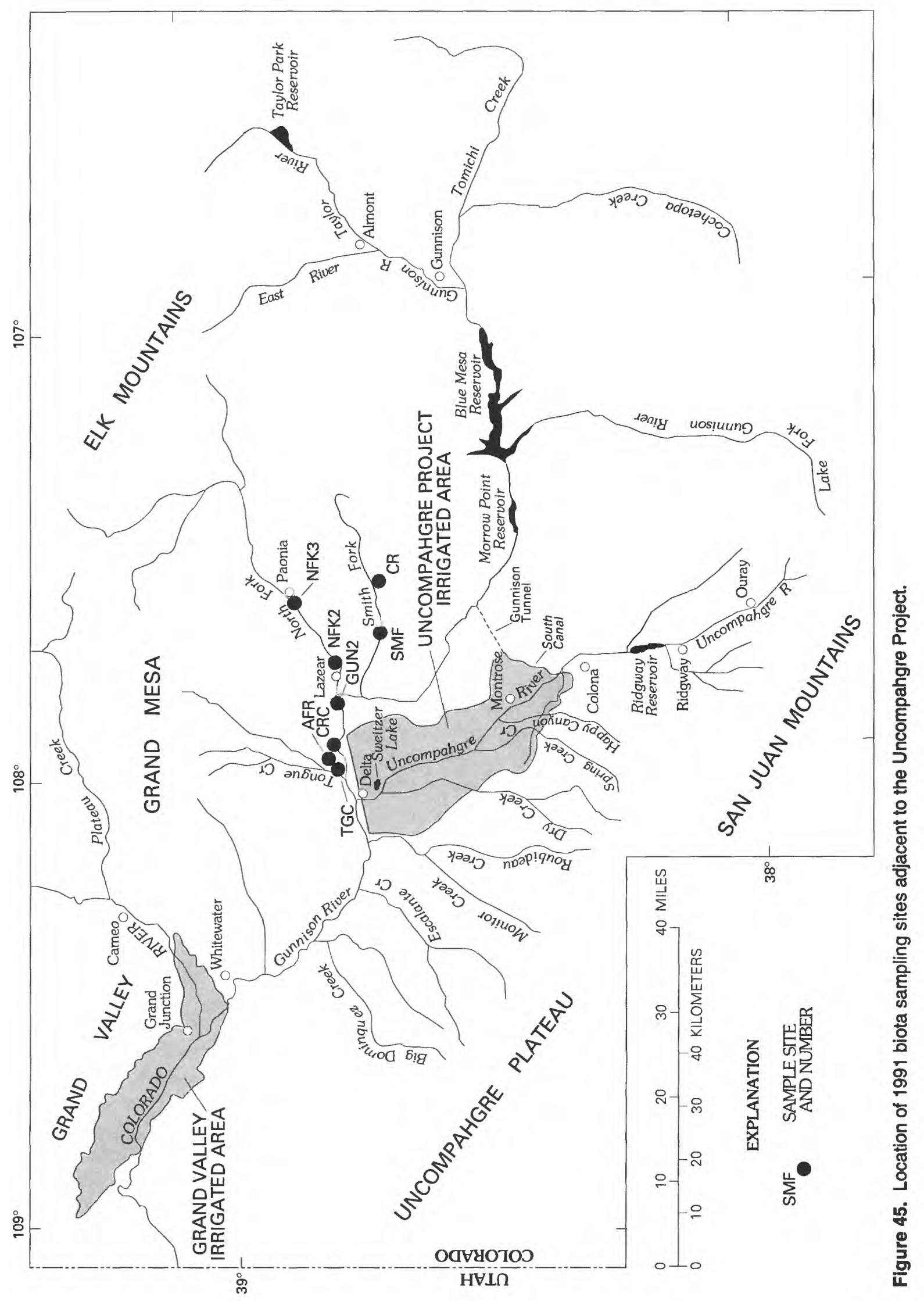


A whole-body perch sample collected from Crawford Reservoir (site CR) contained $11 \mu \mathrm{g} / \mathrm{g}$ dry weight selenium, which is slightly less than the concentration of $12 \mu \mathrm{g} / \mathrm{g}$ dry weight selenium that Lemly and Smith (1987) warned could cause reproductive failure in warmwater fishes. A fillet sample taken from a yellow perch collected from Crawford Reservoir (site CR) contained $16 \mu \mathrm{g} / \mathrm{g}$ dry weight selenium, which exceeded the concentration of concern of $8 \mu \mathrm{g} / \mathrm{g}$ dry weight selenium for fish-fillet samples (Lemly, 1993). Although centrarchids (perch and sunfish) seem to be especially sensitive to selenium (Cumbie and Van Horn, 1978; Lemly, 1985), the yellow perch population in Crawford Reservoir is thriving with good reproduction.

Two fish-liver samples taken from a trout (site SMF in fig. 45) and a catfish (site CR) either equaled or exceeded the concentration of concern for fish livers of $12 \mu \mathrm{g} / \mathrm{g}$ dry weight (Lemly, 1993). An egg sample from a trout (site SMF) contained $31 \mu \mathrm{g} / \mathrm{g}$ dry weight selenium, which exceeded the concentration of concern of $10 \mu \mathrm{g} / \mathrm{g}$ dry weight selenium in fish eggs (Lemly, 1993). The high selenium concentrations in biota collected from site SMF are noteworthy because selenium was not detected in the surfacewater sample collected in July 1991.

Selenium concentrations in biota samples collected from the Gunnison River (site GUN2) and the three tributaries (sites CRC, AFR, and TGC in fig. 45) also were elevated (table 25). Selenium concentrations in all six dietary items (aquatic plants and invertebrates) from the three tributary sites exceeded the dietary guideline of $3 \mu \mathrm{g} / \mathrm{g}$ dry weight (Lemly and Smith, 1987; Lemly, 1993). All wholebody fish samples collected from the three tributary sites exceeded the 1984 NCBP 85 th-percentile concentration (table 26) and exceeded the $4-\mu \mathrm{g} / \mathrm{g}$ dry-weight concentration of concern for whole-body fish (Lemly, 1993). Six whole-body fish samples collected from Currant Creek (site CRC), Alfalfa Run (site AFR), and the Gunnison River (site GUN2) (Butler and others, 1994, table 26) equaled or exceeded $12 \mu \mathrm{g} / \mathrm{g}$ dry weight selenium, which is the concentration that Lemly and Smith (1987) warned might cause reproductive problems in warmwater fish. Selenium concentrations in fathead minnow wholebody samples from three sites (sites GUN2, CRC, and TGC) ranged from 7.5 to $20.4 \mu \mathrm{g} / \mathrm{g}$ dry weight, exceeding known toxicity concentrations for fathead minnows. Ogle and Knight (1989) reported that a whole-body selenium concentration of $6 \mu \mathrm{g} / \mathrm{g}$ dry weight slowed growth in juvenile and adult fathead minnows. Schultz and Hermanutz (1990) reported reproductive failure in fish that had a wholebody selenium concentration of $8 \mu \mathrm{g} / \mathrm{g}$ dry weight. Although the selenium concentrations in biota samples collected from Alfalfa Run (site AFR) were high, selenium was not detected in the single surface-water sample collected at site AFR in July 1991.

\section{Grand Valley}

Although variable, high selenium concentrations were reported in most Grand Valley biota samples (Butler and others, 1994, tables 28-30), which is not surprising because most selenium concentrations in surface-water samples often exceeded the chronic aquatic-life criterion, and many selenium concentrations in water samples exceeded the acute criterion during the nonirrigation season. Biota sampling sites on streams in the Grand Valley are shown in figure 46. Statistical summaries of selenium concentrations in aquatic plants, crayfish, and selected species of whole-body fish are listed in table 27. The summary data in table 27 does not include composite invertebrate samples nor does it include all fish species.

Three aquatic-plant samples were collected in Colorado River tributaries in the east Grand Valley, upstream from the Gunnison River confluence, and had a geometric mean selenium concentration of $4.1 \mu \mathrm{g} / \mathrm{g}$ dry weight (table 27). Selenium concentrations in two of the three plant samples from sites IW and OM2 (fig. 46) exceeded the toxicity guideline of $3 \mu \mathrm{g} / \mathrm{g}$ dry weight (Lemly and Smith, 1987; Lemly, 1993). The geometric mean selenium concentration for five invertebrate samples (including crayfish) collected in the east Grand Valley was $5.5 \mu \mathrm{g} / \mathrm{g}$ dry weight, and concentrations in three of the five invertebrate samples from sites IW and OMD (fig. 46) exceeded the guideline of $3 \mu \mathrm{g} / \mathrm{g}$ dry weight selenium. All 15 fish samples collected in the east Grand Valley tributaries contained selenium concentrations that exceeded the 1984 NCBP 85th-percentile concentration of $0.73 \mu \mathrm{g} / \mathrm{g}$ wet weight (table 28) and exceeded the whole-body concentration of $4 \mu \mathrm{g} / \mathrm{g}$ dry weight that could be of concern for the overall health and reproductive vigor of freshwater fish. The highest selenium concentration in a fish sample was $19 \mu \mathrm{g} / \mathrm{g}$ dry weight in a red shiner collected from Lewis Wash (site LW in fig. 46). 


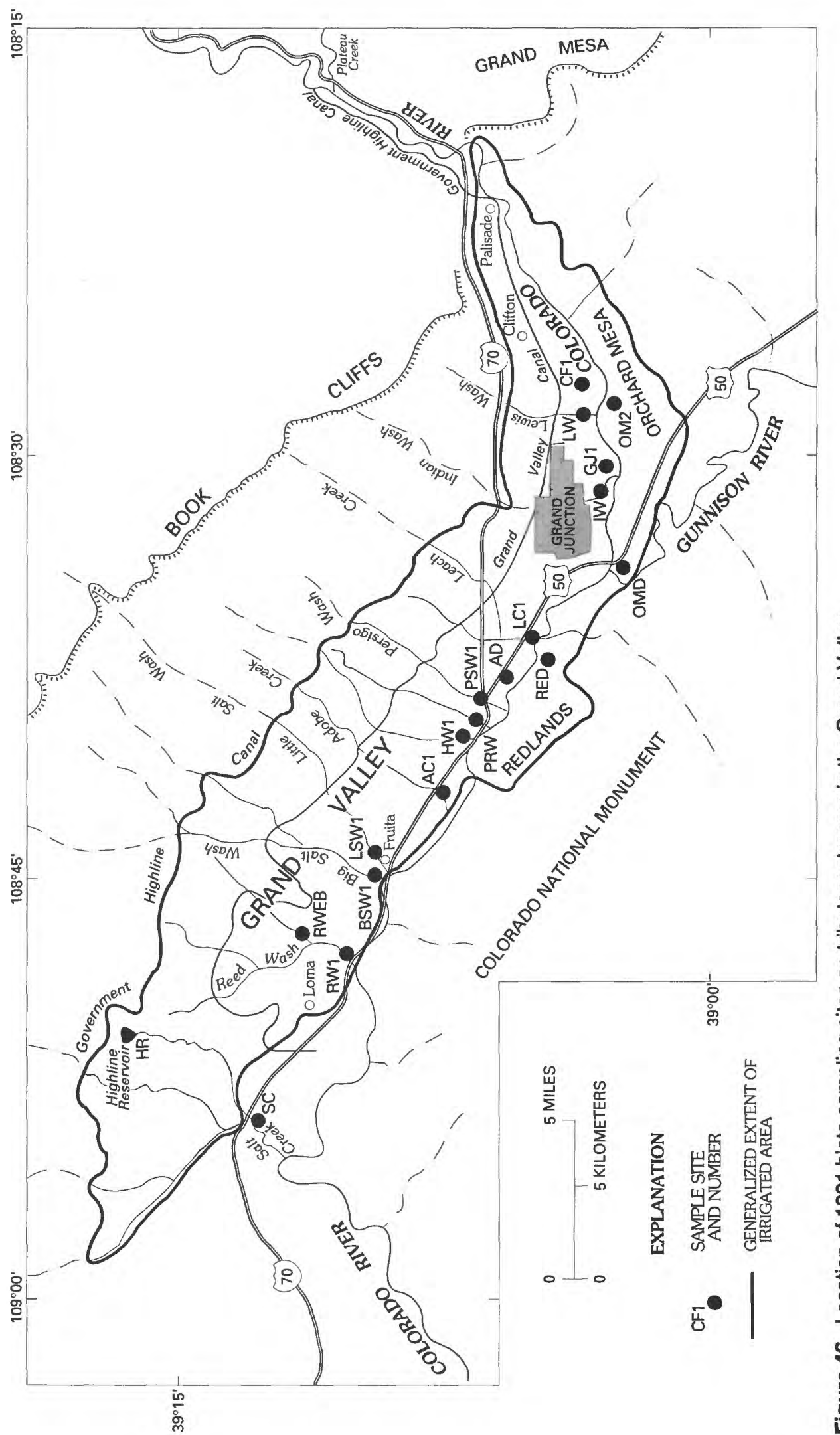

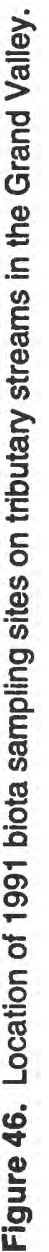


The selenium concentrations in fathead minnow whole-body samples ranged from 7.9 at site CF1 to $13 \mu \mathrm{g} / \mathrm{g}$ dry weight at site OMD (table 27 ) and exceeded known toxicity concentrations of $6 \mu \mathrm{g} / \mathrm{g}$ dry weight selenium for fathead minnows (Ogle and Knight, 1989; Schultz and Hermanutz, 1990).

Four aquatic-plant samples collected in the middle Grand Valley from tributaries of the Colorado River between the Gunnison River confluence and the town of Fruita (fig. 46) had a geometric mean selenium concentration of $1.8 \mu \mathrm{g} / \mathrm{g}$ dry weight (table 27). The selenium concentration of $7.0 \mu \mathrm{g} / \mathrm{g}$ dry weight from site RED (fig. 46) was the only plant sample that had a selenium concentration that exceeded the dietary guideline of $3 \mu \mathrm{g} / \mathrm{g}$ dry weight selenium for fish and wildlife (Lemly and Smith,
1987; Lemly 1993). A crayfish sample from Pritchard Wash at site PRW (fig. 46) containing $6.2 \mu \mathrm{g} / \mathrm{g}$ dry weight selenium was the only one of three invertebrate samples collected from Colorado River tributaries in the middle Grand Valley that exceeded the dietary guideline of $3 \mu \mathrm{g} / \mathrm{g}$ dry weight selenium. All $23 \mathrm{fish}$ samples collected in tributary streams in the middle Grand Valley contained selenium concentrations that exceeded the 1984 NCBP 85th-percentile concentration of $0.73 \mu \mathrm{g} / \mathrm{g}$ wet weight (table 28) (Schmitt and Brumbaugh, 1990) and all but one sample exceeded the whole-body concentration of concern of $4 \mu \mathrm{g} / \mathrm{g}$ dry weight (Lemly and Smith, 1987; Lemly, 1993). Selenium concentrations in whole-body fathead minnows in the middle Grand Valley ranged from $8 \mu \mathrm{g} / \mathrm{g}$ dry weight (site LC1 in fig. 46 ) to $22 \mu \mathrm{g} / \mathrm{g}$

Table 27. Statistical summary of selenium concentrations in selected biota samples collected during 1991 from the Grand Valley

[Concentrations in micrograms per gram dry weight; N, number of samples; GM, geometric mean; GD, geometric deviation; --, no data];

\begin{tabular}{|c|c|c|c|c|c|c|c|c|}
\hline Statistic & $\begin{array}{c}\text { Aquatic } \\
\text { plants } \\
\text { and } \\
\text { algae }\end{array}$ & Crayfish & $\begin{array}{l}\text { Speckled } \\
\text { dace }\end{array}$ & $\begin{array}{l}\text { Fathead } \\
\text { minnows }\end{array}$ & Suckers & Carp & $\begin{array}{l}\text { Roundtail } \\
\text { chub }\end{array}$ & $\begin{array}{l}\text { Channel } \\
\text { catfish }\end{array}$ \\
\hline \multicolumn{9}{|c|}{ EAST GRAND VALLEY-UPSTREAM FROM THE GUNNISON RIVER } \\
\hline $\mathrm{N}$ & 3 & 4 & 3 & 5 & 1 & 0 & 2 & 0 \\
\hline GM & 4.1 & 4.6 & 7.2 & 10.1 & - & - & 6.5 & - \\
\hline GD & 2.1 & 1.5 & 1.3 & 1.2 & -- & - & 2.8 & -- \\
\hline MAXIMUM & 7.5 & 7.3 & 10 & 13 & 9.7 & -- & 8.5 & -- \\
\hline MINIMUM & 1.8 & 3.0 & 6.1 & 7.9 & 9.7 & - & 4.5 & -- \\
\hline \multicolumn{9}{|c|}{ MIDDLE GRAND VALLEY-BETWEEN THE GUNNISON RIVER AND FRUITA } \\
\hline $\mathrm{N}$ & 4 & 3 & 1 & 5 & 6 & 0 & 5 & 0 \\
\hline GM & 1.8 & 4.0 & - & 13.2 & 7.8 & - & 7.6 & - \\
\hline GD & 2.6 & 1.5 & - & 1.5 & 1.4 & - & 1.1 & - \\
\hline MAXIMUM & 7.0 & 6.2 & 13 & 22 & 10 & - & 8.4 & - \\
\hline MINIMUM & .8 & 2.7 & 13 & 8.0 & 3.9 & -- & 6.8 & -- \\
\hline \multicolumn{9}{|c|}{ WEST GRAND VALLEY－FROM FRUITA TO SALT CREEK (STREAMS) } \\
\hline $\mathrm{N}$ & 0 & 2 & 3 & 1 & 10 & 0 & 4 & 0 \\
\hline GM & - & 4.4 & 13.4 & - & 9.2 & -- & 8.6 & - \\
\hline GD & - & 1.2 & 1.5 & -- & 1.7 & -- & 1.4 & -- \\
\hline MAXIMUM & - & 5.0 & 19 & 7.3 & 19 & - & 12 & -- \\
\hline MINIMUM & - & 3.9 & 8.3 & 7.3 & 3.3 & - & 5.8 & -- \\
\hline \multicolumn{9}{|c|}{ HIGHLINE RESERVOIR } \\
\hline$N$ & 0 & 0 & 0 & 0 & 1 & 2 & 0 & 2 \\
\hline GM & - & -- & - & - & - & 9.2 & -- & 5.5 \\
\hline GD & - & -- & - & -- & - & 1.1 & -- & 1.2 \\
\hline MAXIMUM & - & - & - & - & 15 & 10 & - & 6.2 \\
\hline MINIMUM & - & -- & - & -- & 15 & 8.4 & -- & 4.9 \\
\hline
\end{tabular}


Table 28. Number of whole-body fish samples collected in the Grand Valley that exceeded the 1984 National Contaminant Biomonitoring Program (NCBP) 85th-percentile concentrations for seven trace constituents

[NCBP 85th-percentile concentrations in micrograms per gram wet weight; NCBP data from Schmitt and Brumbaugh (1990); east, samples from tributary streams located upstream from the Gunnison River; middle, samples from streams located between the Gunnison River and Fruita; west, samples from streams located from Fruita to Salt Creek; all, all samples, excluding Highline Reservoir; N, number of samples; numbers in brackets are the number of exceedances expressed as a percentage of the number of samples in each group]

\begin{tabular}{lcccccc}
\hline $\begin{array}{c}\text { Trace } \\
\text { constituent }\end{array}$ & $\begin{array}{c}\text { NCBP } \\
\mathbf{8 5 t h} \\
\text { percentlle }\end{array}$ & $\begin{array}{c}\text { East } \\
\mathbf{N}=\mathbf{1 5})\end{array}$ & $\begin{array}{c}\text { Middle } \\
(\mathbf{N}=\mathbf{2 3})\end{array}$ & $\begin{array}{c}\text { West } \\
(\mathbf{N}=\mathbf{2 2})\end{array}$ & $\begin{array}{c}\text { All } \\
(\mathbf{N}=60)\end{array}$ & $\begin{array}{c}\text { Highline } \\
\text { Reservoir } \\
(\mathbf{N}=7)\end{array}$ \\
\hline Arsenic & 0.27 & $0[0]$ & $1[4]$ & $1[4]$ & $2[3]$ & $1[20]$ \\
Cadmium & .05 & $2[13]$ & $2[9]$ & $8[36]$ & $12[20]$ & $2[29]$ \\
Copper & 1.0 & $9[60]$ & $11[48]$ & $11[50]$ & $31[52]$ & $3[43]$ \\
Lead & .22 & $3[20]$ & $4[17]$ & $7[32]$ & $14[23]$ & $2[29]$ \\
Mercury & .17 & $0[0]$ & $0[0]$ & $0[0]$ & $0[0]$ & $0[0]$ \\
Selenium & .73 & $15[100]$ & $23[100]$ & $22[100]$ & $60[100]$ & $7[100]$ \\
Zinc & 34.2 & $11[73]$ & $10[44]$ & $5[23]$ & $26[43]$ & $2[29]$ \\
\hline
\end{tabular}

dry weight (site PSW1) (table 27) and exceeded known toxicity concentrations to fathead minnows of $6 \mu \mathrm{g} / \mathrm{g}$ dry weight (Ogle and Knight, 1989; Schultz and Hermanutz, 1990).

No aquatic-plant samples were collected in the west Grand Valley from tributary streams of the Colorado River between Fruita and Salt Creek. One of two invertebrate samples (table 27), a crayfish sample containing $5 \mu \mathrm{g} / \mathrm{g}$ dry weight selenium from Big Salt Wash (site BSW1 in fig. 46), exceeded the dietary guideline of $3 \mu \mathrm{g} / \mathrm{g}$ dry weight (Lemly and Smith, 1987; Lemly, 1993). All of the 22 whole-body fish samples collected from tributaries in the west Grand Valley, plus 7 whole-body fish samples collected from Highline Reservoir (site HR in fig. 46), contained selenium concentrations that exceeded the 1984 NCBP 85th-percentile concentration (table 28) and most concentrations also exceeded the concentration of concern of $4 \mu \mathrm{g} / \mathrm{g}$ dry weight for whole-body fish (Lemly and Smith, 1987; Lemly 1993). The highest selenium concentrations in fish collected in the west Grand Valley were in sucker and speckled dace samples collected from Salt Creek (site SC in fig. 46), which contained $19 \mu \mathrm{g} / \mathrm{g}$ dry weight selenium (table 27). Egg and liver tissues were dissected from a catfish collected from Highline Reservoir; the egg sample contained $11 \mu \mathrm{g} / \mathrm{g}$ dry weight selenium and the liver sample contained $16 \mu \mathrm{g} / \mathrm{g}$ dry weight selenium (Butler and others, 1994, table 28). Lemly (1993) stated that $12 \mu \mathrm{g} / \mathrm{g}$ dry weight selenium in liver tissue and $10 \mu \mathrm{g} / \mathrm{g}$ dry weight selenium in ovary and egg tissue are biological-effect thresholds for the health and reproductive success of freshwater anadromous fish. The selenium concentrations in the catfish tissue samples from Highline Reservoir exceeded these guidelines.

Sample sizes for each biota group were too small to use statistical analysis to compare the three areas of the Grand Valley, but there was a general increase in selenium in roundtail chubs and speckled dace samples in a downstream direction (east to west) in the Grand Valley (table 27). Only one sucker sample was collected in the east Grand Valley, and it contained $9.7 \mu \mathrm{g} / \mathrm{g}$ dry weight selenium. The geometric mean selenium concentration for sucker samples from the middle Grand Valley was $7.8 \mu \mathrm{g} / \mathrm{g}$ dry weight, and for the west Grand Valley was $9.2 \mu \mathrm{g} / \mathrm{g}$ dry weight (table 27). The geometric mean selenium concentration for speckled dace from the east Grand Valley was $7.2 \mu \mathrm{g} / \mathrm{g}$ dry weight; the concentration in the one speckled dace sample from the middle Grand Valley was $13 \mu \mathrm{g} / \mathrm{g}$ dry weight; and the mean concentration for speckled dace from the west Grand Valley was $13.4 \mu \mathrm{g} / \mathrm{g}$ dry weight. Fish samples collected from Salt Creek and Reed Wash (fig. 46), which drain much of the west part of the Grand Valley, contained consistently high selenium concentrations. The highest median selenium concentrations in surface-water samples from the Grand Valley also were for the Salt Creek and Reed Wash basins. 


\section{Selenium Concentrations in Fish Samples from Mainstem Rivers}

Beginning in March 1992, before snowmelt and irrigation began, fish samples were collected from 11 locations on the Colorado, Gunnison, and Uncompahgre Rivers (fig. 47). One of the sampling sites for the Gunnison River was on the North Fork at site NFK2 (fig. 47), the other 10 sites were on the three mainstem rivers. Sample locations were selected to include river sections that receive major selenium loading and could be subject to effects of selenium bioaccumulation. The sampling of mainstem rivers was designed to collect 10 suckers, 10 speckled dace, and 10 roundtail chubs from each of the 11 sampling sites; however, not all 3 species were present at each site. Those three fish species represent three trophic levels of species that are abundant in the study area.

For all fish species, the 112 fish collected from the Gunnison River had an arithmetic mean selenium concentration of $7.1 \mu \mathrm{g} / \mathrm{g}$ dry weight, which was significantly higher than the arithmetic mean selenium concentrations for the Colorado and Uncompahgre Rivers [significance level (p) less than or equal to 0.05 ]. The mean selenium concentration for 120 fish collected from the Colorado River was $4.6 \mu \mathrm{g} / \mathrm{g}$ dry weight, and for 64 fish collected from the Uncompahgre River, the mean was $5.1 \mu \mathrm{g} / \mathrm{g}$ dry weight. The mean selenium concentrations for fish from the Uncompahgre River and the Colorado River are not significantly different ( $p$ less than 0.05 ). Mean selenium concentrations for whole-body fish samples collected from each of the three river basins exceeded the concentration of concern of $4 \mu \mathrm{g} / \mathrm{g}$ dry weight selenium for whole-body fish (Lemly, 1993). The mean selenium concentrations for the fish groups are shown in figure 48. Mean selenium concentrations for roundtail chubs, suckers, and speckled dace were highest for the Gunnison River (significantly greater for speckled dace; $p$ less than 0.05). Mean selenium concentrations in those three fish-trophic groups were lowest for the Colorado River (significantly so for suckers; $p$ less than 0.05 ). Of the whole-body fish samples from the Gunnison River collected in 1992, about 96 percent exceeded the 1984 NCBP 85 th-percentile concentration for selenium (table 29) and about 71 percent exceeded the selenium concentration of concern of $4 \mu \mathrm{g} / \mathrm{g}$ dry weight for whole-body fish (Lemly, 1993). About 80 percent of the whole-body fish samples from the Colorado River and the Uncompahgre River exceeded the 1984 NCBP 85th percentile. Fifty-five percent of Colorado River whole-body fish samples and 64 percent of Uncompahgre River whole-body fish samples had selenium concentrations that exceeded the concentration of concern of $4 \mu \mathrm{g} / \mathrm{g}$ dry weight (Lemly, 1993).

Differences in selenium concentrations among fish species were significant. Speckled dace contained significantly higher selenium concentrations than the other fish species (p-value of 0.05 ). When data for all sites were combined, the mean selenium concentration for 105 speckled dace was $8.3 \mu \mathrm{g} / \mathrm{g}$ dry weight. The mean selenium concentration was $5.8 \mu \mathrm{g} / \mathrm{g}$ dry weight in 71 roundtail chubs; $4.7 \mu \mathrm{g} / \mathrm{g}$ dry weight in 10 mottled sculpins; and $3.1 \mu \mathrm{g} / \mathrm{g}$ dry weight in 110 suckers. These mean selenium concentrations are all significantly different ( $p$-value less than 0.05 ). Species differences accounted for almost 50 percent of the variance in the sum of squares using ANOVA ( $p$-value equal to 0.0001).

Selenium concentrations in whole-body fish were compared between individual sites for each of the three rivers. Mean selenium concentrations for fish representing three fish trophic groups collected from four Colorado River sites are shown in figure 49. Mean selenium concentrations for suckers collected from the Colorado River indicate a trend of increasing concentrations in a downstream direction. The mean selenium concentration for suckers from the most upstream site (COL1 in fig. 47) was significantly less than the mean selenium concentrations of suckers collected from the lower three sites (fig. 49). In contrast, speckled dace collected from site COL1 contained a higher mean selenium concentration than speckled dace from the lower three sites (fig. 49) and was significantly greater than the mean selenium concentration in speckled dace collected from site COL4. Mean selenium concentrations in roundtail chubs collected from the Colorado River sites were not significantly different ( $p$-value of 0.05 ), but do have a trend of increasing concentration in a downstream direction. 


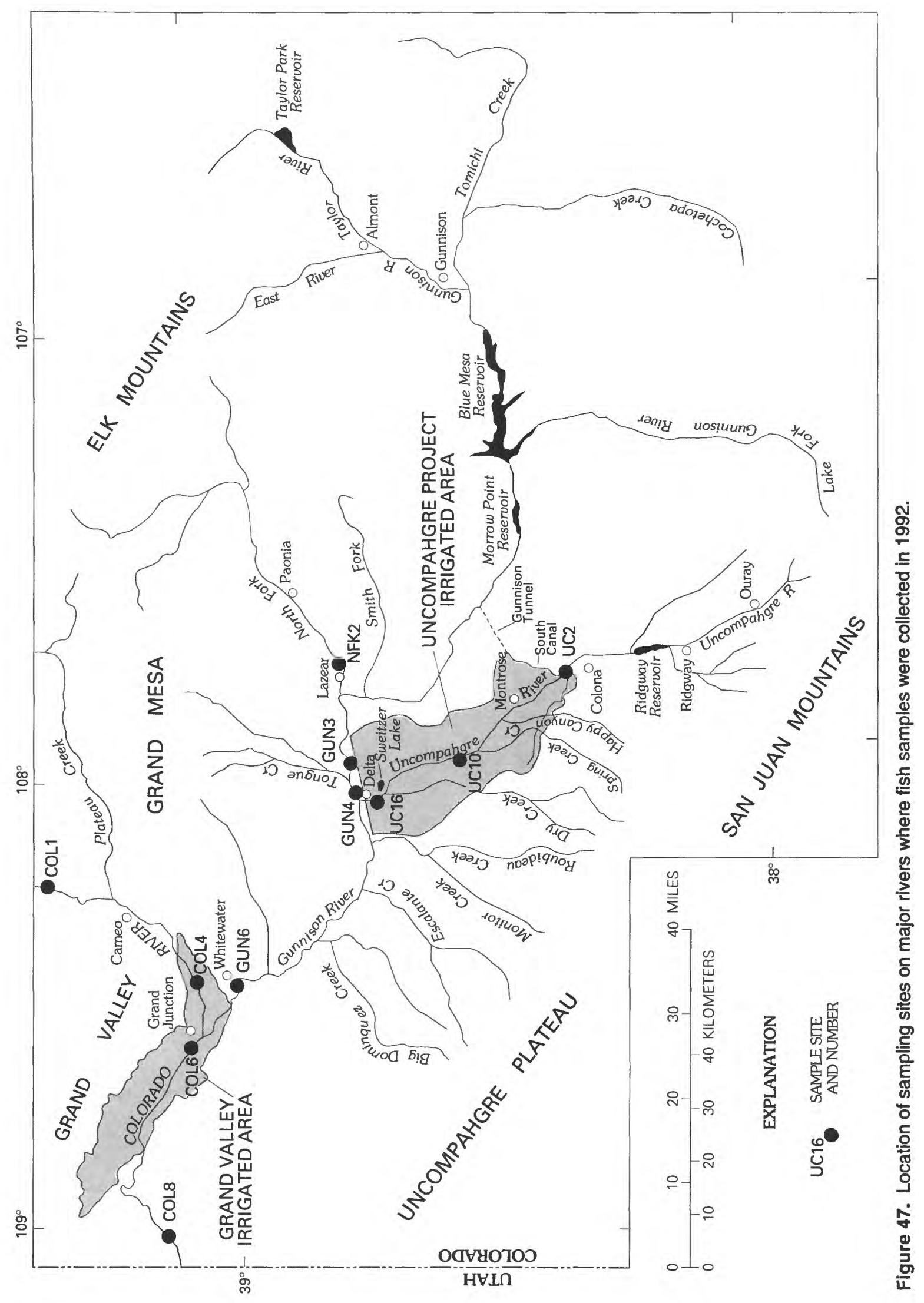




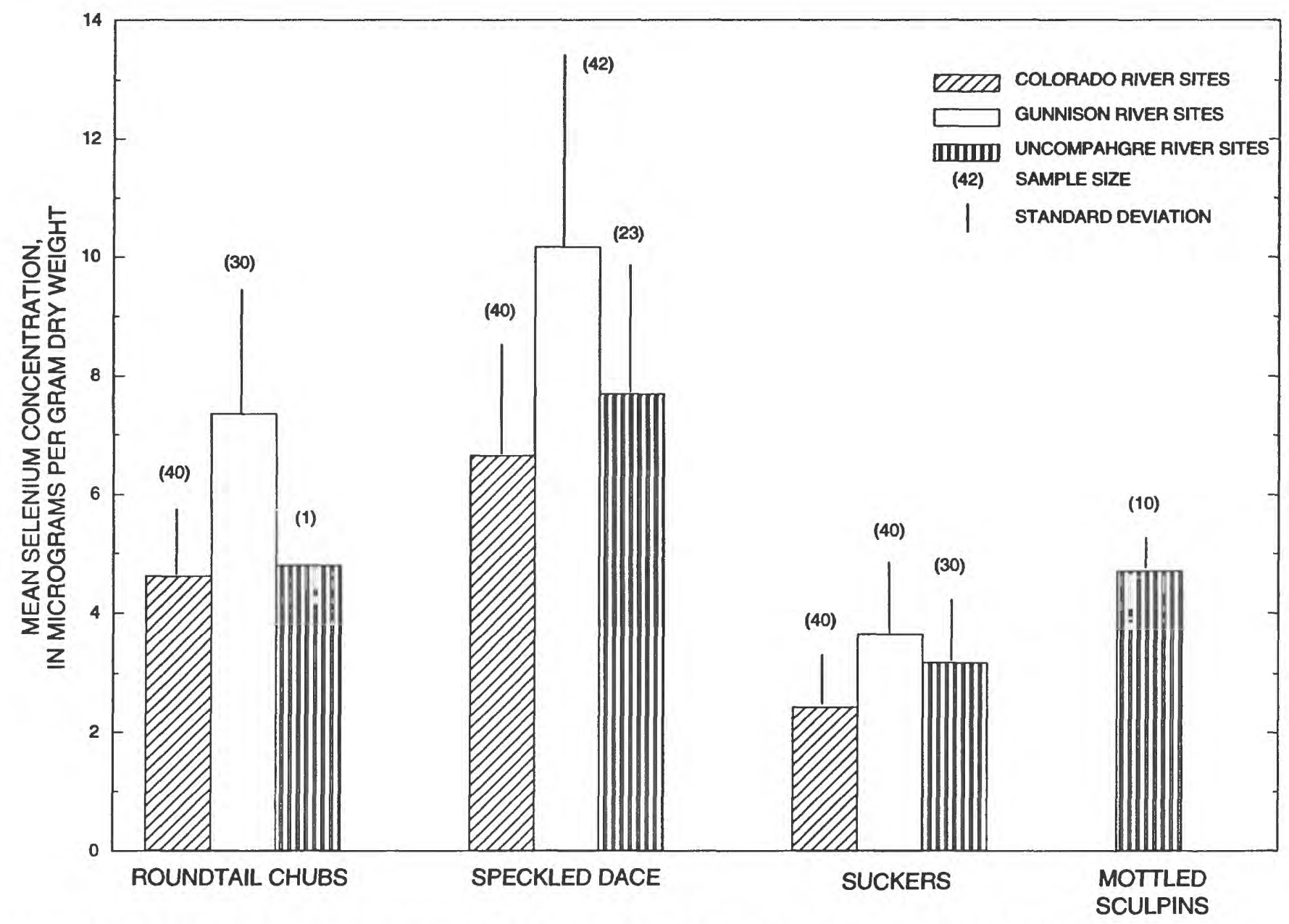

Figure 48. Mean selenium concentrations in four fish-trophic groups in the Colorado, North Fork of the Gunnison, Gunnison, and Uncompahgre Rivers.

Mean selenium concentrations in fish representing three fish-trophic groups collected from four sites in the Gunnison River Basin are shown in figure 50. The mean selenium concentrations for suckers collected from the two lower Gunnison River Basin sites (sites GUN4 and GUN6 in fig. 47) were significantly higher ( $p$-value less than 0.05 ) than mean selenium concentrations for suckers collected from the two upper sites (sites NFK2 and GUN3). Speckled dace collected from the outflow site for the Gunnison River Basin (site GUN6) contained a significantly higher mean selenium concentration than speckled dace from the other three sites (fig. 50). There was no significant difference among selenium concentrations in roundtail chubs for the Gunnison River Basin sites.
Mean selenium concentrations in three fishtrophic groups collected from three Uncompahgre River sites are shown in figure 51. There was not a significant difference in mean selenium concentrations among the three sites for speckled dace, although the upper site (site UC2 in fig. 47) contained the highest mean selenium concentration. The mean selenium concentration for suckers collected at the outflow site for the Uncompahgre River (site UC16) was significantly higher than the concentrations from the upper two sites (p-value less than 0.05) (fig. 51). Because only one roundtail chub sample was collected from the Uncompahgre River, comparisons among sites were not possible. 
Table 29. Number of whole-body fish samples collected in 1992 from the Colorado, North Fork of the Gunnison, Gunnison, and Uncompahgre Rivers that exceeded the 1984 National Contaminant Biomonitoring Program (NCBP) 85th-percentile concentrations for seven trace constituents

[NCBP 85th-percentile concentrations in micrograms per gram wet weight; NCBP data from Schmitt and Brumbaugh (1990); N, number of samples; numbers in brackets are the number of exceedances expressed as a percentage of the number of samples in each group]

\begin{tabular}{|c|c|c|c|c|}
\hline $\begin{array}{c}\text { Trace } \\
\text { constituent }\end{array}$ & $\begin{array}{c}\text { NCBP } \\
\text { 85th } \\
\text { percentile }\end{array}$ & $\begin{array}{c}\text { Colorado } \\
\text { Rlver } \\
(\mathrm{N}=120)\end{array}$ & $\begin{array}{l}\text { North Fork } \\
\text { of the } \\
\text { Gunnlson } \\
\text { and } \\
\text { Gunnlson } \\
\text { Rlvers } \\
(\mathrm{N}=112)\end{array}$ & $\begin{array}{l}\text { Uncompahgre } \\
\text { Rlver } \\
(N=64)\end{array}$ \\
\hline Arsenic & 0.27 & $8[6]$ & $9[8]$ & $6[9]$ \\
\hline Cadmium $^{1}$ & .05 & $4[3]$ & 3 [3] & $18[28]$ \\
\hline Copper & 1.0 & 18 [15] & $42[38]$ & 15 [23] \\
\hline Lead $^{1}$ & .22 & 23 [19] & 15 [13] & 17 [27] \\
\hline Mercury & .17 & $19[16]$ & 13 [12] & $0[0]$ \\
\hline Selenium & .73 & 95 [79] & $108[96]$ & $51[80]$ \\
\hline Zinc & 34.2 & $36[30]$ & $28[25]$ & $13[20]$ \\
\hline
\end{tabular}

${ }^{1}$ Some samples had reporting limits equal to or greater than the 1984 NCBP 85th percentile.

A paired t-test was used to test for differences between mean selenium concentrations in liver and whole-body samples from suckers. As expected from other researchers' findings (Sager and Cofield, 1984), liver samples contained significantly higher selenium concentrations than wholebody samples. However, selenium concentrations in all fish-liver samples were less than the concentration of concern of $12 \mu \mathrm{g} / \mathrm{g}$ dry weight (Lemly, 1993).

\section{Risk Assessment for Endangered Fish from Selenate and Selenite}

Acute toxicity tests of the selenium species

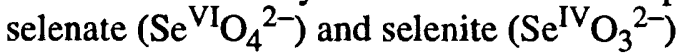
on hatchery-raised Colorado squawfish and razorback suckers were conducted during 1993 (S.J. Hamilton, National Biological Service, written commun., 1993). The two endangered fish species are endemic to the Colorado River in and downstream from the Grand Valley. Selenate and selenite analyses were done only on five water samples from the Grand Valley; therefore, risk assessment was not done for the
Uncompahgre Project area. Three different life stages of each of the two fish species were exposed to the inorganic constituents of interest. Concentrations representing 96-hour LC50 values (lethal concentration for 50 percent of the test organism during a 96-hour test) were calculated (table 30). The toxicity data in table 30 indicate that selenite selenium is toxic to Colorado squawfish and razorback suckers at lower concentrations than selenate selenium.

One method used to estimate the hazard of chemicals to aquatic life is the margin of safety (or margin of uncertainty) between expected environmental concentrations (EEC) of a chemical and concentrations of the chemical that cause toxic effects in organisms. The 96-hour LC50 concentrations for the two endangered fish species were used to determine the biologically effective concentration (BEC). The BEC values were compared to environmental concentrations of selenate and selenite in water samples (the EEC values) collected from five drainages in the Grand Valley, which are the $\mathrm{BEC} / \mathrm{EEC}$ ratios. The hazard ratios used to assess potential risk are based on dissolved selenium in the water. Although most selenium is bioaccumulated through the food chain into upper trophic levels of aquatic ecosystems (Lemly and Smith, 1987; Ohlendorf, 1989; Maier and Knight, 1994), waterborne selenium is an important indicator of bioaccumulation potential. Based on lethal effects observed in acute toxicity tests, hazard ratios (BEC/EEC) of less than 100 indicate a high potential for hazardous environmental conditions and the potential for toxicity (Cairns and others, 1978).

Hazard assessments for three life stages [0- to 98-day old (swim-up), 99- to 115-day old, and 193- to 207-day old] of Colorado squawfish and razorback suckers are summarized in table 31 . The selenate concentrations in the five Grand Valley drainages could theoretically pose a moderate risk (BEC/EEC ratios between 100 and 1,000 ) to the swim-up life stage of the Colorado squawfish and to all tested life stages of the razorback sucker (table 31). For all three life stages of both species, selenite concentrations were in the low risk category or in the range of uncertainty (BEC/EEC ratios between 1,000 and 5,000 ). Adult Colorado squawfish and razorback suckers use backwater habitats in the Colorado River during spring prior to spawning. 


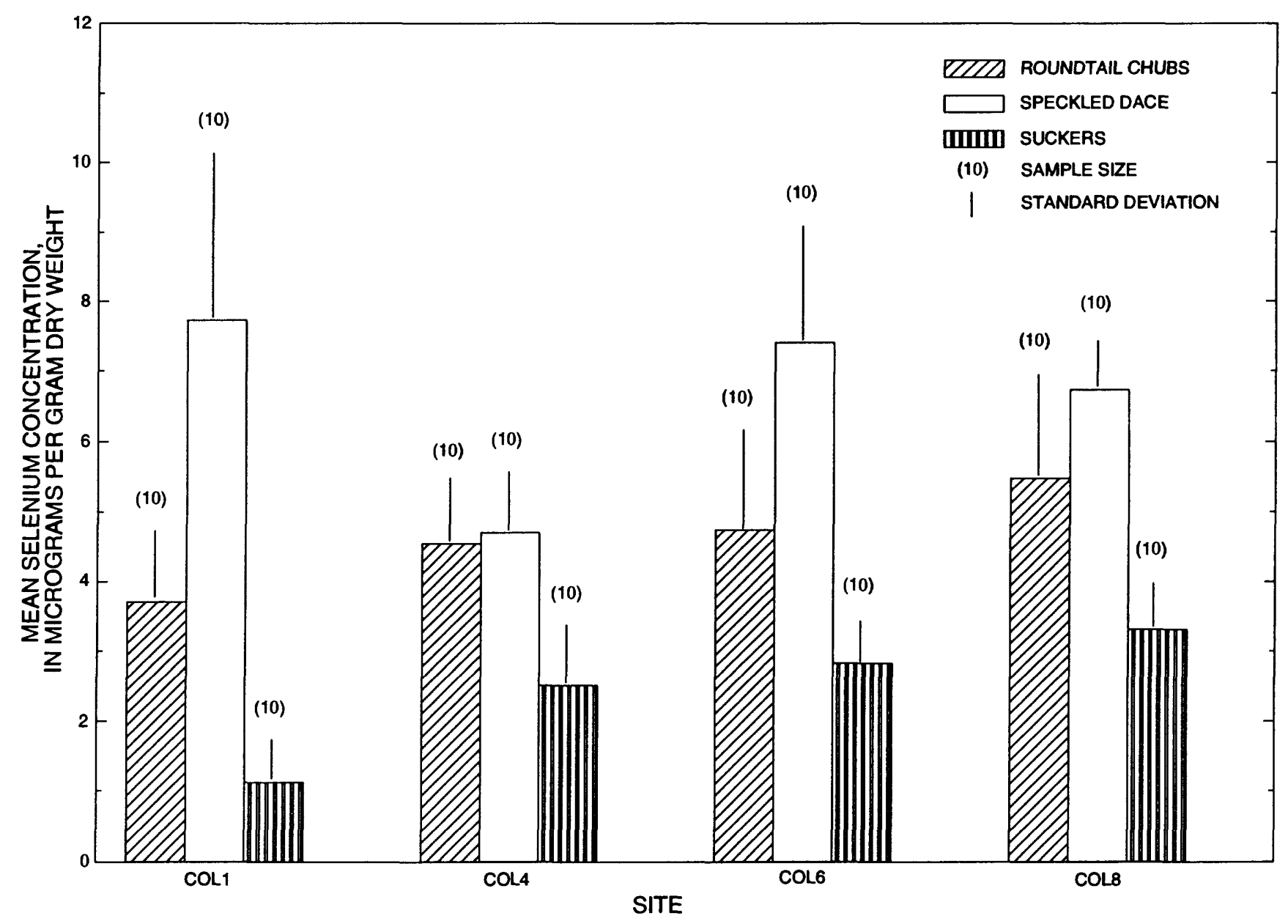

Figure 49. Mean selenium concentrations in three fish-trophic groups collected from four sites on the Colorado River. Sites are in downstream order from left to right.

\section{Other Trace-Constituent Concentrations in Fish Tissues and Fish Food Items in Irrigated Areas}

\section{Uncompahgre Project Area}

Other trace constituents in whole-body fish samples that exceeded the 1984 NCBP 85 th-percentile concentrations are listed in table 26. Other than selenium, copper most often exceeded the 1984 NCBP 85th-percentile concentration for whole-body fish. Moore and Ramamoorthy (1984) suggested that, in unpolluted freshwater, maximum copper concentrations in fish muscle tissue seldom exceed $1 \mu \mathrm{g} / \mathrm{g}$ wet weight ( $4 \mu \mathrm{g} / \mathrm{g}$ dry weight at 75 -percent moisture). All copper concentrations in fillet samples collected from the Uncompahgre Project area were less than this guideline concentration. Dixon and Sprague (1981) reported that rainbow trout exposed to $30 \mu \mathrm{g} / \mathrm{L}$ copper for 7 to 21 days accumulated whole-body concentrations of 10 to $11 \mu \mathrm{g} / \mathrm{g}$ dry weight copper. This concentration range is similar to copper concentrations in some whole-body trout samples collected in the Uncompahgre Project area (sites HCC1, SP4, DRY1, and CR in figs. 44 and 45) (Butler and others, 1994). Dixon and Sprague (1981) reported that mean copper residues in trout prior to copper exposure ranged from 3.2 to $4.5 \mu \mathrm{g} / \mathrm{g}$ dry weight, which also are similar to copper concentrations in some whole-body trout samples collected in the Uncompahgre Project area. Dixon and Sprague (1981) reported that rainbow trout were able to acclimate to copper, which significantly altered their lethal tolerance. Moore and Ramamoorthy (1984) indicated that copper concentrations of 10 to $100 \mu \mathrm{g} / \mathrm{g}$ dry weight in aquatic plants and 5 to 


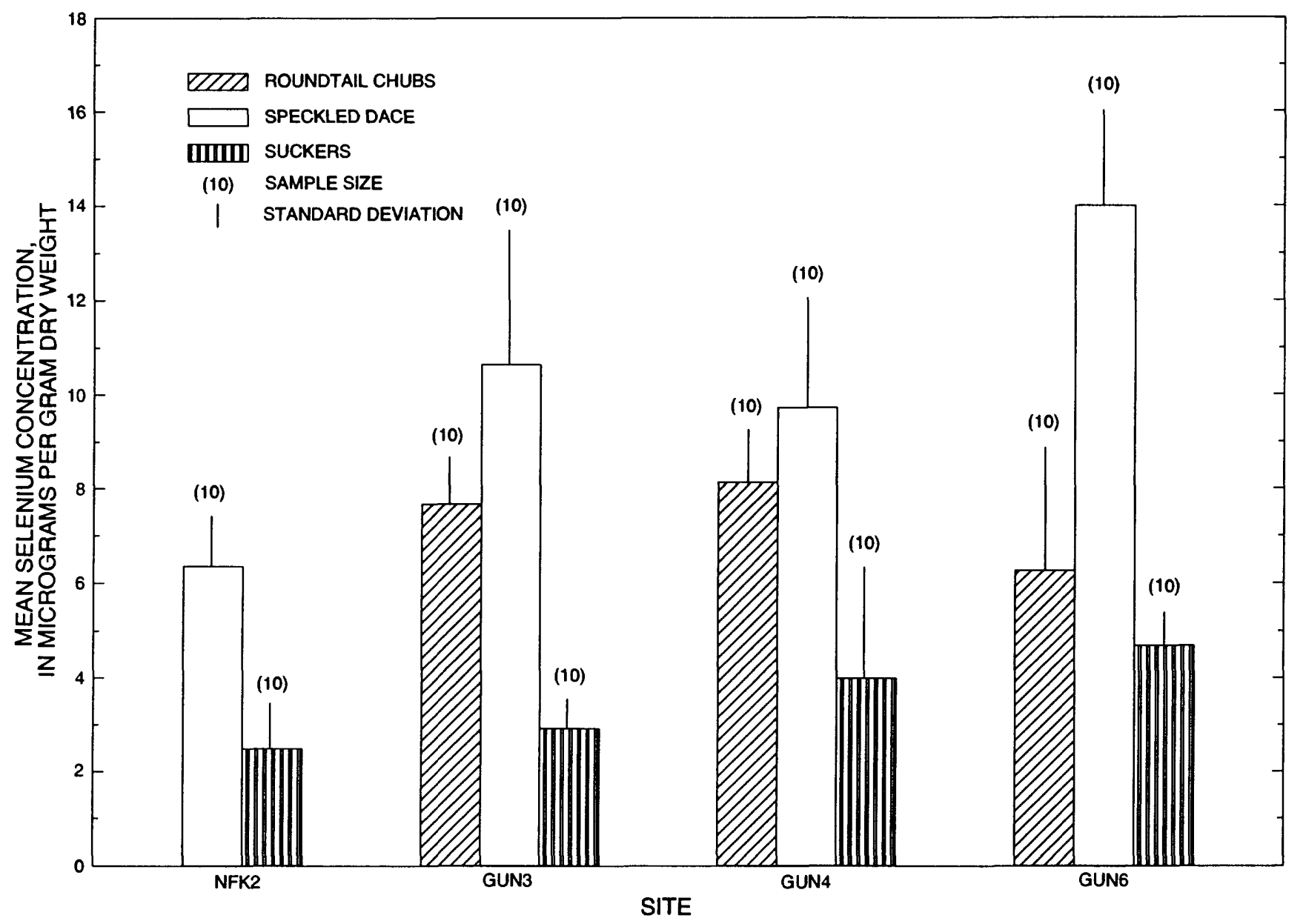

Figure 50. Mean selenium concentrations in three fish-trophic groups collected from four sites in the Gunnison River Basin. Sites are in downstream order from left to right.

$200 \mu \mathrm{g} / \mathrm{g}$ dry weight in aquatic invertebrates were indicative of copper-polluted freshwater systems. Aquatic-plant and -invertebrate samples collected from the Uncompahgre Project area contained copper concentrations in these ranges.

About 20 percent of the cadmium concentrations in whole-body fish collected within and adjacent to the Uncompahgre Project exceeded the NCBP 85th percentile (table 26). Cadmium concentrations were less than the $2-\mu \mathrm{g} / \mathrm{g}$ wet-weight concentration that Moore and Ramamoorthy (1984) indicated was evidence of probable contamination and less than the $5-\mu \mathrm{g} / \mathrm{g}$ wet-weight concentration that Eisler (1985) reported was a possible toxic cadmium concentration for fish.

Concentrations of arsenic, lead, and mercury in a few whole-body fish samples exceeded 1984 NCBP 85th percentiles (table 26). Moore and Ramamoorthy
(1984) indicated that, in unpolluted or mildly contaminated water, arsenic concentrations in whole-body fish should not exceed the range of less than 0.1 to $0.4 \mu \mathrm{g} / \mathrm{g}$ wet weight. Fish samples from Dry Creek (site DRY1 in fig. 44) $(0.55 \mu \mathrm{g} / \mathrm{g}$ wet weight), Roubideau Creek (site RB1) $(0.63 \mu \mathrm{g} / \mathrm{g}$ wet weight), and Crawford Reservoir (site CR in fig. 45) $(2.54 \mu \mathrm{g} / \mathrm{g}$ wet weight) exceeded this guideline. Diminished growth and survival have been reported for bluegills when arsenic residues in muscle tissue exceeded $11.3 \mu \mathrm{g} / \mathrm{g}$ wet weight in immature fish or $5 \mu \mathrm{g} / \mathrm{g}$ wet weight in the adults (Natural Resources Council of Canada, 1978). A whole-body yellow perch sample collected from Crawford Reservoir (site CR) had an arsenic concentration $(2.54 \mu \mathrm{g} / \mathrm{g}$ wet weight) that was comparable to the toxic arsenic concentrations in adult bluegill muscle. Lead concentrations in whole-body fish exceeded the 1984 NCBP 


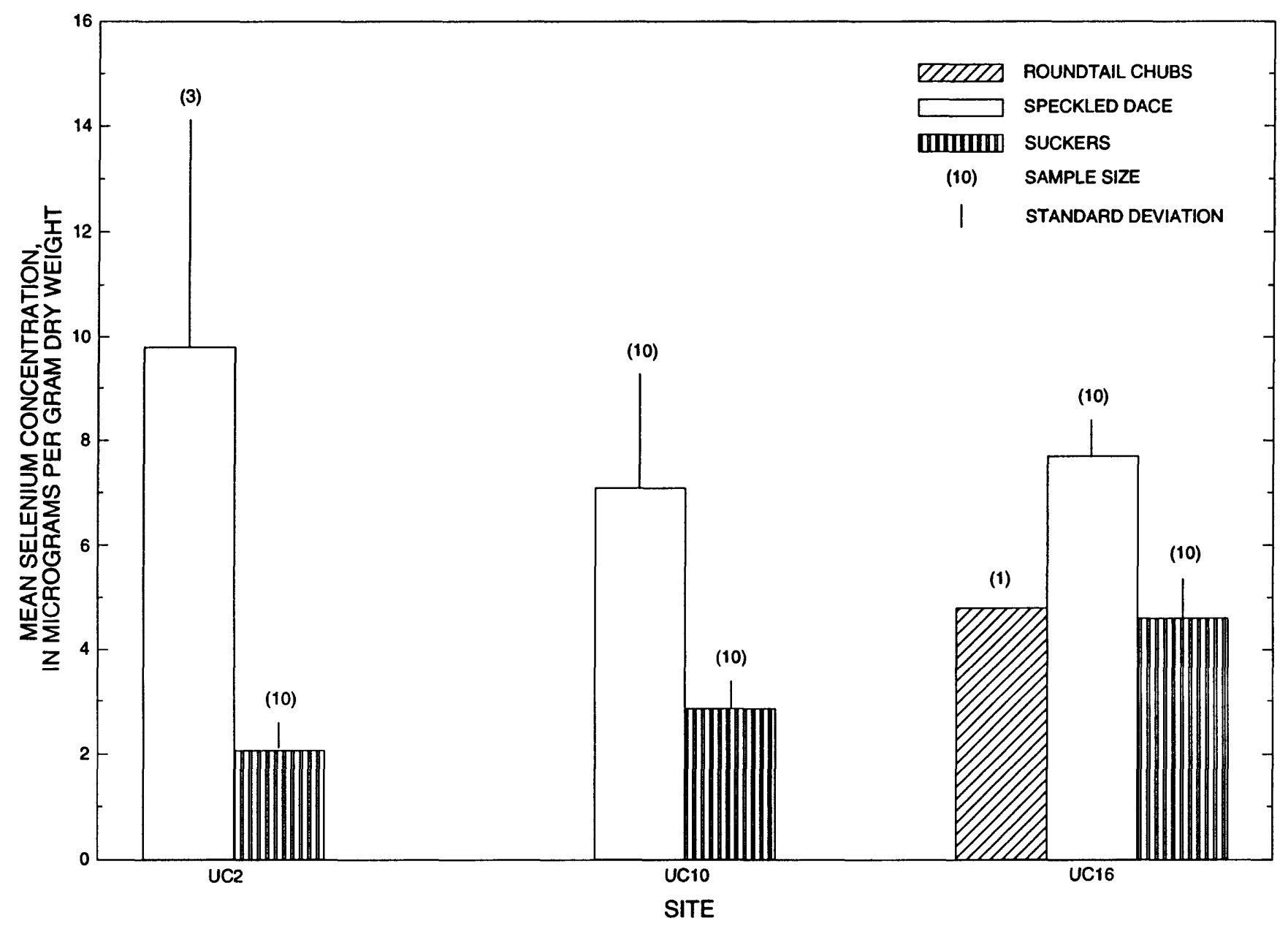

Figure 51. Mean selenium concentrations in three fish-trophic groups collected from three sites on the Uncompahgre River. Sites are in downstream order from left to right.

85th percentile for two samples collected east of the Uncompahgre River and nine samples collected west of the Uncompahgre River (table 26). Highest lead concentrations were in two bluehead sucker samples collected from Dry Creek and Roubideau Creek (sites DRY1 and RB1 in fig. 44). Four wholebody fish samples collected from tributaries west of the Uncompahgre River contained mercury concentrations that exceeded the 1984 NCBP 85 th percentile of $0.1 \mu \mathrm{g} / \mathrm{g}$ wet weight (table 26) and exceeded the dietary guideline of $0.1 \mu \mathrm{g} / \mathrm{g}$ wet weight for the protection of sensitive consumer bird species (Eisler, 1987a). The highest mercury concentration of $0.34 \mu \mathrm{g} / \mathrm{g}$ wet weight was in a speckled dace sample from Spring Creek (site SP4 in fig. 44).
Table 30. Concentrations of selenate and selenite selenium causing acute toxicity to Colorado squawfish and razorback suckers

[96-hour LC50 concentration is the lethal concentration for 50 percent of the test organisms during a 96-hour exposure; data from Hamilton (1993)]

\begin{tabular}{ccccc}
\hline \multirow{2}{*}{$\begin{array}{c}\text { Llfe } \\
\text { stage } \\
\text { (age, } \\
\text { in days) }\end{array}$} & \multicolumn{2}{c}{$\begin{array}{c}\text { 96-hour LC50 concentrations, } \\
\text { in micrograms per liter }\end{array}$} \\
\cline { 2 - 3 } & \multicolumn{2}{c}{$\begin{array}{c}\text { Colorado } \\
\text { squawfish }\end{array}$} & \multicolumn{2}{c}{$\begin{array}{c}\text { Razorback } \\
\text { sucker }\end{array}$} \\
\cline { 2 - 5 } \cline { 5 - 5 } & Selenate & Selenite & Selenate & Selenite \\
\hline $\begin{array}{c}\text { Less than } 99 \\
\text { (swim-up) }\end{array}$ & 67,000 & 14,000 & 48,000 & 15,000 \\
99 to 115 & 297,000 & 36,000 & 35,000 & 9,200 \\
193 to 207 & 320,000 & 31,000 & 26,000 & 16,000 \\
\hline
\end{tabular}


Table 31. Hazard assessment of selenate and selenite selenium in water samples collected in March 1992 from five streams in the Grand Valley to three life stages of Colorado squawfish and razorback suckers

[Selenate and selenite data from R.F. Fujii (U.S. Geological Survey, written commun., 1992); $\mu \mathrm{g} /$, micrograms per liter; hazard assessment is equal to $\mathrm{BEC} / \mathrm{EEC}$, where $\mathrm{BEC}$ is the biologically effective concentration and EEC is the estimated environmental concentration of a contaminant; a hazard assessment greater than 5,000 is low risk, 1,000 to 5,000 is uncertain risk, 100 to 1,000 is moderate risk, and less than 100 is high risk (Cairns and others, 1978); -- , no risk assessment because contaminant concentration was 0 microgram per liter]

\begin{tabular}{|c|c|c|c|c|c|c|c|c|}
\hline \multirow[b]{3}{*}{ Stream } & \multicolumn{4}{|c|}{ Selenate selenlum } & \multicolumn{4}{|c|}{ Selenite selenium } \\
\hline & \multirow[b]{2}{*}{$\begin{array}{c}\text { Water } \\
\text { concentration } \\
(\mu g /)\end{array}$} & \multicolumn{3}{|c|}{ BEC/EEC for the three life stages } & \multirow[b]{2}{*}{$\begin{array}{c}\text { Water } \\
\text { concentration } \\
(\mu g / L)\end{array}$} & \multicolumn{3}{|c|}{ BEC/EEC for the three life stages } \\
\hline & & $\begin{array}{l}\text { Less than } \\
99 \text { days old } \\
\text { (swim-up) }\end{array}$ & $\begin{array}{c}99 \text { to } \\
115 \text { days old }\end{array}$ & $\begin{array}{l}193 \text { to } \\
207 \text { days old }\end{array}$ & & $\begin{array}{l}\text { Less than } \\
99 \text { days old } \\
\text { (swim-up) }\end{array}$ & $\begin{array}{l}99 \text { to } \\
115 \text { days old }\end{array}$ & $\begin{array}{c}193 \text { to } \\
207 \text { days old }\end{array}$ \\
\hline \multicolumn{9}{|c|}{ COLORADO SQUAWFISH } \\
\hline Salt Creek & 71.7 & 934 & 4,142 & 4,463 & 1.1 & 12,727 & 32,727 & 28,182 \\
\hline Reed Wash & 126.2 & 531 & 2,353 & 2,536 & 0 & -- & - & -- \\
\hline Adobe Creek & 72.5 & 924 & 4,097 & 4,414 & 2.3 & 6,087 & 15,652 & 13,478 \\
\hline Leach Creek & 83.4 & 803 & 3,561 & 3,837 & 2.2 & 6,364 & 16,364 & 14,091 \\
\hline Indian Wash & 82.8 & 809 & 3,587 & 3,865 & 3.3 & 4,242 & 10,909 & 9,394 \\
\hline \multicolumn{9}{|c|}{ RAZORBACK SUCKER } \\
\hline Salt Creek & 71.7 & 670 & 488 & 363 & 1.1 & 13,636 & 8,364 & 14,546 \\
\hline Reed Wash & 126.2 & 380 & 277 & 206 & 0 & -- & -- & -- \\
\hline Adobe Creek & 72.5 & 662 & 483 & 359 & 2.3 & 6,522 & 4,000 & 6,957 \\
\hline Leach Creek & 83.4 & 576 & 420 & 312 & 2.2 & 6,818 & 4,182 & 7,273 \\
\hline Indian Wash & 82.8 & 580 & 423 & 314 & 3.3 & 4,546 & 2,788 & 4,849 \\
\hline
\end{tabular}

About 22 percent of the zinc concentrations in whole-body fish samples collected in the Uncompahgre Project area exceeded the 1984 NCBP 85th-percentile concentration (table 26). Schmitt and Brumbaugh (1990) reported that the mean zinc concentration in common carp $(63.4 \mu \mathrm{g} / \mathrm{g}$ wet weight) was significantly higher than the mean for all other species combined. The highest zinc concentrations in fish collected from the Uncompahgre Project area were in carp from sites NFK2, CMG1, and RB1 (figs. 44 and 45), and these concentrations (Butler and others, 1994, tables 25 and 27) were comparable to the geometric mean concentrations in carp reported by Schmitt and Brumbaugh (1990).

Some samples collected from tributaries west of the Uncompahgre River had concentrations that exceeded NCBP 85th percentiles for each of the seven trace constituents. In other streams in the Uncompahgre River Basin, these exceedances could be attributed to pollution from mining activities. However, no mining is occurring on the Uncompahgre Plateau upstream from the irrigated areas, which is the source of the natural runoff in tributary streams on the western side of the project. The trace constituents probably were introduced in the irrigation water diverted from the Uncompahgre River, which may be affected by runoff from previous mining activities.

\section{Grand Valley}

As in the Uncompahgre Project area, copper was the trace constituent other than selenium that most often exceeded the 1984 NCBP 85th-percentile concentration for whole-body fish from the Grand Valley (table 28). Highest copper concentrations were $3.0 \mu \mathrm{g} / \mathrm{g}$ wet weight $(11.1 \mu \mathrm{g} / \mathrm{g}$ dry weight) in a red shiner sample collected from Lewis Wash (site LW in fig. 46) and $3.0 \mu \mathrm{g} / \mathrm{g}$ wet weight $(10.2 \mu \mathrm{g} / \mathrm{g}$ dry weight) in the speckled dace sample from Salt Creek (site SC) (Butler and others, 1994, tables 28 and 30). These concentrations are within the range of copper concentrations in rainbow trout after exposure to $30 \mu \mathrm{g} / \mathrm{L}$ copper for 7 to 21 days (Dixon and Sprague, 1981). Most copper concentrations in whole-body fish collected from the Grand Valley were 
comparable to the pre-exposure concentrations of 3.2 to $4.5 \mu \mathrm{g} / \mathrm{g}$ dry weight reported by Dixon and Sprague (1981).

Only two arsenic concentrations in wholebody fish from streams exceeded the 1984 NCBP 85 th-percentile concentration; $0.32 \mu \mathrm{g} / \mathrm{g}$ wet weight in a bluehead sucker from Leach Creek (site LC1 in fig. 46) and $0.32 \mu \mathrm{g} / \mathrm{g}$ wet weight in a bluehead sucker sample from Salt Creek (site SC) (Butler and others, 1994, tables 29 and 30). All cadmium concentrations were less than the $2-\mu \mathrm{g} / \mathrm{g}$ wet-weight concentration in whole-body vertebrates that Moore and Ramamoorthy (1984) suggested was evidence of probable cadmium contamination.

Fourteen whole-body fish samples collected from Grand Valley tributaries and two samples collected from Highline Reservoir (site HR in fig. 46) contained lead concentrations that exceeded the 1984 NCBP 85th-percentile concentration (table 28). All mercury concentrations in Grand Valley fish were less than the 1984 NCBP 85th-percentile concentration (table 28).

Zinc concentrations in fish from the Grand Valley were comparable to the concentrations in fish collected in the Uncompahgre Project area. Highest zinc concentrations in Grand Valley fish (Butler and others, 1994, tables 28-30) were in a red shiner sample collected from Lewis Wash (site LW in fig. 46) in the east Grand Valley and in a speckled dace sample collected from Salt Creek (site SC) in the west Grand Valley.

\section{Other Trace-Constituent Concentrations in Fish Tissues and Fish Food Items from Mainstem Rivers}

In addition to selenium, copper and zinc had the greatest number of exceedances of the 1984 NCBP 85th-percentile concentrations (Schmitt and Brumbaugh, 1990) for whole-body fish collected from the three major river basins (table 29). Samples from North Fork of the Gunnison and the Gunnison River had a higher proportion of copper exceedances (38 percent) than samples from the Uncompahgre River (23 percent) and the Colorado River (15 percent). All of the fish samples from the Uncompahgre and Colorado Rivers that exceeded the 1984 NCBP 85 th percentile for copper contained between 1 and $2.5 \mu \mathrm{g} / \mathrm{g}$ wet weight (Butler and others, 1994, tables 36 and 37). However, 13 of the Gunnison River fish samples had copper concentrations that exceeded $2.5 \mu \mathrm{g} / \mathrm{g}$ wet weight and ranged from 2.68 to $86.2 \mu \mathrm{g} / \mathrm{g}$ wet weight. The copper concentrations in Gunnison River fish samples indicated considerable exposure to a copper-contaminated environment (Dixon and Sprague, 1981; Moore and Ramamoorthy, 1984).

Exceedances of the 1984 NCBP 85th percentile for arsenic were fairly evenly distributed among the three major river basins (table 29). According to Moore and Ramamoorthy (1984), arsenic concentrations of less than 0.1 to $0.4 \mu \mathrm{g} / \mathrm{g}$ wet weight were indicative of fish from environments uncontaminated by arsenic. Eight samples from the Gunnison River and two samples from the Uncompahgre River exceeded the guideline concentration of $0.4 \mu \mathrm{g} / \mathrm{g}$ wet weight. Fish samples collected from the Uncompahgre River contained the highest proportion of concentrations that exceeded the NCBP 85th percentiles for cadmium and lead (table 29). All cadmium concentrations were less than the guideline concentration of $2 \mu \mathrm{g} / \mathrm{g}$ wet weight that Moore and Ramamoorthy (1984) indicated was evidence of probable cadmium contamination. The highest lead concentrations were in two flannelmouth sucker samples collected from the Gunnison River in Delta (site GUN4 in fig. 47), at 4.0 and $6.6 \mu \mathrm{g} / \mathrm{g}$ dry weight (Butler and others, 1994, table 35). Several samples had reporting limits for lead greater than the 1984 NCBP 85 th percentile; therefore, the actual number of exceedances is not known.

Mercury concentrations in about 16 percent of Colorado River fish samples and about 12 percent of Gunnison River fish samples exceeded the 1984 NCBP 85th-percentile concentration (table 29). None of the Uncompahgre River fish samples contained mercury concentrations that exceeded the 1984 NCBP 85th percentile. All mercury concentrations in fish from the Colorado and Gunnison Rivers that exceeded the 1984 NCBP 85 th percentile also exceeded the $0.1-\mu \mathrm{g} / \mathrm{g}$ wet-weight concentration that is recommended for the protection of sensitive consumer bird species (Eisler, 1987a), but were less than the whole-body concentration of $5 \mu \mathrm{g} / \mathrm{g}$ wet weight for the protection of brook trout (Armstrong, 1979). 
Fish from the Colorado River had the highest proportion of concentrations that exceeded the NCBP 85 th percentile for zinc ( 30 percent), followed by the Gunnison River (25 percent) and the Uncompahgre River (20 percent) (table 29). Schmitt and Brumbaugh (1990) reported high variability in zinc concentrations among fish species. Of all fish collected from mainstem rivers during this study, speckled dace often had the greatest proportion of zinc concentrations that exceeded the NCBP 85 th percentile.

\section{Risk Assessment for Endangered Fish from Four Trace Constituents}

Acute toxicity tests for boron, uranium, vanadium, and zinc were conducted (Hamilton, 1993) on three different life stages of Colorado squawfish and razorback suckers by methods similar to that described for selenium. Lethal concentrations (LC50's) for each of the three life stages of Colorado squawfish and razorback suckers are listed in table 32. As was done for selenium, the 96-hour LC50 concentrations for the two endangered fish species (BEC) were compared to actual concentrations of boron, uranium, vanadium, and zinc in water samples (EEC) collected from five Grand Valley drainages. Hazard assessments (the BEC/EEC ratios) for each life stage of the two endangered fish species were calculated for the four trace constituents. Maximum water concentrations of the four trace constituents (Butler and others, 1994, table 5) were used to determine the BEC/EEC ratio so that the maximum hazard could be estimated. Hazard assessments for the three life stages of each endangered fish species are listed in table $\mathbf{3 3}$ for boron and uranium and in table 34 for vanadium and zinc.

Most of the hazard estimates for boron, vanadium, and zinc (tables 33 and 34) are in the moderate range of risk; the $\mathrm{BEC} / \mathrm{EEC}$ ratio usually was between 100 and 1,000. Of most concern are zinc concentrations in Adobe Creek, Leach Creek, and Indian Wash, which were in the high-risk category for the swim-up life stage of Colorado squawfish. Most of the hazard ratios for uranium (table 33) were greater than 1,000 , but less than 5,000 , which is in the range of uncertain risk.
Table 32. Concentrations of boron, uranium, vanadium, and zinc causing acute toxicity to Colorado squawfish and razorback suckers

[96-hour LC50 concentration is the lethal concentration for 50 percent of the test organisms during a 96-hour exposure; >, greater than; data from Hamilton (1993)]

\begin{tabular}{|c|c|c|c|c|}
\hline \multirow{2}{*}{$\begin{array}{l}\text { Life stage } \\
\text { (age, in days) }\end{array}$} & \multicolumn{4}{|c|}{$\begin{array}{l}\text { 96-hour LC50 concentration, } \\
\text { in micrograms per liter }\end{array}$} \\
\hline & Boron & Uranium & Vanadium & Zinc \\
\hline \multicolumn{5}{|c|}{ COLORADO SQUAWFISH } \\
\hline $\begin{array}{r}\text { Less than } 99 \\
\text { (swim-up) }\end{array}$ & 279,000 & 46,000 & 7,800 & 1,700 \\
\hline 99 to 115 & $>100,000$ & 46,000 & 3,800 & 4,200 \\
\hline 193 to 207 & 511,000 & 46,000 & 4,200 & 12,000 \\
\hline \multicolumn{5}{|c|}{ RAZORBACK SUCKERS } \\
\hline $\begin{array}{r}\text { Less than } 99 \\
\text { (swim-up) }\end{array}$ & 254,000 & 46,000 & 8,700 & 4,000 \\
\hline 99 to 115 & 279,000 & 46,000 & 4,000 & 6,400 \\
\hline 193 to 207 & $>100,000$ & 46,000 & 3,200 & 15,000 \\
\hline
\end{tabular}

\section{Organic Contaminants in Fish Tissues}

Four fish samples collected in the Uncompahgre Project area and two fish samples collected in the Grand Valley area were analyzed for organochlorine pesticides and polychlorinated biphenyls (PCB's) (Butler and others, 1994, table 38). One flannelmouth sucker sample collected from Dry Creek (site DRY1 in fig. 44) contained concentrations of p,p'-DDE $(0.63 \mu \mathrm{g} / \mathrm{g}$ wet weight), p,p'-DDD $(0.08 \mu \mathrm{g} / \mathrm{g}$ wet weight), p,p'-DDT $(0.14 \mu \mathrm{g} / \mathrm{g}$ wet weight), dieldrin $(0.09 \mu \mathrm{g} / \mathrm{g}$ wet weight), and toxaphene $(0.82 \mu \mathrm{g} / \mathrm{g}$ wet weight) that exceeded the 1984 NCBP geometric mean concentrations for these compounds (table 35) (Schmitt and others, 1990). A white sucker sample collected from Roubideau Creek (fig. 44) also contained a p,p'-DDE concentration $(0.41 \mu \mathrm{g} / \mathrm{g}$ wet weight) that was higher than the 1984 NCBP geometric mean concentration. The organic compound p,p'-DDE is the most persistent degradation product of the parent compound p,p'-DDT. DDT was banned in the United States in 1972. Schmitt and others (1990) reported that the percentage of total DDT that consists of DDE has increased steadily from 48 percent in 1970 to 73 percent in 1984. 
Table 33. Hazard assessment of boron and uranium in water samples collected from five streams in the Grand Valley to three life stages of Colorado squawfish and razorback suckers

[ $\mu \mathrm{g} / \mathrm{L}$, micrograms per liter; hazard assessment is equal to BEC/EEC, where BEC is the biologically effective concentration and EEC is the estimated environmental concentration of a contaminant; a hazard assessment greater than 5,000 is low risk, 1,000 to 5,000 is uncertain risk, 100 to 1,000 is moderate risk, and less than 100 is high risk; >, greater than]

\begin{tabular}{|c|c|c|c|c|c|c|c|c|}
\hline \multirow[b]{3}{*}{ Stream } & \multicolumn{4}{|c|}{ Boron } & \multicolumn{4}{|c|}{ Uranium } \\
\hline & \multirow{2}{*}{$\begin{array}{c}\text { Maximum } \\
\text { water } \\
\text { concentration } \\
(\mu g / L)\end{array}$} & \multicolumn{3}{|c|}{ BEC/EEC for the three life stages } & \multirow{2}{*}{$\begin{array}{c}\text { Maximum } \\
\text { water } \\
\text { concentration } \\
(\mu g / L)\end{array}$} & \multicolumn{3}{|c|}{ BEC/EEC for the throe life stages } \\
\hline & & $\begin{array}{l}\text { Less than } \\
99 \text { days old } \\
\text { (swim-up) }\end{array}$ & $\begin{array}{c}99 \text { to } \\
115 \text { days old }\end{array}$ & $\begin{array}{c}193 \text { to } \\
207 \text { days old }\end{array}$ & & $\begin{array}{l}\text { Less than } \\
99 \text { days old } \\
\text { (swim-up) }\end{array}$ & $\begin{array}{c}99 \text { to } \\
115 \text { days old }\end{array}$ & $\begin{array}{c}193 \text { to } \\
207 \text { days old }\end{array}$ \\
\hline \multicolumn{9}{|c|}{ COLORADO SQUAWFISH } \\
\hline Salt Creek & 330 & 846 & $>303$ & 1,549 & 23 & 2,000 & 2,000 & 2,000 \\
\hline Reed Wash & 380 & 734 & $>263$ & 1,345 & 35 & 1,314 & 1,314 & 1,314 \\
\hline Adobe Creek & 330 & 846 & $>303$ & 1,549 & 17 & 2,706 & 2,706 & 2,706 \\
\hline Leach Creek & 370 & 754 & $>270$ & 1,381 & 20 & 2,300 & 2,300 & 2,300 \\
\hline Indian Wash & 600 & 465 & $>167$ & 852 & 48 & 958 & 958 & 958 \\
\hline \multicolumn{9}{|c|}{ RAZORBACK SUCKER } \\
\hline Salt Creek & 330 & 770 & 846 & $>303$ & 23 & 2,000 & 2,000 & 2,000 \\
\hline Reed Wash & 380 & 668 & 734 & $>263$ & 35 & 1,314 & 1,314 & 1,314 \\
\hline Adobe Creek & 330 & 770 & 846 & $>303$ & 17 & 2,706 & 2,706 & 2,706 \\
\hline Leach Creek & 370 & 687 & 754 & $>270$ & 20 & 2,300 & 2,300 & 2,300 \\
\hline Indian Wash & 600 & 423 & 465 & $>167$ & 48 & 958 & 958 & 958 \\
\hline
\end{tabular}

Table 34. Hazard assessment of vanadium and zinc in water samples collected from five streams in the Grand Valley to three life stages of Colorado squawfish and razorback suckers

[ $\mu \mathrm{g} / \mathrm{L}$, micrograms per liter; hazard assessment is equal to BEC/EEC, where BEC is the biologically effective concentration and EEC is the estimated environmental concentration of a contaminant; a hazard assessment greater than 5,000 is low risk, 1,000 to 5,000 is uncertain risk, 100 to 1,000 is moderate risk, and less than 100 is high risk]

\begin{tabular}{|c|c|c|c|c|c|c|c|c|}
\hline \multirow[b]{3}{*}{ Stream } & \multicolumn{4}{|c|}{ Vanadium } & \multicolumn{4}{|c|}{ Zinc } \\
\hline & \multirow{2}{*}{$\begin{array}{c}\text { Maximum } \\
\text { water } \\
\text { concentration } \\
(\mu g /)\end{array}$} & \multicolumn{3}{|c|}{ BEC/EEC for the three life stages } & \multirow{2}{*}{$\begin{array}{c}\text { Maximum } \\
\text { water } \\
\text { concentration } \\
(\mu g / L)\end{array}$} & \multicolumn{3}{|c|}{ BEC/EEC for the three life stages } \\
\hline & & $\begin{array}{l}\text { Less than } \\
99 \text { days old } \\
\text { (swim-up) }\end{array}$ & $\begin{array}{c}99 \text { to } \\
115 \text { days old }\end{array}$ & $\begin{array}{l}193 \text { to } \\
207 \text { days old }\end{array}$ & & $\begin{array}{l}\text { Less than } \\
99 \text { days old } \\
\text { (swim-up) }\end{array}$ & $\begin{array}{c}99 \text { to } \\
115 \text { days old }\end{array}$ & $\begin{array}{c}193 \text { to } \\
207 \text { days old }\end{array}$ \\
\hline \multicolumn{9}{|c|}{ COLORADO SQUAWFISH } \\
\hline Salt Creek & 5 & 1,560 & 760 & 840 & 10 & 170 & 420 & 1,200 \\
\hline Reed Wash & 5 & 1,560 & 760 & 840 & 10 & 170 & 420 & 1,200 \\
\hline Adobe Creek & 5 & 1,560 & 760 & 840 & 20 & 85 & 210 & 600 \\
\hline Leach Creek & 4 & 1,950 & 950 & 1,050 & 30 & 57 & 140 & 400 \\
\hline Indian Wash & 9 & 867 & 422 & 467 & 20 & 85 & 210 & 600 \\
\hline \multicolumn{9}{|c|}{ RAZORBACK SUCKER } \\
\hline Salt Creek & 5 & 1,740 & 800 & 640 & 10 & 400 & 640 & 1,500 \\
\hline Reed Wash & 5 & 1,740 & 800 & 640 & 10 & 400 & 640 & 1,500 \\
\hline Adobe Creek & 5 & 1,740 & 800 & 640 & 20 & 200 & 320 & 750 \\
\hline Leach Creek & 4 & 2,180 & 1,000 & 800 & 30 & 133 & 213 & 500 \\
\hline Indian Wash & 9 & 967 & 444 & 356 & 20 & 200 & 320 & 750 \\
\hline
\end{tabular}


Table 35. Geometric mean and maximum concentrations of the 1984 National Contaminant Biomonitoring Program (NCBP) for selected organochlorine pesticides and polychlorinated biphenyls (PCB's)

[Concentrations in micrograms per gram wet weight; NCBP data from Schmitt and others (1990)]

\begin{tabular}{lcc}
\hline Compound & $\begin{array}{c}\text { NCBP } \\
\text { geometric } \\
\text { mean } \\
\text { concentration }\end{array}$ & $\begin{array}{c}\text { NCBP } \\
\text { maximum } \\
\text { concentration }\end{array}$ \\
\hline p,p'-DDE & 0.19 & 4.74 \\
p,p'-DDD & .06 & 2.55 \\
p,p'-DDT & .03 & 1.79 \\
Total DDT & .26 & 9.08 \\
Heptachlor & .01 & .29 \\
Dieldrin & .04 & 1.39 \\
Toxaphene & .14 & 8.2 \\
cis-Chlordane & .03 & .66 \\
trans-Chlordane & .02 & .35 \\
cis-Nonachlor & .02 & .45 \\
trans-Nonachlor & .03 & 1.0 \\
Oxychlordane & .01 & .29 \\
Total PCB's & .39 & 6.7 \\
\hline
\end{tabular}

The toxaphene concentration of $0.82 \mu \mathrm{g} / \mathrm{g}$ wet weight in the flannelmouth sucker from Dry Creek (site DRY1) was almost six times greater than the 1984 NCBP geometric mean concentration (table 35). Mayer and Mehrle (1977) reported that toxaphene residues in excess of 0.4 to $0.6 \mu \mathrm{g} / \mathrm{g}$ wet weight might be hazardous to fish health, and Eisler and Jacknow (1985) indicated that such concentrations indicate possible environmental contamination. The toxaphene concentration of $0.82 \mu \mathrm{g} / \mathrm{g}$ wet weight exceeded these two guidelines. However, the toxaphene concentration was less than the U.S. Food and Drug Administration's action level of $5.0 \mu \mathrm{g} / \mathrm{g}$ wet weight in fish that is considered hazardous for human consumption (U.S. Environmental Protection Agency, 1980).

Bile samples were collected from fish and analyzed to provide an indication of polycyclic aromatic hydrocarbon (PAH) exposure. Bile is a sensitive indicator for assessing the exposure of fish to PAH's (McDonald and others, 1991). High concentrations of PAH metabolites in bile indicated actual exposure, and high concentrations of PAH's in sediment indicated a potential for exposure (Johnston and Baumann, 1989).
Ten fish-bile samples collected from stream and river sites in and adjacent to the Uncompahgre Project, plus one fish-bile sample collected from Crawford Reservoir, were analyzed for 24 PAH's. Two fishbile samples collected from streams in the Grand Valley area and one fish-bile sample from Highline Reservoir also were analyzed for PAH's. All PAH data are listed in table 39 in Butler and others (1994). One of the compounds included in the PAH analysis was a-benzopyrene, a known carcinogen (Eisler, 1987b). Eisler (1987b) reported that selenium can be an effective inhibitor of PAH-induced tumor development. Eisler (1987b) also reported that no criteria or standards have been established for PAH's by any regulatory agency for the protection of sensitive species of aquatic organisms or wildlife. The highest concentrations of PAH's, including a-benzopyrene, in fish bile collected for this study were in a white sucker sample collected from the North Fork of the Gunnison River near Paonia (site NFK3 in fig. 45).

\section{Selenium Concentrations in Migratory Birds and Their Food Items}

\section{Uncompahgre Project Area Wetlands}

Migratory birds were sampled from wetlands during 1991 and 1992. Wetlands were geographically divided into those in the irrigated area of the Uncompahgre Project and those adjacent to the Uncompahgre Project (fig. 52). Sites in the Uncompahgre Project are: Markley Pond (site MKP), Gretts Pond (site GTP), Vo-Tech marsh (site VT), Sweitzer Lake (site SWL), Brozina Pond (site BZP), and a drainage at G Road (site UNGR) (fig. 52). The wetland sites adjacent to the Uncompahgre Project are: Ferrier Pond (site FRP), Fruitgrowers Reservoir (site FGR), St. George Pond (site SGP), and Alkali Reservoir (site AKR) (fig. 52).

Selenium concentrations in aquatic-plant and algae samples collected from the Uncompahgre Project area wetlands ranged from $4.2 \mu \mathrm{g} / \mathrm{g}$ dry weight at site GTP (fig. 52) to $12 \mu \mathrm{g} / \mathrm{g}$ dry weight at site BZP (Butler and others, 1994, table 32). Fathead minnows had selenium concentrations that ranged from $36 \mu \mathrm{g} / \mathrm{g}$ dry weight at site GTP to $59 \mu \mathrm{g} / \mathrm{g}$ dry weight at site BZP. An aquatic-invertebrate sample collected from site MKP contained $32 \mu \mathrm{g} / \mathrm{g}$ dry weight selenium. These selenium concentrations greatly exceeded $3 \mu \mathrm{g} / \mathrm{g}$ dry weight, a dietary selenium 

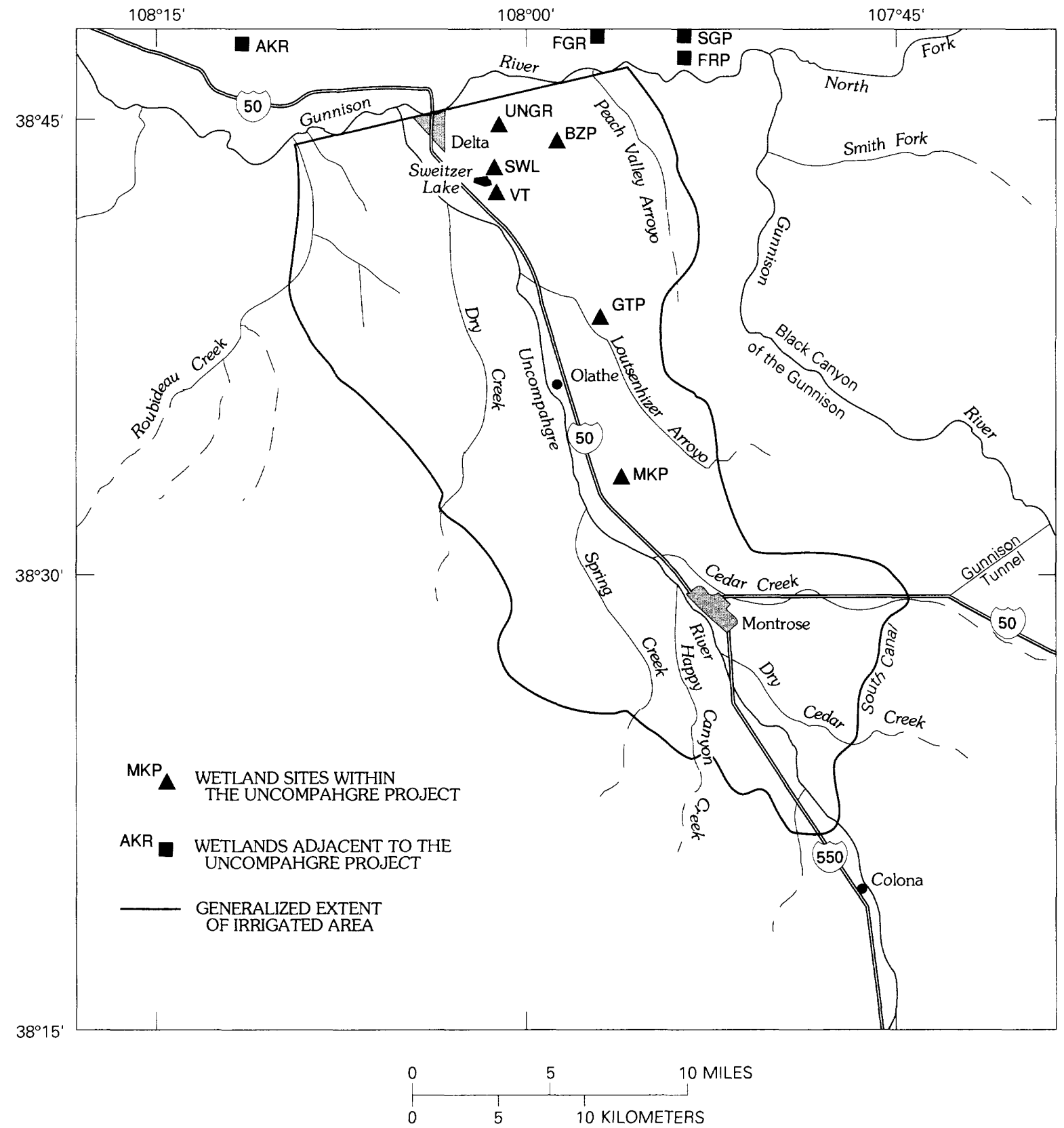

Figure 52. Location of sampling sites at wetlands in the Uncompahgre Project area.

concentration of concern for protection of fish and bird species (Lemly and Smith, 1987; Lemly 1993). The selenium concentrations in fathead minnows greatly exceeded the concentrations reported in laboratory studies in which fathead minnows showed adverse effects, especially reproductive failure (Ogle and Knight, 1989; Schultz and Hermanutz, 1990).

Selenium concentrations in bird-liver and -egg samples (table 36) exceeded normal concentrations in some samples and were in the range of potentially toxic concentrations in other samples. Skorupa and Ohlendorf (1991) considered normal selenium concentrations for bird eggs to average less than or equal to $3 \mu \mathrm{g} / \mathrm{g}$ dry weight and stated that there was a high risk of adverse biological effects occurring with a population mean of greater than or equal to $20 \mu \mathrm{g} / \mathrm{g}$ dry weight selenium in bird eggs. Skorupa and Ohlendorf (1991) also advised that a population mean selenium concentration between 3 and $20 \mu \mathrm{g} / \mathrm{g}$ dry weight in bird eggs needed 
further field studies of reproductive performance to assess biological risk. The geometric mean selenium concentration for eggs for all bird species collected within the Uncompahgre Project was $14.7 \mu \mathrm{g} / \mathrm{g}$ dry weight (geometric deviation 1.8) (table 36). The geometric mean selenium concentration in five avocet eggs collected from Brozina Pond (site BZP) was $41.9 \mu \mathrm{g} / \mathrm{g}$ dry weight (geometric deviation 1.1). Selenium concentrations of that magnitude were associated with a 5-percent incidence of teratogenic effects (J.P. Skorupa and others, U.S. Fish and Wildlife Service, written commun., 1993). A liver from an immature avocet from site BZP contained $98 \mu \mathrm{g} / \mathrm{g}$ dry weight selenium, greatly exceeding $30 \mu \mathrm{g} / \mathrm{g}$ dry weight selenium, a concentration associated with a high risk of adverse biological effects (J.P. Skorupa and others, U.S. Fish and Wildlife Service, written commun., 1993). Geometric mean selenium concentrations in coot, killdeer, and blackbird egg samples collected in the Uncompahgre Project were in the range of concern of 3 to $20 \mu \mathrm{g} / \mathrm{g}$ dry weight (Skorupa and Ohlendorf, 1991).
As in samples collected from wetlands located in the irrigated area of the Uncompahgre Project, selenium concentrations in bird-livers and -egg samples from wetlands adjacent to the project (table 36 ) exceeded normal concentrations in some samples and were in the range of adverse health effects and reproductive failure in other samples. St. George Pond (site SGP in fig. 52) and Ferrier Pond (site FRP) contained some of the highest selenium concentrations in biota samples collected for this study. One aquaticplant sample collected from Ferrier Pond contained $68 \mu \mathrm{g} / \mathrm{g}$ dry weight selenium (Butler and others, 1994 , table 33), which is more than 20 times greater than the recommended dietary guideline of $3 \mu \mathrm{g} / \mathrm{g}$ dry weight selenium for the protection of fish and wildlife resources (Lemly and Smith, 1987; Lemly, 1993). Two fathead minnow samples collected at site SGP contained 72 and $110 \mu \mathrm{g} / \mathrm{g}$ dry weight selenium (table 36 ), which not only greatly exceeded the dietary guideline for protection of birds, but also were much greater than the range of 6 to $8 \mu \mathrm{g} / \mathrm{g}$ dry weight associated with adverse health effects and reproductive failure in fathead minnows (Ogle and Knight, 1989; Schultz and Hermanutz, 1990).

Table 36. Statistical summary of selenium concentrations in selected bird-food and bird-tissue samples collected during 1991-92 from wetlands in the Uncompahgre Project, wetlands adjacent to the Uncompahgre Project, and wetlands in the Grand Valley

[Concentrations in micrograms per gram dry weight; N, number of samples; GM, geometric mean; GD, geometric deviation; --, no data]

\begin{tabular}{|c|c|c|c|c|c|c|c|c|c|}
\hline \multirow[b]{2}{*}{ Statistic } & \multicolumn{5}{|c|}{ Bird-food samples } & \multicolumn{4}{|c|}{ Bird-tissue samples } \\
\hline & $\begin{array}{l}\text { Aquatic } \\
\text { plants }\end{array}$ & $\begin{array}{c}\text { Aquatic } \\
\text { invertebrates }\end{array}$ & $\begin{array}{l}\text { Fathead } \\
\text { minnows }\end{array}$ & $\begin{array}{l}\text { Green } \\
\text { sunfish }\end{array}$ & Carp & $\begin{array}{l}\text { Whole } \\
\text { body }\end{array}$ & Liver & Breast & Egg \\
\hline \multicolumn{10}{|c|}{ WITHIN THE UNCOMPAHGRE PROJECT } \\
\hline $\mathbf{N}$ & 5 & 1 & 4 & 1 & 0 & 33 & 1 & 0 & 34 \\
\hline GM & 7.3 & -- & 48.7 & -- & -- & 13.7 & -- & -- & 14.7 \\
\hline GD & 1.6 & -- & 1.2 & -- & -- & 1.7 & -- & -- & 1.8 \\
\hline MAXIMUM & 12 & 32 & 59 & 55 & -- & 39 & 98 & - & 47.6 \\
\hline MINIMUM & 4.2 & 32 & 36 & 55 & -- & 4.2 & 98 & -- & 7.0 \\
\hline \multicolumn{10}{|c|}{ ADJACENT TO THE UNCOMPAHGRE PROJECT } \\
\hline $\mathbf{N}$ & 2 & 0 & 2 & 0 & 2 & 13 & 14 & 5 & 25 \\
\hline GM & 23.7 & -- & 91.2 & -- & 14.6 & 18.3 & 30.3 & 20.4 & 13.4 \\
\hline GD & 4.4 & -- & 1.3 & -- & 1.1 & 1.5 & 1.5 & 1.9 & 1.6 \\
\hline MAXIMUM & 68 & -- & 110 & -- & 15 & 43 & 59 & 47 & 24 \\
\hline MINIMUM & 8.3 & -- & 72 & -- & 14 & 10 & 17 & 10 & 4.1 \\
\hline \multicolumn{10}{|c|}{ GRAND VALLEY } \\
\hline$N$ & 0 & 0 & 0 & 0 & 0 & 10 & 11 & 0 & 20 \\
\hline GM & -- & - & -- & -- &.- & 10.0 & 23.9 & -- & 6.7 \\
\hline GD & -- & -- & -- & -- & -- & 1.9 & 1.5 & -- & 1.5 \\
\hline MAXIMUM & -. & -- & -- & -- & -- & 18 & 37 & -- & 17 \\
\hline MINIMUM & -- & -- & -- & - & -- & 2.3 & 10 & -- & 3.9 \\
\hline
\end{tabular}


The geometric mean selenium concentration for 25 bird eggs (all species) collected from wetlands adjacent to the Uncompahgre Project was $13.4 \mu \mathrm{g} / \mathrm{g}$ dry weight (geometric deviation 1.6) (table 36). Geometric mean selenium concentrations in coot, yellow-headed blackbird, and grebe eggs collected in adjacent wetlands also were in the range of concern of 3 to $20 \mu \mathrm{g} / \mathrm{g}$ dry weight (Skorupa and Ohlendorf, 1991).

\section{Grand Valley Wetlands}

Bird samples were collected from six Grand Valley wetland sites: Romig Pond (site RMP), Reid Pond (site RDP), Thompson Pond (site TMP), Mack Wash (site MWP), Reed Wash (site RWEB), and 19 and $M$ Roads (site 19M) (fig. 53). The geometric mean selenium concentration for $20 \mathrm{egg}$ samples of all bird species collected in Grand Valley wetlands was $6.7 \mu \mathrm{g} / \mathrm{g}$ dry weight (geometric deviation 1.5 ) (table 36), which is one-half of the geometric mean selenium concentrations for eggs collected from the Uncompahgre Project area, but the mean is in the range of concern. The geometric mean selenium concentration in three avocet eggs from Thompson Pond (site TMP) was $5.9 \mu \mathrm{g} / \mathrm{g}$ dry weight (geometric deviation 1.2), which was considerably lower than the geometric mean selenium concentration for avocet eggs from the Uncompahgre Project area (from site BZP). The geometric mean selenium concentrations for red-winged blackbird eggs of $7.3 \mu \mathrm{g} / \mathrm{g}$ dry weight (geometric deviation 1.4) and for mallard eggs of $6.6 \mu \mathrm{g} / \mathrm{g}$ dry weight (geometric deviation 1.6) were in the range of concern ( 3 to $20 \mu \mathrm{g} / \mathrm{g}$ dry weight) that would need further field reproductive studies to determine the biological risk (Skorupa and Ohlendorf, 1991). The geometric mean selenium concentration for seven mallard liver samples collected from Grand Valley wetlands was $23.4 \mu \mathrm{g} / \mathrm{g}$ dry weight (geometric deviation 1.5), also in the range of selenium concentrations in bird livers that would need additional investigation to assess biological risk.

\section{Other Trace-Constituent Concentrations in Birds and Their Food Items}

Mercury concentrations in aquatic-plant, aquatic-invertebrate, and fathead minnow samples collected within the irrigated area of the
Uncompahgre Project at Markley Pond (site MKP), Gretts Pond (site GTP), and Brozina Pond (BZP) (fig. 52) were less than the $0.1-\mu \mathrm{g} / \mathrm{g}$ wet-weight concentration that Eisler (1987a) recommended for the protection of sensitive consumer bird species. Mercury concentrations in all bird eggs collected from the Uncompahgre Project area and in the Grand Valley were less than the $0.9-\mu \mathrm{g} / \mathrm{g}$ wet-weight concentration associated with adverse behavioral effects in mallards (Heinz, 1979). The highest mercury concentration in a bird-egg sample was $1.7 \mu \mathrm{g} / \mathrm{g}$ dry weight in a piedbilled grebe egg collected from Fruitgrowers Reservoir (site FGR in fig. 52).

Mercury concentrations in bird-liver samples collected from the Uncompahgre Project area and the Grand Valley were less than the $20-\mu \mathrm{g} / \mathrm{g}$ wet-weight concentration in bird soft tissues that Finley and others (1979) considered to be hazardous to bird health. The highest mercury concentration in a bird-liver sample was in a pied-billed grebe liver from Ferrier Pond (site FRP) that had a concentration of $15.6 \mu \mathrm{g} / \mathrm{g}$ dry weight $(4.0 \mu \mathrm{g} / \mathrm{g}$ wet weight). Two western grebe samples collected adjacent to the Uncompahgre Project from Fruitgrowers Reservoir (site FGR) had mercury concentrations of $6.6 \mu \mathrm{g} / \mathrm{g}$ dry weight $(2.0 \mu \mathrm{g} / \mathrm{g}$ wet weight) and $1.98 \mu \mathrm{g} / \mathrm{g}$ dry weight $(0.49 \mu \mathrm{g} / \mathrm{g}$ wet weight) (Butler and others, 1994, table 33). Eisler (1987a) reported that mercury concentrations in birds were highest in species that eat fish or other birds. Eisler (1987a) also reported that mercury concentrations greater than $1.0 \mathrm{mg} / \mathrm{kg}$ $(\mu \mathrm{g} / \mathrm{g})$ fresh weight in any bird sample often were associated with proximity to human use of mercury and that the effect of mercury residues in birds is not fully understood.

Arsenic concentrations in all bird-liver samples collected from the Uncompahgre Project area and from the Grand Valley were less than the range 2- to $10-\mu \mathrm{g} / \mathrm{g}$ wet-weight concentration that Eisler (1988) indicated as being elevated. Boron concentrations in aquatic-plant samples collected from Markley Pond (site MKP) and Gretts Pond (site GTP in fig. 52) were less than the $30-\mu \mathrm{g} / \mathrm{g}$ wet-weight concentration known to adversely affect waterfowl growth (Eisler, 1988). Most bird tissue samples collected from the Uncompahgre Project area and from the Grand Valley contained boron concentrations that were less than the analytical reporting limits. 


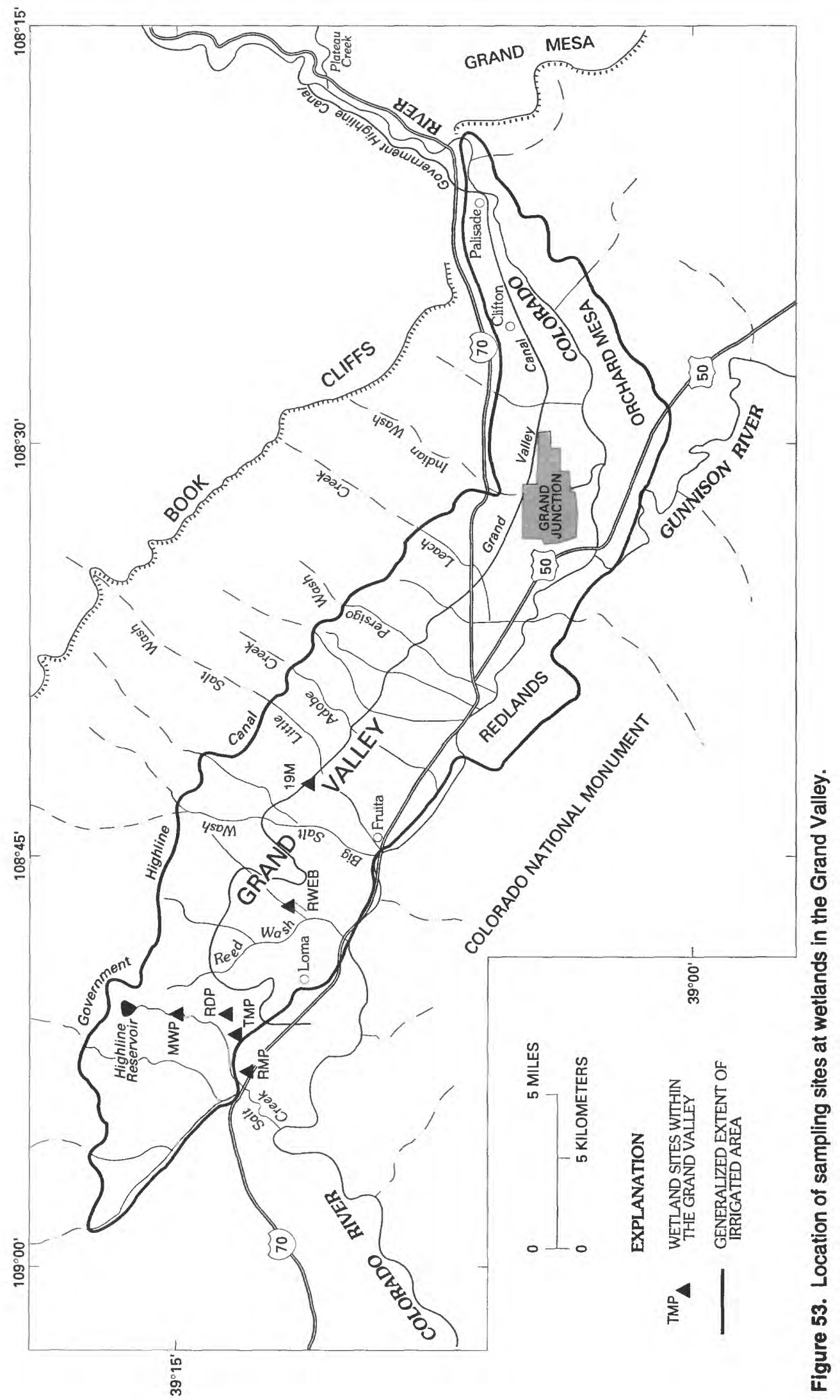


Cadmium concentrations in all bird samples collected from the Uncompahgre Project area and from the Grand Valley were less than the $2-\mu \mathrm{g} / \mathrm{g}$ wet-weight concentration for whole-body vertebrates, or the $10-\mu \mathrm{g} / \mathrm{g}$ wet-weight concentration for bird livers that Eisler (1985) reported was evidence of probable cadmium contamination. Eisler (1986) reported that chromium concentrations greater than $4 \mu \mathrm{g} / \mathrm{g}$ dry weight in organs and tissues of fish and wildlife are indicative of chromium contamination. For samples collected in the Uncompahgre Project, the chromium concentrations of $6.3 \mu \mathrm{g} / \mathrm{g}$ dry weight in a snipe egg from Markley Pond (site MKP in fig. 52) and $4.8 \mu \mathrm{g} / \mathrm{g}$ dry weight in a Wilson's phalarope whole-body sample from Brozina Pond (site BZP) exceeded the guideline for chromium. Chromium concentrations in whole-body killdeer samples collected at Sweitzer Lake (site SWL) ranged from 3.6 to $3.9 \mu \mathrm{g} / \mathrm{g}$ dry weight and were slightly less than the guideline for chromium contamination. Adjacent to the Uncompahgre Project, a chromium concentration of $4.1 \mu \mathrm{g} / \mathrm{g}$ dry weight in a yellow-headed blackbird whole-body sample exceeded the guideline of $4 \mu \mathrm{g} / \mathrm{g}$ dry weight. In the Grand Valley, a widgeon liver sample from Reid Pond (site RDP in fig. 53) had a chromium concentration of $19.6 \mu \mathrm{g} / \mathrm{g}$ dry weight.

\section{Incubation Studies of Bird Eggs}

During 1991, an attempt was made to monitor nest success at a few wetland sites in the Uncompahgre Project area and in the Grand Valley. The monitoring had limited success because, at many sites, eggs in ground nests were eaten by predators before the eggs reached full term. Additionally, nests could not be visited on a daily basis, and, because of rapid dispersal of the young, visual inspection of hatchlings for external deformities or to document hatching success was almost impossible. Because of these problems, eggs were brought from the field into the laboratory and incubated for the 1992 bird study.

Bird eggs were collected from 10 sites in the Uncompahgre Project area and from 6 sites in the Grand Valley. Bird eggs were either candled or, if several eggs were collected from the same nest, one egg was cracked open and a hatching date projected. The egg contents were saved in an acid-cleansed jar and, depending on the species, either kept separate or composited with other egg contents from the same nest for trace-constituent analysis.
Species collected and incubated included yellow-headed and red-winged blackbirds, American coots, cinnamon teal, mallards, killdeer, American avocets, and common snipe. Because of equipment limitations, all eggs collected were placed in the same incubator. Temperature and humidity were kept constant throughout the incubation period, and the eggs were automatically turned twice a day.

Hatching success for all eggs placed in the incubator was 68 percent. Hatching success for eggs incubated from the Uncompahgre Project area was 78 percent and for eggs incubated from the Grand Valley was 42 percent. Because of the large number of variables that can affect hatching success, these percentages are not necessarily representative of the overall hatching success in the study area.

The primary reason for collecting and incubating eggs was to inspect visually each hatchling for any obvious deformities. Sixty-five eggs were incubated during the study period, and only one bird, a red-winged blackbird from Mack Wash Pond (site MWP), had any visual deformities. This bird had fused toes on his left foot, which possibly could be attributed to selenium toxicity (Ohlendorf and others, 1988) or to improper incubator temperature for that species (Stromberg, 1975). The whole-body selenium concentration in that bird was $8 \mu \mathrm{g} / \mathrm{g}$ dry weight, which is slightly higher than the geometric mean of $7.3 \mu \mathrm{g} / \mathrm{g}$ dry weight for all red-winged blackbirds collected at Mack Wash Pond, but is in the range of selenium concentrations ( 3 to $20 \mu \mathrm{g} / \mathrm{g}$ dry weight) that indicates further field reproductive studies are needed to determine biological risk (Skorupa and Ohlendorf, 1991).

\section{Field Observations at Wetland Sites}

General field observations were conducted at each of the wetland sites on each visit. These observations included recording the number and species of birds observed at each of the wetland sites. Most of the ponds in the study areas were used extensively during spring and fall migrations. Wetland use during the nesting season was limited by the pond size. Waterfowl that used the ponds displayed aggressive behavior, tending to be territorial because of the limited amount of suitable nesting habitat. 
At two sites in the Uncompahgre Project area, Ferrier Pond and Markley Pond (sites FRP and MKP in fig. 52), a detailed study of the hatching success of yellow-headed blackbirds was conducted in 1992. Initially, American coots were going to be included in the hatching success study; however, they rarely nested successfully.

On May 20, 1992, 118 active yellow-headed blackbird nests were located at Ferrier Pond. On May 23, 1992, the observers returned to Ferrier Pond and marked 25 full clutch (four-egg) nests from random locations around the pond for continued observation. On June 2, 1992, 10 days after first marking the nests, each nest was revisited, and the eggs in 23 of 25 nests had hatched. One nest had been destroyed, and one nest still contained four eggs. Each of the young, which varied in age from 1 to 12 days, were inspected in the field for any deformities or abnormalities. No deformities were found on any yellow-headed blackbirds from Ferrier Pond. After inspection, each prefledgling was returned to its nest. The site was revisited on June 8, 1992, and once again, each nest was visited and data recorded. There were many fledglings scattered throughout the cattails. The birds had fledged completely from 10 of the nests. Three nests had three prefledglings still in the nest. Six fledglings were collected for trace-constituent analysis, including one full-term prefledgling found dead in the nest. These birds were analyzed as wholebody samples. The birds were prepared for analysis by removing all feathers, legs, and beak. Selenium concentrations in these six birds ranged from $10 \mu \mathrm{g} / \mathrm{g}$ dry weight in one live bird to $43 \mu \mathrm{g} / \mathrm{g}$ dry weight in the prefledgling found dead in its nest. The appearance of the dead prefledgling indicated it was very near fledging. The bird showed no external abnormalities or deformities, but had a selenium concentration almost three times higher than the geometric mean of $16.1 \mu \mathrm{g} / \mathrm{g}$ dry weight selenium (geometric deviation 1.6) for the other five live fledglings collected from this site.

Of the 25 yellow-headed blackbird nests monitored at Ferrier Pond, one contained addled eggs. Two young were fledged from this nest, but two unhatched eggs remained. These two eggs were collected and analyzed. The selenium concentration of the contents of these two eggs was $13 \mu \mathrm{g} / \mathrm{g}$ dry weight, which is the same as the geometric mean selenium concentration of $13 \mu \mathrm{g} / \mathrm{g}$ dry weight for the other three egg samples (consisting of two eggs each) collected from this site. This selenium concentration was in the range of concern of 3 to $20 \mu \mathrm{g} / \mathrm{g}$ dry weight that, according to Skorupa and Ohlendorf (1991), would need further field studies to assess biological risk.

Adult coots commonly were seen at Ferrier Pond. On June 2, 1992, 12 coots were seen on the pond. Over the period of the detailed bird-monitoring study (May 20, 1992, to July 6, 1992), four coot nests were located on the pond. Egg samples were collected from three of the nests. The geometric mean selenium concentration of the three samples of coot eggs was $18.6 \mu \mathrm{g} / \mathrm{g}$ dry weight (geometric deviation 1.1), which was in the range of concern (Skorupa and Ohlendorf, 1991). From two of the coot nests from which eggs were collected and selenium concentrations determined, six eggs were incubated to full term. No external deformities were detected in these hatchlings. The geometric mean selenium concentration for the combined two samples of coot hatchlings was $19.8 \mu \mathrm{g} / \mathrm{g}$ dry weight (geometric deviation 1.2). No young coots were observed during 1992 on Ferrier Pond, even though coots were successfully hatched in the laboratory.

A study similar to the one conducted at Ferrier Pond also was conducted at Markley Pond (site MKP in fig. 52) from May to July 1992. This pond receives surface runoff from agricultural lands above the pond and from shallow ground water discharging from Mancos Shale. Markley Pond was chosen because several hunters who leased this pond noticed dead birds on or near the pond and attributed mortality to causes other than hunting-induced injuries.

On May 19, 1992, a prefledgling mallard was found dead in a slough that flows into Markley Pond. This prefledgling had recently died and appeared normal with no visible trauma, deformities, or abnormalities. This sample contained a whole-body selenium concentration of $26 \mu \mathrm{g} / \mathrm{g}$ dry weight. A second fresh prefledgling mallard was found dead in this same general area on May 27, 1992. This bird, much like the first bird, had no visible signs of trauma, deformities, or abnormalities and was found floating among the cattails. This sample contained a wholebody selenium concentration of $27 \mu \mathrm{g} / \mathrm{g}$ dry weight.

Red-winged blackbirds also were studied during 1992 at Markley Pond. However, most red-winged blackbird nests were not directly associated with the pond and were in remote wetland areas adjoining the pond. Selenium concentrations in red-winged blackbird eggs and whole-body prefledglings ranged from 7.1 to $19 \mu \mathrm{g} / \mathrm{g}$ dry weight. The geometric mean 
selenium concentration was $13.0 \mu \mathrm{g} / \mathrm{g}$ dry weight (geometric deviation 1.4) for three egg samples and $10.6 \mu \mathrm{g} / \mathrm{g}$ dry weight (geometric deviation 1.6 ) for the five prefledglings sampled.

On May 27, 1992, 35 active yellow-headed blackbird nests were found scattered throughout the cattails on the south and west sides of Markley Pond. Twenty nests were flagged using the same method that was used at Ferrier Pond. Eight nests were located that had full clutches of four eggs, and all other nests had zero to three eggs. On June 2, 1992, most of the nests that previously had zero to three eggs had full clutches of four eggs. Four of the nests had new hatchlings. By June 9, 1992, all marked nests had been pulled down, and eggs and young eaten by raccoons.

On June 24, 1992, 10 coots were observed on Markley Pond, and 8 coot nests were located. Coot eggs were collected from four of the nests, and the contents analyzed for trace constituents. The geometric mean selenium concentration of the four egg samples was $24.4 \mu \mathrm{g} / \mathrm{g}$ dry weight (geometric deviation 1.5), which exceeded the concentration range of 3 to $20 \mu \mathrm{g} / \mathrm{g}$ dry weight associated with biological risk (Skorupa and Ohlendorf, 1991). Two dead coot hatchlings were found in close proximity to the nest where one of the egg samples was collected. This egg sample contained a selenium concentration of $30.3 \mu \mathrm{g} / \mathrm{g}$ dry weight. The combined whole-body sample of the two dead coot hatchlings had a selenium concentration of $19 \mu \mathrm{g} / \mathrm{g}$ dry weight.

Two additional coot egg samples were brought back to the laboratory on June 24,1992 , and placed in the incubator. One of the two coot eggs was cheeping at the time it was picked up, so was assumed to be in a later stage of development. Both eggs were opened on June 29,1992 , because they had not yet hatched, and both embryos were dead. The two embryos had reached full term and appeared normal with no external deformities. The selenium concentration of the two embryos (combined into one sample) was $39 \mu \mathrm{g} / \mathrm{g}$ dry weight.

During subsequent visits, no prefledgling coots were observed on the pond. Adult coots were seen, but only one of the eight nests discovered on June 24,1992 , was found on a subsequent visit on July 6 . This nest contained three eggs, the same number of eggs as when discovered on June 24. In addition, no other prefledgling waterfowl were seen or collected from Markley Pond.

\section{Water and Bottom-Sediment Bioassays}

After reviewing the selenium concentrations in water from the 1991 sampling, five sampling sites on washes in the Grand Valley were selected to conduct toxicity tests. The five streams sampled had some of the highest selenium concentrations in the Grand Valley. The streams were Salt Creek (site SC), Reed Wash (site RW1), Adobe Creek (site AC1), Leach Creek (site LC1), and Indian Wash (site IW) (fig. 46). Water and bottom-sediment samples were collected for bioassays in March 1992 and sent to the U.S. Environmental Protection Agency in Denver, Colo., for analysis. Chronic tests on larval fathead minnows and daphnia (Ceriodaphnia dubia) were conducted according to methods described by Weber and others (1989) and according to guidelines by the U.S. Environmental Protection Agency National Pollutant Discharge Elimination System (NPDES) Whole Effluent Toxics Control Program of December 1990. Daphnia and 3-day-old fathead minnows were exposed to the water samples using dilutions that included five selenium concentrations (a control, 12.5 percent, 25 percent, 50 percent, and 100 percent of the original sample concentration). Samples from Leach Creek and Indian Wash did not have tests at the 12.5-percent concentration because of limited sample quantity. Bottomsediment samples were sent to Technology Applications, Inc., in Cincinnati, Ohio, for testing with amphipods (Hyallela azteca) and fathead minnow embryos.

\section{Water Bioassays}

Water bioassays using Ceriodaphnia exposed to water samples from the five test sites indicated no significant differences between the number of young produced in control solutions and in test solutions. There were no significant differences in the fathead minnow growth in controls compared to the test solutions from Salt Creek, Reed Wash, Adobe Creek, and Indian Wash. However, growth and survival of fathead minnows in bioassays using water from Leach Creek indicated potential chronic toxicity. When survival of fathead minnows was analyzed, the lowest observed effect concentration (LOEC) for Leach Creek water was 100 percent (the undiluted concentration) and the no-observed effect concentration (NOEC) was 50-percent 
concentration. When growth was analyzed, the LOEC was 50-percent concentration and the NOEC was 25-percent concentration.

The U.S. Environmental Protection Agency (1987) reported that freshwater aquatic organisms would not be adversely affected if the 4-day average selenium concentration in the water did not exceed $5 \mu \mathrm{g} / \mathrm{L}$ more than once every 3 years on the average, and if the 1-hour average concentration did not exceed $20 \mu \mathrm{g} / \mathrm{L}$ more than once every 3 years. All totalselenium concentrations in water samples in the five sites greatly exceeded these guideline concentrations (Butler and others, 1994, table 5). Although Reed Wash had the largest selenium concentration for the samples collected in March 1992 at the five sites (table 20), toxicity was reported only for the Leach Creek water sample. The presence of one or more contaminants, such as other trace constituents, salts, or pesticides, in addition to selenium, might have been responsible for the harmful environment in the Leach Creek sample.

\section{Bottom-Sediment Bioassays}

Two different bioassays were conducted on bottom-sediment samples. The first test was a 7-day growth and survival test using Hyallela. The only samples that had results different from the control were from Reed Wash and Adobe Creek. The sample from Reed Wash had a survival rate of 59 percent, and the sample from Adobe Creek had a survival rate of 43 percent. All other samples had a survival rate of greater than 70 percent. None of the mean dry weights (the value used to indicate growth) of Hyallela that were cultured on bottom-sediments samples were statistically different from the mean dry weights of Hyallela from the control samples.

The second test on bottom-sediment samples was a fathead minnow embryo-larval test, which was a first attempt at a new bottom-sediment exposure method using embryos. A volume of $25-\mathrm{mL}$ of bottom sediment from each of the five tributaries was placed in a container and covered by $100 \mathrm{~mL}$ of distilled water. The 24- to 48-hour-old embryos were placed on top of the bottom sediment. Hatch rate and survival rate for the control embryos and larvae were greater than 90 percent. All embryos exposed to the bottom sediments from the five streams were dead in less than 24 hours. The cause or causes of the fathead minnow embryo deaths are unknown.
Bottom-sediment samples from Salt Creek, Reed Wash, Adobe Creek, Leach Creek, and Indian Wash had total-selenium concentrations of $1.9,6.3$, $3.9,5.6$, and $16 \mu \mathrm{g} / \mathrm{g}$ (or $\mathrm{mg} / \mathrm{kg}$ ). Lemly and Smith (1987) indicated that a selenium concentration greater than or equal to $4 \mathrm{mg} / \mathrm{kg}$ was of concern to fish and birds because of possibilities of reproductive failure or mortality due to food-chain bioconcentration. Selenium concentrations in Reed Wash, Leach Creek, and Indian Wash exceeded this guideline. As in the water samples, other contaminants (including high salinity), as well as selenium, could be causing toxic effects in bottom sediments.

\section{BIOACCUMULATION OF SELENIUM}

Bioaccumulation is the uptake by aquatic organisms of chemicals from water directly or through consumption of food containing the chemicals. Numerous publications have addressed the subject of selenium bioaccumulation, including Lemly and Smith (1987), Ohlendorf (1989), Ohlendorf and others (1993), and Maier and Knight (1994). Selenium is bioaccumulated by aquatic organisms through two mechanisms: bioconcentration and biomagnification. Bioconcentration is the direct uptake of dissolved selenium across respiratory and epithelial membranes by passive or active processes. Biomagnification is the process in which higher trophic-level organisms accumulate selenium by ingesting and assimilating organo-selenium compounds synthesized by lower food-chain organisms (Maier and Knight, 1994). Biomagnification is the major pathway of selenium accumulation for higher trophic-level biota.

Data summarizing the bioaccumulation of selenium in the Uncompahgre Project area and in the Grand Valley are listed in table 37. Geometric mean selenium concentrations are listed in table 37 for water, bottom sediment, and several groups of biota. Because bird samples were collected only at wetlands, only water, bottom-sediment, and other biological samples collected at wetland sites were used to describe bioaccumulation in the study area. Selenium concentrations are expressed in micrograms per liter for water and micrograms per kilogram for bottom sediment and biota; both units are equivalent to parts per billion. 
Table 37. Geometric mean selenium concentrations in water, bottom-sediment, and biota samples from wetlands in the Uncompahgre Project, wetlands adjacent to the Uncompahgre Project, and wetlands in the Grand Valley

[Water concentrations in micrograms per liter; bottom-sediment and biota concentrations in micrograms per kilogram (both units are equivalent to parts per billion); number in brackets is the number of samples; --, no data]

\begin{tabular}{lrrr}
\hline \multicolumn{1}{c}{$\begin{array}{c}\text { Sample } \\
\text { matrix }\end{array}$} & $\begin{array}{c}\text { Uncompangre } \\
\text { Project }\end{array}$ & $\begin{array}{c}\text { Adjacent to the } \\
\text { Uncompahgre } \\
\text { Project }\end{array}$ & $\begin{array}{c}\text { Grand } \\
\text { Valley }\end{array}$ \\
\hline Water & $4.7[5]$ & $10[1]$ & $7.4[4]$ \\
Bottom sediment & $27,400[2]$ & $-[0]$ & $17,700[2]$ \\
Aquatic plants & $7,300[5]$ & $23,700[2]$ & $--[0]$ \\
Aquatic inverterates & $32,000[1]$ & $--[0]$ & $--[0]$ \\
Fish, whole body & $49,900[5]$ & $33,700[4]$ & $13,000[2]$ \\
& & & \\
Bird, whole body & $13,700[33]$ & $18,300[13]$ & $10,000[10]$ \\
Bird liver & $98,000[1]$ & $30,300[14]$ & $23,900[11]$ \\
Bird breast & $--[0]$ & $20,400[5]$ & $--[0]$ \\
Bird egg & $14,700[34]$ & $13,400[25]$ & $6,700[20]$ \\
\hline
\end{tabular}

At wetlands adjacent to the Uncompahgre Project, the selenium concentration of the single water sample was $10 \mu \mathrm{g} / \mathrm{L}$, and, in whole-body fish samples, the geometric mean concentration was $33,700 \mu \mathrm{g} / \mathrm{kg}$ (table 37). These concentrations indicated a bioaccumulation factor of $3,370(33,700$ divided by 10 ) between fish and water. At wetlands in the Uncompahgre Project, the geometric mean selenium concentrations were $4.7 \mu \mathrm{g} / \mathrm{L}$ for water and $49,900 \mu \mathrm{g} / \mathrm{kg}$ for whole-body fish, indicating a bioaccumulation factor of 10,600 . For wetlands in the Grand Valley, geometric mean selenium concentrations were $7.4 \mu \mathrm{g} / \mathrm{L}$ for water and $13,000 \mu \mathrm{g} / \mathrm{kg}$ for whole-body fish (table 37 ), indicating a bioaccumulation factor of 1,800 . Lemly and Smith (1987) reported that, where selenium in water has been concentrated from 100 to more than 30,000 times, fish were affected by chronic toxicity.

Bioaccumulation factors between bottom sediment and all biota matrices and among the successive biota trophic levels were much smaller than the bioaccumulation factors between water and bottom sediment and between water and biota. These data indicate that bottom sediment had accumulated selenium at ratios similar to biological tissues. The bioaccumulation factors among biota trophic levels are similar to the factors of 2 to 6 between successive trophic levels of a food chain reported by Lemly and Smith (1987, p. 9).
The three areas were quite similar regarding bioaccumulation factors, indicating that the relative rates of selenium accumulation between sample matrices are similar in the Uncompahgre Project area and in the Grand Valley, although selenium concentrations were somewhat variable among the areas. The highest bioaccumulation factor for selenium was about 20,900 between water and bird-liver concentrations for the irrigated area of the Uncompahgre Project.

\section{IMPLICATIONS FOR HUMAN HEALTH}

Selenium is a necessary nutritional component for humans in quantities from 50 to $200 \mu \mathrm{g} / \mathrm{d}$, depending on sex, age, and weight (National Academy of Sciences, 1983). However, too much intake of selenium can result in selenosis and can be detrimental to human health (Beath, 1962; Lo and Sandi, 1980; Shamberger, 1981; Levander, 1984; Combs and Combs, 1986).

Sweitzer Lake (site SWL in fig. 52), located near Delta in the Uncompahgre Project, was posted in 1977 by the Colorado Department of Health advising the public not to eat fish caught from the lake. Selenium concentrations in catfish-fillet samples collected in 1988-89 averaged $28 \mu \mathrm{g} / \mathrm{g}$ dry weight selenium (about $5.9 \mu \mathrm{g} / \mathrm{g}$ wet weight) (Butler and others, 1991), or about $167 \mu \mathrm{g}$ of selenium per ounce of fillet. The National Academy of Sciences (1980) considered an upper limit of $200 \mu \mathrm{g} / \mathrm{d}$ selenium to be safe for human intake. Levander (1984) suggested $500 \mu \mathrm{g} / \mathrm{d}$ selenium to be the safe upper limit for humans.

The highest selenium concentrations in fishfillet and bird-breast samples collected for the detailed study from the Uncompahgre Project area and from the Grand Valley are listed in table 38. The quantity of each sample that an adult human could safely consume without exceeding $200 \mu \mathrm{g} / \mathrm{d}$ selenium was computed and is listed in table 38 . The consumption limits do not account for selenium consumed in other food sources. Amounts of fillet or breast meat that could safely be consumed on a daily basis were quite small and ranged from $0.68 \mathrm{oz}$ of mallard breast taken from Ferrier Pond to $3.7 \mathrm{oz}$ of coot breast taken from Fruitgrowers Reservoir and to $3.7 \mathrm{oz}$ of catfish fillet taken from Highline Reservoir in the Grand Valley. Ferrier Pond and Fruitgrowers Reservoir (sites FRP and FGR in fig. 52) are located near irrigated areas adjacent to the Uncompahgre Project, but are not in 
the irrigated area served by the project. Highline Reservoir (fig. 53) is in the upper Mack Wash Basin, and most of the inflow into the reservoir is irrigation water from the Government Highline Canal. Apparently, selenium accumulates in fish and birds in the study area to levels that indicate human consumption of such items need to be limited if eaten on a daily basis. It is unlikely that residents eat fish and game birds on a daily basis; therefore, selenium toxicity probably is not a major issue regarding human health in the Uncompahgre Project area and in the Grand Valley.

Table 38. Selenium concentrations in fish-fillet and birdbreast samples from the Uncompahgre Project area and the Grand Valley, and the quantity of each sample that could be consumed without exceeding the maximum recommended daily quantity for an adult human

[Selenium concentrations in micrograms per gram wet weight; recommended daily consumption limit for selenium is 200 micrograms (National Academy of Sciences, 1980); daily consumption limit is the quantity of the food item, in ounces per day, that would need to be consumed to equal the daily consumption limit of 200 micrograms]

\begin{tabular}{|c|c|c|c|}
\hline $\begin{array}{c}\text { Type } \\
\text { of } \\
\text { sample }\end{array}$ & $\begin{array}{l}\text { Sampling } \\
\text { location }\end{array}$ & $\begin{array}{l}\text { Selenlum } \\
\text { concentration }\end{array}$ & $\begin{array}{c}\text { Daily } \\
\text { consumption } \\
\text { Ilmit }\end{array}$ \\
\hline $\begin{array}{l}\text { Yellow perch } \\
\text { fillet }\end{array}$ & $\begin{array}{l}\text { Crawford } \\
\text { Reservoir }\end{array}$ & 3.1 & 2.3 \\
\hline $\begin{array}{l}\text { Brown trout } \\
\text { fillet }\end{array}$ & $\begin{array}{l}\text { Cummings } \\
\text { Gulch }\end{array}$ & 2.6 & 2.7 \\
\hline $\begin{array}{l}\text { Channel catfish } \\
\text { fillet }\end{array}$ & $\begin{array}{l}\text { Highline } \\
\text { Reservoir }\end{array}$ & 1.9 & 3.7 \\
\hline $\begin{array}{l}\text { Largemouth } \\
\text { bass fillet }\end{array}$ & $\begin{array}{l}\text { Highline } \\
\text { Reservoir }\end{array}$ & 2.2 & 3.2 \\
\hline Mallard breast & Ferrier Pond & 7.4 & .95 \\
\hline Mallard breast & Ferrier Pond & 5.6 & 1.3 \\
\hline Mallard breast & Ferrier Pond & 10.3 & .68 \\
\hline Coot breast & $\begin{array}{l}\text { Fruitgrowers } \\
\text { Reservoir }\end{array}$ & 1.9 & 3.7 \\
\hline Coot breast & $\begin{array}{l}\text { Fruitgrowers } \\
\text { Reservoir }\end{array}$ & 2.2 & 3.2 \\
\hline
\end{tabular}

\section{SUMMARY}

The U.S. Department of the Interior began a program in 1985 to determine the effects of irrigation drainage on water quality and on fish and wildlife resources in the Western United States. This report describes results of a study done in 1991-93 of irrigation drainage associated with the Uncompahgre Project area and the Grand Valley in west-central Colorado. The focus of the report is on the sources, distribution, movement, and fate of selenium in the hydrologic and biologic system. The information collected for the study is for use in identifying potentially serious water-quality problems related to irrigation drainage and to provide scientific understanding needed to develop alternatives to mitigate or resolve the problems.

In irrigated areas of the Uncompahgre Project, residual soils and alluvium primarily derived from Mancos Shale contained the highest concentrations of total and water-extractable selenium. Geometric mean selenium concentrations for soils derived from the Mancos Shale were 10 to 13 times greater than the geometric mean for soils in the Western United States. Selenium concentrations in 128 alfalfa samples ranged from less than 0.3 to $9.5 \mu \mathrm{g} / \mathrm{g}$ dry weight, and only 5 samples had concentrations that exceeded the recommended dietary limit of $4 \mu \mathrm{g} / \mathrm{g}$ for consumption by livestock. These results indicate that irrigation practices might be mobilizing and redistributing selenium in the Uncompahgre Project.

In the Uncompahgre Project area and in the Grand Valley, distribution and concentrations of dissolved selenium in ground water differ according to the hydrogeologic setting. The highest concentrations of dissolved selenium (maximum 1,300 $\mu \mathrm{g} / \mathrm{L}$ ) were in water from wells completed in alluvium overlying Mancos Shale. The lowest concentrations of dissolved selenium were in water from wells completed in terrace deposits on the western side of the Uncompahgre Valley and in water from wells completed in Mancos Shale residuum. Dissolvedselenium concentrations in ground water of the study area generally were higher during summer when irrigation water was applied than during winter. Selenium concentrations decreased in winter when irrigation ceased and reducing geochemical conditions tended to remove selenium from solution. Dissolved-selenium concentrations were low where the platinum-electrode potential was low and the hydrogeologic system was more reducing. Selenium in the Uncompahgre Project and in the Grand Valley could be mobilized by oxidation of reduced selenium, desorption of selenium from aquifer sediments, ion exchange, and by dissolution of selenium. Dissolved solids and dissolved selenium are positively correlated in water from wells completed in alluvium, possibly because of desorption and ion-exchange processes, but dissolved solids and selenium are negatively correlated in water from wells completed in shale 
residuum. The application of irrigation water and perhaps nitrate fertilizers on alluvium and shale residuum in the study area mobilizes selenium by desorption, ion exchange, or oxidation into more mobile chemical forms where the selenium is transported by ground water to streams and irrigation drains tributary to the Gunnison, Uncompahgre, and Colorado Rivers.

Median selenium concentrations in the Gunnison and Colorado Rivers upstream from the Uncompahgre Project area and the Grand Valley were less than or equal to $1 \mu \mathrm{g} / \mathrm{L}$. Downstream from the irrigated areas, the median selenium concentrations (1975-92) were $7 \mu \mathrm{g} / \mathrm{L}$ for the Gunnison River at Whitewater (about $10 \mathrm{mi}$ from the confluence with the Colorado River) and $5 \mu \mathrm{g} / \mathrm{L}$ for the Colorado River near the Colorado-Utah State line. About 64 percent of the samples from the Gunnison River and almost 50 percent of the samples from the Colorado River exceeded the U.S. Environmental Protection Agency's aquatic-life criterion of $5 \mu \mathrm{g} / \mathrm{L}$. There apparently was a significant decreasing trend in selenium concentrations in the Colorado River near the Colorado-Utah State line during 1975-92. The Uncompahgre Project and the Grand Valley may account for as much as 75 percent of the selenium load in the Colorado River near the State line.

The highest selenium concentrations in surfacewater samples were collected in areas primarily irrigated on Mancos Shale. The selenium concentrations exceeded $5 \mu \mathrm{g} / \mathrm{L}$ in almost all surface-water samples collected during the nonirrigation season (November through March) from the eastern side of the Uncompahgre Project and from the Grand Valley. For nonirrigation-season samples, the median selenium concentration was $105 \mu \mathrm{g} / \mathrm{L}$ for the eastern side of the Uncompahgre Project and $50 \mu \mathrm{g} / \mathrm{L}$ for the Grand Valley. The largest selenium concentrations in surface water in the Uncompahgre Project were in the Loutsenhizer Arroyo Basin and in the area between the Garnet Canal and Peach Valley Arroyo. In the Grand Valley, the highest selenium concentrations were in parts of the Salt Creek, Reed Wash, and Leach Creek Basins. The maximum selenium concentrations in surface-water samples collected in 1991-93 were $600 \mu \mathrm{g} / \mathrm{L}$ in the Uncompahgre Project area and $380 \mu \mathrm{g} / \mathrm{L}$ in the Grand Valley. Selenium concentrations generally were lower on the western side of the Uncompahgre Project and in the Redlands and Orchard Mesa areas in the Grand Valley because these areas primarily are irrigated on soils derived from terrace deposits that contain less shale detritus than soils in Mancos Shale areas.

The eastern side of the Uncompahgre Project is the primary source of selenium loading from the Uncompahgre Project. Loutsenhizer Arroyo and Cedar Creek, on the eastern side of the project, and Dry Creek, on the western side of the project, discharged the largest selenium loads to the Uncompahgre River. The highest mean selenium load from a tributary stream was $14.0 \mathrm{lb} / \mathrm{d}$ in Loutsenhizer Arroyo. Much of the selenium load measured during 1991-92 in west-side tributaries, such as Dry Creek and Roubideau Creek, probably was transported into these basins in the irrigation water and winter water by the Ironstone Canal. The Uncompahgre Project also contributes substantial selenium loads to the Gunnison River between Peach Valley Arroyo and the Uncompahgre River.

The largest selenium loads from the Grand Valley were in Salt Creek, Reed Wash, Big Salt Wash, and Leach Creek, which drain large areas of irrigated land in the western one-half of the valley. The highest selenium load from the Grand Valley during 1991-92 was $12.8 \mathrm{lb} / \mathrm{d}$ in Reed Wash. Generally, selenium loads were less than $0.2 \mathrm{lb} / \mathrm{d}$ in washes and ditches in the Redlands area, the area east of Grand Junction, and on Orchard Mesa. In some Grand Valley streams, such as Reed Wash, selenium loads were considerably larger during the irrigation season than the nonirrigation season.

Irrigation drainage from the Uncompahgre Project and from the Grand Valley is a major source of dissolved solids in the Upper Colorado River Basin. Median dissolved-solids concentrations for nonirrigation-season samples were $1,160 \mathrm{mg} / \mathrm{L}$ for the western side of the Uncompahgre Project, $4,110 \mathrm{mg} / \mathrm{L}$ for the eastern side of the Uncompahgre Project, and $3,600 \mathrm{mg} / \mathrm{L}$ for the Grand Valley. There are positive correlations between selenium and dissolved-solids loads for tributary streams in the study area. For 15 basins in the Grand Valley, the correlation coefficient was 0.91 between selenium yield and dissolvedsolids yield. Salinity-control projects that were designed to decrease dissolved-solids loads from irrigated areas also could have decreased selenium loading.

Much of the gain in dissolved solids in irrigation-drain water in the study area was from gains of calcium, sodium, magnesium, and sulfate 
ions. An analysis of chloride and selenium data indicated that selenium concentrations in irrigation drainage in the Grand Valley were 5 to 100 times greater than the selenium concentrations predicted from evaporative concentration of the irrigation source water. Based on ratios of sulfate to selenium, selenium was most readily mobilized in the Loutsenhizer Arroyo Basin; in the area between the Garnet Canal and Peach Valley Arroyo; and in the Salt Creek, Reed Wash, Leach Creek, and Indian Wash Basins. Low selenium concentrations and higher sulfate to selenium ratios for pond-water samples might be indicative of removal of selenium by chemical and biological processes in ponds. Some of the highest selenium concentrations in surface water were associated with high nitrite-plus-nitrate concentrations, and there are significant correlations of selenium to nitrite-plus-nitrate concentrations in surface-water samples from the study area.

Many concentrations of other potentially toxic trace constituents in surface water were equal to or less than analytical reporting limits and did not exceed aquatic-life criteria. The highest uranium concentrations in surface water in each area were in samples from reference sites; the maximum uranium concentration was $83 \mu \mathrm{g} / \mathrm{L}$ for Big Salt Wash upstream from the Government Highline Canal in the Grand Valley. A one-time sampling for 26 organophosphate and carbamate insecticides in the Grand Valley indicated that concentrations of most compounds were at or less than reporting limits.

Selenium concentrations in bottom-sediment samples from eight streams and four ponds exceeded the base-line concentration of $1.4 \mu \mathrm{g} / \mathrm{g}$ for soils in the Western United States, and most of the concentrations exceeded the level of concern of $4 \mu \mathrm{g} / \mathrm{g}$ for fish and wildlife. The maximum selenium concentration in bottom-sediment samples was $47 \mu \mathrm{g} / \mathrm{g}$. Ponds and wetlands probably are sinks for selenium in the study area. Soluble and adsorbed selenium accounted for less than 10 percent of the total selenium in seven of eight bottom-sediment samples from streams.

Biota collected from the eastern side of the Uncompahgre Project generally had higher selenium concentrations than biota from the western side. Selenium concentrations in some aquatic-plant and aquatic-invertebrate samples exceeded $3 \mu \mathrm{g} / \mathrm{g}$ dry weight, a dietary guideline for fish and wildlife. Most whole-body fish samples from the Uncompahgre Project and adjacent areas had selenium concentrations that exceeded the 1984 NCBP 85 th percentile $(0.73 \mu \mathrm{g} / \mathrm{g}$ wet weight $)$. The NCBP 85th percentile is used for comparative purposes and does not necessarily indicate a hazard to fish. A trout sample from Crawford Reservoir had a selenium concentration of $18 \mu \mathrm{g} / \mathrm{g}$ dry weight.

Selenium concentrations in some aquatic plants and aquatic invertebrates from the Grand Valley exceeded the dietary guideline ( $3 \mu \mathrm{g} / \mathrm{g}$ dry weight) for protection of fish and wildlife. All selenium concentrations in whole-body fish samples collected from tributary streams and washes in the Grand Valley exceeded the 1984 NCBP 85th percentile. Egg and liver samples from catfish from Highline Reservoir and Salt Creek had selenium concentrations that exceeded levels of concern for reproductive success of freshwater anadromous fish. There was a general trend of increasing selenium concentrations in roundtail chubs and speckled dace in a downstream (east to west) direction for tributary streams in the Grand Valley.

The mean selenium concentration of $7.1 \mu \mathrm{g} / \mathrm{g}$ dry weight for fish samples collected in 1992 from the Gunnison River Basin (one site was on the North Fork) was significantly higher (probability 0.05 ) than the mean concentrations for fish from the Uncompahgre River ( $5.1 \mu \mathrm{g} / \mathrm{g}$ dry weight) and from the Colorado River $(4.6 \mu \mathrm{g} / \mathrm{g}$ dry weight). Selenium concentrations in about 71 percent of the fish samples from the Gunnison and North Fork of the Gunnison Rivers, about 64 percent of the fish samples from the Uncompahgre River, and about 55 percent of the fish samples from the Colorado River exceeded a guideline of $4 \mu \mathrm{g} / \mathrm{g}$ dry weight for selenium in wholebody fish. Speckled dace contained significantly (probability 0.05 ) higher selenium concentrations than roundtail chubs, mottled sculpin, or suckers. Mean selenium concentrations in suckers from the Gunnison River at Delta and Whitewater were significantly higher than the mean concentrations in suckers from the Gunnison River at Austin and the North Fork near Lazear. Suckers from the Colorado River collected upstream from the Grand Valley had significantly (probability 0.05 ) less selenium than suckers collected in and downstream from the Grand Valley.

Using selenate and selenite data for five streams in the Grand Valley to calculate risk factors for endangered fish, selenate concentrations would pose a theoretical moderate risk to the swim-up life stage ( 0 to 98 days old) of endangered Colorado squawfish 
and to all three of the tested life stages of endangered razorback suckers. Because selenite concentrations were much smaller than selenate concentrations, selenite would be a lower risk to the endangered fish than selenate.

Except for selenium, copper concentrations in whole-body fish from the study area most often exceeded the 1984 NCBP 85th percentile. Some copper concentrations in aquatic plants and invertebrates from the Uncompahgre Project area and in fish from the Gunnison River were indicative of copper contamination. Relatively few concentrations of arsenic, cadmium, lead, mercury, and zinc in whole-body fish exceeded the 1984 NCBP 85th-percentile concentrations. About 16 percent of the fish from the Colorado River exceeded the 1984 NCBP 85th percentile for mercury. Risk assessments for Colorado squawfish and razorback suckers to boron, vanadium, and zinc for five tributary streams in the Grand Valley most often were in the moderate risk category. Zinc concentrations in Adobe Creek, Leach Creek, and Indian Wash were in the high-risk category for the swim-up stage of Colorado squawfish.

An anomalously high toxaphene concentration of $0.82 \mu \mathrm{g} / \mathrm{g}$ wet weight was reported for a flannelmouth sucker from Dry Creek in the Uncompahgre Project. The highest concentrations of several polycyclic aromatic hydrocarbons (PAH) were in a white sucker collected from the North Fork of the Gunnison River near Paonia.

Selenium concentrations in food items of migratory birds in the Uncompahgre Project area greatly exceeded a recommended guideline of $3 \mu \mathrm{g} / \mathrm{g}$ dry weight for protection of consumer wildlife. Fathead minnows from ponds had very high concentrations, including $59 \mu \mathrm{g} / \mathrm{g}$ dry weight in a sample from Brozina Pond (located in the Uncompahgre Project) and 72 and $110 \mu \mathrm{g} / \mathrm{g}$ dry weight in two samples from St. George Pond (located outside the project north of the Gunnison River). Selenium concentrations in bird eggs and livers in the Uncompahgre Project area exceeded normal concentrations, and some samples had concentrations in the high-risk category for adverse biological effects. The geometric mean selenium concentration of $41.9 \mu \mathrm{g} / \mathrm{g}$ dry weight for five avocet eggs from Brozina Pond was similar to selenium concentrations associated with a 5-percent incidence of teratogenic effects. The geometric mean selenium concentration of $6.7 \mu \mathrm{g} / \mathrm{g}$ dry weight for bird eggs from the Grand Valley was about one-half the mean concentration for eggs from the Uncompahgre Project area. The selenium concentrations in bird eggs and livers from the Grand Valley were in the range of uncertainty regarding biological risk. Concentrations of other trace constituents in biota from wetlands generally were less than adverse-effect levels or were in normal concentration ranges.

Bird eggs were collected in 1992 and incubated in a laboratory, and of the 65 eggs incubated, only one had any visual deformities. Of the 25 yellow-headed blackbird nests monitored at Ferrier Pond (east of the Uncompahgre Project) in 1992, one prefledgling bird was found dead, and that bird had $43 \mu \mathrm{g} / \mathrm{g}$ dry weight of selenium. Two dead prefledgling mallards (selenium concentrations of 26 and $27 \mu \mathrm{g} / \mathrm{g}$ dry weight) found at Markley Pond on the eastern side of the Uncompahgre Project did not have abnormalities or deformities. Also from Markley Pond, two dead coot hatchlings had a selenium concentration of $19 \mu \mathrm{g} / \mathrm{g}$ dry weight (combined sample), and two coot eggs incubated at the laboratory that had dead embryos when opened (never hatched) had a selenium concentration of $39 \mu \mathrm{g} / \mathrm{g}$ dry weight (combined sample).

Chronic toxicity water tests on Ceriodaphnia and fathead minnow lavae using irrigation drainage from five Grand Valley streams indicated no significant difference between control solutions and test solutions, except for chronic toxicity to fathead minnows for the water sample from Leach Creek. A growth and survival test using Hyallela on bottomsediment samples indicated no significant difference between test sediment and control sediment.

The highest bioaccumulation factors of selenium in the study area were from water to biota. For samples collected at wetlands in the Uncompahgre Project irrigated area, the bioaccumulation factor between water and fish was about 10,600. The highest bioaccumulation factor was about 20,900 from water to bird livers collected in the Uncompahgre Project. Bioaccumulation of selenium between bottom sediment and biota and in biota trophic levels were much smaller than between water and biota.

Selenium accumulates in fish and birds in the study area to levels that would limit human consumption if eaten on a daily basis. Because it is unlikely that residents eat fish and birds taken in the study area on a daily basis, selenium probably is not a human health concern in the study area. 


\section{REFERENCES CITED}

Anderson, M.S., Lakin, H.W., Beeson, K.C., Smith, F.F., and Thacker, Edward, 1961, Selenium in agriculture: U.S. Department of Agriculture, Handbook 200, 65 p.

Archer, D.L., Kaeding, L.R., Burdick, B.D., and McAda, C.W., 1985, A study of the endangered fishes of the upper Colorado River: U.S. Fish and Wildlife Service Final Report 4-16-0006-82-959.

Armstrong, F.A.J., 1979, Effects of mercury compounds on fish, in Nriagu, J.O., ed., The biogeochemistry of mercury in the environment: New York, Elsevier/North-Holland Biomedical Press, p. 657-670.

Balistrieri, L.S., and Chao, T.T., 1987, Selenium adsorption by goethite: Soil Science Society of America Journal, v. 51 , no. 5 , p. $1145-1151$.

Ball, J.W., and Nordstrom, D.K., 1991, User's manual for WATEQ4F, with revised thermodynamic data base and test cases for calculating speciation of major, trace, and redox elements in natural waters: U.S. Geological Survey Open-File Report 91-183, 193 p.

Barcelona, M.J., Helfrich, J.A., Garske, E.E., and Gibb, J.P., 1984, A laboratory evaluation of ground-water sampling mechanisms: Ground-Water Monitoring Review, spring 1984, p. 32-41.

Bar-Yosef, B., and Meek, D., 1987, Selenium sorption by kaolinite and montmorillonite: Soil Science, v. 144, no. 1, p. 11-19.

Beath, O.A., 1962, Selenium in naturally occurring underground water: Science Newsletter, v. 81, p. 254.

Beath, O.A., Eppson, H.F., and Gilbert, C.S., 1937, Selenium distribution in and seasonal variation of type vegetation occurring on seleniferous soils: Journal of the American Pharmaceutical Association, v. 26 , p. $394-405$.

Behnke, R.J., and Benson, D.E., 1983, Endangered and threatened fish species in the upper Colorado River as related to Bureau of Reclamation projects: Salt Lake City, Bureau of Reclamation, $36 \mathrm{p}$.

Berner, R.A., 1981, A new geochemical classification of sedimentary environments: Journal of Sedimentary Petrology, v. 51, no. 2, p. 359-365.

Binder, C.W., Bargsten, G., Mancuso, B.F., Evans, R.G., Walker, W.R., and Skogerbee, G.V., 1978, Grand Valley salinity control demonstration project-Basic field data: Fort Collins, Colorado State University, $194 \mathrm{p}$.

Brown, A.F., 1979, The incubation book: The World Pheasant Association, 246 p.
Brooks, Tom, and Ackerman, D.J., 1985, Reconnaissance of ground-water resources in the lower Gunnison River basin, southwestern Colorado: U.S. Geological Survey Water-Resources Investigations Report 84-4185, 30 p.

Bureau of Reclamation, 1977, Hydrogeologic studyLower Gunnison Unit: Salt Lake City, five sections plus maps.

1978, Stage One development, Grand Valley Unit, definite plan report-Appendix B, hydrosalinity, land resource, economics: Salt Lake City, five numbered sections plus attachments.

1982, Lower Gunnison Basin Unit, Feasibility report-Appendix B, hydrosalinity: Salt Lake City, $86 \mathrm{p}$.

1983, Grand Valley salt pickup calculations, Colorado River Basin Salinity Control Project: Grand Junction, Colo., three sections plus appendix. 1984, Lower Gunnison Basin Unit, feasibility report/final environmental statement: Salt Lake City, $204 \mathrm{p}$.

1985, Grand Valley Unit, Stage Two development, final environmental impact statement: Bureau of Reclamation Report INT FES86-10, 217 p.

1986a, Cobble aquifer investigation: Grand Junction, Colo., six numbered sections plus appendices.

1986b, Colorado River Basin Salinity Control

Project, Grand Valley Unit-Stage Two development: Grand Junction, Colo., eight chapters.

1987, Lower Gunnison Basin Unit-Winter Water: Salt Lake City, Colorado River Water Quality Improvement Program Preconstruction Report, $57 \mathrm{p}$.

Butler, D.L., Krueger R.P., Osmundson, B.C., Thompson, A.L., and McCall, S.K., 1991, Reconnaissance investigation of water quality, bottom sediment, and biota associated with irrigation drainage in the Gunnison and Uncompahgre River Basins and at Sweitzer Lake, west-central Colorado, 1988-89: U.S. Geological Survey Water-Resources Investigations Report 91-4103, 99 p.

Butler, D.L., Wright, W.G., Hahn, D.A., Krueger, R.P., and Osmundson, B.C., 1994, Physical, chemical, and biological data for the detailed study of irrigation drainage in the Uncompahgre Project area and in the Grand Valley, west-central Colorado, 1991-92: U.S. Geological Survey Open-File Report 94-110, 146 p.

Byers, H.G., 1935, Selenium occurrence in certain soils in the United States with a discussion of related topics: U.S. Department of Agriculture Technical Bulletin 482, p. 1-47. 
Cairns, J., Dickson, K.L., and Maki, A.W., 1978, Estimating the hazard of chemical substances to aquatic life: American Society for Testing and Materials Special Technical Publication 657, $278 \mathrm{p}$.

Cannon, H.L., 1954, Methods of botanical prospecting for uranium deposits on the Colorado Plateau: U.S. Geological Survey Trace-Elements Investigations Report TEI-422, 103 p.

Cashion, W.B., comp., 1973, Geologic and structure map of the Grand Junction quadrangle, Colorado and Utah: U.S. Geological Survey Miscellaneous Investigations Series Map I-736, scale 1: 250,000 (reprinted 1979).

Cline, A.J., Spears, C., Mehaffey, F., Kubin, E., Franklin, R., Pachek, C., Knobel, E.W., Decker, R., and McMahen, D., 1967, Soil survey of DeltaMontrose area, Colorado: U.S. Department of Agriculture Series, 73 p.

Cole, R.D., and Young, R.G., 1991, Facies characterization and architecture of a muddy shelf-sandstone complex-Mancos B interval of Upper Cretaceous Mancos Shale, northwest Colorado-northeast Utah, in Miall, A.D., and Tyler, Noel, eds., The threedimensional facies architecture of terrigenous clastic sediments and its implications for hydrocarbon discovery and recovery: Tulsa, Okla., SEPM Society for Sedimentary Geology, Concepts in Sedimentology and Paleontology, v. 3, p. 277-287.

Coleman, R.G., and Delevaux, Maryse, 1957, Occurrence of selenium in sulfides from some sedimentary rocks of the Western United States: Economic Geology, v. 52 , no. 5 , p. $499-527$.

Colorado Department of Health, 1989, The basic standards and methodologies for surface water, section 3.1.0: Denver, Colo., Water Quality Control Commission, $111 \mathrm{p}$.

Combs, G.F., Jr., and Combs, S.B., 1986, The role of selenium in nutrition: New York, Academic Press, $532 \mathrm{p}$.

Craig, T.W., 1971, Ground water of the Uncompahgre Valley, Montrose County, Colorado: Rolla, masters thesis, University of Missouri, $115 \mathrm{p}$.

Crock, J.G., and Lichte, F.E., 1982, An improved method for the determination of trace levels of arsenic and antimony in geologic materials by automated hydride generation-atomic absorption spectroscopy: Analytica Chimica Acta, v. 144, p. 223-233.

Crock, J.G., Lichte, F.E., and Briggs, P.E., 1983, Determination of elements in National Bureau of Standards geologic reference materials SRM 278 obsidian and SRM 688 basalt by inductively coupled argon plasmaatomic emission spectrometry: Geostandards Newsletter, v. 7, p. 335-340.
Crock, J.G., Stewart, K.C., and Severson, R.C., 1994, Listing of geochemical data and assessment of variability for alfalfa and soils of the Uncompahgre Project area, Colorado: U.S. Geological Survey Open-File Report 94-580, 83 p.

Cumbie, P.M., and Van Horn, S.L., 1978, Selenium accumulation associated with fish mortality and reproductive failure: Annual Conference of the Southeast Association of Fish and Wildlife Agencies Proceedings, v. 32, p. 612-624.

Deason, J.P., 1986, Irrigation-induced contamination problems, in Summers, J.B., and Anderson, S.S., eds., Toxic substances in agricultural water supply and drainage-Defining the problems: U.S.Committee on Irrigation and Drainage, Regional Meeting, Washington, D.C., 1986, Proceedings, p. 201-210.

Deverel, S.J., Gilliom, R.J., Fujii, Roger, Izbicki, J.A., and Fields, J.C., 1984, Areal distribution of selenium and other inorganic constituents in shallow ground water of the San Luis Drain service area, San Joaquin Valley, California-A preliminary study: U.S. Geological Survey Water-Resources Investigations Report 84-4319, 67 p.

Deverel, S.J., and Millard, S.P., 1988, Distribution and mobility of selenium and other trace elements in shallow groundwater of the western San Joaquin Valley, California: Environmental Science and Technology, v. 22, no. 6, p. 697-702.

Dixon, D.G., and Sprague, J.B., 1981, Copper bioaccumulation and hepatoprotein synthesis during acclimation to copper by juvenile rainbow trout: Aquatic Toxicology, v. 1 , p. $69-81$.

Dubrovsky, N.M., Neil, J.M., Fujii, Roger, Oremland, R.S., and Hollibaugh, J.T., 1990, Influence of redox potential on selenium distribution in ground water, Mendota, western San Joaquin Valley, California: U.S. Geological Survey Open-File Report 90-138, $24 \mathrm{p}$.

Duke, H.R., Kruse, E.G., Olsen, S.R., Champion, D.F., and Kincaid, D.C., 1976, Irrigation return flow water quality as affected by irrigation water management in the Grand Valley of Colorado: Fort Collins, Colo., U.S. Department of Agriculture, $123 \mathrm{p}$.

Eisler, Ronald, 1985, Cadmium hazards to fish, wildlife, and invertebrates-A synoptic review: U.S. Fish and Wildlife Service Biological Report 85 (1.2), 46 p. 1986, Chromium hazards to fish, wildlife, and invertebrates-A synoptic review: U.S. Fish and Wildlife Service Biological Report 85 (1.6), 60 p. 1987a, Mercury hazards to fish, wildlife, and invertebrates-A synoptic review: U.S. Fish and Wildlife Service Biological Report 85 (1.10), 90 p. 
1987b, Polycyclic aromatic hydrocarbon hazards to fish, wildlife, and invertebrates-A synoptic review: U.S. Fish and Wildlife Service Biological Report 85 (1.11), $81 \mathrm{p}$.

1988, Arsenic hazards to fish, wildlife, and invertebrates-A synoptic review: U.S. Fish and Wildlife Service Biological Report 85 (1.12), 92 p.

Eisler, Ronald, and Jacknow, J., 1985, Toxaphene hazards to fish, wildlife, and invertebrates-A synoptic review: U.S. Fish and Wildlife Service Biological Report 85 (1.4), $26 \mathrm{p}$.

Electric Power Research Institute, 1980, Adsorption/ coprecipitation of trace elements from water with iron oxyhydroxide: Palo Alto, Calif.

Elrashidi, M.A., Adriano, D.C., and Lindsey, W.L., 1989, Solubility, speciation, and transformations of selenium in soils, in Jacobs, L.W., ed., Selenium in agriculture and the environment: Soil Science Society of America Special Publication 23, p. 51-63.

Elrashidi, M.A., Adriano, D.C., Workman, S.M., and Lindsey, W.L., 1987, Chemical equilibria of selenium in soils-A theoretical development: Soil Science, v. 144 , no. 2 , p. 141-152.

Epstein, S., and Mayeda, T., 1953, Variations of the O-18 content of waters from natural sources: Geochimica et Cosmochimica Acta, v. 4, p. 213-224.

Erdman, J.A., Ebens, R.J., and Case, A.A., 1978, Molybdenosis-A potential problem in ruminants grazing on coal mine spoils: Journal of Range Management, v. 31, p. 34-36.

Finley, M.T., Stickel, W.H., and Christensen, R.E., 1979 , Mercury residues in tissues of dead and surviving birds fed methyl mercury: Environmental Contaminants and Toxicology Bulletin, v. 21, p. 105-110.

Fio, J.L., and Fujii, Roger, 1990, Selenium speciation methods and application to soil saturation extracts from San Joaquin Valley, California: Soil Science Society of America Journal, v. 54, no. 2, p. 363-369.

Fireman, M., Gardner, R., and Reeve, R.C., 1951, Studies of saline and alkali soils of the Grand Junction area, Colorado: Colorado Agricultural Experiment Station, Research Summary 8, $51 \mathrm{p}$.

Fisher, S.E., Jr., Munshower, F.F., and Parady, Fred, 1987, Selenium, in Williams, R.D., and Schuman, G.E., eds., Reclaiming mine soils and overburden-Analytical parameters and procedures: Ankeny, Iowa, Soil Conservation Society of America, p. 109-133.

Fishman, M.J., and Friedman, L.C., eds., 1989, Methods for determination of inorganic substances in water and fluvial sediments (3rd ed.): U.S. Geological Survey Techniques of Water-Resources Investigations, book 5 , chap. A1, 545 p.
Fishman, N.S., and Reynolds, R.L, 1986, Diagenesis of the Morrison Formation, Smith Lake uranium district, McKinley County, New Mexico, in Mumpton, F.A., ed., Studies in diagenesis: U.S. Geological Survey Bulletin 1578, p. 249-263.

Fishman, N.S., Reynolds, R.L., and Robertson, J.F., 1985, Uranium mineralization in the Smith Lake district of the Grants uranium region, New Mexico: Economic Geology and the Bulletin of the Society of Economic Geologists, v. 80, no. 5, p. 1348-1364.

Follett, R.H., Kendall, P.A., Doherty, T.J., Williamson, C.E., Golus, H.M., and Stack, M.W., 1990, Selenium levels found in soil, water, vegetable and field crop samples in western Colorado: Colorado State University Technical Bulletin LTB90-2, 12 p.

Frankenberger, W.T., Jr., and Karlson, U., 1992, Dissipation of soil selenium by microbial volatilization, in Adriano, D.C., ed., Biogeochemistry of trace metals: Boca Raton, Fla., Lewis Publishers, p. 365-381.

Fry, B., Gest, H., and Hayes, J.M., $1988,{ }^{34} \mathrm{~S} /{ }^{32} \mathrm{~S}$ fractionation in sulfur cycles catalyzed by anaerobic bacteria: Applied Environmental Microbiology, v.54, no. 1, p. 250-256.

Fujii, Roger, and Deverel, S.J., 1989, Mobility and distribution of selenium and salinity in groundwater and soil of drained agricultural fields, western San Joaquin Valley of California, in Jacobs, L.W., ed., Selenium in agriculture and the environment: Soil Science Society of America Special Publication 23, p. 195-212.

Fujii, Roger, Deverel, S.J., and Hatfield, D.B., 1988, Distribution of selenium in soils of agricultural fields, western San Joaquin Valley, California: Soil Science Society of America Journal, v. 52, no. 5, p. 1274-1283.

Garrels, R.M., and Christ, C.L., 1965, Solutions, minerals, and equilibria: New York, Harper and Row, 450 p.

Gat, J.R., 1981, Isotopic fractionation, in Gat, J.R., and Gonfiantini, R., Stable isotope hydrology: Vienna, International Atomic Energy Agency, p. 21-33.

Geering, H.R., Cary, E.E., Jones, L.H.P., and Allaway, W.H., 1968, Solubility and redox criteria for the possible forms of selenium in soils: Soil Science Society of America Proceedings, v. 32, p. $35-40$.

Gill, J.R., and Hail, W.J., Jr., 1975, Stratigraphic sections across Upper Cretaceous Mancos Shale-Mesaverde Group boundary, eastern Utah and western Colorado: U.S. Geological Survey Oil and Gas Investigations Chart OC-68, 1 sheet [scale unknown].

Gilliom, R.J., and others, 1989, Preliminary assessment of sources, distribution, and mobility of selenium in the San Joaquin Valley, California: U.S. Geological Survey Water-Resources Investigations Report 88-4186, 129 p. 
Hamilton, S.J., 1993, Yankton research station studies effects of environmental contaminants on endangered fish: Endangered Species Technical Bulletin, v. 18, no. 2, p. 19.

Harms, T.F., Stewart, K.C., Briggs, P.H., Hageman, P.L., and Papp, C.S., 1990, Chemical results for bottom material for Department of the Interior irrigation drainage task group studies 1988-89: U.S. Geological Survey Open-File Report 90-50, 47 p.

Harrison, H.H., 1979, A field guide to Western birds' nests in the United States west of the Mississippi River: Boston, Houghton Mifflin, 279 p.

Hayes, K.F., Roe, A.L., Brown, G.F., Jr., Hodgson, K.O., Leckie, J.O., and Parks, G.A., 1987, In situ X-ray absorption study of surface complexes-Selenium oxyanions on alpha-FeOOH: Science, v. 238, p. 783-786.

Hedlund, J.D., 1994, Water and salt budgets: Portland, Oreg., U.S. Department of Agriculture, Soil Conservation Service, West National Technical Center, 60 p.

Heinz, G.H., 1979, Methylmercury-Reproductive and behavioral effects on three generations of mallard ducks: Journal of Wildlife Management, v. 43, no. 2, p. 394-401.

Howard, J.H., III, 1977, Geochemistry of seleniumformation of ferroselite and selenium behavior in the vicinity of oxidizing sulfide and uranium deposits: Geochimica et Cosmochimica Acta, v. 41, p. $1665-1678$.

Izbicki, J.A., 1989, Chemical quality of agricultural drainage water tributary to Kesterson Reservoir, Fresno and Merced Counties, California, January and August 1984: U.S. Geological Survey OpenFile Report 87-380, 45 p.

Jackson, L.L., Brown, F.W., and Neil, S.T., 1987, Major and minor elements requiring individual determination, classical whole rock analysis, and rapid rock analysis, chap. G of Baedecker, P.A., ed., Methods for geochemical analysis: U.S. Geological Survey Bulletin 1770, p. G1-G23.

Johnston, E.P., and Baumann, P.C., 1989, Analysis of fish bile with HPLC fluorescence to determine environmental exposure to benzo [a] pyrene: Hydrobiologica, v. $188 / 189$, p. $561-566$.

Jones, B.E., 1987, Quality control manual of the U.S. Geological Survey's National Water Quality Laboratory: U.S. Geological Survey Open-File Report 87-457, $17 \mathrm{p}$.

Kaeding, L.R., and others, 1986, Recent capture of a bonytail (Gila elegans), and observations on this nearly extinct cyprinid from the Colorado River: Copeia, v. 4, p. 1021-1023.

Kemp, A.L.W., and Thode, H.G., 1968, The mechanism of bacterial reduction of sulphate and of sulphite from isotope fractionation studies: Geochimica et Cosmochimica Acta, v. 32, p. 71-91.
Kendall, Carol, and Coplen, T.B., 1985, Multisample conversion of water to hydrogen by zinc for stable isotope determination: Analytical Chemistry, v. 57, no. 7, p. 1437-1440.

Knapton, J.R., 1985, Field guidelines for collection, treatment, and analysis of water samples, Montana District: U.S. Geological Survey Open-File Report 85-409, 86 p.

Korom, S.F., 1992, Natural denitrification in the unsaturated zone: Water Resources Research, v. 28 , no. 6 , p. 1657-1668.

Krueger, R.P., 1988, Heavy metal analysis of seven Colorado squawfish from the Colorado and White Rivers: Grand Junction, Colo., U.S. Fish and Wildlife Service, 4 p.

Kurey, W.J., 1985a, Organochlorine contaminants in fish of the Grand Valley: Grand Junction, Colo., U.S. Fish and Wildlife Service, 11 p. plus appendices.

1985b, Analysis of Colorado squawfish tissues of metal, organochlorine, and petroleum hydrocarbon residues: Grand Junction, Colo., U.S. Fish and Wildlife Service.

Lakin, H.W., 1961, Geochemistry of selenium in relation to agriculture, in Anderson, M.S., Lakin, H.W., Beeson, K.C., Smith, F.F., and Thacker, Edward, Selenium in agriculture: U.S. Department of Agriculture Handbook 200, p. 3-11.

Lemly, A.D., 1985, Toxicology of selenium in a freshwater reservoir-Implications for environmental hazard evaluation and safety: Ecotoxicology and Environmental Safety, v. 10, p. 314-338.

1993, Guidelines for evaluating selenium data from aquatic monitoring and assessment studies: Environmental Monitoring and Assessment, v. 28, p. 83-100.

Lemly, D.A., and Smith, G.J., 1987, Aquatic cycling of selenium-Implications for fish and wildlife:

U.S. Fish and Wildlife Service, Fish and Wildlife Leaflet $12,10 \mathrm{p}$.

Levander, O.A., 1984, The importance of selenium in total parental nutrition: Bulletin of New York Academy of Medicine, v. 60, p. 144-155.

Lipman, J.G., and Waksman, S.A., 1922, The oxidation of selenium by a new group of autotrophic microorganisms: Science, v. 57, no. 1463, p. 60.

Lo, M.T., and Sandi, E., 1980, Selenium-Occurrence in foods and its toxicological significance; a review: Journal of Environmental Pathology and Toxicology, v. 4, p. 193-218.

Lohman, S.W., 1965, Geology and artesian water supply of the Grand Junction area, Colorado: U.S. Geological Survey Professional Paper 451, 149 p. 
Lusby, G.C., 1978, Effects of grazing on runoff and sediment yield from desert rangeland at Badger Wash in western Colorado, 1953-73: U.S. Geological Survey Open-File Report 78-165, 72 p.

Maier, K.J., and Knight, A.W., 1994, Ecotoxicology of selenium in freshwater systems: Reviews of Environmental Contamination and Toxicology, v. 134 , p. $31-48$.

Makita, S.N., and Fujii, R.F., 1992, Quality assurance practices of the U.S. Geological Survey laboratory in Sacramento, California: U.S. Geological Survey Open-File Report 91-522, 24 p.

Marshall, C.H., 1959, Photogeologic map of the Delta quadrangle, Montrose and Delta Counties, Colorado: U.S. Geological Survey Miscellaneous Geologic Investigation Map I-282, scale 1:62,500.

Masscheleyn, P.H., Delaune, R.D., and Patrick, W.H., Jr., 1991, Arsenic and selenium chemistry as affected by sediment redox potential and $\mathrm{pH}$ : Journal of Environmental Quality, v. 20, p. 522-527.

Mayer, F.L., Jr., and Mehrle, P.M., 1977, Toxicological aspects of toxaphene in fish-A summary: Transactions of North American Wildlife Natural Resources Conference, v. 42, p. 365-373.

McDonald, S.J., Wade, T.L., Brooks, J.M., and McDonald, T.J., 1991, Assessing the exposure of fish to a petroleum spill in Galveston Bay, Texas, in Wrobel, L.C., and Brebbia, C.A., eds., Water pollution-Modeling, measuring, and prediction: London, Elsevier Applied Science, p. 707-718.

McKown, D.M., and Mallard, H.T., Jr., 1987, Determination of uranium and thorium by delayed neutron counting, chap. I, of Baedecker, P.A., ed., Methods for geochemical analysis: U.S. Geological Survey Bulletin 1770, p. I1-I12.

Meeks, T.O., 1950, Reconnaissance of ground-water conditions in the Uncompahgre Valley, Colorado: U.S. Soil Conservation Service Regional Bulletin 112, Geologic Series 3, 27 p.

MikkeJson, R.L., Page, A.L., and Bingham, F.T., 1989, Factors affecting selenium accumulation by agricultural crops, in Jacobs, L.W., ed., Selenium in agriculture and the environment: Soil Science Society of America Special Publication 23, p. 65-94.

Miltmore, J.E., and Mason, J.L., 1971, Copper and molybdenum ratio and molybdenum and copper concentrations in ruminant feeds: Canadian Journal of Animal Science, v. 51, p. 193-200.

Moore, J.W., and Ramamoorthy, S., 1984, Heavy metals in natural waters-Applied monitoring and impact assessment: New York, Springer-Verlag, 268 p.
Moxon, A.L., Olson, O.E., Searight, W.V., and Sandals, K.M., 1938, The stratigraphic distribution of selenium in the Cretaceous formations of South Dakota and the selenium content of some associated vegetation: American Journal of Botany, v. 25, no. 10, p. 794-809.

Naftz, D.L., and Rice, J.A., 1989, Geochemical processes controlling selenium in ground water after mining, Powder River basin, Wyoming, U.S.A.: Applied Geochemistry, v. 4, p. 565-575.

National Academy of Sciences, 1980, Recommended dietary allowances (9th ed.): Washington, D.C., National Academy of Sciences Press, 185 p. 1983, Drinking water and health: Washington, D.C., National Academy of Sciences Press, v. 5, $157 \mathrm{p}$.

Natural Resources Council of Canada, 1978, Effects of arsenic in the Canadian environment: Natural Resources Council of Canada Publication NRCC 15391, 349 p.

Nelson, J.W., and Kolbe, L.A., 1912, Soil survey of the Uncompahgre Valley area, Colorado: Washington, D.C., U.S. Department of Agriculture, unnumbered report, $51 \mathrm{p}$.

Ogle, R.S., and Knight, A.W., 1989, Effects of elevated foodborne selenium on growth and reproduction of the fathead minnow (Pimephales promelas): Archives of Environmental Contamination and Toxicology, v. 18, no. 6, p. 795-803.

Ohlendorf, H.M., 1989, Bioaccumulation and effects of selenium in wildlife, in Jacobs, L.W., ed., Selenium in agriculture and the environment: Soil Science Society of America Special Publication 23, p. 133-177. 1993, Marine birds and trace elements in the temperate North Pacific, in Vermeer, K., Briggs, K.T., Morgan, K.H., and Siegal-Causey, D., eds., The status, ecology, and conservation of marine birds of the North Pacific: Ottawa, Canada, Wildlife Service Special Publications, p. 232-240.

Ohlendorf, H.M., Hoffman, D.J., Saiki, M.K., and Aldrich, T.W., 1986, Embryonic mortality and abnormalities of aquatic birds-Apparent impacts of selenium from irrigation drainwater: Science of the Total Environment, v. 52, no. 1/2, p. 49-63.

Ohlendorf, H.M., Kilness, A.W., Simmons, J.C., Stroud, R.K., Hoffman, D.J., and Moore, J.F., 1988, Selenium toxicosis in wild aquatic birds: Journal of Toxicology and Environmental Health, v. 24, p. 67-92.

Ohlendorf, H.M., Skorupa, J.P., Saiki, M.K., and Barnum, D.A., 1993, Food-chain transfer of trace elements to wildlife, in Allen, R.G., and Neale, C.M.U., eds., Proceedings of 1993 National Conference on irrigation and drainage engineering: American Society of Civil Engineers Publication 10017-2398. 
Olson, O.E., Whitehead, E.I., and Moxon, A.L., 1942, Occurrence of soluble selenium in soils and its availability to plants: Soil Science, v. 54, no. 1, p. 47-53.

Oremland, R.S., Hollibaugh, J.T., Maest, A.S., Presser, T.S., Miller, L.G., and Culbertson, C.W., 1989, Selenate reduction to elemental selenium by anaerobic bacteria in sediments and culture--Biogeochemical significance of a novel, sulfate-independent respiration: Applied and Environmental Microbiology, v. 55, no. 9, p. 2333-2343.

Oremland, R.S., Steinberg, N.A., Maest, A.S., Miller, L.G., and Hollibaugh, J.T., 1990, Measurement of in situ rates of selenate removal by dissimilatory bacterial reduction in sediments: Environmental Science and Technology, v. 24, no. 8, p. 1157-1164.

Osmundson, D.B., and Kaeding, L.R., 1989, Studies of Colorado squawfish and razorback sucker use of the "15-mile reach" of the upper Colorado River as part of conservation measures for the Green Mountain and Ruedi Reservoir water sales: Grand Junction, Colo., U.S. Fish and Wildlife Service, 85 p.

Presser, T.S., and Barnes, Ivan, 1985, Dissolved constituents including selenium in waters in the vicinity of Kesterson National Wildlife Refuge and West Grassland, Fresno and Merced Counties, California: U.S. Geological Survey Water-Resources Investigations Report 85-4220, 73 p.

Presser, T.S., Swain, W.C., Tidball, R.R., and Severson, R.C., 1990, Geologic sources, mobilization, and transport of selenium from the California Coast ranges to the western San Joaquin Valley-A reconnaissance study: U.S. Geological Survey Water-Resources Investigations Report 90-4070, 66 p.

Rantz, S.E., and others, 1982, Measurement and computation of streamflow-Volume 1. Measurement of stage and discharge: U.S. Geological Survey Water-Supply Paper 2175, $284 \mathrm{p}$.

Sager, D.R., and Cofield, C.R., 1984, Differential accumulation of selenium among axial muscle, reproductive and liver tissues of four warm water fish species: Water Resources Bulletin, v. 20, no. 3, p. 359-363.

Sanzolone, R.F., and Chao, T.T., 1987, Determination of selenium in thirty-two geochemical reference materials by continuous-flow hydride generation atomic absorption spectrophotometry: Geostandards Newsletter, no. 11, p. 81-85.

Sarathchandra, S.U., and Watkinson, J.H., 1981, Oxidation of elemental selenium to selenite by Bacillus megaterium: Science, v. 211, p. 600-601.

SAS Institute, 1982, SAS user's guide (1982 ed.): Cary, N.C., 921 p.
Schertz, T.L., Alexander, R.B., and Ohe, D.J., 1991, The computer program Estimate Trend (ESTREND), a system for the detection of trends in water-quality data: U.S. Geological Survey Water-Resources Investigations Report 91-4040, 63 p.

Schmitt, C.J., and Brumbaugh, W.G., 1990 , National Contaminant Biomonitoring ProgramConcentrations of arsenic, cadmium, copper, lead, mercury, selenium, and zinc in U.S. freshwater fish, 1976-1984: Archives of Environmental Contamination and Toxicology, v. 19, no. 5, p. 731-747.

Schmitt, C.J., Zajicek, J.L., and Peterman, P.H., 1990, National Contaminant Biomonitoring Program-Residues of organochlorine chemicals in U.S. freshwater fish, 1976-1984: Archives of Environmental Contamination and Toxicology, v. 19 , no. 5 , p. $748-781$.

Schneider, E.J., 1975, Surficial geology of the Grand Junction-Fruita area, Mesa County, Colorado: Fort Collins, Colorado State University, Master's thesis, $141 \mathrm{p}$.

Schultz, R., and Hermanutz, R., 1990, Transfer of toxic concentrations of selenium from parent to progeny in the fathead minnow (Pimephales promelas): Bulletin of Environmental Contamination and Toxicology, v. 45 , no. 4 , p. $568-573$.

Schwochow, S.D., 1978, Mineral resources survey of Mesa County, Colorado-A model study: Colorado Geological Survey Resource Series 2, $100 \mathrm{p}$.

See, R.B., Naftz, D.L., Peterson, D.A., Crock, J.G., Erdman, J.A., Severson, R.C., Ramirez, Pedro, Jr., and Armstrong, J.A., 1992, Detailed study of selenium in soil, representative plants, water, bottom sediment, and biota in the Kendrick Reclamation Project area, Wyoming, 1988-90: U.S. Geological Survey WaterResources Investigations Report 91-4131, 142 p.

Shacklette, H.T., and Boerngen, J.G., 1984, Element concentrations in soils and other surficial materials of the conterminous United States: U.S. Geological Survey Professional Paper 1270, 105 p.

Shamberger, R.J., 1981, Selenium in the environment: Science of the Total Environment, v. 17, p. 59-74.

Sindeeva, N.D., 1964, Mineralogy and types of deposits of selenium and tellurium: New York, Interscience Publishers, $363 \mathrm{p}$.

Singh, M., Singh, N., and Relan, P.S., 1981, Adsorption and desorption of selenite and selenate selenium on different soils: Soil Science, v. 132, p. 134-141.

Skorupa, J.P., and Ohlendorf, H.M., 1991, Contaminants in drainage water and avian risk thresholds, in Dinar, A., and Zilberman, D., eds., The economics and management of water and drainage in agriculture: Boston, Kluwer Academic Publishers, p. 345-368. 
Spears, C.F., and Kleven, E.V., 1978, Soil survey of Mesa County area, Colorado: Washington D.C., Soil Conservation Service, $58 \mathrm{p}$.

Sposito, G., Yang, A., Neal, R.H., and Mackzum, Adrienne, 1991, Selenate reduction in alluvial soil: Soil Science Society of America Journal, v. 55, p. 1597-1602.

Steinberg, N.A., and Oremland, R.S., 1990, Dissimilatory selenate reduction potentials in a diversity of sediment types: Applied and Environmental Microbiology, v. 56 , no. 11 , p. $3550-3557$.

Stephens, D.W., Waddell, Bruce, Peltz, L.A., and Miller, J.B., 1992, Detailed study of selenium and selected elements in water, bottom sediment, and biota associated with irrigation drainage in the middle Green River Basin, Utah, 1988-90: U.S. Geological Survey Water-Resources Investigations Report 92-4084, 164 p.

Steven, T.A., and Hail, W.J., Jr., 1989, Geologic map of the Montrose $30^{\prime}$ x $60^{\prime}$ quadrangle, southwestern Colorado: U.S. Geological Survey Miscellaneous Investigations Series Map I-1939, scale 1:100,000.

Stewart, K.C., Fey, D.L., Dunlap, C.E., and Welsch, E.P., 1990, Water-extractable elements from the Panoche Fan area of the San Joaquin Valley, California: U.S. Geological Survey Open-File Report 90-292, $24 \mathrm{p}$.

Stewart, K.C., Crock, J.G., and Severson, R.C., 1993, Chemical results and variability assessment of selected water-extractable constituents from soils of the Uncompahgre Project area, west-central Colorado: U.S. Geological Survey Open-File Report 93-507, $27 \mathrm{p}$.

Stromberg, J., 1975, A guide to better hatching: Pine River, Minn., Stromberg Publishing Company, $100 \mathrm{p}$.

Thatcher, L.L., Janzer, V.J., and Edwards, K.W., 1977, Methods for determination of radioactive substances in water and fluvial sediment: U.S. Geological Survey Techniques of Water-Resources Investigations, book 5 , chap. A5, 95 p.

Thompson-Eagle, E.T., and Frankenberger, W.T., Jr., 1992, Bioremediation of soils contaminated with selenium, in Lal, R., and Stewart, B.A., eds., Advances in soil science: New York, Springer-Verlag, v. 17, p. 261-310.

Tidball, R.R., Severson, R.C., Gent, C.A., and Riddle, G.O., 1989, Element associations in soils of the San Joaquin Valley of California, in Jacobs, L.W., ed., Selenium in agriculture and the environment: Soil Science Society of America Special Publication 23, p. 179-193.

Trelease, S.F., and Beath, O.A., 1949, Selenium-Its geological occurrence and its biological effects in relation to botany, chemistry, agriculture, nutrition, and medicine: Burlington, Vt., The Champlain Publishers, 292 p.
Tweto, Ogden, Steven, T.A., Hail, W.J., Jr., and Moench, R.H., 1976, Preliminary geologic map of the Montrose $1^{\circ}$ by $2^{\circ}$ quadrangle, southwestern Colorado: U.S. Geological Survey Miscellaneous Field Studies Map MF-761, scale 1:250,000 (reprinted).

U.S. Department of Energy, 1986, Remedial actions at the former Climax Uranium Company uranium mill site, Grand Junction, Mesa County, Colorado-Final environmental impact statement: U.S. Department of Energy Report DOE/EIS-126-F, 2 volumes and appendices.

U.S. Environmental Protection Agency, 1980, Ambient water quality criteria for toxaphene: U.S. Environmental Protection Agency Report 440/5-80-076, $113 \mathrm{p}$. 1986, Quality criteria for water, 1986: U.S. Environmental Protection Agency Report EPA-440/5-86-001, 501 p.

1987, Ambient water quality criteria for selenium, 1987: Washington, D.C., 39 p.

U.S. Fish and Wildlife Service, 1986, Field operations manual for resource contamination assessment: Washington, D.C., variously paged.

-1990, Patuxent analytical control facility reference manual: Laurel, Md., U.S. Fish and Wildlife Service, variously paged.

Ward, J.R., and Harr, C.A., eds., 1990, Methods for collection and processing of surface-water and bedmaterial samples for physical and chemical analyses: U.S. Geological Survey Open-File Report 90-140, $71 \mathrm{p}$.

Weber, C.I., Peltier, W.H., Norberg-King, T.J., Horning, W.B., II, Kessler, F.A., Menkedrick, J.R., Neiheisel, T.W., Lewis, P.A., Klemm, D.J., Pickering, Q.H., Robinson, E.L., Lazorchak, J.M., Wymer, L.J., and Freyberg, R.W., 1989, Shortterm methods for estimating the chronic toxicity of effluents and receiving waters to freshwater organisms (2nd ed.): U.S. Environmental Protection Agency Report EPA/600/4-89/001.

Weres, O., Jaouni, A.R., and Tsao, L., 1989, The distribution, speciation, and geochemical cycling of selenium in a sedimentary environment, Kesterson Reservoir, California, USA: Applied Geochemisiry, v. 4, p. 543-563.

Wershaw, R.L., Fishman, M.J., Grabbe, R.R., and Lowe, L.E., eds., 1987, Methods for the determination of organic substances in water and fluvial sediments: U.S. Geological Survey Techniques of Water-Resources Investigations, book 5, chap. A3, $80 \mathrm{p}$. 
White, A.F., Benson, S.M., Yee, A.W., Wollenberg, H.J., Jr., and Flexser, Steven, 1991, Groundwater contamination at the Kesterson Reservoir, California-2. Geochemical parameters influencing selenium mobility: Water Resources Research, v. 27, no. 6, p. 1085-1098.

Whittig, L.D., Deyo, A.E., and Tanji, K.K., 1982, Evaporite mineral species in Mancos Shale and salt effloresence, Upper Colorado River Basin: Soil Science Society of America Journal, v. 46, no. 3, p. 645-651.

Whittig, L.D., Tanji, K.K., Biggar, J.W., Evangelou, V.P., and Deyo, A.E., 1983, Salinity investigations in the West Salt Creek watershed, Colorado: Davis, University of California, California Water Resources Center Completion Report, 160 p.

Williams, P.L., comp., 1964, Geology, structure, and uranium deposits of the Moab quadrangle, Colorado and Utah: U.S. Geological Survey Miscellaneous Geologic Investigations Map I-360, 2 sheets, scale $1: 250,000$.

Wilson, S.A., Kane, J.A., Crock, J.G., and Hatfield, D.B., 1987, Chemical methods of separation for optical emission, atomic absorption spectrometry, and colorimetry, chap. D of Baedecker, P.A., ed., Methods for geochemical analysis: U.S. Geological Survey Bulletin 1770, p. D1-D14.
Wright, W.G., 1994, Oxidation and mobilization of selenium by nitrate-A preliminary evaluation [abs.], in Marston, R.A., and Hasfurther, V.R., eds., Effects of human-induced changes on hydrologic systems: American Water Resources Association, summer symposium, Jackson, Wyoming, Proceedings, p. 1070.

Wright, W.G., 1995, Nitrogen fertilizer as an oxidizing agent to mobilize trace constituents from soil: American Water Resources Association, summer symposium, Honolulu, Hawaii, p. 483-490.

Wright, W.G., and Butler, D.L., 1993, Distribution and mobilization of dissolved selenium in ground water of the irrigated Grand and Uncompahgre Valleys, western Colorado, in Allen, R.G., and Neale, C.M.U., eds., Management of irrigation and drainage systems-integrated perspectives: American Society of Civil Engineers, New York, p. 770-777.

Wright, W.G., and McMahon, P.B., 1994, The effects of nitrate on the oxidation and mobilization of selenium, in American Geophysical Union abstract supplement, 1994 spring meeting, Baltimore, Maryland, p. 158. 